\title{
Série Educar
}

\section{Formação Docente}

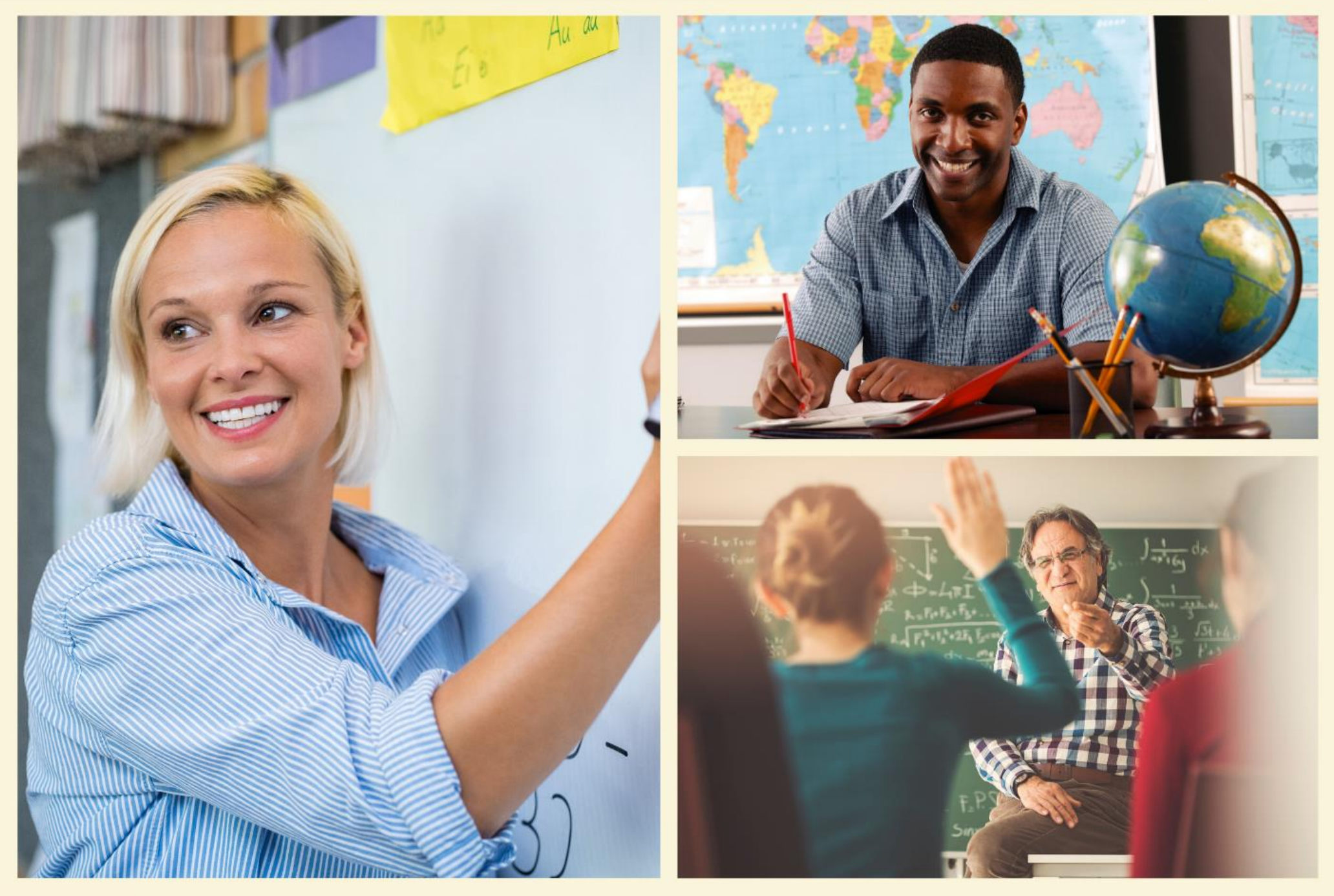

Editora Poisson

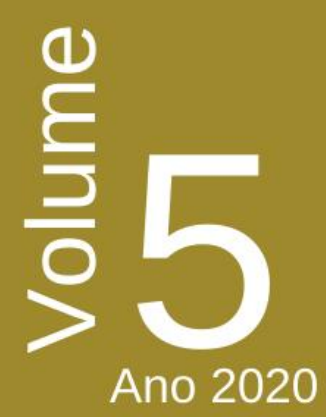


Editora Poisson

(organizadora)

\section{Série Educar - Volume 5 \\ Formação Docente}

1a Edição

Belo Horizonte

Poisson

2020 
Editor Chefe: Dr. Darly Fernando Andrade

\section{Conselho Editorial}

Dr. Antônio Artur de Souza - Universidade Federal de Minas Gerais

Ms. Davilson Eduardo Andrade

Dra. Elizângela de Jesus Oliveira - Universidade Federal do Amazonas

Msc. Fabiane dos Santos

Dr. José Eduardo Ferreira Lopes - Universidade Federal de Uberlândia

Dr. Otaviano Francisco Neves - Pontifícia Universidade Católica de Minas Gerais

Dr. Luiz Cláudio de Lima - Universidade FUMEC

Dr. Nelson Ferreira Filho - Faculdades Kennedy

Ms. Valdiney Alves de Oliveira - Universidade Federal de Uberlândia

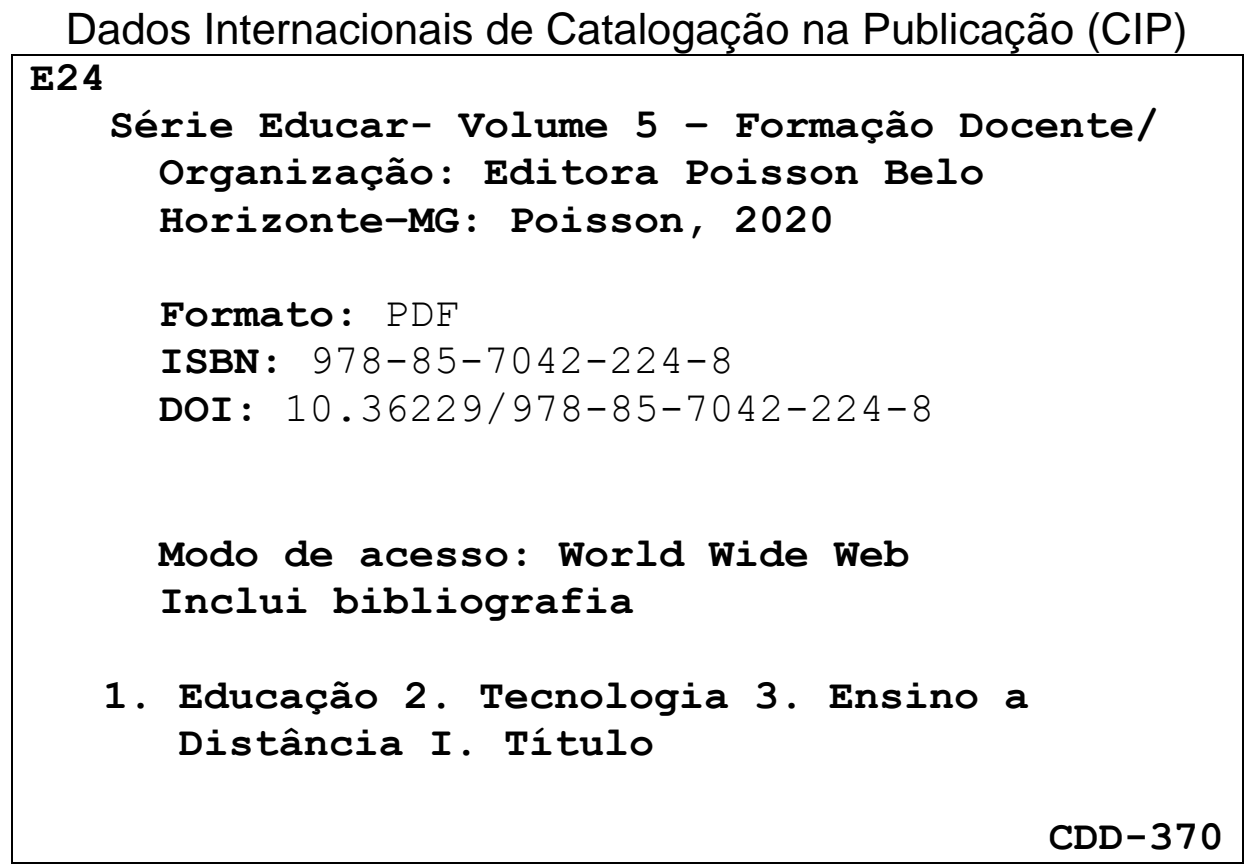

O conteúdo dos artigos e seus dados em sua forma, correção e confiabilidade são de responsabilidade exclusiva dos seus respectivos autores

www.poisson.com.br

contato@poisson.com.br 


\section{SUMÁRIO}

Capítulo 1: Currículo integrado no curso de Pedagogia 07

Luzia Alves de Carvalho, Talita da Silva Ernesto

DOI: 10.36229/978-85-7042-224-8.CAP.01

Capítulo 2: Perfil social e percepções discentes acerca da profissão de pedagogo: Quem são os ingressantes em Pedagogia? 15

Daniel Pinheiro Caetano Damasceno

DOI: 10.36229/978-85-7042-224-8.CAP.02

Capítulo 3: Saberes docentes na formação inicial do pedagogo: Um olhar sobre o PPP do Curso de Pedagogia da UFPI

Poliana Alves dos Santos, Antônia Dalva França Carvalho

DOI: 10.36229/978-85-7042-224-8.CAP.03

Capítulo 4: A atividade docente de professores estagiários: 0 que a autoconfrontação tem a revelar 32

Wescley Batista Lopes, Luciana Peixoto Bessa, Elisandra Maria Magalhães, Rozania Maria Alves de Moraes DOI: 10.36229/978-85-7042-224-8.CAP.04

Capítulo 5: 0 estágio supervisionado no Ensino Fundamental I: Uma prática necessária 40

Ingrid Vasconcelos Ferreira, Maria das Graças Pereira Soares

DOI: $10.36229 / 978-85-7042-224-8 . C A P .05$

Capítulo 6: Contribuição da residência pedagógica para a formação inicial de professores

Cicera Simone Santos de Farias, Nataliana dos Santos Oliveira, Eugênia Cruz Pinheiro, Josefa Nunes Pinheiro, Carlos Leonel de Alencar

DOI: $10.36229 / 978-85-7042-224-8 . C A P .06$

Capítulo 7: (Trans)formação docente: Programa residência pedagógica na formação inicial de professores

Bianca Bezerra Leandro, Ana Mercia Dantas de Oliveira Felix, Francisca Eliane da Rocha, Paula Ivani Medeiros dos Santos

DOI: $10.36229 / 978-85-7042-224-8 . C A P .07$

Capítulo 8: Limites do atendimento educacional especializado na Escola Pública e as contribuições do PIBID em sala de aula.

Fernanda Letícia Sousa Lima, Alane Delmondes Nóbrega, Tânia Serra Azul Machado Bezerra DOI: $10.36229 / 978-85-7042-224-8 . C A P .08$ 


\section{SUMÁRIO}

Capítulo 9: O Programa de Capacitação Docente do Instituto Chapada de Educação e Pesquisa (ICEP) e suas implicações na formação leitora dos alunos do sexto ano no Município Baiano de Xique-Xique 66

Jaklane Nunes Rabêlo

DOI: $10.36229 / 978-85-7042-224-8 . C A P .09$

Capítulo 10: Fatores associados à ansiedade: 0 que expressam alunos de um curso de licenciatura em Ciências Biológicas 74

Lucas de Pádua da Silva Maia, Vinícius Carvalho Pereira, Andreza Alencar Colares Botêlho, Jeanne Barros Leal de Pontes Medeiros

DOI: $10.36229 / 978-85-7042-224-8 . C A P .10$

Capítulo 11: Investigação da inclusão de Questões de Gênero na formação de Professores de Química 83

Ana Patricia Farias Borges, Paulo Alves Xavier da Silva, Maria do Socorro Tavares Cavalcante DOI: $10.36229 / 978-85-7042-224-8 . C A P .11$

Capítulo 12: Pensamento e ação do corpo na educação e formação de professores.. 89 Alice Maria Corrêa Medina

DOI: $10.36229 / 978-85-7042-224-8 . C A P .12$

Capítulo 13: Mapeando o corpo humano - sistemas: Da formação continuada para a sala de aula. 98

Dilma Nazaré dos Anjos Silva da Fonseca, Evanilda Figueiredo Gonçalves da Silva, Ana Lúcia Barros de Andrade, Lucilene Pacheco Santos

DOI: $10.36229 / 978-85-7042-224-8 . C A P .13$

Capítulo 14: A Legislação Brasileira e a formação continuada dos professores: Teoria e prática. 105

Farbênia Kátia Santos de Moura

DOI: 10.36229/978-85-7042-224-8.CAP.14

Capítulo 15: Formação continuada de professores: Um investimento necessário .....113 Adriétt de Luna Silvino Marinho, Tamires Cristina Ribeiro Silva DOI: 10.36229/978-85-7042-224-8.CAP.15 


\section{SUMÁRIO}

Capítulo 16: Formação de professores e as Leis 10639/03 e 11.645/08: A concepção societária e o fazer didático. 120

Eliana Carmem da Silva

DOI: $10.36229 / 978-85-7042-224-8 . C A P .16$

Capítulo 17: Plano Nacional de Educação: Uma análise sobre as metas para os programas de formação inicial e continuada para professores em exercício da Educação Básica 128

Ana Maria Freitas Dias Lima, Josseane Araújo da Silva Santos, Lilian Gama da Silva Póvoa, Maria José de Pinho

DOI: $10.36229 / 978-85-7042-224-8 . C A P .17$

Capítulo 18: 0 programa formar e suas implicações na Educação Básica Brasileira.136 Cristina Maria Bezerra de Oliveira, Scheiler Fagundes Carvalho, Wellyngton Chaves Monteiro da Silva DOI: 10.36229/978-85-7042-224-8.CAP.18

Autores: 142 


\section{Capítulo 1}

\section{Currículo integrado no curso de Pedagogia}

\section{Luzia Alves de Carvalho \\ Talita da Silva Ernesto}

Resumo: 0 artigo retrata uma nova concepção de processo ensino-aprendizagem a partir de um projeto de "currículo integrado" vivenciado em um curso de Pedagogia, com 25 alunas, do $1^{\underline{0}}$ período de 2019.1 e 8 docentes. Foi estruturado conjuntamente pela coordenadora e professoras, como "projeto integrado", capaz de articular os conteúdos das diversas disciplinas com um eixo-temático e metodologias ativas: "Adaptação de crianças" de creche e educação infantil, nos primeiros contatos com a escola. Teve como objetivo principal organizar e vivenciar um processo pedagógico que substitua 0 pensamento que isola pelo pensamento que unifica, articula, integra, o pensamento disjuntivo e redutor pelo pensamento complexo. Nesse sentido, novas perspectivas vêm se desenhando em vista de uma formação de professoras que articulem e vivenciem conhecimentos e competências profissionais mais adequadas à Educação hoje. Resultados: maior participação das alunas e integração do corpo docente; olhar mais global do fenômeno "Adaptação de crianças da creche e Educação Infantil", visto a partir de diferentes enfoques; interdisciplinaridade como elemento enriquecedor do processo ensino-aprendizagem; substituição das aulas expositivas pelo protagonismo das alunas; aprendizagem holística, significativa, prazerosa, não fragmentada, mas unificada e integrada; inovação como elemento desafiador; ricas experiências de trabalho coletivo; salto qualitativo para o Curso de Pedagogia em termos de inovação. Adotou-se como metodologia a pesquisa qualitativa, para coleta e tratamento dos dados, porque possibilita a compreensão da conduta humana e da prática docente a partir do próprio autor e sua prática. Foram utilizadas técnicas como observação participante, entrevistas, portfólio e fóruns.

Palavras-chave: Currículo Integrado, Metodologias ativas, Formação Docente, Inovação Educacional. 


\section{INTRODUÇÃO}

0 curso de Pedagogia do ISECENSA, Campos dos Goytacazes - RJ, destina-se à formação de professores para exercer funções de Magistério na Educação infantil e nos anos iniciais do Ensino fundamental, disciplinas pedagógicas do ensino médio, além do exercício de funções da Educação profissional, na área de serviços e apoio escolar em outras áreas, nas quais sejam previstos conhecimentos pedagógicos para atividades escolares e não escolares (PPC, 2017). Concebe a educação como um processo complexo, interdisciplinar, e que não se realiza sem transitar os saberes, pois a realidade não é somente multidimensional, mas também multirreferencial, permitindo estabelecer vínculos entre as pessoas, fatos, campos de conhecimentos e ações cotidianas (BEHRENS, 2006).

Compreende-se, que toda mudança pressupõe substituir o pensamento que separa e isola, por um pensamento que une e distingue, o pensamento disjuntivo e redutor pelo pensamento complexo. (MORIN, 2000). Neste sentido, novas perspectivas vêm se desenhando para uma formação de professores, que articulem conhecimentos educacionais com práticas profissionais e de pesquisas mais integradas.

Para atingir essas finalidades, o Curso prioriza na formação do pedagogo, o conhecimento da escola como organização complexa que tem a função social e formativa de promover educação de qualidade, pluralidade de saberes e conhecimentos, conexão entre a formação inicial, o exercício da profissão e as exigências da formação continuada. Compreende que a realidade complexa do mundo atual exige formas de análise mais coerentes e mais adequadas à realidade; valoriza o paradigma da complexidade, abraçando a interdisciplinaridade e a transdisciplinaridade (MORIN, 2012), possibilitando a superação da dissociação das experiências acadêmicas entre si e com a realidade social. A partir destas considerações pensou-se em construir e vivenciar um projeto de Currículo Integrado "para" e "com" as alunas do curso de Pedagogia 2019.2, em vista de uma formação adequada a essas prioridades.

\subsection{BJETIVOS E METODOLOGIA}

Os objetivos visam 1) investigar e avaliar o projeto de "currículo integrado" na formação de docentes e alunas do Curso de Pedagogia; 2) organizar o currículo a partir de um eixo integrador, a ser trabalhado com metodologias ativas; 3 ) oportunizar às alunas situações para escolha, criatividade, protagonismo, desenvolvimento do espírito crítico; 4) detectar possível avanço na construção da identidade institucional coletiva das docentes.

Para atender a esses objetivos adotou-se a pesquisa qualitativa interpretativa como paradigma de ação. A construção da identidade coletiva, na formação de professoras é uma realidade complexa, dinâmica multifatorial, possível de ser construída e captada por um processo de interpretação qualitativa fugindo dos modelos quantitativos mais adaptados às ciências exatas, sem contudo desconsiderá-las. (CARVALHO, 2009)

A natureza do nosso objeto de investigação levou-nos a optar, pelo paradigma qualitativo-etnográfico, ancorando-nos em Ludke e André (1986), Miguel Valles (2003) e Thiollent (2000). 0 enfoque qualitativo possibilita a compreensão da conduta humana a partir do próprio ator e da própria prática, servindo-se da observação participante, de entrevistas e técnicas qualitativas.

0 universo da pesquisa foi constituído por 8 docentes do $1^{\text {o }}$ período do Curso de Pedagogia e 25 alunas, ao longo de 2019. Este estudo constituirá um passo significativo na inovação do curso de Pedagogia. Espera-se que, no decorrer do processo, docentes e discentes vivenciem ricas experiências de trabalho coletivo com o planejamento, execução e avaliação de currículo integrado por eixos temáticos, tornando-se pessoas ativas, críticas, protagonistas de suas aprendizagens, construtoras de um saber global, que lhes permita assimilar os conteúdos em sua complexidade de modo unitário e articulado.

\section{DESENVOLVIMENTO}

Segundo o PPC (2017) do referido curso, o currículo dispõe os conteúdos em áreas ou núcleos interdisciplinares buscando uma visão orgânica desses conteúdos e o diálogo entre as áreas do saber. Oferece três núcleos disciplinares: Estudos Básicos, Aprofundamento e Diversificação dos estudos, cada um deles agregando disciplinas afins, o que garante integração dos diversos componentes curriculares e o entrelaçamento teoria-prática. 
A partir dessa concepção inicial do Curso, de sua epistemologia, de seus princípios didáticometodológicos, pensou-se em retomar a formação de professores a partir da inovação de suas práticas. Para isso, pensou-se em um projeto de reformulação do currículo, integrando as disciplinas por um eixo temático, conforme assinalamos nos objetivos. A dinâmica do projeto pressupõe que o conteúdo de cada disciplina, mantenha diálogo permanente com outros conteúdos, utilizando práticas do ensino híbrido e metodologias ativas. Assim, cada disciplina oferecerá sua contribuição para a compreensão do tema integrador, em termos de enfoque, métodos, procedimentos e conceitualizações.

0 que se busca é a retomada da proposta pedagógica do curso para atualizá-lo segundo os desafios da formação de educadores, para atuarem conforme as Diretrizes da BNCC (2017) e responder às mudanças que a revolução digital impõe. A imersão nas metodologias ativas e nos ambientes virtuais de aprendizagem (AVA) vem subsidiar o processo, constituindo-se em um dos maiores desafios à profissionalidade docente e à gestão pedagógica em sala de aula.

\subsection{CURRÍCULO INTEGRADO: DESAFIO À FORMAÇÃO DE EDUCADORES HOJE}

A educação inovadora é o grande desafio para a formação de educadores competentes e antenados com as exigências da atualidade. Neste contexto, MORIN (2000) destaca que a Educação deve favorecer a aptidão natural da mente para formular e resolver problemas, integrar saberes, despertar a curiosidade, o espírito crítico, a capacidade de analisar, relacionar fatos, princípios e argumentar com lógica. Contudo, percebemos que os conteúdos curriculares hoje, ainda são organizados segundo a lógica disciplinar e teorizam as disciplinas escolares em relação direta com as disciplinas escolares acadêmicas e científicas.

Tomar as disciplinas escolares como fontes para o conteúdo curricular é uma postura que vem sendo criticada, por não atender às finalidades educacionais relativas a questões políticas, mais amplas. Exige-se, portanto, reconceptualização do campo. Veiga Neto (2002) considera que a organização disciplinar é uma estrutura disciplinadora, em que os saberes são hierarquizados e classificados com fronteiras delimitadas.

Segundo a concepção crítica deseja-se que a organização curricular valorize tanto as atividades, quanto as culturais numa simbiose enriquecedora capaz de promover experiências significativas de conhecimentos, atitudes e apreciações, para melhor inserção dos alunos na realidade social de maneira autônoma, consciente, responsável e solidária. Isso é possibilitado pela interdisciplinaridade, que não é simples justaposição de disciplinas, nem diluição delas numa generalidade sem sentido. Implica em integração de conteúdos, para que professores e alunos pensem, compreendam, expliquem, planejem estratégias para abordar determinados fatos, problemas e desafios da realidade que os cerca. Para Bochniak (1992), a interdisciplinaridade permite ao aluno relacionar fatos e conceitos, entender e lincar conteúdos de diferentes áreas, unindo-as para resolver problemas e construir o novo.

A partir dessas considerações, entende-se o "Currículo integrado" como uma estratégia de ensino aprendizagem que articula conteúdos, habilidades e competências, como um todo, em vista da aquisição de uma visão global e unificada dos conteúdos escolares, geradores de um saber novo, que implica os princípios da interdisciplinaridade e transdisciplinaridade dos conteúdos, garantindo a interface entre as disciplinas.

Inovando seu Curso de Pedagogia o ISECENSA busca adequar-se às mudanças espácio-temporais, para possibilitar às alunas serem protagonistas do seu processo de formação docente. Almeja-se um currículo flexível, aderente aos tempos atuais, pois não existe cultura nem uma sociedade homogêneas, unitárias em seus princípios e aceita por todos. A cultura é um plano de luta em que as reformas curriculares acontecem para questionar o presente em seus pontos centrais.

O novo paradigma impulsionará docentes e discentes, a adquirem asas e alçarem voos muito além da abordagem isolada dos conteúdos escolares, sem nada acrescentar às vivências cotidianas dos alunos. As metodologias ativas (CASTELLAR, 2016; BACICH, 2018) assumidas, como pano de fundo e recursos didáticos no currículo integrado, abriram espaços para um ensino aprendizagem mais significativo com alunos protagonistas e atores do próprio processo de aprender. Bastos (2006) conceitua metodologia ativa como processo de conhecimento, estudo e pesquisa por meio da tomada de decisões individuais ou coletivas para resolução de problemas na ação de ensinar e aprender (ANASTASIOU; ALVES, 2005). Adotálas é um grande desafio, considerando que, para sua implementação, é preciso uma mudança cultural com a incorporação de novos hábitos e maneiras de fazer a prática pedagógica acontecer. 


\section{RESULTADOS E DISCUSSÃO}

No decorrer do semestre, aconteceram sete reuniões sobre integração curricular, metodologias ativas, estratégias pedagógicas, aparatos tecnológicos, estruturação, reestruturação dos conteúdos e esclarecimento de dúvidas pertinentes aos processos. Em conjunto optou-se pelo uso de Ambientes Virtuais de Aprendizagem (AVA) como o Schoology, a plataforma Padlet, o polleverywhere (HORN, 2015). As interações e trocas entre os professores facilitaram a personalização e individualização na construção dos conhecimentos pelas alunas. Nas primeiras aulas o projeto foi apresentado e discutido com as alunas que o perceberam como inovação, sabendo que exigiria delas mais participação e integração. Houve dificuldade de realizar a desejada integração por algumas docentes, seja pela natureza dos conteúdos, como também por resistência e não familiaridade com tal prática.

As aulas aconteciam em diferentes espaços: sala de aula, biblioteca, sala de artes, MakerSpace e Laboratório de Informática. 0 eixo temático "Adaptação das crianças nos primeiros dias na Educação Infantil" integrou todas as disciplinas do curso sob o viés das metodologias ativas, conforme o organograma abaixo:

Figura 02 - Organograma da integração curricular no 1o Período do curso de Pedagogia

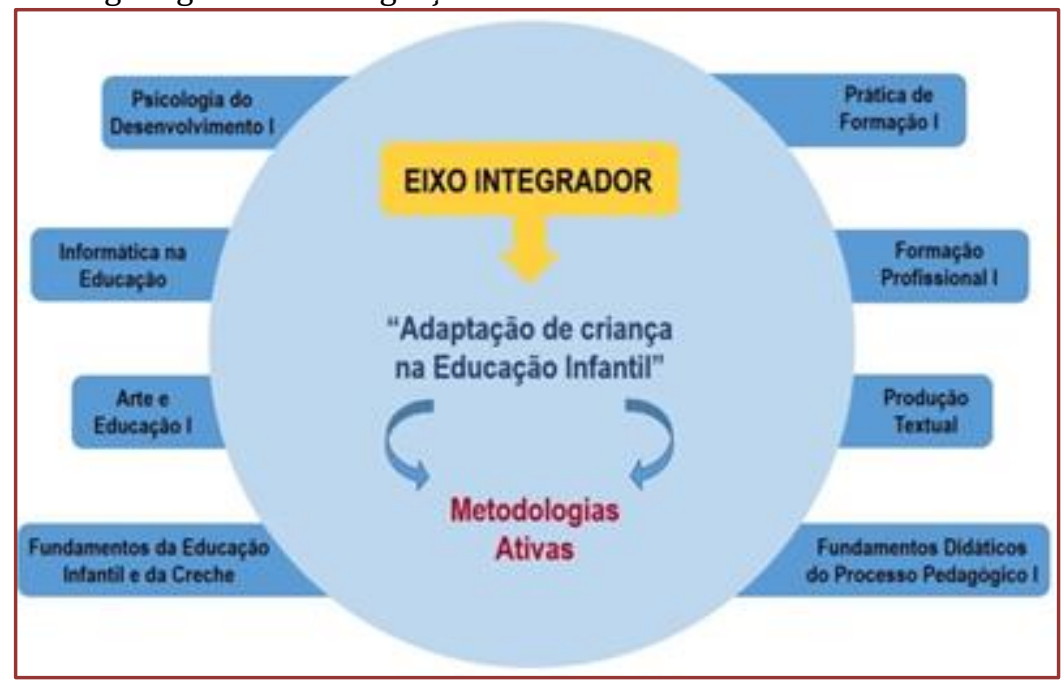

Para análise e discussão dos dados optou-se por retomar a narração quase textual de cada professora sobre o modo como vivenciar a integração em sala de aula, sem secundarizar os conteúdos de suas disciplinas. As disciplinas do Curso foram trabalhadas em sua inteireza, como totalidade, inseridas no contexto real de estágio em que as alunas se inserem no 1ํㅜ período (creche e pré-escola).

A professora da disciplina de "Fundamentos Didáticos I" trabalhou o tema integrador partindo das contribuições dos autores estudados, com o objetivo de analisar as contribuições da disciplina no processo de integração da criança na Educação Infantil. Utilizou-se para isso, textos como Adaptação na escola; Doze dicas para passar pelo processo; As 10 dúvidas sobre adaptação na Educação Infantil; Adaptação e Choro na escola e vídeos afins. 0 estudo da Didática e seus precursores foi introduzido, a partir da aprendizagem baseada em problemas (PBL): " Como acontece o processo de adaptação na Educação Infantil? ". Questionou também sobre como as teorias dos precursores da didática contribuem para o processo de adaptação da criança na escola infantil.

No estágio realizado na educação infantil, as alunas observaram a realidade e trouxeram para a sala de aula os problemas evidenciados. Socializaram suas observações com exemplos que foram discutidos à luz dos teóricos estudados. Com a aula invertida, realizaram pesquisas anteriores no AVA "Schoology", e participaram de um fórum demonstrando suas compreensões sobre o tema. Desenhos, versos, apresentações foram marcantes no desenvolvimento do projeto. 
Como atividade, um grupo encenou a relação da professora com a chegada da criança na escola destacando a afetividade como essencial no processo de adaptação das crianças. Outro grupo criou uma esquete com palitoches sobre os conteúdos estudados. Um terceiro grupo fez um jogral articulando teorias da Didática com a prática pedagógica na educação infantil. Uma aluna declamou uma poesia articulando teorias dos precursores com a chegada da criança à escola nos primeiros dias de aula. Estas interações aconteciam como entremeio do conteúdo normal das disciplinas. Elas permitem ao discente relacionar fatos, conceitos e lincar conteúdos de diferentes áreas, vivenciando a interdisciplinaridade destacada por Bochniak (1992).

Na disciplina "Informática na Educação", foram trabalhados os conteúdos com recursos do Word, Excel, Power Point, Internet a partir de situações-problema: Como preparar uma atividade para alunos da creche? Como fazer uma planilha de notas anuais e tirar a média dos alunos? Como fazer uma apresentação em power point para os pais dos alunos? As ferramentas foram trabalhadas de modo integrado com o tema gerador, no laboratório de informática. As alunas perceberam a utilidade da informática em uma situação pratica: seu uso no cotidiano para resolver problemas. Bacich (2018) corrobora o trabalho da professora ao destacar que a aprendizagem por problema sintoniza com a proposta interdisciplinar do currículo integrado.

A disciplina "Produção Textual" ministrada pela mesma professora trabalhou conteúdos sobre coesão e coerência, intertextualidade e polifonia, gêneros e tipologias textuais, discurso direto e indireto, argumentação, discurso dissertação de caráter científico, a partir de textos de jornais e revistas, artigos, textos literários e vídeos que abordavam direta ou indiretamente o eixo norteador do projeto. Os procedimentos metodológicos pautaram-se em atividades que permitiram o domínio dos conceitos básicos estudados com enfoque no eixo norteador, a partir de contextos híbridos: Sala de aula invertida, fóruns, rotação por estações, paleta de cores com uso de artigo científico; Instrução por pares (para análise de algumas produções textuais); Storytelling (posterior construção do artigo científico que abordasse o tema creche e adaptação das crianças (BACICH; NETO; TREVISANI, 2015); (BACICH e MORAN, 2018).

A disciplina "Psicologia do Desenvolvimento I" contribuiu para o desenvolvimento da capacidade de analisar-se, selecionar fatos e princípios, argumentar com lógica (MORIN, 2000). A professora trabalhou o conteúdo adaptação escolar, a partir dos estágios de desenvolvimento de Piaget. Utilizou como recurso a rotação por estações, destacando a noção de objeto permanente, tema fundamental na educação infantil. Ao longo das aulas, eram selecionados textos que abordavam a função do professor no processo de adaptação com estratégias pedagógicas que poderiam auxiliar nesse processo, como relato e discussão de casos levantados pelas alunas a partir dos estágios. Foram utilizados textos dispostos no Schoology, subsidiando a aula invertida e também o modelo de rotações para o estudo dos conteúdos. Videoaula fez parte do processo, após o qual, as alunas foram convidadas a produzirem seu próprio vídeo estabelecendo relação entre o conteúdo estudado e o processo de adaptação da criança na escola infantil. Nos estágios, as alunas relacionaram a teoria de Piaget com o observado em sala de aula. A professora utilizou ainda a gamificação com utilização de Software para quizzes, como o Socrative e o Kahoot. Com estas estratégias foram feitas as avaliações processuais. O Brainstorming mediado pelo software Mentimeter permitiu o uso de celular, dispositivo móvel, popularizado pelo BYOD - Bring Your Own Device (LUGO e SCHURMANN, 2012). Peer Instruction (aprendizagem entre pares) foi utilizada em diversas práticas ao longo do semestre. Desse modo, a professora levou a classe à visão unificada dos conteúdos escolares, gerando um novo saber engendrado no processo (BEHRENS, 2006), integrado ao eixo temático e metodologias ativas.

Em sua ementa, a "disciplina Fundamentos da Educação Infantil” abordou temas diretamente ligados ao eixo integrador: A infância e seus fundamentos, os teóricos contribuintes da educação infantil, educação infantil e as novas definições segundo a BNCC, aspectos chave de uma Educação Infantil de qualidade, e ainda a rotina na educação infantil, os critérios para atendimento da criança em idade de creche e a dimensão lúdica da criança. A partir de aula invertida, a rotação por estações e a plataforma Schoology, as alunas buscaram soluções para os diferentes casos e situações de adaptação da criança na escola. A disciplina, com conteúdos essencialmente voltados para creche e educação infantil, vivenciou o projeto de modo especial, pois traz como essência o eixo integrador. Esse é assumido por todas as docentes, cada uma a partir de seu enfoque específico. Adotar essa prática é desafio, visto que é preciso uma mudança estrutural e conversão digital, à medida que se propõe um aprendizado centrado nas alunas, visibilizando a identificação de suas necessidades reais de aprendizagem (BACICH; MORAN, 2018). 
A disciplina de "Prática de Formação" correlacionou conhecimentos formais, científicos com o saber-fazer advindo das tarefas cotidianas em Creches, formalizando uma prática reflexiva sistemática e internalizada. A professora utilizou a aula invertida com o Schoology, charges e fóruns. As alunas foram agrupadas de acordo com suas habilidades e conhecimentos para aprofundarem temas e práticas do dia a dia na Creche e a influência das figuras de apego e dos objetos transicionais nesse processo, suas percepções e experiências do estágio ou do próprio trabalho. A Gamificação foi explorada através de dinâmicas com questões-desafio sobre o vínculo educador/família. A avaliação Integrada permitiu a interdisciplinaridade como princípio fundamental da proposta do curso. Foram construídos brinquedos pedagógicos que favorecem o processo de adaptação escolar das crianças em idade de 0 a 3 anos, considerando as necessidades desta faixa etária: desenvolver a coordenação visomotora e a percepção sensorial, a manipulação e a coordenação dos movimentos. As alunas construíram brinquedos sonorizados para potencializar a capacidade de interação entre as crianças, blocos de encaixe, brinquedos de puxar e empurrar para ajudar no desenvolvimento da noção espacial.

Este projeto de integração disciplinar com o uso de metodologias ativas, possibilitou a aprendizagem personalizada com tecnologias contemporâneas, são veículos de comunicação e expressão em ambientes de aprendizagem que desenvolvem a autonomia e outras competências fundamentais para as alunasmestras atuarem em seu campo de trabalho (BACICH, MORAN, 2018).

Percebeu-se que a disciplina "Formação Profissional I", diretamente relacionada com Práticas de Formação I trabalhou conteúdos como formação docente, profissionais da educação infantil (creche) e seus desafios, relações entre o cuidar e educar, rotina da creche e sua organização a partir de textos, artigos, vídeos que abordaram o eixo norteador "adaptação escolar da criança na creche". Os procedimentos metodológicos pautaram-se em atividades que permitiram o domínio de abordagens teóricas em harmonia com a disciplina de Prática de Formação ministrada por outra professora e demais disciplinas do $1^{\text {o }}$ período, a partir do eixo norteador. Esta disciplina articula-se com as demais a partir de seus aportes, levados em conta nas discussões e fóruns, cujo objetivo era iluminar e fundamentar o processo de compreensão da adaptação escolar de crianças na educação infantil.

Em seus relatos o professor de "Arte Educação I" trabalhou os conceitos de cronologia artística como ferramenta atrativa para a acolhida em sala de aula, além de técnicas de desenho e pintura, teatro e Net Art, como elementos facilitadores à adaptação de novos alunos da educação infantil. Durante o estágio as alunas fotografaram crianças em momentos significativos da adaptação escolar. Essas fotografias foram apresentadas e discutidas em sala de aula. Sem perder o foco dos conteúdos de sua disciplina, o professor apresentou os trabalhos elaborados pelas alunas após tratamento de Net Art com o aplicativo GO ART. Expressionismo, fauvismo e surrealismo foram pano de fundo para as fotos. Autores como Sousa (2003), Reis (2003) e Vygotsky (1934), consideram que a educação pela arte contribui para o desenvolvimento em áreas sociais, emocionais, cognitivas, criatividade, imaginação. Neste sentido, procurou-se conhecer os diversos movimentos artísticos, relacioná-los com o tema integrado e compreender melhor a importância que a arte tem e como se relaciona com as outras áreas.

\section{CONSIDERAÇÕES FINAIS}

Os resultados obtidos decorreram da análise do portifólio e depoimentos de alunas e docentes. 0 currículo integrado por eixo temático foi considerado por todos como positivo e desafiador, exigindo estudos, pesquisas, planejamento conjunto, adaptações e interações grupais. Resultou em atitudes de maior participação, criatividade por parte das alunas, olhar mais globalizado do trabalho em sala de aula, apresentado sob diferentes perspectivas. A interdisciplinaridade e transdisciplinaridade foram sentidas e percebidas de modo enriquecedor, embaseadas pelos aportes teóricos dos autores estudados nas diversas disciplinas, fornecendo argumentos convincentes às discussões, fóruns e debates. 0 uso de diferentes metodologias ativas substituiu as aulas expositivas pelo protagonismo das alunas.

Percebeu-se o desempenho competente do corpo docente motivado e comprometido. A proposta de currículo integrado foi subsidiada por Tardif (2012) ao afirmar que a atividade docente não se exerce sobre um objeto, mas por uma rede de interações com outras pessoas, o que exigiu das docentes não somente um saber sobre objetos, mas a capacidade de atuarem como sujeitos em continuas comunicações. 
Constatou-se, ainda, que as experiências vivenciadas foram muito significativas, despertando maior dedicação ao estudo, tanto por parte das professoras, quanto pelas alunas, maior conhecimento sobre currículo integrado e interdisciplinaridade; maior integração do corpo docente, conhecimento sobre novas tecnologias e sobre a adaptação das crianças na escola. Notou-se mais engajamento das alunas, mais prazer nas aulas e consequentemente, melhor rendimento nas avaliações semestrais.

Quanto à importância do currículo por projeto integrador, assim se expressou uma professora: "Vejo o projeto integrador como uma necessidade dos tempos atuais e uma resposta urgente a algumas demandas que o conhecimento compartilhado não é capaz de dar."

É importante destacar que a inovação curricular fez-se a partir do eixo temático e uso de metodologias ativas. Professoras e alunas puderam internalizar um modo novo de ser professoras, uma postura proativa em sala de aula, como segundo a natureza. Não se é "bom professor" se não se sabe chegar aos alunos e considerá-lo sujeito de seu processo como pessoa e profissional qualificado.

Nóvoa (2009) sugere a necessidade do profissional docente refletir sobre sua prática, que procure sempre aprender e aprender melhor. Nesse sentido, o currículo integrado coadjuvou o processo, no ínicio lentamente, mais sólido, capaz de promover a construção da identidade coletiva das professoras, a qual acenamos no ínicio desse relato. De fato, a formação do professor se faz sobretudo na prática coletiva.

0 currículo integrado possibilitou às professoras e alunas vivenciar ricas experiências de trabalhos coletivos, de planejamento, execução e avaliação de currículo integrado por eixos temáticos, ganho significativo na construção de novas experiências de aprendizagem. Elas serão capazes de levar à frente um ensino mais condizente com a realidade complexa de novos tempos, de múltiplas linguagens e desafios.

O currículo assim concebido é capaz de unificar os saberes, promover relações entre os conteúdos e as pessoas, numa simbiose rica de experiências de si, de conhecimentos, atitudes e crenças, possível de inserir os sujeitos pedagógicos na realidade de modo consciente, responsável e solidário (NÓVOA, 2009). Ao adotá-lo o curso de Pedagogia do ISECENSA dá um salto qualitativo em seu processo de inovação curricular e formação contínua de educadores proativos, empreendedores, gestores de nova visão e prática educacional qualificada.

\section{REFERÊNCIAS}

[1] Anastasiou, L. G. C.; Alves, L. P. (Org.). Processos de ensinagem na universidade: pressupostos para as estratégias de trabalho em aula. 5. ed. Joinville, SC: Univille, 2005.

[2] Bacich, Lilian; Tanzi Neto, Adolfo; Trevisani, Fernando de Mello (org). Ensino Híbrido: personalização e Tecnologia na Educação. Porto Alegre: Penso. 2015.

[3] Bacich, Moran. Metodologias ativas para uma educação inovadora: uma abordagem teórico-prática. Porto Alegre: Penso, 2018. 238 p.

[4] Bastos, C. C. Metodologias ativas. 2006. Disponível em: <http://educacaoemedicina.blogspot.com. br/2006/02/metodologias-ativas.html>. Acesso em: 25 jul. 2019.

[5] Behrens, Marilda Aparecida. Paradigma da complexidade: metodologia de projetos, contratos didáticos e portfólio. Petrópolis, RJ: Vozes, 2006.

[6] BNCC, Base Nacional Comum Curricular. MEC. Secretaria de Educação Básica, Brasília, 20 de Dezembro de 2017.

[7] Bochniak, Regina. Questionar o conhecimento-Interdisciplinaridade na escola. São Paulo: Loyola, 1992.

[8] Carvalho, Luzia Alves de (A. PRINCIP.). Identidade Institucional Coletiva em Tempos Líquidos : possibilidade ou ilusão?. 0. ed. Rio de Janeiro: Usina de Letras, 2009. 140 p. ISBN 978-85-62851-19-3.

[9] Castellar, Sonia M. Vanzella (org). Metodologias Ativas: introdução - 1. Ed. - São Paulo: FTD, 2016 a

[10] _ _ ensino por investigação - 1. Ed. - São Paulo: FTD, 2016 b

[11] _ _ grupos operativos - 1. Ed. - São Paulo: FTD, 2016. c

[12] ___ sequências didáticas - 1. Ed. - São Paulo: FTD, $2016 \mathrm{~d}$

[13] __ _ as diferenças linguagens imagéticas - São Paulo: FTD, 2016. e

[14] Horn, Michael B. (A. PRINCIP.). Blended: usando a inovação disruptiva para aprimorar a educação. Porto Alegre: PENSO, 2015. 292 p. 
[15] Lüdke, M.; André, M. Pesquisa em educação: abordagens qualitativas. São Paulo: EPU, 1986.

[16] Lugo, M. T.; Schurmann, S. (2012) Turning on mobile learning in Latin America: Illustrative initiatives and policy implications. Paris: UNESCO.

[17] Miguel Valles, M. Técnicas cualitativas de investigación social: reflexión metodológica y práctica profesional. 3 ed. Madrid: Síntesis, 2003.

[18] Morin, Edgar. Os sete saberes necessários à educação do futuro. São Paulo/Brasíla: Cortez/UNESCO, 2000.

[19] __ Os Sete Saberes Necessários A Educação Do Presente: Por uma Educação Transformadora. 1. ed. Rio de Janeiro: WAK, 2012. 268 p.

[20] Nóvoa, A. Professores: Imagens do futuro presente. Lisboa: Educa, 2009.

[21] PPC. Plano Pedagógico do curso. Pedagogia. Isecensa. 2017

[22] Reis, R. (2003). Educação pela Arte. Lisboa: Universidade Aberta

[23] Sousa, A. (2003). A Educação pela Arte e Arte na Educação, Bases Psicopedagógicas.1ํvolume. Lisboa: Instituto Piaget

[24] Tardif, M. Saberes docentes e formação profissional. Petrópolis. RJ: Vozes, 2002.

[25] Thiollent, M. Metodologia da pesquisa-ação. 10. Ed. São Paulo: Cortez, 2000.

[26] Veiga-Neto, Alfredo. De geometrias, currículo e diferenças. Educação e Sociedade, ano XXIII, n. 79, p.163-186, ago. 2002

[27] Vygotsky, L. (1934). Imaginação e Criatividade na Infância. Lisboa: Dina livro 


\section{Capítulo 2}

Perfil social e percepções discentes acerca da profissão de pedagogo: Quem são os ingressantes em Pedagogia?

\section{Daniel Pinheiro Caetano Damasceno}

Resumo: 0 presente artigo aborda a temática da formação do pedagogo e tem por objetivo construir o perfil socioeconômico e cultural dos estudantes do curso de Pedagogia da Universidade Estácio de Sá campus Campos dos Goytacazes - RJ e investigar suas percepções acerca da atuação profissional do Pedagogo. A metodologia utilizada foi quantitativa, com a construção de um questionário fechado com dezenove perguntas que construam o perfil dos discentes e suas percepções acerca do curso. A pesquisa foi realizada com os alunos da etapa inicial $\left(1^{\circ}, 2^{\circ}\right.$ e $3^{\circ}$ períodos $)$ do curso de Pedagogia da Universidade Estácio de Sá campus Campos dos Goytacazes totalizando uma população de 107 respondentes. Os resultados mostram que o curso de Pedagogia recebe alunos de classe popular, oriundos de famílias com pouco acesso à educação formal. Essa realidade aponta e reporta ao curso uma responsabilidade de transformação dessa clientela para a desafiadora tarefa da construção educacional de um país desigual

Palavras-Chave: Pedagogia; Pedagogo; Universidade Estácio de Sá; Percepções Discentes. 


\section{INTRODUÇÃO}

O Ensino Superior constitui segmento de importantes análises, planos e políticas públicas para a construção da sociedade e educação brasileira. O Plano Nacional de Educação (PNE) (2014-2024) aborda metas que dão protagonismo à Educação Superior: A meta 12 objetiva o alcance de $50 \%$ (taxa bruta) e $33 \%$ (taxa líquida) de matrículas da população de 18 a 24 anos; garantia da qualidade da oferta de Educação Superior e alcance de $40 \%$ dessa oferta em Universidades Públicas. O Censo da Educação Superior ${ }^{1}$ divulgado em 2017 pelo Ministério da Educação e Cultura (MEC) aponta mais de 8 milhões de pessoas no Brasil com acesso ao Ensino Superior, com $75 \%$ desse quantitativo em instituições privadas. Embora o percentual de oferta em Universidades Públicas pretendido pelo PNE ainda não tenha sido alcançado, os dados mostram que no último século houve uma explosão de matrículas no Ensino Superior, tendo crescido 268\% entre 1998 e $2014^{2}$ (ANDRES, 2017). Dentro desse contexto, o Curso de graduação em Pedagogia está entre os três mais procurados, com $8,6 \%$ da população total de universitários. Qual o perfil socioeconômico e cultural do graduando em Pedagogia? Quais as percepções desses estudantes sobre a prática profissional do Pedagogo? Essas são questões que a pesquisa, fomentada pelo Programa Pesquisa e Produtividade da Universidade Estácio de Sá, visa investigar.

O presente artigo tem por objetivo construir o perfil socioeconômico e cultural dos estudantes do curso de Pedagogia da Universidade Estácio de Sá campus Campos dos Goytacazes - RJ e investigar suas percepções acerca da atuação profissional do Pedagogo.

Para a realização da pesquisa foi utilizada a metodologia quantitativa, com a construção de um questionário fechado com dezenove perguntas que construam o perfil dos discentes e suas percepções acerca do curso. 0 questionário utilizado na pesquisa foi elaborado por este pesquisador e testado com os professores do curso de graduação em Pedagogia da Universidade Estácio de Sá campus Campos dos Goytacazes - RJ, em reuniões docentes. De acordo com Quivy \& Campenhoudt (2005, p. 188), o questionário enquanto instrumento de coleta de pesquisa possibilita:

colocar um conjunto de inquiridos, geralmente representativo de uma população, uma série de perguntas relativas à sua situação social, profissional ou familiar, às suas opiniões, à sua atitude em relação a opções, ou a questões humanas e sociais, às suas expectativas, ao seu nível de conhecimento ou de consciência de um acontecimento ou de um problema ou ainda sobre qualquer outro ponto que interesse os investigadores (QUIVY \& CAMPENHOUDT, 2003, p. 188)

De acordo com os autores em questão, o questionário é uma ferramenta metodológica adequada quando o objetivo do pesquisador é, entre outros, "o conhecimento de uma população enquanto tal, as suas condições e modos de vida, os seus comportamentos, os seus valores ou as suas opiniões" (p. 189). Dessa forma, para construir o perfil socioeconômico e cultural do público pesquisado, bem como suas percepções acerca da profissão, o questionário foi escolhido enquanto ferramenta de coleta de dados, uma vez que, seu emprego, possibilita, ainda conforme Quivy \& Campenhoudt (2003, p. 189), "quantificar uma multiplicidade de dados e de proceder, por conseguinte, a numerosas análises de correlação".

A pesquisa foi realizada com os alunos da etapa inicial (1ำ, $2^{\circ}$ e $3^{\circ}$ períodos) do curso de Pedagogia da Universidade Estácio de Sá campus Campos dos Goytacazes totalizando uma população de 107 respondentes. 0 recorte temporal se dá para capturar ainda a primeira impressão dos discentes acerca da profissão do pedagogo, sem que a trajetória em períodos mais avançados do curso tenham, a partir das bases teóricas discutidas em sala, construído uma nova - e técnica - percepção acerca do fazer profissional pedagógico, buscando, portanto, a captura de uma impressão inicial acerca do curso escolhido.

Com relação ao gênero dos ingressantes, 95\% declararam ser do sexo feminino, o que reforça um estereótipo da educação enquanto uma tarefa predominantemente feminina, seja no campo profissional, como nos mostra Silva (2011), seja no acompanhamento familiar do desempenho discente, como nos mostram Fevorini e Lomônaco (2009, p. 82):

\footnotetext{
1 Ver em http://agenciabrasil.ebc.com.br/educacao/noticia/2018-09/direito-pedagogia-e-administracao-sao-cursosmais-procurados acessado em 20/10/2018

2 Ver em http://www2.camara.leg.br/atividade-legislativa/estudos-e-notas-tecnicas/areas-daconle/tema11/expansao-da-educacao-superior-sob-os-planos-nacionais-da-educacao-expectativas-fatos-eperspectivas_aparecida-andres acesso em 20/10/2018
} 
A"chatice" das reuniões parece ser mais tolerada pelas mães do que pelos pais. Quando a entrevista foi com o casal, apenas um deles disse que vão juntos sempre; outros disseram que vão juntos quando podem, mas em geral a mãe costuma ir mais. Ainda houve umcasal em que a marido nunca vai. Talvez por aspectos afetivos e psicológicos e/ou culturais e sociais, o cuidado com a prole ainda parece ser mais uma tarefa feminina do que masculina.

Esses dados coletados na pesquisa, de 95\% de mulheres entre os ingressantes do curso, reforçam uma percepção histórica da educação enquanto área profissional feminina, como nos mostram diversos autores:

A profissão docente permitiu às mulheres o acesso a um dos espaços públicos anteriormente frequentado pelos homens. No entanto, essa profissão vai ser representada como similar ao trabalho no lar: o cuidar das crianças. Essa concepção é utilizada para naturalizar/reforçar o magistério, especialmente das séries iniciais, como uma profissão feminina. (SILVA, 2011, p. 34)

A associação entre educação e gênero feminino parece estar marcada por um aspecto ideológico, na perspectiva marxista ${ }^{3}$, de ilusão acerca da realidade, que aliena as mulheres em relação a seus direitos sociais e a elas confere uma associação a um aspecto de docilidade e submissão. Nesse sentido, Louro (1997, p.88) fala sobre a associação entre educação e feminilidade: "elas organizam e ocupam o espaço, elas são as professoras; a atividade escolar é marcada pelo cuidado, pela vigilância e pela educação, tarefas tradicionalmente femininas" (LOURO, 1997, p. 88). A relação entre docência e feminilidade é, portanto, fruto de uma construção histórica que estereotipa e estigmatiza os dois conceitos.

No que se refere a faixa etária dos discentes pesquisados, 70\% possuem entre 17 e 25 anos de idade, outros 15\% tem entre 26 e 40 anos e 7\% acima de 41 anos. 8\% dos respondentes não revelaram a idade. No que diz respeito à etnia, o questionário seguiu os termos definidos pelo Instituto Brasileiro de Geografia e Estatística (IBGE) ao listar as opções e encontrou as seguintes respostas: 34\% brancos, 26\% pretos, $34 \%$ pardos, $1 \%$ indígena e $2 \%$ amarelos. Importante ressaltar que, no quesito etnia, o pesquisador não fez nenhum juízo de valor no fornecimento das opções ou na validação das respostas, ficando registrado a autodeclaração de cada respondente. Percebe-se que, em relação ao Censo do IBGE de 2010, as respostas coletadas na pesquisa apresentam um equilíbrio no que se refere a brancos $(47,7 \%)$ e pardos $(43,1 \%)$, no entanto, uma relativa diferença em relação aos que se declararam pretos $(7,6 \%)$, visto que a representatividade de pretos no curso de pedagogia pesquisado é quase bem superior aos que se declaram pretos no Censo de 2010. 88\% dos entrevistados declararam ser oriundo de escola pública e $12 \%$ de escola privada. No que diz respeito ao nível de escolaridade dos pais, dividiu-se da seguinte forma: com relação ao pai, $6 \%$ analfabeto, 36\% fundamental incompleto, $13 \%$ fundamental completo, $8 \%$ médio incompleto, $24 \%$ médio completo, $3 \%$ superior incompleto e $6 \%$ superior completo. Com relação à mãe, obtivemos os seguintes dados: $4 \%$ analfabeta, $27 \%$ fundamental incompleto, $10 \%$ fundamental completo, $10 \%$ médio incompleto, $31 \%$ médio completo, $5 \%$ superior incompleto, $5 \%$ superior completo, $6 \%$ com Pós-Graduação e 2\% com Mestrado. Percebem-se dois fatores: maior escolaridade das mães em relação aos pais e baixo acesso dos pais ao Ensino Superior, fazendo assim com que grande parte desses graduandos em Pedagogia, ainda sem completar o curso, já superem o nível de escolaridade dos pais.

Com relação ao estado civil, $72 \%$ são solteiros, $21 \%$ casados, $3 \%$ divorciados e $1 \%$ viúvo. Dentre a população casada, o nível de escolaridade do cônjuge se desenhou da seguinte forma: 13\% fundamental incompleto, $22 \%$ fundamental completo, 9\% médio incompleto, $48 \%$ médio completo, 13\% superior incompleto e $9 \%$ superior completo.

Percebe-se, aqui, uma escolaridade maior do cônjuge em relação aos pais, no entanto, permanece baixo o índice de pessoas do núcleo familiar dos estudantes que completaram o curso superior.

Dentre os alunos pesquisados, 78\% declararam cursar Pedagogia com algum tipo de bolsa ou desconto. 5 alunos responderam estar na segunda graduação, especificando Gestão de Recursos Humanos, Logística e Licenciatura em Biologia como sendo a primeira graduação.

Temos, portanto, no universo pesquisado, uma predominância de jovens, oriundos de escola pública, com seu acesso e permanência no Ensino Superior condicionado a bolsas e condições econômicas peculiares,

\footnotetext{
${ }^{3}$ Em Marx (2007), o conceito de ideologia passa pelas relações dos homens com as classes sociais e suas relações de poder, associando as representações acerca da realidade aos seus posicionamentos de classe e, consequentemente, a relações sociais de fragmentação e dominação
} 
com relativo índice de pardos e negros, que, ao ingressar na universidade, já superam o nível de escolaridade dos pais. Esses dados apontam que o curso de Pedagogia atende uma classe humilde no quesito econômico, o que, no sistema capitalista, tem efeito direto no acesso a bens culturais.

Bourdieu remete ao conceito de capital para explicitar essa questão. De acordo com Bonnewitz, um dos interpretes da teoria Bourdieu, o capital:

Se acumula por meio de operações de investimento, transmite-se pela herança, permite extrair lucros segundo a oportunidade que o seu detentor tiver de operar as aplicações mais rentáveis. Estas características fazem dele um conceito heurístico se, como faz Bourdieu, seu uso não é limitado apenas à área econômica. (BONNEWITZ, 2003, p. 53)

São quatro os tipos de capital: Social: (se refere às relações sociais de um indivíduo ou grupo), Simbólico (se refere ao reconhecimento por partes de outros membros da sociedade), Cultural (se refere à intelectualidade nas suas diferentes formas) e Econômico (se refere aos fatores de produção e aos bens econômicos).

Em Bourdieu, a diferenciação se dá entre os agentes sociais, a quantidade de capital social que os mesmos possuem e de acordo com a estrutura desse capital. Em sua obra La Distincion (1979) esse autor explicita uma relação entre classes sociais e tendências culturais, questões de gosto. São características relacionais, que existem em relação a outros grupos. 0 responsável por essa diferenciação é o poder simbólico, já que este é reconhecido e aceito sem ser levado em conta como autoritário pelos que exercem e pelos que estão sujeitos a ele. Os que estão sujeitos ao poder simbólico tendem a reproduzir as maneiras da classe que ocupa o topo da hierarquia, seja quais forem essas maneiras (trajes, costumes, trejeitos).

Bourdieu (2002) critica a escola por ser elitista, desigual, reprodutora da cultura de uma determinada classe social, que recebe essa cultura através da transmissão doméstica do capital cultural, por isso são chamados pelo autor francês de herdeiros. Os alunos que não pertencem a essa classe, ao ingressar no sistema educacional, precisam, além de aprender os conteúdos, decifrar esse código cultural que abrange aspectos sociais, corporais e comportamentais. A escola, portanto, sob esse prisma, não é uma instituição plural, democrática e emancipatória, mas sim elitista e desigual, uma vez que transforma em dons e méritos pedagógicos as diferenças sociais entre os alunos. 0 público pesquisado, oriundo de camadas populares, filhos de famílias com baixa escolaridade e vindo da escola pública, por origem social enfrentou todas as imposições desse código cultural para permanecer na e concluir a Educação Básica e para ter acesso ao Ensino Superior. Não são, portanto, o público que Bourdieu classifica como herdeiros, em uma referência à transmissão doméstica do capital cultural que é consagrado na instituição escolar.

Quando questionados sobre o que motivou a escolha por Pedagogia, 66\% declararam "vocação para a docência", $17 \%$ mencionaram o leque de empregabilidade que o diploma de Pedagogia oferta, $7 \%$ relataram ter sido uma exigência do trabalho que já exercem (provavelmente a docência), $4 \%$ optaram por Pedagogia por não terem conseguido ingressar no curso que realmente desejavam e $1 \%$ apontaram o preço da mensalidade como fator de escolha. $7 \%$ dos respondentes assinalaram "outros", listando os seguintes motivos: 1 declarou não saber o motivo da escolha, 2 citaram o desejo de se especializar na área de atuação do atual trabalho, 1 explicou ter ingressado por receber bolsa integral e os demais não explicitaram a razão da escolha. Somando os que apontaram empregabilidade, exigência de trabalho, acessibilidade financeira, impossibilidade de cursar a graduação desejada e preço de mensalidade, temos $29 \%$ dos entrevistados, parcela relevante que reforça a discussão supracitada sobre o curso de Pedagogia ser alvo de uma classe trabalhadora, que não faz parte dos herdeiros do capital cultural tido como convencional nas instituições educacionais.

0 grande índice de respondentes que mencionaram a questão da vocação (66\%) nos leva ao questionamento deste conceito e nos remete a Weber, que argumenta que a vocação envolve paixão, mas também uma rigorosa especialização na ciência em questão, no caso da pesquisa, a educação:

a prática científica como vocação está condicionada, em primeiro lugar, pelo seguinte: a ciência entrou num estádio de especialização, antes desconhecido, e esta situação irá persistir para sempre . Não é só no plano externo, não, mas também internamente que as coisas se apresentam assim: o indivíduo pode adquirir a consciência segura de realizar algo de efectivamente perfeito no campo científico só no caso da mais rigorosa especialização. Todos os trabalhos que se estendem a outras áreas vizinhas, como os que ocasionalmente fazemos, como os que os sociólogos repetidamente devem fazer, estão onerados com a 
consciência resignada de que, quando muito, se facultam ao especialista questões úteis que ele, do ponto de vista da sua especialidade, não imaginaria com facilidade; que o seu trabalho deve necessariamente permanecer incompleto. Só graças a uma especialização rigorosa pode o trabalhador científico ter este sentimento pleno, que decerto só acontece uma vez e nunca mais se repete na vida: realizei, aqui, algo que irá durar. Hoje, um feito realmente definitivo e importante é sempre obra de especialistas. Quem, pois, não possuir a capacidade de, por assim dizer, pôr uns antolhos e de conceber que o destino da sua alma depende de ele comprovar justamente esta conjectura nesta passagem deste manuscrito, ficará sempre longe da ciência. Jamais conseguirá clarificar em si o que se poderia chamar de "vivência" da ciência. Sem esta estranha embriaguez, ridícula para todos os que a contemplam de fora, sem esta paixão, sem este sentimento de que "tiveram de passar milénios, antes de teres nascido, e outros milénios aguardaram em silêncio" - que confirmasses tal conjectura, não se tem vocação para a ciência; que faça outra coisa. Pois nada tem valor para o homem enquanto homem, se o não puder fazer com paixão. (WEBER, 1996, p. 61)

Interessante notar que $43 \%$ dos entrevistados afirmaram já atuar na educação. Desses, 26\% são professores, $17 \%$ mediadores, $51 \%$ auxiliares de creche e $8 \%$ assinalaram "outros", não especificando. Com relação ao tempo de atuação profissional na educação, 79\% assinalaram de 0 a 3 anos, $6 \%$ de 4 a 6 anos, 6\% de 7 a 10 anos e 4\% afirmaram atuar a mais de dez anos. Perguntados sobre as principais atividades que desenvolvem com alunos em sua rotina de trabalho, os respondentes afirmaram o seguinte: $40 \%$ mencionaram "exercícios, trabalhos lúdicos, musicalização e roda de histórias", 37\% afirmaram que "auxiliam o professor nas atividades com a turma", 16\% responderam "acompanhamento de alunos especiais" e 7\% responderam "outros", não especificando as ações. Ao relatar as principais atividades extraclasse, ou seja, sem alunos, 67\% responderam "pesquisas e confecções de atividades", 22\% responderam "construção de relatórios" e 11\% "preparação de diários". Interessante notar que, quando perguntados sobre a área de atuação desejada após a conclusão da graduação em Pedagogia, 48\% afirmaram o desejo de atuar na docência, 26\% relataram desejo de atuar na coordenação pedagógica e 9\% na gestão escolar. Foram mencionados também interesse em atuação na pedagogia hospitalar e na psicopedagogia (cerca de $8 \mathrm{em}$ pedagogia hospitalar e $10 \mathrm{em}$ psicopedagogia). Houve ainda 1 aluno inclinado para atuar na neuropsicopedagogia e 3 como orientadores educacionais. Esse montante totalizou $17 \%$ dos respondentes.

Os dados mostram que os alunos, recém ingressados no curso de Pedagogia, já possuem experiência profissional no campo educacional, o que garante uma faceta da especialização ressaltada por Weber, mas que, por outro lado, coloca na graduação em Pedagogia, a responsabilidade em formar esses educadores em seus aspectos teóricos e técnicos. As Diretrizes Curriculares Nacionais para o Curso de Pedagogia apontam as habilidades e competências a serem construídas nos egressos:

Para a formação do licenciado em Pedagogia é central: I - o conhecimento da escola como organização complexa que tem a função de promover a educação para e na cidadania; II - a pesquisa, a análise e a aplicação dos resultados de investigações de interesse da área educacional; III - a participação na gestão de processos educativos e na organização e funcionamento de sistemas e instituições de ensino. (BRASIL, 2006, art. 2)

O campo educacional possui seus embates em busca de posições de dominação e que esse campo sofre influência de outros campos - predominantemente o campo econômico e político - reforçando a ideia de que educação não é um processo neutro, mas sim demarcado por reprodução de valores de grupos dominantes, ao mesmo tempo em que se desenrolam batalhas ideológicas para que ocorra a mudança dos valores a serem reproduzidos. Essa tomada de consciência é fundamental para os educadores - entre eles os pedagogos - para que a reprodução, inerente ao processo educativo, ocorra de maneira crítica, consciente, em prol de valores que emancipem as pessoas que se encontram, na sociedade, em condição de submissão. A tomada de consciência supracitada depende, entre outros fatores, do domínio da teoria pedagógica que explicita e desvela as relações sociais e seus arranjos. Em suma, o pedagogo precisa dominar a teoria educacional para entender as relações sociais e - só então - modificá-las. Um conceito fundamental para exemplificar esse raciocínio é o conceito de didática.

Candau define a didática como técnica de dirigir e orientar a aprendizagem; "reflexão sistemática e busca de alternativas para os problemas da prática pedagógica" (1983, p. 12). Assim sendo, os profissionais da 
educação devem utilizar a didática não apenas como metodologia de ensino, mas como fundamento de reflexão e alternativas práticas aos problemas educacionais. Essa concepção reforça a indissociabilidade entre teoria e prática: as teorias nascem da realidade, de dilemas do real, e devem jogar luz sobre a realidade, buscando a solução de suas contradições. Teorias se desenvolvem em confronto com a prática. Relação dialógica e dialética onde uma transforma a outra. Para uma prática educativa que possibilite esse viés, é necessário o conhecimento da realidade e o domínio do arcabouço teórico. Ainda segundo Candau (ibidem), a didática possui três dimensões que devem ser incorporadas pelo pedagogo. São elas:

Dimensão Humana: diz respeito ao relacionamento interpessoal e seus derivados, como a afetividade, o respeito às diferentes bagagens culturais envolvidas no processo educativo e a noção de que qualquer relação professor-aluno é precedida por relação entre seres humanos, que trazem aos bancos escolares conhecimentos prévios que interferem diretamente não só no desempenho escolar, mas também em sua visão de mundo.

Dimensão Político-Social: diz respeito à percepção de que a educação não é neutra, mas um processo social, situado política, histórica e culturalmente através de leis, diretrizes e ideologias.

Dimensão Técnica: diz respeito ao domínio das etapas do processo educativo: Definição de objetivos, seleção de conteúdos, técnicas e recursos de ensino e avaliação, planejamento de curso e de aulas. É o aspecto Instrumental, Técnico, objetivo e racional, através do qual se organiza o processo ensino aprendizagem. Engloba o conhecimento das ferramentas e métodos educacionais e de quando, como e porque lançar mão de cada um deles. A educação é um processo global que para ser dominado precisa do entendimento das etapas, suas nuances e particularidades.

Cabe ressaltar ainda que essas três dimensões se caracterizam pela multidimensionalidade, ou seja, são indissociáveis uma vez que na realidade do processo educativo se articulam de maneira orgânica e dialógica. $\mathrm{O}$ aluno é um ser múltiplo, plural, que traz consigo aspectos sociais, psicológicos, políticos e pedagógicos. 0 mesmo ocorre com a instituição escolar. Então a prática pedagógica pressupõe a noção dessa mistura de dimensões.

A tendência critico-reprodutivista questiona uma visão simplista ingênua da escola, como uma instituição a parte da sociedade e por si só capaz de desfazer as contradições sociais. Ao denunciar essa escola, abrese a necessidade de uma escola que contemple a relação entre educação e transformação social, que é característica da pedagogia progressista. De acordo com Aranha, (1996, p. 211):

ao reconhecer que o homem está inserido em um contexto de relações sociais no qual a desigualdade é mantida, a tomada de consciência da opressão é importante justamente para orientar na direção de novas formas de ação pedagógica. Isso porque a escola se constitui como um elemento de continuidade, mas também de ruptura, na medida em que aí é possível problematizar a realidade e trabalhar as contradições sociais.

Essa pedagogia é caracterizada pela difusão de conteúdos originários de realidades sociais emergentes e seus saberes culturais, onde a figura autoritária do professor dá lugar a um protagonismo compartilhado com a ação discente, debruçados em postura dialógica sobre temas de caráter político que levem à reflexão crítica de problemas gerais, que possibilitem a consciência da realidade social para transformá-la.

Visa romper a dicotomia entre trabalho intelectual e manual, entre teoria e prática, que relega às classes trabalhadoras as posições de dominados nas relações sociais

O saber necessário, sobretudo para a classe trabalhadora, é o saber consistente e clareador a respeito do mundo físico e social. Para tanto, é importante que a educação dada ao povo não seja superficial e "aligeirada", mas que propicie a transmissão dos conteúdos necessários para atingir a consciência crítica a respeito das práticas sociais por meio das quais o mundo é construído. Nesse caso, todos teriam iguais oportunidades de acesso ao saber acumulado pela tradição. (ARANHA, 1996, p. 212)

Assim, o processo educativo deve ser ferramenta de mitigação das contradições sociais inerentes ao sistema capitalista. Ainda na ideia de que não há neutralidade no processo educativo, a educação pode ser instrumento de confirmação das desigualdades sociais ou ferramenta de emancipação social, como prega a pedagogia progressista.

A pedagogia progressista entende que o saber intelectual não deve ser abstrato, mas sim vinculado ao vivido. A formação para o trabalho não deve ser para formação de mão de obra, e sim para a compreensão 
discente do processo do fazer, utilizado nas técnicas atuais, dando ênfase ao conceito de Politecnia: Proposta que precisa necessariamente estar embasada em práticas pedagógicas concretas que rompam com a profissionalização estreita, por um lado, e com uma educação geral e propedêutica, livresca e descolada do mundo do trabalho, por outro. Nessa concepção pedagógica, a competência técnica deve ser aliada à consciência política, reiterando a construção do conceito de didática supracitada neste artigo. Sobre essa consciência política:

Nesse sentido, há uma relação visceral entre o processo educacional eo da sociedade. Existe uma pulsação no jogo entre as forças sociais e a educação. Isso ocorre de tal modo que, de um lado, a forma de organizar a educação reproduz integralmente a estruturação da sociedade: de outro lado, a atuação educacional pode ter efeitos desestruturadores, tornando-se fator de mudança social. Isso significa que o processo histórico depende também das ações dos sujeitos, sendo a educação uma mediação criadora e transformadora da História. (SEVERINO, 2001, p.72)

Para a mudança, é preciso partir da concepção de uma educação democrática, igualitária, que não apenas para receber uma educação enciclopédica e sem relação com o vivido, mas para reconstrução do saber e das relações sociais de forma dialética.

A qualidade dessa escola deverá ser medida não apenas pela quantidade de conteúdos transmitidos e assimilados, mas igualmente pela solidariedade de classe que tiver construído, pela possibilidade que todos os usuários da escola incluindo pais e comunidade - tiverem de utilizá-la como um espaço para a elaboração de sua cultura. Não devemos chamar o povo à escola para receber instruções, postulados, receitas, ameaças, repreensões e punições, mas para participar coletivamente da construção de um saber de pura experiência feito, que leve em conta as suas necessidades e o torne instrumento de luta (...) A escola deve ser também um centro irradiador da cultura popular, à disposição da comunidade, não para consumi-la, mas para recriá-la. (...) A escola como um espaço de ensino-aprendizagem será então um centro de debates de idéias, soluções, reflexões, aonde a organização popular vai sistematizando sua própria experiência. (FREIRE, 2001, p. 15-16)

Os participantes da pesquisa foram indagados sobre as principais características profissionais de um bom pedagogo. 31\% apontaram "dedicação e paciência", 18\% mencionaram o "amor pela profissão", 9\% apontaram "empatia. Senso crítico, ética, assiduidade na leitura, flexibilidade, ser facilitador da aprendizagem, didática e criatividade também foram apontados para esse perfil, totalizando $41 \%$ dos respondentes.

Foi possível perceber nas respostas critérios técnicos e de subjetividade humana. Sabemos que a afetividade é uma das ferramentas que podem ser utilizadas no fazer pedagógico. 0 amor pela profissão, aliado à especialização, complementa a noção Weberiana de vocação, não podendo cair no discurso ideológico-alienante que associa educação, docilidade e feminilidade, já mencionado neste artigo. Paulo Freire nos alerta para essa vigilância epistemológica:

Ensinar é profissão que envolve certa tarefa, certa militância, certa especificidade no seu cumprimento enquanto ser tia é viver uma relação de parentesco. Ser professora implica assumir uma profissão enquanto não se é tia por profissão. Se pode ser tio ou tia geograficamente ou afetivamente distante dos sobrinhos mas não se pode ser autenticamente professora, mesmo num trabalho a longa distância, "longe" dos alunos. (FREIRE, 1997, p.9)

Quando perguntados sobre a principal dificuldade enfrentada ao longo do curso, percebeu-se que alunos na faixa etária superior aos 30 anos, apontaram maiores dificuldades com o uso das tecnologias - aulas online e utilização do Sistema de Informações Acadêmicas (SIA) - e com o ritmo de estudos no Ensino Superior, mediante ao fato de estarem afastados a tempo das cadeiras estudantis; Imperícias com dicção (1), interação com os demais alunos (2), conciliar trabalho e estudo (7), distância entre casa e universidade (4), carga horária de aula (3), leitura (2) e preço do curso (4) também preencheram o quesito "maior dificuldade em relação ao curso". 


\section{CONSIDERAÇÕES FINAIS}

A pesquisa construiu o perfil dos ingressantes em Pedagogia na Universidade Estácio de Sá. 0 público pesquisado, em sua maioria é mulher, tem entre 17 e 25 anos, oriundas de Rede Pública de Educação Básica, filhas de pais e mães com baixo índice de escolaridade, em muitos casos não concluindo o Ensino Médio; solteiras, cursam o Ensino Superior com Bolsa ou algum outro tipo de financiamento, escolheram o curso por vocação à docência, porém tem como expectativas profissionais a atuação pedagógica em suas áreas diversas: coordenação, gestão, psicopedagogia, embora a própria docência seja mencionada de maneira considerável. Questões subjetivas como amor, dedicação e paciência lideram as percepções sobre o que é ser um bom pedagogo.

Os dados apontam que o curso de Pedagogia recebe alunos de classe popular, oriundos de famílias com pouco acesso à educação formal. Essa realidade aponta e reporta ao curso uma responsabilidade de transformação dessa clientela para a desafiadora tarefa da construção educacional de um país desigual:

O sistema capitalista, por sua natureza, é um sistema de contradições e desigualdades, fomentadas pelo incentivo à livre competição e acumulação de riqueza. No Brasil, essa desigualdade se faz presente nas relações sociais e nas condições estruturais de nossa sociedade. Dados ${ }^{4}$ apontam que pouco mais de $55 \%$ da riqueza brasileira está concentrada sob o poder de $10 \%$ da população, fazendo com que o Brasil ocupe a décima ${ }^{5}$ posição entre os países mais desiguais do mundo. A educação, tida por muitos como ferramenta de combate à desigualdade social, até então não mudou esse quadro em nosso país: dados ${ }^{6}$ da Avaliação Nacional de Alfabetização (ANA) de 2016 revelam que 54,73\% dos alunos com mais de 8 anos - que correspondem a $90 \%$ da população pesquisada - encontravam-se em condições insuficientes de leitura, a saber, no nível elementar. Em 2014, dois anos antes esse percentual era de 56,1\% Outros 45,2\% dos estudantes avaliados obtiveram níveis satisfatórios em leitura, com desempenho nos níveis 3 (adequado) e 4 (desejável). Em 2014, o índice encontrava-se em 43,8\%. A pesquisa da ANA aponta outro dado preocupante dentro do contexto capitalista:

Escolas de maior condição socioeconômica possuem o dobro de capacidade em alfabetizar alunos em relação às instituições de baixa condição socioeconômica. Esse quadro revela que a oferta de educação no Brasil, direito de todos segundo a Constituição Federal (BRASIL, 1988), possui um recorte de qualidade pautado em capital econômico. 0 público ingressante no curso de Pedagogia, embora possa não caracterizar os casos extremos de desigualdade brasileira, por sua origem social, conhece a ponta desse problema.

Darcy Ribeiro, ao falar sobre os dilemas do Brasil enquanto nação apontou a necessidade de um projeto político-social que priorize a classe popular brasileira:

O que faltou, sempre, foi espaço para movimentos sociais capazes de promover sua reversão. Faltou sempre, e falta ainda, clamorosamente, uma clara compreensão da história vivida, como necessária nas circunstâncias em que ocorreu, e um claro projeto alternativo de ordenação social, lucidamente formulado, que seja apoiado e adotado como seu pelas grandes maiorias. (RIBEIRO, 1995, p. 26)

Ao receber essa camada popular, o curso de Pedagogia está em foco: será capaz de transformar esses ingressantes em intelectuais orgânicos ${ }^{7}$ gramscinianos, capazes de propor mudanças sociais que contemplem a camada social de onde emergiram ou ofertará uma formação enciclopédica, reprodutora, de maneira alienada, que produza educadores que não questionam ou modificam o status quo, mantendo a educação enquanto uma profissão de docilidade, mais voltada para trabalhos manuais do que intelectuais, em oposição à integração de uma formação completa, que reúna ambos?

\footnotetext{
4 Ver em https://educacao.uol.com.br/colunas/priscila-cruz/2018/06/06/desigualdade-educacional-dar-mais-paraquem-tem-mais-desafios.htm acessado em 23/04/2019

5 Ver em http://www.br.undp.org/content/brazil/pt/home/presscenter/articles/2017/03/21/relat-rio-do-pnuddestaca-grupos-sociais-que-n-o-se-beneficiam-do-desenvolvimento-humano/ acessado em 23/04/2019

6 Ver em http://portal.mec.gov.br/ultimas-noticias/211-218175739/56321-mec-anuncia-politica-nacional-dealfabetizacao-para-reverter-estagnacao-na-aprendizagem

7 Ver em Cad. Cedes, Campinas, vol. 26, n. 70, p. 373-391, set./dez. 2006, disponível em http://www.scielo.br/pdf/\%0D/ccedes/v26n70/a06v2670.pdf
} 


\section{REFERÊNCIAS}

[1] Andres, Aparecida. Expansão da Educação Superior Sob os Planos Nacionais da Educação: Expectativas, Fatos e Perspectivas. Consultora Legislativa da Área XV Educação, Cultura e Desporto. Julho de 2017

[2] Aranha, Maria Lúcia de Arruda. Filosofia da educação. São Paulo, Moderna, 1996.

[3] Bonnewitz, Patrice. Primeiras lições sobre a sociologia de P. Bourdieu. Petrópolis; Vozes, 2003.

[4] Bourdieu, P.; Passeron, J.-C.Les héritiers.Lesétudiantsetlaculture. Paris: Ed. de Minuit, 1964.

[5] ___ As regras da arte: gênese e estrutura do campo literário. São Paulo: Cia das

[6] Letras, 1996.

[7] _ 0 capital social - notas provisórias. Em Nogueira, M. A. e Catani, A. (orgs.) Escritos de Educação. 4ª ed., Petrópolis, RJ: Vozes, 2002.

[8] Brasil. Resolução n.1, 15.5.2006. Diário Oficial da União, n.92, seção 1, p.11- 12, 16 maio 2006.

[9] Candau, Vera Maria (Org.). A didática em questão. 5 ed. Petrópolis: Vozes, 1983.

[10] Fevorini, L. B.; LOMÔNACO, J. F. B. O envolvimento da família na educação escolar dos filhos: um estudo exploratório com pais das camadas médias. Psicol. Educ., São Paulo, n. 28, p. 73-89, jun. 2009. Disponível em . Acesso em: 25 maios 2016.

[11] Freire, Paulo. A Educação na cidade. Prefácio de Moacir Gadotti e Carlos Alberto Torres;notas de Vicente Chel. 5 ed. São Paulo: Cortez, 2001.

[12] _ _ Professora sim, tia não: cartas a quem ousa ensinar. São Paulo: Olho d'água, 1997.

[13] Gandin, Danilo. A prática do planejamento participativo: na educação e em outras instituições, grupos e movimentos dos campos cultural, social, político, religioso e governamental. Petrópolis: Vozes, 1995.

[14] Louro, Guacira Lopes. Gênero, sexualidade e educação: uma perspectiva pósestruturalista. Petrópolis, RJ: Vozes. 1997.

[15] Marx, Karl; Engels, Friedrich. A ideologia alemã: crítica da mais recente filosofia alemã em seus representantes Feuerbach, B. Bauer e Stirner, e do socialismo alemão em seus diferentes profetas. São Paulo: Boitempo, 2007.

[16] Masetto, Marcos. Didática a aula como centro. Ed F.T.D. 1997, São Paulo. Quivy, R.; \& Campenhoudt, L. (2003). Manual de Investigação em Ciências Sociais (3ª ed.). Lisboa: Gradiva Ribeiro, Darcy - O povo brasileiro: a formação e o sentido do Brasil. São Paulo: Companhia das Letras, 1995.

[17] Silva, Kelly. Currículo, gênero e identidade na formação de professores/as. [Dissertação de Mestrado] UFJF, 2011.

[18] Weber, Max. A Política como Vocação. In: Weber, Max. Ciência e Política, Duas Vocações. São Paulo: Editora Cultrix, 1996. 


\section{Capítulo 3}

Saberes docentes na formação inicial do pedagogo: Um olhar sobre o PPP do Curso de Pedagogia da UFPI

\section{Poliana Alves dos Santos \\ Antônia Dalva França Carvalho}

Resumo: 0 presente artigo é uma pesquisa desenvolvida para o Trabalho de Conclusão de Curso (TCC) e tem como objetivo compreender que saberes docentes o projeto político-pedagógico (PPP) do curso de Pedagogia da Universidade Federal do Piauí (UFPI) preconiza para a formação inicial do pedagogo. Buscando também, refletir sobre como acontece esse processo de formação de saberes. Para tanto, analisamos o PPP do curso de Pedagogia da UFPI, desvelando sua racionalidade pedagógica, competências e saberes docentes. A pesquisa tem abordagem qualitativa e natureza descritiva, usamos como técnica de análise, a analise documental de Cellard (2014). Como fundamentação teórica para a pesquisa utilizamos os seguintes autores: Pimenta (2008), Gauthier (1998), Perrenoud (2000), Nóvoa (2002), Tardif (2008) entre outros autores. 0 PPP preconiza os demais saberes docentes para a formação do pedagogo, por meio da sua estruturação teórica e metodológica sistematizada para o sistema de formação dos discentes imersos no curso.

Palavras-chave: Formação inicial do pedagogo, Saberes docentes, Projeto políticopedagógico. 


\section{INTRODUÇÃO}

Nos últimos 20 anos expandiram os estudos sobre as tipologias e sistematização dos saberes dos professores. A intencionalidade de pesquisas nessa área surge da preocupação de proporcionar, por meio da pesquisa, reforço para a formação de professores, compartilhando da ideia que a sistematização do conhecimento contribui na instrução na prática de formação dos professores.

Com a compreensão de que o ensino é uma atividade realizada pelo professor que se apoia a um conjunto de conhecimentos, atribuiu um novo significado sobre a formação de professores, constituindo-se por um processo formativo que é incorporado por um sólido repertório de conhecimentos.

De acordo com Tardif $(2008$, p. 36) "O saber docente é definido como um saber plural, oriundos da formação profissional e de saberes disciplinares, curriculares e experienciais". Dessa forma o saber do professor para a sua formação e desenvolvimento da sua prática educativa em sala de aula, é incorporado por um conjunto de saberes articulados entre si, que faz parte também de um processo proveniente de uma formação, e não algo inato.

Posto que é na formação inicial de professores que os futuros profissionais da educação têm os primeiros aportes teóricos, metodológicos e práticos. Pautado nessas ideias, a pesquisa propõe compreender quais os saberes docentes a formação inicial de Licenciatura em Pedagogia da UFPI preconiza para a formação do pedagogo?

Com base no Projeto Político-pedagógico - PPP do curso de Pedagogia da Universidade Federal do Piauí (UFPI, 2009, p. 14) o Curso conta com um projeto político pedagógico voltado para a formação de um "[...]profissional empenhado na transformação da realidade educacional; capaz de realizar a práxis profissional e social". Isto é, as disciplinas inseridas no currículo do curso são direcionadas para o desenvolvimento da teoria e da prática docente e os saberes que precisam ser incorporados pelos discentes, para empenho do ser e fazer profissional.

Dessa forma elencamos como objetivo geral, compreender que saberes docentes o PPP do curso de Pedagogia da Universidade Federal do Piauí preconiza para a formação inicial do pedagogo. E para alcançar esse objetivo, elencamos como objetivos específicos, descrever que saberes docentes o Projeto Político-pedagógico do curso de Pedagogia da UFPI preconiza para a formação do Pedagogo; destacar a relevância do PPP da formação inicial de Pedagogia da UFPI para a formação do Pedagogo; descrever as competências e as habilidades do perfil do aluno egresso da UFPI.

Essa pesquisa possui papel relevante para a área da educação no âmbito da formação inicial de professores pois trará reflexões sobre os saberes que são constituídos na formação de professores, as implicações desses saberes na prática, como são constituídos e a importância para a formação inicial do Pedagogo. o interesse em desenvolver essa pesquisa partiu de pesquisas e estudos sobre a temática dos saberes docentes realizadas no Núcleo Interdisciplinar de Pesquisa em Educação e Epistemologia da Prática Profissional (NIPEEPP), entre os anos de 2018 e 2019.

Foi utilizado para o desenvolvimento da pesquisa a abordagem qualitativa, com viés descritivo e como técnica de análise, a análise documental. No decorrer da pesquisa pode-se notar que a estruturação do PPP do Curso de pedagogia da UFPI, oferece suportes teóricos e metodológicos na formação inicial do pedagogo, no que influencia diretamente no processo formativo dos saberes docentes na fase inicial da graduação.

\section{METODOLOGIA}

A pesquisa surge de uma dúvida, de inquietações diante de um fato, que busca procurar respostas para os questionamentos, e para que se tenha veracidade na pesquisa, é preciso seguir métodos e técnicas, que serviram como base, para nortear a pesquisa, porém, o pesquisador pode usar da criatividade seguindo os métodos adequados que caracterizam uma pesquisa científica.

O estudo proposto é uma pesquisa com abordagem qualitativa e natureza descritiva. A pesquisa é qualitativa, pois de acordo com Groulx (NASSER, 2014, p 96) "[...] a pesquisa qualitativa pretende mudar tanto a prática, quanto seus modos de gestão. 
Ela se esforça por conferir novas funções à pesquisa social [...]". A pesquisa qualitativa é vista de modo amplo, sendo utilizada de forma que se possa alcançar os objetivos, não importando o instrumento, busca dar condições para se mover a investigação.

É uma pesquisa de natureza descritiva pois colabora para melhor compreendermos o objeto da pesquisa, tendo em vista que a pesquisa descritiva possibilita segundo(CERVO, BERVIAN e DA SILVA, 2007, p. 32) "[...]a descrição deve ser suficientemente precisa para que o interlocutor ou o leitor seja capaz de viabilizar exatamente aquilo que o pesquisador observou". Desse modo, é importante fazer a descrição do objeto de estudo tanto para que o leitor compreenda a pesquisa bem como para que o pesquisador execute a pesquisa seguindo todos os critérios da rigidez científica.

A pesquisa teve como lócus de investigação a Universidade Federal do Piauí, e objeto de estudo o Projeto Político Pedagógico 2009 do Curso de Pedagogia da UFPI, pois o mesmo encontra-se em processo de reformulação.

Segundo Nasser (2014) a análise documental se constitui como um método bastante diferente de coleta de dados, em relação aos demais métodos também qualitativos. 0 autor destaca que "[...] coleta a analise das informações a partir de documentos também pressupõem a execução de alguns procedimentos, um tratamento das informações e objetividade por parte do pesquisador" (NASSER, 2014, p. 36). Ou seja, posto que, o objeto de pesquisa não permite ser analisado de outra forma a não ser utilizando a interpretação do conteúdo em que ele é constituído.

A análise dos dados é uma das principais partes do desenvolvimento de uma pesquisa, é também a parte mais complexa do todo da pesquisa. Assim utilizamos a análise documental como técnica de análise, respeitando a natureza, a abordagem e o método de coleta de dados. De acordo Cellard (2014) a análise documental consiste em um processo de análise preliminar devidamente completado, no qual este é o momento voltado para reunir todas as partes, sendo estas partes "[...] Os elementos da problemática ou do quadro teórico, contexto, autores, interesses, confiabilidade, natureza do texto e conceitos-chaves" (CELLARD, 2014, p. 303). Ou seja, tomando todas as partes será possível obter uma análise dos dados de forma satisfatória de acordo com os possíveis achados, tratamento, interpretação e diálogo dos dados com outras fontes teóricas.

\section{SABERES DA FORMAÇÃO INICIAL DE PROFESSORES: TIPOLOGIAS}

A formação inicial de professores é imprescindível, pois é dela que se provém os instrumentos primordiais para sua atuação no exercício das atividades em sala de aula. É nessa primeira parte da formação de professores que também se desconstroem ideários que giram entorno do que é ser professor. 0 velho paradigma bem antigo de que exercer a profissão docente é fácil, pois é só copiar o assunto no quadro, explicar o conteúdo e passar uma atividade. Tem-se a ideia de que o professor estuda pouco em sua formação e que se trata de uma graduação fácil, que não exige muito para que se forme nessa profissão.

Para Pimenta (2008, p. 20) no livro, Saberes pedagógicos e atividade docente, "o desafio, posto aos cursos de formação inicial é o de colaborar no processo de passagem dos alunos de seu ver o professor como aluno ao seu ver-se como professor". Transcreve claramente o real conceito atribuído ao ser professor no olhar do aluno, definição adquirida pela experiência do estudante, nos espaços escolares, e também atribuído socialmente. Esse fato é descrito por Tardif (2008, p. 38) como "saber proveniente da experiência, os saberes experienciais".

O processo de formação do professor é um mecanismo complexo, que exige dele compreensão do próprio processo do qual irá participar, entender o funcionamento do ensinar e o aprender. Os cursos de graduação de licenciaturas, principalmente os cursos de Pedagogia em suas raízes curriculares disponibiliza para essa formação disciplinas para a constituição desse profissional.

É também na formação inicial que se constroem os saberes práticos que fundamenta em um saber fazer, porém não se pode ir à prática sem ir antes ao que diz a teoria. Sabemos também que toda profissão para ser exercida precisa-se antes da "formalização dos saberes necessários para a execução das tarefas que lhes são alheias” (GAUTHIER, 1998, p. 20). Ou seja, um só saber não constitui uma formalização, visto que toda atividade, mobiliza mais de um saber. 
Tardif (2008, p. 60) "[...]atribui A noção de "saber" um sentido amplo, que engloba, os conhecimentos, competências, habilidades (ou aptidões) e as atitudes dos docentes". Assim também conforme Tardif (2008, p. 21) "o saber dos professores não provém de uma única fonte, mas decorre de várias fontes, inclusive de momentos da história de vida e da carreira profissional". Ou seja, o saber também é algo historicamente construído. Assim o autor destaca a pluralidade de saberes que caracteriza de como um amálgama de saberes oriundos da formação profissional e de saberes disciplinares, curriculares e saberes experienciais.

Tardif (2008, p. 36) específica que "[...]os saberes da formação profissional, são o conjunto de saberes transmitidos pelas instituições de formação professores". no qual não se finda em só produzir conhecimentos, mas se preocupa em englobá-los a prática do professor. Esse saber também está pautado na articulação entre ciência teórica e a ciência prática do professor, posto que a formação profissional dáse da junção das duas ciências. Como os saberes da formação profissional se aplica da mobilização dos saberes teóricos e práticos e utiliza da prática para formar novos saberes por meio da reflexão-açãoreflexão.

Tardif (2008, p. 38) se refere aos saberes disciplinares "como saberes sociais, que são disponibilizados na formação inicial ou continuada pelas instituições formadoras", especificando esse saber como saberes provenientes de várias áreas do conhecimento, no qual a universidade disponibiliza pelas disciplinas dos cursos de graduação, Tardif (2008).

Os saberes curriculares descrito por Tardif $(2008$, p. 38) são os saberes que "referem-se aos discursos, objetivos, conteúdos e métodos seguidos por uma instituição, pelo qual expressa os saberes sociais que são seguidos por ela e definidos como modelos da cultura erudita a ser espelhado, principalmente na formação".

Referente aos saberes experienciais Tardif (2008, p. 39) contempla que são "saberes específicos que o próprio professor desenvolve na prática de sua profissão, constituídos mediante as suas vivências no ambiente de trabalho e na compreensão de seu meio". Nesse ponto a construção desses saberes acontece de modo individual, quanto coletivo, que agregam ao professor hábitos e habilidades do saber-fazer e saber-ser. Os saberes da experiência segundo Tardif (2008) trata-se de uma prática erudita, na medida que se articula com diferentes saberes, por exemplo, os saberes sociais, quando transformados em saberes escolares, por meio dos saberes disciplinares e curriculares.

Ou seja, desse modo, caracteriza-se que o professor para desenvolver condições para sua prática precisa mobilizar os saberes ditos "socialmente eruditos", que corresponde a dinâmica: saberes sociais modificados pelos sabres curriculares e disciplinares que espera-se que o professor seja capaz de dominar, integrar e mobilizar os demais saberes a favor de sua prática.

\subsection{IMPLICAÇÕES DOS SABERES PARA A FORMAÇÃO DOCENTE: RETROSPECTIVA DOS MODELOS DA FORMAÇÃO DE PROFESSORES}

Para iniciar a discussão deste tópico, faremos uma retrospectiva em relação as reformas ocorridas nos cursos de formação docente, no qual apresentam seguimento norteado por algum modelo de racionalidade. De acordo com Carvalho (2007, p. 36) racionalidade pedagógica Trata-se de "um conjunto de valores preferenciais[...]", assim esse conceito adequa-se pois a racionalidade pedagógica práticareflexiva norteia todo o curso, suas ideia, pressuposto, assim como está presente no processo de ensino e aprendizagem.

A racionalidade técnica conhecida também como pedagogia científica e epistemologia da racionalidade técnica, prioriza a razão instrumental, o entendimento sobre o trabalho de ensino não se relaciona a valorização dos saberes, aos quais os professores portam, mas sim, se opõem à esses saberes, valorizando os saberes com viés científicos e técnicos. Dessa forma, rejeita-se o desenvolvimento de uma prática reflexiva crítica.

A racionalidade prática, compartilha de suportes teóricos, porém nessa racionalidade reina a prática, que valoriza a experiência para adquirir os conhecimentos da profissão docente, no qual espera-se que o professor defina e avalie os processos educativos que funcionam na ação e os que menos deram certos. 
Chegamos agora na racionalidade crítica de formação de professores. 0 saber na racionalidade crítica não é fragmentado, como as duas outras. A visão desse modelo é de transformação social pela construção de conhecimentos, a partir da reflexão. 0 pressuposto da racionalidade crítica busca sempre a reformulação e interpretação profunda das coisas dos fatos, das ações e dos conceitos construídos, levando a refutar sobre o que está estabelecido dando um novo significado. A saber Menezes e Lima (2016, p. 52) refletem sobre o trabalho hermenêutico no contexto social do mundo da vida, que ensina "[...]a reaprender a ver, e a reaprender a perceber as coisas".

No modelo sócio-crítico, o educador é alguém que problematiza, que levanta problemas e media diálogos críticos em sua sala de aula. Refletir sobre sua prática vai muito mais além de um aspecto técnico, mas é adquirir profundidade reflexiva, no qual própria realidade escolar exige. Um professor/pedagogo reflexivo faz uso dos saberes dos quais é portador.

De acordo com Habermas (1987 a) apud Mion (2002, p. 211) "precisamos igualmente do conhecimento técnico e do conhecimento prático interpretativo, para obtermos um conhecimento reflexivo". Ou seja, na visão de Habermas, é da mobilização da racionalidade técnica e da racionalidade prática que pode-se chegar ao pensamento crítico.

\subsection{CENÁRIO DA FORMAÇÃO INICIAL DO PEDAGOGO: DESCRIÇÃO DO PPP DO CURSO DE PEDAGOGIA DA UFPI}

Os discursos escrito e sistemático do PPP do Curso de Pedagogia da UFPI, entendemos como um conjunto de ideias geradas por um grupo de interlocutores sociais, com saberes e competências, no qual, os habilita para tal atividade, de elaborar o presente documento que norteia o curso de Pedagogia, na construção dos saberes dos sujeitos que vivenciam, a demais formação.

As ideias descritas acima, trata-se da organização do PPP. De acordo com Therrien e Pinho (2011, p. 91) "o projeto político-pedagógico traduz a visão macro do que a instituição pretende ou idealiza fazer, seus objetivos, metas e estratégias[...]". Ou seja, todas as ações contidas nesse documento trás descrito os objetivos, que é o que se espera promover no curso; as competências a serem desenvolvidas na formação do pedagogo, bem como a matriz curricular e as ideias que norteiam todo o projeto, que move as ações do curso.

De acordo com o que está detalhado no PPP do curso de Pedagogia da UFPI (2009, p. 18) o objetivo geral, é favorecer "a formação docente do pedagogo para atuar na Educação infantil, nos anos iniciais do Ensino Fundamental, na formação pedagógica do profissional docente e na Gestão Educacional, de forma a atuar na realidade social de modo crítico e transformador". Tendo em vista, formar o pedagogo capaz de resolver, com competência, problemas que eventualmente será encontrado na realidade do seu trabalho, sempre levando em consideração e respeito as dimensões humanas, éticas, políticas, técnicas e sociais que circundam a profissão docente.

As competências e habilidades que se pretende que o aluno do Curso de Pedagogia da UFPI desenvolva descrito no PPP (2009) projeta em seu futuro pedagogo um sujeito capaz de mobilizar os saberes adquiridos durante toda a formação a favor da educação, por meio desses conhecimentos refletir sobre o contexto da realidade a qual estará inserido, transformando sua práxis educativa de acordo com os saberes históricos, sociais, políticos, econômicos e psicológicos que fundamentaram essa formação. Perrenoud (2000) citado por Parente (2011, p. 350) "competência é a faculdade de mobilizar um conjunto de recursos cognitivos (saberes, capacidades, informações etc.)". Desse modo evidenciamos a importância dos suportes teóricos e metodológicos para a formação de competências e habilidades no discente. De acordo com PPP do Curso de Pedagogia da UFPI (2009, p. 26):

Isso significa que o currículo deste curso é orientado pela racionalidade pedagógica prático-reflexiva na perspectiva crítica, que deverá tomar a reflexão-ação como elemento norteador da construção de competências profissionais do pedagogo, através da constituição de saberes específicos do trabalho docente. (PPP, 2009, p. 26).

De acordo com a opinião de Tardif (2008, p. 203) a respeito da racionalidade dos saberes dos professores, "[...] esse conceito de racionalidade não é somente uma construção teórica. Ele se refere também a uma "capacidade" essencial de elaborar razões, de dar motivos para justificar e orientar suas ações." 
Toma como fundamento básico, um currículo pautado no pressuposto crítico-reflexivo, que visa fazer com que se desenvolva um pensamento crítico levando o educando a percepção dos aspectos sociais, econômicos e culturais contraditórios, favorecendo desse modo a difusão do saber e o desenvolvimento da produção de conhecimento. Desse modo busca um princípio fundamentado em uma "relação orgânica entre teoria e prática, no qual todo conteúdo curricular do curso deve fundamentar-se na articulação teórico-prática, que representa a etapa essencial do processo ensino-aprendizagem", PPP (UFPI, 2009, p.25).

\section{RESULTADOS E DISCUSSÃO}

Buscando atingir os objetivos da presente pesquisa, foram selecionadas as demais categorias:

Tabela 1: Categorias de análises de dados

\begin{tabular}{|l|l|}
\hline $1^{\text {a }}$ categoria & Saberes docentes da formação inicial do pedagogo da UFPI \\
\hline $2^{\text {a }}$ categoria & Competências do perfil do egresso da UFPI \\
\hline $3^{\text {a }}$ categoria & Racionalidade pedagógica do PPP \\
\hline
\end{tabular}

Fonte: Dados da pesquisa, 2009.

\section{5. $1^{\circ}$ CATEGORIA: SABERES DOCENTES DA FORMAÇÃO INICIAL DO PEDAGOGO DA UFPI}

Notificou-se que o curso preconiza os saberes necessários para a formação inicial do pedagogo, assim como Gauthier (1998) nos afirma que para qualquer profissão para ser exercida necessita da formalização dos saberes necessários para a execução das tarefas que lhes são atribuídas. desse modo evidenciou-se no PPP, os demais saberes descritos por Tardif (2008), saberes curriculares, saberes disciplinares, saberes experienciais e os saberes profissionais. No qual podemos notar no trecho do PPP (UFPI, 2009, p. 12):

Nesta ótica, a interdisciplinaridade no currículo de Pedagogia tem a finalidade de integrar e, ao mesmo tempo, gerar um conhecimento próprio à luz da interpenetração dos conteúdos e dos métodos das ciências auxiliares envolvidas no estudo da prática educativa. (2009, p. 12).

Podemos aferir que o PPP do Curso de Pedagogia da UFPI contemplam os saberes da formação profissional, saberes que nascem na formação inicial no âmbito das instituições e se concretizam na prática, que no qual se constituem dos demais saberes docentes, os saberes disciplinares, que estão presentes nas disciplinas do Curso de Pedagogia da UFPI; os saberes curriculares, no qual são os saberes que norteiam um currículo e os saberes experienciais, que são os saberes provenientes da experiência.

\section{1. ${ }^{\text {a }}$ CATEGORIA: COMPETÊNCIAS DO PERFIL DO EGRESSO DA UFPI}

Através do princípio “Concentração das matérias curriculares em conteúdos da Pedagogia”, o PPP (2009, p. 14) quer favorecer uma formação sólida em conhecimentos e saberes educacionais e a partir deles explicar a organização social do modelo educacional, direcionados pelos aspetos teóricos e metodológicos, para o desenvolvimento das competências profissionais docentes. A noção de competência tida pelo PPP (2009) está: “[...] vinculada a práxis educativa crítica e transformadora decorrente de um processo de formação que tanto tem a epistemologia da prática como princípio fundante, como requer a interdisciplinaridade" (PPP, 2009, p. 20).

De acordo com Perrenoud (2000), Parente (2011, p. 350) define competência como "a faculdade de mobilizar um conjunto de recursos cognitivos (saberes, capacidades, informações etc.)". Desse modo evidenciamos no PPP a relação dos aportes teóricos e metodológicos para a formação das competências. 


\section{2. $3^{\circ}$ CATEGORIA: RACIONALIDADE PEDAGÓGICA DO PPP}

Consideramos que o PPP apresenta a presença de três racionalidades, a racionalidade prática, técnica e a crítica, para a constituição da racionalidade que se encontra em seguimento pelo PPP, sendo esta a racionalidade crítica constituída por meio da relação entre a teoria e a prática, considerando a articulação das duas para desenvolver por meio destas a reflexão, a criticidade. Assim de acordo com Nóvoa (2002, p. 64) “[...] formação se constitui pela articulação da diversificação dos modelos [...]”.

De acordo com o PPP do Curso $(2009$, p. 26) “[...] o currículo deste curso é orientado pela racionalidade pedagógica prático-reflexiva na perspectiva crítica[...]". Desse modo buscamos comprovar essa racionalidade analisando o PPP do Curso de Pedagogia da UFPI.

Todos os indicadores "pressuposto, práxis, aprendizagem, prática educativa, avaliação, professor, aluno, competências, conhecimento, educação e planejamento" PPP (UFPI), p. 31) trabalham considerando o pressuposto da racionalidade pedagógica prática-reflexiva, desenvolvendo um trabalho teórico e metodológico direcionados principalmente pela visão reflexiva da prática, produção de conhecimento, aplicação na prática, reflexão das ações produzidas, transformação da prática em conhecimento científico, articulação dos saberes produzidos e adquiridos pelo ensino e aprendizagem guiado pela racionalidade pedagógica prática-reflexiva. E que todo o processo de ensino e aprendizagem está ancorado na racionalidade a que o PPP declara.

\section{CONSIDERAÇÕES FINAIS}

O presente estudo teve como objetivo compreender que saberes docentes o PPP do curso de Pedagogia da UFPI preconiza para a formação inicial do pedagogo. Para alcançá-lo, utilizamos a pesquisa qualitativa de natureza descritiva e como técnica de análise, a análise documental.

Os dados analisados mostraram que a formação inicial do pedagogo da UFPI, de acordo com as análises feitas do PPP do curso de Pedagogia, preconizam os saberes profissionais para a formação do pedagogo, sendo que os saberes profissionais se constitui por meio da articulação de outros saberes também preconizados pela formatação, no qual este conjunto de saberes mobilizados, formam o saber profissional.

Nessa perspectiva, notamos que os saberes da docência, são saberes para a prática docente, e no decorrer das análises percebemos, a forte ligação que norteia a formação inicial do pedagogo da UFPI, a ligação entre teoria e prática, que se encontra presente, nas disciplinas, contidas também nas propostas de programas de pesquisa, extensão e de iniciação à docência ou a pesquisa, nos estágios supervisionados, que é requisito importante na formação.

Considerando esses aspectos, a relação entre teoria e prática está também ligada a formação de competências e habilidades ao futuro pedagogo. Estando de acordo com os objetivos que é de formar o profissional para atuar na Educação Infantil e dos anos iniciais do Ensino Fundamental e a para atuar na gestão educacional ou onde houver possibilidade de realizar ações educativas.

Diante das análises, percebemos que o Curso tem o objetivo de formar um sujeito crítico-reflexivo, ético, pautados em valores democráticos. Para isso, sua matriz curricular agrega para a formação de saberes e competências a respeito da ética democrática, disciplinas das várias áreas do conhecimento. Interpretamos desse modo que o egresso do curso de Pedagogia da UFPI é um sujeito formado para ter uma visão do todo e refletir sobre as questões sociais.

Seguindo as análises, afirmamos a racionalidade que rege o PPP do curso de Pedagogia da UFPI, sendo está que se apresenta no PPP (2009) A racionalidade pedagógica prático-reflexiva. Comprovados tal racionalidade diante das análises, tanto dos saberes, como das competências aqui pesquisadas, do perfil do egresso sujeito crítico-reflexivo que a UFPI pretende formar. Formação que parte desta racionalidade.

Ressaltamos que o estudo realizado, servirá como fonte de pesquisa para outros trabalhos científicos, para aqueles que se pautam a pesquisar sobre os saberes docentes, competências e racionalidade pedagógica na formação inicial do pedagogo, visto que o trabalho apresenta vários olhares no âmbito dos saberes, e o processo da formação dos mesmos, tornando assim um trabalho rico em informações e inovador na articulação de suas ideias. 


\section{REFERÊNCIAS}

[1] Carvalho, Antônia Dalva França. A racionalidade pedagógica da ação dos formadores de professores: Um estudo sobre a epistemologia da prática docente nos cursos de licenciatura da Universidade Federal do Piauí. Tese de Doutorado. UFPI-CE, 2007.

[2] Cellard, André. A análise documental. Tradução, Nasser, Ana C. pesquisa qualitativa- Enfoques Epistemológicos e metodológicos. 4 ed. Petrópolis, Rj: Vozes, 2014.

[3] Cervo, A. L. Bervian, P. A. da Silva, R. Metodologia Científica. 6 ed. São Paulo: Pearson Prentice Hall, 2007.

[4] Gauthier, C. Por uma Teoria da pedagogia: pesquisa contemporânea sobre o saber docente. Trad. Pereira. F. Ed: UNIJUÍ, 1998.

[5] Groulx, Lionel-Henri. Contribuição da pesquisa qualitativa à pesquisa social. Tradução, Nasser, Ana C. pesquisa qualitativa- Enfoques Epistemológicos e metodológicos. 4 ed. Petrópolis, Rj: Vozes, 2014.

[6] Menezes, Anderson de Alencar. Lima, José Aparecido de Oliveira. A “Consciência" Hermenêutica em Habermas: Interfaces e Diálogos. Ágora Filosófica. Ano 16 n. 3 (especial), jul./dez. 2016.

[7] Mion, Rejane aurora. Investigação-ação e aformação de professores em física. Tese de Doutorado. UFSC Florianópolis, 2002.

[8] Nóvoa, A. Formação de professores e trabalho pedagógico. Lisboa: Educa 2002.

[9] Perrenoud, Philippe. Dez novas competências para ensinar. Porto Alegre: Artmed, 2000.

[10] Pimenta, Selma Garrido. (Org). Saberes pedagógicos e atividade docente. São Paulo: Cortez, 2008.

[11] Poupart, Jean. Deslauriers, Jean -Pierre. Groulx, L. Laperriére, A. Mayer, R. Pires, A. A pesquisa qualitativaEnfoques Epistemológicos e metodológicos. 4 ed. Tradução, Nasser, Ana C. Petrópolis, Rj: Vozes, 2014.

[12] Tardif, Maurice. Saberes docentes e formação profissional. 9 ed. Petrópolis, RJ: Vozes, 2008. 325p.

[13] Therrien, Jaques. Pinho, Ruth C. S. Caminhos de uma pesquisa colaborativa para análise de Projeto Político Pedagógico do curso de Pedagogia a partir do currículo é práticas docentes do curso de ciências contábeis da Universidade Federal do Ceará na perspectiva da teoria da ação comunicativa. Dias, Ana. M. I. Bittencourt. E. P. L. Santos, S. F. R. Fernandes, Z. B. (org). Docência universitária- saberes e práticas em construção. Pará, IBAMA, 2011, p. 90-99.

[14] UFPI, Projeto Político-Pedagógico do Curso de Pedagogia da UFPI. Teresina- PI: UFPI, 2009. 


\section{Capítulo 4}

\section{A atividade docente de professores estagiários: 0 que a autoconfrontação tem a revelar}

\section{Wescley Batista Lopes \\ Luciana Peixoto Bessa \\ Elisandra Maria Magalhães \\ Rozania Maria Alves de Moraes}

Resumo: Atualmente, a partir de uma perspectiva inter/transdisciplinar, os estudos desenvolvidos em Linguística Aplicada têm buscado dialogar com outras áreas do saber, como as Ciências do Trabalho e da Educação, no intuito de estudar a atividade professoral, a partir da análise das verbalizações dos docentes, de modo a contribuir com a formação inicial e/ou continuada desses profissionais. Diversas pesquisas realizadas no Brasil e no exterior, ancoradas nos aportes teóricos e metodológicos da Clínica da Atividade e na Ergonomia de tradição francófona, têm tomado a atividade de professores estagiários como objeto de estudo e lançado mão do quadro metodológico da autoconfrontação, o qual tem o aporte da teoria do desenvolvimento humano de Vigotski e da filosofia círculo-bakhtiniana da linguagem. Assim, recorrendo à Clínica da Atividade, à autoconfrontação, e apoiado na (co)análise da atividade de dois professores estagiários de Letras-Francês, participantes de uma pesquisa de mestrado, este estudo objetiva apresentar como o quadro teórico-metodológico da autoconfrontação pode contribuir para a formação inicial de professores, sobretudo por possibilitar que estagiários passem a ter uma postura crítico-reflexiva a respeito de sua atividade. Entendemos que a análise dos enunciados dos estagiários, emergentes das trocas verbais provenientes das interações (e coanálises) durante as fases da autoconfrontação, possibilitou-nos identificar e compreender os anseios, sobretudo a insegurança, inerente aos professores estagiários.

Palavras-chave: atividade docente, professor estagiário, clínica da atividade, autoconfrontação 


\section{INTRODUÇÃO}

Diferente de uma concepção em que a docência é considerada um dom, ideia presente no senso comum, para as Ciências do Trabalho, sobretudo a Ergonomia e a Clínica da Atividade, a atividade de professores é vista como um trabalho, com singularidades inerentes às atividades laborais, tais como lidar com coletivos $^{8}$ profissionais e com imprevistos, responder a (e ressignificar) prescrições (Bessa; Silva; Moraes, 2018), para citar alguns.

A partir de uma perspectiva inter/transdisciplinar, a Linguística Aplicada busca dialogar com demais áreas do saber, como as Ciências do Trabalho e a Educação, por exemplo, no intuito de estudar a atividade de professores, a partir da análise de suas verbalizações sobre a atividade docente, de modo a contribuir com a formação seja inicial e/ou continuada desses profissionais.

Diversas pesquisas realizadas no Brasil e no exterior, ancoradas principalmente nos aportes teóricos e metodológicos da Ergonomia de tradição francófona ${ }^{9}$ e na Clínica da Atividade, têm tomado o discurso de professores estagiários sobre a sua atividade como objeto de estudo, a partir de um quadro metodológico de análise de situações do trabalho, denominado autoconfrontação (Viera; Faïta, 2003). De natureza interventiva, esses estudos, em sua maioria, buscam na teoria sócio-histórico-cultural de Vigotski (2008) os caminhos para investigar o desenvolvimento desses profissionais e, com base em uma compreensão dialógica ou sociointeracionista da linguagem, ajudar a resolver ou a remediar conflitos que se produzem no contexto investigado.

De uma maneira geral, a autoconfrontação consiste no confronto do(s) profissional(is) com imagens selecionadas a partir da filmagem de si mesmo(s) (ou de seus pares) em atividade concreta. Dessa forma, estando no papel de protagonistas, é possibilitado a esses profissionais (co)analisarem sua atividade, tratando-se, portanto, de um "processo dialógico que permite ao profissional [...] a partir do filme da sua própria atividade, ressignificar, em um novo contexto, a experiência vivida” (Moraes; Magalhães, 2017, p. 109).

No que diz respeito ao início da carreira de professores, consoante Huberman (1992), os três primeiros anos da carreira docente são considerados como uma fase de entrada no métier (Clot, 2010) docente, momento marcado pela aquisição de competências e de conhecimentos provenientes da prática, além de ser, nas palavras de Lopes (2017), "um momento repleto de incertezas, inseguranças, medos e dúvidas sobre o próprio saber pedagógico e os outros saberes professorais que o profissional da educação deve desenvolver" (Lopes, 2017, p. 52).

Assim, recorremos à Clínica da Atividade, à Ergonomia de tradição francófona e à autoconfrontação para, a partir da coanálise da atividade de dois professores estagiários de Letras-Francês, buscar compreender um pouco da entrada destes no métier docente, junto com suas incertezas, partindo de uma análise translinguística (Bakhtin, 2011) das verbalizações desses professores em formação inicial.

Dessa forma, servindo-se da análise de excertos extraídos do corpus da pesquisa de Lopes (2017) ${ }^{10}$, este estudo objetiva apresentar como o quadro teórico-metodológico da autoconfrontação pode contribuir na formação inicial de professores, sobretudo por possibilitar que estagiários passem a ter uma postura crítico-reflexiva a respeito de sua atividade.

Entendemos que a análise dos enunciados (Bakhtin, 2011) dos estagiários, emergentes das trocas verbais provenientes das interações (e coanálises) durante as etapas da autoconfrontação conduzidas por Lopes (2017), possibilitou-nos identificar e compreender anseios, sobretudo a insegurança, comum aos professores estagiários.

\footnotetext{
${ }^{8}$ Segundo Caroly (2010), o coletivo é estabelecido quando vários trabalhadores contribuem para a realização de um trabalho comum, em conformidade com suas próprias regras de ação e com as regras do méter. Para a autora, "[...] 0 coletivo de trabalho constitui-se em e através desta atividade da produção das regras" (Caroly, 2010, p. 89). No original: "[...] Le collectif de travail se constitue dans et par cette activité de production de règles ».

9 Para uma discussão mais aprofundadas sobre a Ergonomia de tradição francófona ou Ergonomia da Atividade, consultar Wisner (1995) e Daniellou (1996).

10 Pesquisa apreciada e aprovada pelo Comitê de Ética da Universidade Estadual do Ceará, em 13/03/2017, conforme Certificado de Apresentação para Apreciação Ética (CAAE) no 63971617.2.0000.5534 e parecer no 1.962.271.
} 


\section{0 QUADRO METODOLÓGICO DA AUTOCONFRONTAÇÃO}

O quadro metodológico de análise de situações do trabalho - autoconfrontação - foi desenvolvido na França, na segunda metade dos anos 1980, pelo linguista e pesquisador Daniel Faïta. Trata-se de um método indireto de análise da atividade que busca "[...] compreender o processo de produção, reflexão e transformação da atividade" (Viera; Faïta, 2003, p. 27-28) a partir do discurso profissional, buscando, assim, os caminhos para ajudar a resolver e/ou a remediar conflitos que se produzem no ambiente de trabalho, além de ampliar e reestabelecer o poder de agir ${ }^{11}$ dos sujeitos envolvidos. De acordo com Araújo (2018, p. 304), “[...] trata-se de um quadro metodológico composto de processos dialógicos motivados pela visualização da atividade gravada em vídeo".

Em termos gerais, o processo da autoconfrontação pode ser desencadeado de duas maneiras: através de uma demanda proveniente de um local de trabalho ou através da inquietação de pesquisadores. $\mathrm{Na}$ França, podemos encontrar inúmeros exemplos de empresas que formulam solicitações para os ergonomistas na forma de demanda. No Brasil, diferente do contexto francês, a maioria das investigações/ intervenções são provenientes de inquietações de pesquisadores ligados aos programas de Pós-graduação, que buscam investigar contextos específicos. Podemos citar como exemplo a pesquisa de Lopes (2017), fonte do corpus que analisaremos a seguir. Todavia, em contexto nacional também podemos encontrar pesquisas/intervenções realizadas a partir de demandas provenientes do local investigado.

Segundo Vieira e Faïta (2003, p. 29), a filosofia círculo-bakhtiniana da linguagem oportunizou a tomada do "[...] enunciado concreto [do profissional] como a base material das análises de situações, de atos e pensamentos humanos, fornecendo às ciências humanas um novo objeto: as relações dialógicas, situadas na fronteira entre discurso e atividade". Assim, esse processo dialógico e reflexivo sobre a atividade pode ser dividido em algumas fases, a saber: a constituição do grupo de análise; a filmagem do profissional em atividade; a autoconfrontação simples (ACS); a autoconfrontação cruzada (ACC), e o retorno ao coletivo (RC) (Vieira; Faïta, 2003; Moraes; Magalhães, 2017).

A composição do grupo de análise - primeira fase do processo - compreende a seleção e a divisão dos sujeitos que participarão da pesquisa/ intervenção. Os sujeitos ligados ao estudo são divididos em dois pares: os protagonistas - pares de profissionais que serão filmados em seu contexto real de atividade e participarão de todas as fases do processo de investigação - e o coletivo de trabalho - sujeitos ligados à atividade e ao contexto de trabalho dos protagonistas e que participação da última fase do processo.

Após a seleção e a divisão dos sujeitos associados à pesquisa, o pesquisador realiza um período de observação do local a ser investigado. Assim, em hora e local previamente combinados com os sujeitos, o pesquisador realiza as filmagens dos protagonistas em situação concreta de atividade. Posteriormente, são selecionadas "[...] seqüências homogêneas, estritamente comparáveis por cada participante, escolhidas e montadas em função do conhecimento pelo pesquisador da atividade e das situações de trabalho" (Vieira; Faïta, 2003, p. 44), oportunizando, assim, a construção de um processo analítico da atividade inicial dos sujeitos envolvidos.

A realização das autoconfrontações simples e cruzada caracteriza, de certo modo, o início desse processo. Após as filmagens, o pesquisador seleciona as sequências mais significativas para serem analisadas pelos protagonistas. A autoconfrontação simples - fase composta por um pesquisador, por um protagonista, além do vídeo da atividade inicial - é o momento em que, separadamente, os protagonistas desenvolvem comentários sobre a sua atividade, a partir do filme da atividade inicial. Essa etapa é registrada em vídeo e, assim como a atividade inicial, compõe sequências que serão analisadas posteriormente.

A próxima etapa, autoconfrontação cruzada, é formada por um pesquisador, por dois protagonistas, além dos vídeos das atividades iniciais desses participantes, enriquecidas pelos comentários produzidos durante a fase anterior. Durante essa etapa, os protagonistas e o pesquisador (co)analisam a atividade e o discurso sobre a atividade produzida pelos participantes do estudo. A autoconfrontação cruzada, a autoconfrontação simples e a atividade inicial são registradas em vídeo e compõem o corpus analisado na última etapa da pesquisa.

\footnotetext{
11 No presente trabalho, adotamos a compreensão de Bendassolli (2011, p. 85-86), para quem “0 poder de agir tem a ver com a capacidade de o sujeito aumentar a amplitude de sua ação no trabalho, colocando em sua atividade elementos de sua própria subjetividade, demonstrando domínio e controle sobre instrumentos e ferramentas, e conseguindo responder à atividade do outro para conseguir realizar a sua própria".
} 
Finalmente, a derradeira etapa do processo - o retorno ao coletivo - caracteriza a conclusão das fases do quadro metodológico. Neste momento, todos os sujeitos associados à pesquisa, a saber, o pesquisador, os protagonistas do estudo e o coletivo de trabalho, (co)analisam a atividade inicial dos protagonistas, enriquecidas dos comentários produzidos nas fases simples e cruzadas. 0 retorno ao coletivo também é registrado em vídeo e compõe o corpus a ser analisado pelo pesquisador.

É imperativo destacar que o presente estudo, assim como os outros que, sob a égide da Linguística Aplicada, recorrem à autoconfrontação como quadro metodológico de análise, não toma como corpus de análise apenas a atividade inicial dos sujeitos, mas sim o que Vieira e Faïta (2003, p. 37) denominam de atividade sobre a atividade, em que a primeira corresponde à linguagem (discurso dos professores sobre a sua atividade inicial) e a segunda corresponde à atividade inicial (concreta) do trabalhador.

Passamos a seguir à metodologia empregada no presente estudo.

\section{METODOLOGIA}

Visto que neste estudo recorremos à parte do corpus da pesquisa de Lopes (2017), torna-se necessário traçar um panorama do referido estudo, o qual foi realizado no Núcleo de Línguas Estrangeiras (NLE), Campus Fátima, do Centro de Humanidades da Universidade Estadual do Ceará, e teve como objetivo principal analisar a atividade de professores estagiários, em aulas que abordam pontos civilizacionais no ensino de Francês como Língua Estrangeira.

Em relação aos sujeitos da pesquisa, houve dois grupos: o Grupo 1 (G1), formado por dois professores estagiários, protagonistas do estudo, e o Grupo 2 (G2), formado por 3 professores estagiários e pela professora coordenadora de língua francesa. Os componentes do G1 participaram de todas as fases que compõem o quadro metodológico empregado na pesquisa (ACS, ACC e RC). Os componentes do G2 participaram da última fase de produção de dados do estudo (RC).

Em seu estudo Lopes (2017) adotou alguns procedimentos e instrumentos de produção de dados. Inicialmente, foi empregado um questionário inicial (com os participantes do G1), que teve os objetivos de: a) traçar um perfil dos participantes; b) investigar a formação acadêmica dos estagiários; c) identificar de que maneira os estagiários organizam a sua atividade; e d) verificar se os professores estagiários compreendem a não vivência em países francófonos como um problema, ao ministrar aulas que abordam questões de civilização.

Após o emprego do questionário inicial, Lopes (2017) observou uma aula de cada protagonista. Além de tentar minimizar o desconforto dos protagonistas e dos alunos durante as filmagens, as observações tiveram, também, o intuito de: a) observar o estado físico da sala de aula onde seriam realizadas as gravações; b) verificar o posicionamento dos estagiários e de seus alunos em salas de aulas; e c) identificar o local mais adequado para posicionar as câmeras durante os registros.

Após as observações das aulas dos participantes do G1, o pesquisador iniciou as filmagens destas primeira fase do quadro metodológico. Esta etapa, de acordo com Vieira e Faïta (2003), corresponde à "primeira fonte de significações concretas" (Vieira; Faïta, 2003, p. 44, grifo dos autores). Após as filmagens, foram realizadas seleções, edições e gravações das sequências mais significativas da atividade inicial (aula registrada) dos professores estagiários, dando origem à segunda fase do quadro metodológico.

Após as fases de registro em vídeo da atividade e da seleção das sequências mais significativas para serem analisadas, o pesquisador realizou uma ACS com cada protagonista. Essa fase - composta pelo pesquisador, pelo protagonista e pelo filme da atividade inicial - correspondeu ao primeiro momento de contextualização, no qual os professores estagiários assistiram ao filme de sua atividade. Nessa fase, o pesquisador instaurou um espaço para que o sujeito autoconfrontado com sua atividade registrada produzisse um discurso explicativo-reflexivo sobre sua experiência vivida, realizando comentários sobre sua atividade inicial observada.

Após as ACSs, foi realizada a ACC, fase constituída pelos dois professores estagiários, pelos vídeos e comentários produzidos na fase anterior e pelo pesquisador. Essa etapa caracterizou um momento em que os protagonistas, além de analisarem o vídeo de sua atividade inicial e com os seus comentários sobre a referida atividade, defrontam-se, também, com a atividade e os comentários do outro protagonista da pesquisa. Caracterizando o que Vieira e Faïta (2003, p. 34) descrevem como um "espaço tempo [...] um momento de suspensão em que a referência se globaliza". 
O retorno ao coletivo contou com a participação dos professores estagiários, dos professores que representaram o coletivo de trabalho, do pesquisador, além do vídeo das sequências mais significativas das fases anteriores. Nessa fase, os dois grupos de participantes observaram e analisaram as sequências. Essa derradeira fase promoveu uma articulação dos discursos entre os participantes e trouxe para a discussão dificuldades, modos de fazer e dúvidas pertencentes ao coletivo de trabalho.

O último instrumento empregado foi um questionário final, no qual o pesquisador buscou analisar as impressões dos protagonistas após o processo dialógico-reflexivo da autoconfrontação.

Tendo contextualizado o estudo, a seguir, apresentamos dois excertos das fases da autoconfrontação provenientes do corpus da pesquisa de Lopes (2017) e, na sequência, traçaremos algumas análises, sobretudo, no que concerne aos anseios e às preocupações dos estagiários.

\section{RESULTADOS E DISCUSSÃO}

Desenvolvemos, na presente seção, as análises do corpus extraído da pesquisa de Lopes (2017), que, através do quadro metodológico da autoconfrontação, analisou aulas em que foram trabalhados aspectos de civilização no ensino de francês.

Os dois excertos, a seguir, correspondem aos discursos produzidos na fase cruzada do quadro metodológico. Esclarecemos que, antes das transcrições, existe uma breve contextualização das cenas observadas pelos protagonistas no momento das análises. As sequências numéricas, por sua vez, correspondem aos turnos de fala e, finalmente, as siglas P1, P2 e P, que representam, respectivamente, os discursos dos protagonistas (1 e 2) e do pesquisador. Destacamos que os excertos transcritos apresentam símbolos indicativos de aspectos linguísticos ou metalinguísticos ${ }^{12}$.

Cena 01: Em sala, o professor estagiário informa aos alunos que eles verão o vídeo sobre esporte na França que havia sido enviado para o grupo de WhatsApp durante a semana. 0 professor explica que ele e os dois alunos verão o vídeo no celular. Logo após alguns segundos, um aluno questiona o professor o significado de uma palavra.

153- P2: Então, a questão da civilização é por isso ++ (olha pra cima de forma pensativa) o que me deixa inseguro é:: é a falta do conhecimento. Você dominar e falar sobre a cultura francesa sem nunca ter ido até lá ou ter tido pouco contato, apenas pela internet, é: mu::ito mais complicado do que quem já foi, já viveu por algum tempo.

$[\ldots]$

157- P1: Eu fico pensando, essa questão da não vivência é meio++ é uma via de mão dupla. Ao mesmo tempo que eu acho que uma vivência na França é importante por ser uma experiência real, eu também acho que isso não pode dizer muita coisa. Eu tenho uma amiga que morou algum tempo na França, ela adora dar aula de civilização, por outro lado, ela afirma ter vá::rios problemas com a gramática. Quando eu vou dar aula de civilização e eu não sei alguma coisa ou que eu não vivenciei, eu pesquiso, vejo como é, pergunto aos outros professores, vejo vídeos e eu digo como é para meus alunos, a partir das respostas que eu encontro nas minhas pesquisas. É por isso que eu pesquiso e vou bem a fundo, eles (os alunos) pesquisam e depois dizem: "Olha professor, não é assim não." É por isso que eu vou bem a fundo nas minhas pesquisas sobre civilização.

Fonte: Adaptado de Lopes (2017, p. 187)

Evidenciamos, através do discurso de P2, que a falta de vivência em países francófonos caracteriza uma dificuldade em sua atividade. 0 protagonista aponta que essa não vivência é, justamente, a razão de sua insegurança ao trabalhar aspectos civilizacionais no ensino do francês. P2 afirma: Então, a questão da civilização é por isso ++ [...] o que me deixa inseguro é:: é a falta do conhecimento. Você dominar e falar sobre a cultura francesa sem nunca ter ido até lá ou ter tido pouco contato, apenas pela internet, é: mu::ito mais complicado [...].

\footnotetext{
12 As transcrições dos excertos realizadas Lopes (2017), estão apoiadas no modelo proposto Sandré (2013). Assim sendo, + ++ +++ caracteriza a pausa muito breve, breve ou média (respectivamente); : :: ::: corresponde ao alongamento de um som (o número de [:] sendo proporcional ao alongamento); [...] equivale ao corte feito pelo transcritor; (texto) equivale a comentário do transcritor.
} 
Por sua vez, P1 aponta os caminhos tomados para a solução dessa mesma dificuldade: Quando eu vou dar aula de civilização e eu não sei alguma coisa ou que eu não vivenciei, eu pesquiso, vejo como é, pergunto aos outros professores, vejo vídeos e eu digo como é para meus alunos, a partir das respostas que eu encontro nas minhas pesquisas. (157- P1). Percebemos que o estagiário recorre à experiência de outros colegas, além de outros recursos (vídeo), para superar essa dificuldade, respondendo, assim, às demandas dos alunos. 0 posicionamento de P1 reforça o discurso de Faïta (2004) que, ao descrever os professores iniciantes, afirma que estes "[...] teriam em comum o fato de compensarem - ou de tentarem compensar - a insuficiência transitória de sua capacidade de tratar de situações profissionais complexas mediante o desenvolvimento de recursos intermediários" (Faïta, 2004, p. 64) instaurado, assim, " [...] um quadro que torna possível a aprendizagem dos alunos, mas também a sua própria aprendizagem" (Saujat 2004, s/n)

Cena 02: Em sala, o protagonista fala aos alunos que eles realizarão exercícios de interpretação e produção textuais,

baseados em uma poesia cantada pela banda Coeur de Pirate. 0 professor distribui aos alunos o exercício com a letra da música e as questões. Após algumas leituras, os alunos ouvem a música e, no final, perguntam ao professor o significado de algumas palavras.

69- P1: [...] quando ele [um aluno] pergunta alguma coisa bem absurda em francês eu digo que eu não sei e que eu vou procurar em casa. Tem coisas que eu não sei em português, imagine em francês. [...] mas eu acho que ele faz isso para me testar. Você tem algum problema assim?

70- P2: Não, o meu problema é mais básico. É tipo meus alunos perguntarem alguma coisa que eu realmente não sei dizer. Na maioria das vezes eu pesquiso com antecedência as palavras, mas a minha memória é péssima, às vezes eles perguntam e eu não lembro, às vezes eu não sei mesmo o que quer dizer e aí++ eu fico com um constrangimento horrível.

[...]

73- P1: Quando eu erro uma expressão eu digo que não sei, peço que procurem em casa e digo que eu também vou procurar. Isso me faz ver que ele [o aluno] está me testando pois na outra aula ele não toca mais no assunto.

74- P: Não é algo que te deixe constrangido?

75- P1: Não, não, atualmente não, mas no meu primeiro semestre eu ficava, tipo, "meu Deus do céu, o que eu estou fazendo aqui?" Mas agora não.

76- P: É, porque o P2 disse que se sentia assim.

77- P2: É, não sei. Pra mim essas palavras que eles perguntam são palavras básicas e, na minha cabeça, eu acho que eu deveria saber e não sei. E aí, eu perco a:: a confiança deles sabe? E como se eles pensassem que eu não sei, tipo, "por que eu estou assistindo aula com um professor que não sabe?" Aí eu fico muito inseguro. [...]

Fonte: Adaptado de Lopes (2017, p. 191-192)

Neste excerto, observamos que os protagonistas falam sobre como eles se sentem ao serem questionados sobre o significado de uma palavra que eles desconhecem. Evidenciamos que os professores estagiários se mostram inseguros quando se veem obrigados a responder às perguntas "absurdas" feitas pelos alunos, fato que pode ser observado na afirmativa do P1, que declara se sentir "testado" por um aluno.

$\mathrm{O}$ desconforto provocado por essas situações fica mais evidente no discurso de P2 que afirma: [...] às vezes eu não sei mesmo o que quer dizer e aít+ eu fico com um constrangimento horrível. (70- P2). Compreendemos que esse sentimento está relacionado com a falta de experiência professoral do protagonista, uma vez que é esperado que o professor, por sua posição social, seja capaz de responder às questões propostas pelos alunos.

Em seguida, percebemos que P2, para descrever o seu sentimento de constrangimento, coloca-se na posição de aluno e enuncia o que, segundo ele, um aluno diria ao perceber que o professor não sabe responder a uma pergunta, revelando, assim, toda a insegurança e o medo que normalmente caracterizam os primeiros anos da profissão: E como se eles pensassem que eu não sei, tipo, "por que eu estou assistindo aula com um professor que não sabe?" Aí eu fico muito inseguro [...]. (77- P2).

O discurso do protagonista está em acordo com a descrição que García (2010) faz dos primeiros anos na carreira docente: "Um período de tensões [...] em contextos geralmente desconhecidos e durante o qual os professores iniciantes devem adquirir conhecimento profissional além de conseguir manter um certo equilíbrio pessoal" (García, 2010, p. 28). 
Assim, percebemos que as dificuldades apresentadas pelos protagonistas apontam para falta de uma expertise professoral. Em outros termos, "[...] a possibilidade de se servir de sua experiência para fazer outras experiências está no princípio do desenvolvimento da atividade e do poder de agir do professor"13 (Saujat, 2002, p. 116).

Em suma, destacamos que as dificuldades apresentadas discursivamente pelos protagonistas sobre a sua atividade, reveladas através do quadro metodológico da autoconfrontação, estão relacionadas às características de iniciantes dos estagiários. Ademais, observamos que, mesmo com todas as dificuldades, os protagonistas procuram instaurar um contexto de aprendizagem para eles mesmos e para os alunos, através da apropriação e da consolidação de seu próprio repertório didático-metodológico.

\section{CONSIDERAÇÕES FINAIS}

Acreditamos que tomar a atividade de professores estagiários como objeto de estudo, sobretudo como o aporte de dispositivos teórico-metodológicos que possibilitem reflexões críticas desses alunosprofessores, auxilia na compreensão dessa etapa na formação inicial docente. Embora os resultados deste estudo sejam provenientes de um contexto específico, acreditamos que as diferentes manifestações de insegurança reveladas nas verbalizações dos dois professores estagiários, durante as sessões de autoconfrontação, podem contribuir na formação inicial docente. Entendemos que, através do acesso às reflexões desses professores ao coanalisar sua atividade, outros estagiários podem passar a compreender que tais preocupações não devem ser encaradas como uma questão pessoal, individual, mas como algo comum naqueles que iniciam no métier.

\section{REFERÊNCIAS}

[1] Araújo, A. A. C. O trabalho docente no ensino de língua inglesa sob o olhar do formador e do formando: análise das relações dialógicas na atividade linguageira através do quadro teórico-metodológico da autoconfrontação. 2018. 744 f. Tese (Doutorado em Linguística Aplicada) - Programa de Pós-Graduação em Linguística Aplicada, Universidade Estadual do Ceará, Fortaleza, 2018.

[2] Bakhtin, M. Estética da criação verbal. São Paulo: Martins Fontes, 2011.

[3] Bendassolli, P. F. Mal-estar no trabalho: do sofrimento ao poder de agir. Revista Mal-estar e Subjetividade, Fortaleza, v. X, n. 1, p. 63-98, mar. 2011

[4] Bessa, L. P.; Silva; T. M.; Moraes, R. M. A. O ensino como trabalho: um novo olhar para a atividade do professor. Linguagem em Foco. POSLA/UECE, v.10. n.1, p. 93 - 104, 2018. Disponível em:<https://revistas.uece.br/index.php/linguagememfoco/article/view/1192>. Acesso em: 29 maio. 2019.

[5] Clot, Y. O trabalho e o poder de agir. Belo Horizonte: Fabrefactum, 2010.

[6] Caroly, S. Activité collective et réélaboration des règles: des enjeux pour la santé au travail. Sciences de l'Homme et Société. Université Victor Segalen - Bordeaux II, 2010. 269p. Daniellou, F. L'ergonomie en quête de ses principes. Toulouse: Octares Éditions, 1996

[7] Faïta, D. Gêneros do discurso, gêneros da atividade, análise da atividade do professor. In: Machado, A. R. (Org.). O ensino como trabalho: uma abordagem discursiva. Londrina: Eduel, 2004. p. 57-80.

[8] Garcia, C. M. O professor iniciante, a prática pedagógica e o sentido da experiência. Form. Doc., Belo Horizonte, v. 2, n. 3, p. 11-49, 2010. Disponível em:

<http://formacaodocente.autenticaeditora.com.br/artigo/download/20130327111753.pdf>. Acesso em: 20 ago. 2016.

[9] Huberman, M. 0 ciclo de vida profissional dos professores. In: Nóvoa, A. (Org.) Vidas de professores. Lisboa: Porto Editora, 1992. p. 31-61.

[10] Lopes, W. B. Prescrições e instrumentos na aula de civilização: análise da atividade docente de estagiários de FLE. 2017. 260 f. Dissertação (Mestrado Acadêmico em Linguística Aplicada) - Universidade Estadual do Ceará, Fortaleza, 2017.

[11] Moraes, R. M. A.; Magalhães, E. M. Abordagem clínica na análise da atividade docente: uma via unindo pesquisa, intervenção e formação. Horizontes, v. 35, n.3, p.105-120, 2017.

${ }^{13}$ No original: “[...] la possibilité de se servir de son expérience pour faire d'autres expériences est au principe du développement de l'activité et du pouvoir d'agir de l'enseignant". 
[12] Sandré, M. Analyser les discours oraux. Approche pluridisciplinaire. Série " discours et communication » dirigée par Dominique Maingueneau. Paris: Armand Colin, 2013.

[13] Saujat, F. Spécificités de l'activité d'enseignants débutants et "genres de l'activité professorale". Polifonia, n. 8, $2004 . \quad$ Não
<http://periodicoscientificos.ufmt.br/index.php/polifonia/article/view/1128/892>. Acesso em: 27 nov. 2015.

[14] Quand un professeur des écoles débutant instruit son "sosie" de son expérience. Les dossiers des sciences de l'éducation, n. 7, p. 107-117, 2002.

[15] Vieira, M.; Faïta, D. Quando os outros olham outros de si mesmo: reflexões metodológicas sobre a autoconfrontação cruzada. Polifonia, n. 7, p. 27-67, 2003. Disponível em: <http://cpd1.ufmt.br/meel /arquivos/artigos /230.pdf>. Acesso em: 29 jul. 2016.

[16] Vigotski, L. S. Pensamento e Linguagem. São Paulo: Martins Fontes, 2008.

[17] Wisner, A. Réflexions sur l'ergonomie. (1962-1995). Toulouse: Octares Éditions, 1995. 


\section{Capítulo 5}

\section{O estágio supervisionado no Ensino Fundamental I: Uma prática necessária}

\section{Ingrid Vasconcelos Ferreira \\ Maria das Graças Pereira Soares}

Resumo: 0 artigo intitulado 0 Estágio Supervisionado no Ensino Fundamental I: Uma pratica necessária, tem por finalidade refletir sobre as experiências desenvolvidas por meio da pratica do Estágio Supervisionado II pelos alunos do $7^{\circ}$ período de Pedagogia do Instituto de Ciências Sociais, Educação e Zootecnia (ICSEZ) da Universidade Federal do Amazonas (UFAM) no primeiro semestre de 2018, integrado ao Programa de Residência Pedagógica. 0 estágio realizou-se em uma escola municipal de Parintins-AM, considerando as seguintes etapas: Roda de conversa com os professores da Instituição e acadêmicos, para dialogar acerca dos objetivos e etapas do estágio, observação participante da pratica pedagógica do $3 \stackrel{0}{\circ}$ ano do Ensino Fundamental I, com registros no diário de campo e por último a regência. 0 estudo está fundamentado nos autores: Paulo Freire (1996), Tardif (2002), Augusto Cury (2003) e Gramsci (1968). O Estágio Supervisionado possibilitou ao estudante de licenciatura, o contato direto do professor em formação com a escola do Ensino Fundamental, contribuindo para relação teoria e prática, reflexões sobre a docência e o processo ensino aprendizagem dos alunos, ampliação de conhecimentos e habilidades que devem ser levados em consideração no processo de formação de educadores.

Palavras-chave: Contação de Histórias, Educação Infantil, Crianças, Aprendizagem. 


\section{INTRODUÇÃO}

O objetivo principal deste trabalho é relatar sobre a prática do Estágio Supervisionado II, realizado nos Anos Iniciais do Ensino Fundamental. A prática do estágio ocorreu em uma escola municipal de Parintins/AM no segundo semestre de 2018.

Para realização da prática do estágio, fez se necessário que os acadêmicos emitissem a documentação necessária para adentrar no espaço escolar, a entrega dessa documentação foi o primeiro passo para a formalização do processo. A princípio foi feita uma roda de conversa com os educadores da escola e acadêmicos de pedagogia, para apresentação dos objetivos e etapas do estágio, além de ouvir as expectativas dos educadores em relação ao Estágio Supervisionado.

Na semana seguinte, os estagiários adentraram o espaço escolar, para conhecer os processos pedagógicos realizados na biblioteca, secretaria, direção, coordenação pedagógica, Programa Mais Educação, observação participante na turma do $3^{\circ}$ ano, onde a estagiária ajudava em todas as atividades a professora de sala, como: leitura de histórias a cada início de aula, atividades escrita, além de uma atenção especial aos alunos com mais dificuldades, contribuindo com o processo de ensino aprendizagem, e por último a regência de classe à qual foi fundamental para pôr em pratica o conhecimento adquirido.

Esse artigo assim se organiza: no primeiro tópico apresentaremos a relevância do Estágio Supervisionado na formação inicial: A Práxis na Escola, no segundo tópico, Prática Pedagógica e Formação Inicial: Contexto, Reflexões e Diálogos, a partir das observações participantes, entrevistas e registros no caderno de campo; e no terceiro tópico, enfocaremos a Regência realizada na turma.

\section{METODOLOGIA}

Esta pesquisa caracterizou-se como bibligráfica e documental, de natureza qualitativa, com o objetivo de conhecer as influências da Contação de Histórias no processo de ensino e aprendizagem dos alunos. Para isso, utilizaram-se fontes secundárias como livros, artigos científicos e sites confiáveis. A entrevista semiestruturada foi utilizada para a coleta de dados. Como instrumentos de pesquisas utilizou-se o caderno de campo.

\section{DESENVOLVIMENTO}

\subsection{ESTÁGIO SUPERVISIONADO NA FORMAÇÃO INICIAL: A PRÁXIS NA ESCOLA.}

O Estágio Supervisionado nos Anos Iniciais proporciona ao estudante o domínio de mecanismos teóricos e práticos indispensáveis à execução de suas funções como docente. Buscamos, por meio dessa ação, vivenciar a experiência no contexto escolar e promover o desenvolvimento no campo profissional, a partir dos conhecimentos adquiridos durante o curso na instituição superior de ensino, bem como ampliar os conhecimentos adquiridos no campo de estágio. Assim, afirma Selma Garrido Pimenta:

Também, com frequência, se ouve que o estágio tem de ser teóricoprático, ou seja, que a teoria é indissociável da pratica. Para desenvolver essa perspectiva, é necessário explicitar os conceitos de pratica e de teoria e como compreendermos a superação da fragmentação entre elas a partir do conceito de práxis, o que aponto para o desenvolvimento do estágio como uma atitude investigativa, que envolve a reflexão e a intervenção na vida da escola, dos professores, dos alunos e da sociedade.

A escola, campo de estágio, foi uma instituição pública pertencente à rede municipal de Parintins-AM, está localizada na zona urbana da cidade Estado do Amazonas. Foi fundada em 21 de março de 1989 pelo Sr. Enéas de Jesus Gonçalves Sobrinho, prefeito na época e está inscrita sobre o Decreto-Lei no 90/99- PGMP, tem como entidade mantenedora a Secretaria Municipal de Educação e Desporto de Parintins - SEMED.

A referida escola está inserida num contexto sócio-político-econômico-cultural, cuja economia está baseada em pequenos comércios, pescadores, costureiras, tricicleiros, mototaxistas, carroceiros, agricultores, panificadores, marceneiros, artesões, funcionários públicos municipais, estaduais, federais e autônomos. No entanto, há um número expressivo de desempregados que constituem um dos problemas sociais mais graves e que muitas vezes só dependem dos programas do governo federal tais como, Bolsa Família. 
A população do bairro onde se localiza a escola em sua maioria é oriunda de comunidades rurais que migraram para a cidade em busca de melhores condições de vida e melhor educação para seus filhos. No entanto, o bairro não dispunha de infra-estrutura básica, com o passar dos anos foi ganhando serviços de água, luz, esgoto pavimentação e coleta de lixo diário. Hoje o bairro tem uma melhor estrutura que contribui para o bem estar de seus moradores.

A instituição no ano letivo de 2018 tinha 408 alunos matriculados nos turnos matutino e vespertino, atendendo o Ensino Fundamental de 1ำ ao 5ำ ano com 278 estudantes e no turno noturno a educação de jovens e adultos (EJA) de 6ํㅜ ao 9o ano com 130 estudantes.

Os alunos pertencem às famílias de baixa renda e que não possuem uma renda fixa, vale ressaltar que alguns convivem com pais separados, outros são criados por avós, tios e por pais que influenciam diretamente na educação. Há ainda alunos que passaram por situações traumatizantes, como abuso sexual, espancamento, ocasionando problemas sérios que influenciam negativamente na aprendizagem dos educandos.

De acordo com o Projeto Político Pedagógico da Instituição (PPP), e das observações realizadas a estrutura física da instituição é toda em alvenaria e possui 05 salas de aulas, 01 sala de Atendimento Educacional Especializado, 01 biblioteca, 01 diretoria, 01 secretaria, 01 sala de professores, 01 sala Coord. Pedagógica, 01 sala de informática, 01 cozinha, 01 dispensa 02 depósitos, 01 corredor, 05 banheiros, 03 salas (Anexo) para funcionar as oficinas do Programa Mais Educação e 01 área onde são realizadas as atividades recreativas.

A estrutura física de uma escola não se separa da pedagógica. É essencial que os alunos se sintam acolhidos, em um ambiente divertido, acolhedor e principalmente se sintam parte integrante do ambiente escolar, sendo importante a escola apresentar espaços variantes, que contribuam para a construção colaborativa de novos saberes, que favoreçam o desenvolvimento da autonomia e de habilidades cognitivas, afetivas, sociais e culturais. Ao planejar os ambientes na educação, devem-se levar em consideração as possibilidades de interações entre as crianças, já que ali é que permanecerão por um longo tempo.

É um desafio para as gestões municipais, a estrutura física das escolas publica, porém têm ocorrido avanços nos últimos anos, mas, infelizmente não chega a atender todas as necessidades das escolas. Nessa escola, por exemplo, os alunos tem ar condicionado em sala, os quais não funcionam, prejudicando o processo de ensino e aprendizagem, tendo em vista que nosso clima é bastante quente, principalmente no verão. O número de alunos que existe hoje numa sala de aula é de 40 alunos, o que é um problema já que as salas são pequenas.

A escola carece de um ambiente organizado e aconchegante, bem como uma quadra adequada para as crianças praticarem as atividades recreativas e culturais. Atualmente a escola dispõe de um espaço ao lado, sem cobertura, onde as crianças praticam atividades, por exemplo, em horários com temperatura elevadas. A escola possui espaço amplo, porém, pouco aproveitado, aonde esse espaço, possibilita a construção de hortas escolares, assim como parques para as crianças, que podem ser utilizados como recursos pedagógicos.

A Instituição pesquisada é aberta a toda população independente de renda familiar, pode-se observar a caracterização dos alunos, sendo muitos de bairros periféricos e de localidades mais carentes, muitas vezes chegam a escola sem fardamento ou com o mesmo sujo ou amassado e em algumas ocasiões alunos se queixam de fome por não ter comido nenhum alimento em casa.

Durante o período de observação, percebeu- se que as aulas ministradas pela professora regente despertavam o interesse nos alunos, pois ela procurava estratégias diversificadas para estimula-los, tornando as aulas menos cansativas. A turma em si era muito participativa, dedicada. Durante a apresentação dos conteúdos e das atividades, eles agiam espontaneamente, fazendo questionamentos, dando a sala de aula o seu verdadeiro significado, de uma escola criadora.

A escola criadora não significa escola de inventores e descobridores; ela indica uma fase e um método de investigação e de conhecimento, e não um programa predeterminado que obrigue à inovação e à originalidade $a$ todo custo. Indica que a aprendizagem ocorre notadamente graças a um esforço espontâneo e autônomo do discente, e no qual o professor exerce apenas uma função de guia amigável (...). Descobrir por si mesmo uma verdade, sem sugestões e ajudas exteriores, é criação (mesmo que a verdade seja velha) e demonstra a posse do método; indica que, de 
qualquer modo, entrou-se na fase da maturidade intelectual na qual se pode descobrir verdades novas (GRAMSCI, 1968, p. 124 e 124).

Observamos nesse processo que a professora da turma é comprometida, e tem um verdadeiro compromisso com sua turma. Os alunos a respeitavam e também mantinham uma relação de afetividade.

Freire, (1996, p. 30) destaca que "ensinar implica em respeitar os saberes dos educandos e não simplesmente transferir os conteúdos sem discutir o porquê daqueles conteúdos” [...], sabendo que essas atividades trabalham os movimentos livres e espontâneos do educando.

Conforme o PPP, o quadro funcional da instituição, atualmente está com 39 funcionários, sendo distribuídos da seguinte forma: 12 professores, 4 auxiliares de serviços gerais, 02 merendeiras, 01 coordenador pedagógico, 02 apoios pedagógicos, 04 auxiliares à docência, 02 professoras de AEE, 02 vigias, 01 auxiliar administrativo, 01 técnico de administração, 02 professoras de PPDA, 05 professoras de sala de leitura, 01 gestor. Atualmente no ano letivo de 2018, a escola está funcionando com 27 professores, 01 gestora, 01 coordenadora pedagógica, 01 secretaria, 02 merendeiras, 04 serviços gerais, 02 vigias.

\subsection{PRÁTICA PEDAGÓGICA E FORMAÇÃO INICIAL: CONTEXTO, REFLEXõES E DIÁLOGOS.}

As observações participantes da prática pedagógica realizaram-se em uma Turma de Ensino Fundamental I, $3^{\circ}$ ano, turno vespertino, composta de 29 alunos na faixa etária entre 11 a 12 anos de idade, os quais moram em bairros próximos e em bairros mais distante da escola, onde pode-se conhecer como os alunos se constituem como pessoas. Nesse processo, observamos que a maioria moram com os pais e avós, possui residência própria e ficam com parentes ou vizinhos quando os pais estão trabalhando. Desse modo, esses são responsáveis para busca- lós e levá-los na escola, outros utilizam o ônibus escolar e muitos vão sozinhos para casa.

Observamos ainda que as famílias dos alunos possuem uma renda baixa, girando em torno de 1 a 3 salários mínimos, sendo os pais autônomos, aposentados, atendentes, entre outros. Os alunos das famílias mais carentes, muitas vezes não dispõem de material escolar, fardamentos, o que causa uma situação muito desconfortável para o professor, pois ele necessita realizar atividades que precisam de materiais, porem eles não dispõem desses recursos.

A educação é um processo interativo, e é preciso compreender como os alunos se relacionam com o seu meio, e para isso o papel dos professores é de fundamental importância. "O "ser social" não nasce com o ser humano, ele desenvolve-se progressivamente, daí a importância da educação.” (DURKHEIM, 1965).

Desse modo, observamos na sala de aula, o trabalho da professora onde a cada início de semana realizava o plano de aula e trabalhava o conteúdo proposto, por meio de histórias, vídeos, atividades, provas, diálogos, diversificando os procedimentos metodológicos e o processo de avaliação da aprendizagem. Em meio a isso, notamos a falta de outras referências para realização do planejamento de ensino. A professora utilizava atividades pesquisadas na internet, buscando atender as necessidades da turma.

Ela mantinha um bom relacionamento com a turma, uma relação de respeito e confiança. Mostrou-se uma profissional comprometida com seu trabalho, e acima de tudo, amiga de seus alunos, pois conversava, tirava dúvidas, chamava atenção. Porém, existem alunos que precisavam de uma atenção maior, e observamos que ela não fazia ações planejadas para superar as dificuldades desses alunos, agindo como se os mesmos soubessem os conteúdos, as tarefas propostas, deixando-os na maioria vezes sem fazer nada em sala de aula, não exercendo o papel de uma escola cidadã, na qual desenvolve uma educação libertadora, onde o conhecimento como um processo de descoberta coletiva, mediatizada pelo educador e educando.

A educação é um processo longo e complexo, há muitas pedras no caminho de um educador, mas como conhecedores e preparados para os problemas, transformam essas pedras em novas possibilidades, e refletem esse espirito perseverante para sua turma.

Conforme Cury (2003, p.55) “educar é acreditar na vida, mesmo que derramemos lágrimas. Educar é ter esperança no futuro, mesmo que os jovens nos decepcionem no presente. Educar é semear com sabedoria e colher com paciência. Educar é ser um garimpeiro que procura os tesouros do coração". Para isso é imprescindível o desenvolvimento do estágio com consciência porque só assim o futuro professor terá a clareza do que ele enfrentará a cada dia, pois a pratica pedagógica requer um comprometimento social.

Constatamos que os conteúdos propostos são compatíveis com a série, alguns já estão até bem avançados. No 3ํano têm as seguintes disciplinas: Língua Portuguesa, Matemática, Geografia, História, Ciências, Artes 
e Educação Física. Todas as disciplinas são ministradas por uma professora, exceto Educação Física, que é ministrada por outro professor. 0 fato de ser somente uma professora para a maioria das disciplinas dificulta a organização do trabalho pedagógico, porque muitas disciplinas acabam ficando de lado, dando ênfase a Língua Portuguesa e Matemática. Apesar de Ciências ser uma disciplina que os alunos adoram, ela dava prioridade ao ensino de Língua Portuguesa. Observamos que os alunos desejavam estudar outras disciplinas, porem suas solicitações eram sempre adiadas. 0 ensino de Ciências é uma das áreas em que se pode reconstruir a relação ser humano/natureza em outros termos, contribuindo para o desenvolvimento de uma consciência social, planetária e crítica, onde infelizmente não acontecia na turma.

A professora seguia o planejamento, usando de sua criatividade e buscando meios para que os alunos realizassem as atividades propostas, pois a turma era muito participativa, necessitando de atividades diversificavas para estimula-los e não gerar conversas paralelas. A turma seguia uma rotina com atividades intensas, iniciando com o projeto deleite da leitura. Todos os dias as crianças iam para frente ler textos os quais eram retirados da caixa de leitura feita pela professora. Por meio de um microfone os alunos ficavam entusiasmados para ler, estimulando-os autonomia em suas atividades. Essa atividade contribuía para que eles se expressassem e participassem das atividades propostas.

Com tudo isso, a prática pedagógica é uma oportunidade de construção de saberes sobre o processo de ensino e aprendizagem dos alunos, bem como observar as diferentes experiências da docência. 0 processo de educar ultrapassa o simples ensinamento de conteúdo, mas revela-se no cuidar, compreender, se encantar nessa pratica.

\section{RESULTADOS E DISCUSSÃO}

\subsection{O PROFESSOR EM FORMAÇÃO NO COTIDIANO ESCOLAR: VIVÊNCIAS E ATUAÇÃO DOCENTE}

A regência como uma das etapas do Estágio Supervisionado, busca contribuir na formação das crianças ao mesmo tempo em que o acadêmico adquire novas experiências e habilidades com a arte da docência. Tudo começou com o planejamento da aula já que o "Planejar a atuação docente de uma maneira suficientemente flexível para permitir a adaptação às necessidades dos alunos em todo o processo de ensino; aprendizagem". (ZABALA, 1998, p 92)

No decorrer da prática do estágio, obtivemos orientações sobre a regência, tendo assim o estagiário a oportunidade de desenvolver uma pratica pedagógica interdisciplinar, com apoio do orientador de estágio e o professor supervisor da unidade concedente. Tardif (2002) enfatiza que o Estágio Supervisionado constitui uma das etapas mais importantes na vida acadêmica dos alunos de licenciatura

A metodologia utilizada fora baseada em exibição de vídeo, jogos didáticos, contação de história, diálogos e atividades escritas.

Devido à regência ser realizada no mês de outubro, mês das crianças, o título foi "Conhecendo os direitos da Criança", onde se procurou apresentar de maneira lúdica os direitos das crianças, a partir do Estatuto da Criança e do Adolescente.

A regência iniciou-se com as atividades de rotina, seguida da exibição do vídeo "0 direito das crianças" o qual tratava sobre os direitos das crianças. Após apresentação do vídeo houve questionamentos aos alunos para saber sobre os conhecimentos prévios a cerca da temática. As falas dos alunos foram registradas em cartolina e fixadas na parede, para que todos pudessem ter acesso às informações. Apos esse momento, a estagiaria explicou a importância em conhecer os direitos, fazendo uma retomada a partir com dos combinados da turma, com relação aos direitos e deveres no interior da escola.

Feito isso, realizou-se a leitura compartilhada através de slides acerca dos direitos da criança e do adolescente por meio da história em quadrinho da turma da Mônica que trata sobre o Estatuto da Criança e do Adolescente- ECA, como demostram as figuras 1 e 2 . 
Figura 1. Aula de regência Figura 2. Aula de regência
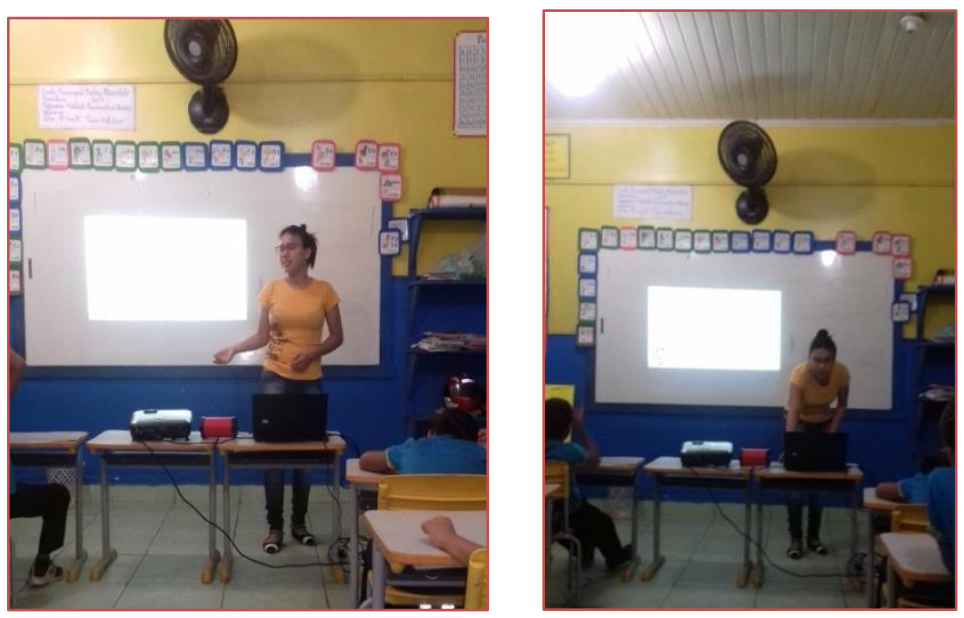

Fonte: Vasconcelos, 2018

Gilberto Freyre foi um dos maiores defensores dos quadrinhos no Brasil, classificava-os como uma "ponte para a literatura" recursos que os professores podem trabalhar a leitura crítica, interpretação de texto, criatividade, ortografia e muitas outras atividades, sendo uma forma de fixar os conteúdos para os alunos.

Durante a leitura em quadrinhos, os alunos fizeram muitos questionamentos a respeito dos direitos das crianças. Eles contaram situações vividas em seus lares que se relacionavam com o tema, deixando a aula participativa e prazerosa à professora/estagiaria pode observar que o resultado foi bem significativo.

A regência sempre gera ansiedade e nervosismo para os professores em formação, ao fim da aula é como se colhesse os frutos de um trabalho que foi dedicado, pensado e articulado com carinho para os alunos, com ajuda da orientadora, e a professora da unidade concedente, tudo ocorreu bem.

Ao final da regência, percebe- se que o papel do professor é se dedicar ao máximo no que puder para oferecer aos alunos praticas significativas. Os alunos fizeram muitos questionamentos, e podemos constatar a aprendizagem do conteúdo que foi trabalhado de forma dialógica, possibilitando a motivação, participação e reflexão no desenvolvimento da aula, conforme demostra as figuras 3 e 4.

Figura 3. Exposição da atividade

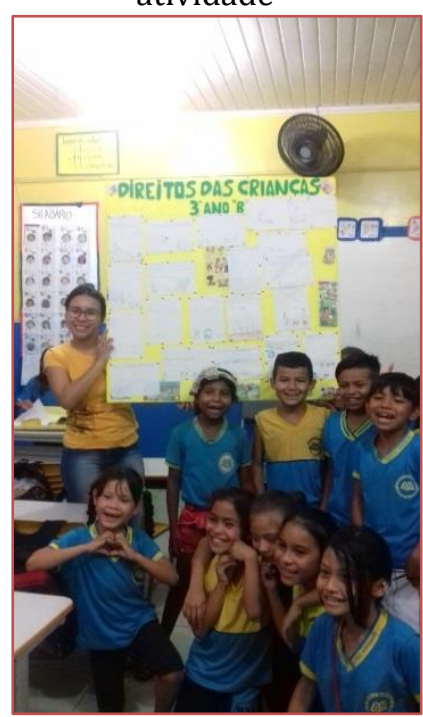

Figura 4. Exposição da atividade

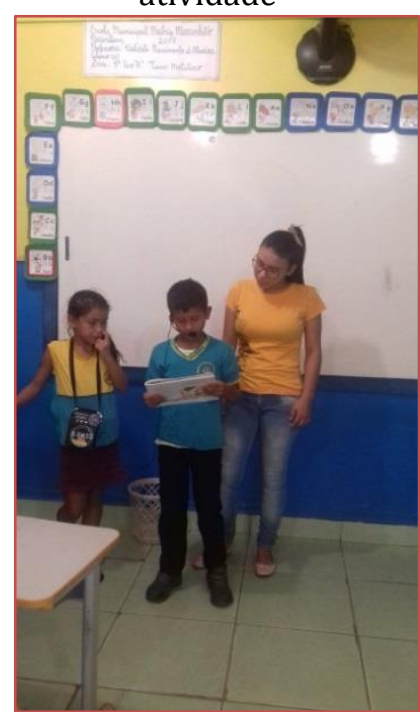


Ensinar é uma arte que precisa ser prazerosa, o educador precisa ser critico, sendo assim, sabe que o trabalho escolar, é, ao mesmo tempo, pedagógico, psicossocial e sociopolítico, cabendo promover uma educação de integração. Portanto acredita-se que tenha sido uma aula com atividades satisfatórias, com contribuição dos alunos, que desenvolveram com muita afinidade as atividades propostas. Percebeu-se grande entusiasmo da turma, tornando as atividades ainda mais interessantes.

Os alunos fizeram indagações e discussões a respeito da regência nas aulas seguintes, e muitos pediram aos pais para lerem o Estatuto Criança e do Adolescente completo e atualizado, que foi uma orientação da professora/estagiaria. Concluímos que a prática de ensino motivadora, que desperta os interesses dos alunos envolve: compromisso, planejamento e conhecimento por parte do educador.

O período de convivência com a turma foi suficiente para criar laços afetivos fortes, entre educador e educando. Os alunos as são capazes de amar com facilidade, sutilmente, e é um amor puro, que faz diferença no processo de ensino e aprendizagem. A profissão de professor vai além de saber planejar, ser inteligente, mas principalmente fazer com amor e por amor. A educação escolar deve ter uma pespectiva integradora, integração esta que resultarão os princípios de um novo projeto do fazer pedagógico. Com isso, ao final do período de estagio, os alunos se sentiram muito tristes com a despedida da professora/estagiaria, houve choros, e como despedida, os mesmos tomaram iniciativa para escreverem cartas para a professora/estagiaria, que ficou emocionada e feliz com o trabalho realizado, como demonstra a figura 6.

Figura 6. Cartas confeccionadas pelos alunos

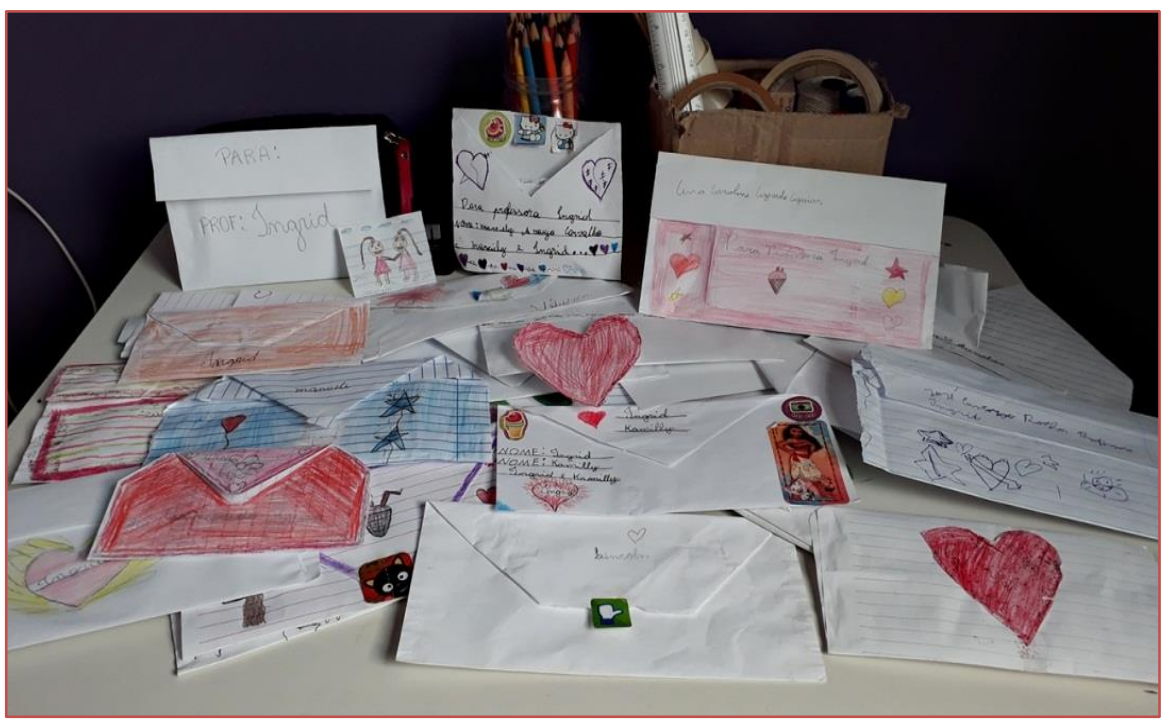

O Estágio Supervisionado é uma prática que oportuniza ao professor em formação ter contato direto com o contexto escolar, articulação teoria e pratica, pesquisa e ampliação de saberes proporcionando aos acadêmicos as implicações da profissão, o ato de ensinar e tudo que o envolve, fazendo-os assim, refletir sobre a docência, aprimorando sua capacidade criativa e sua análise crítica através da ação- reflexão- ação, elemento fundamental para a formação.

\section{CONSIDERAÇÕES FINAIS}

O Estágio Supervisionado é um desafio para todos os acadêmicos das áreas de licenciaturas, porém é um momento satisfatório que permite a oportunidade de conhecer a realidade escolar em seus diferentes aspetos, assim como também as dificuldades enfrentadas pelos professores e alunos. Podemos perceber a práxis no contexto do ensino fundamental e conhecemos as necessidades dos estudantes, educadores como também dos demais profissionais envolvidos no processo educativo.

Tendo em vista que a escola é um ambiente de aprendizagem, todo o trabalho desenvolvido no estágio foi relevante, pois passamos a conhecer de forma geral o papel da docência, bem como o processo ensino aprendizagem dos alunos. A escola, campo de estágio, precisa eventualmente de alguns ajustes desde o seu espaço físico estrutural, como em ampliação do quadro de profissionais, rotina diversificada, 
ampliação de ambiente, recursos materiais, fortalecer as relações entre os profissionais, mais apoio familiar, estratégias para os problemas de indisciplina dos alunos, entre outros, porém os educadores e demais profissionais buscam superar os desafios encontrados na perspectiva da formação integral dos alunos.

Desse modo, a prática docente deve ser refletida a cada dia, a cada atividade desenvolvida para que assim possa evoluir e contribuir para que o acadêmico tenha o embasamento e habilidades necessárias para ser um profissional atuante e possa melhor perceber o que irá enfrentar em sua carreira, tendo mais segurança e constituindo-se como professor comprometido com a educação.

\section{REFERÊNCIAS}

[1] CURY, Augusto. Pais brilhantes, professores fascinantes: A educação inteligente; formando jovens educadores e felizes. Rio de Janeiro: Editora Sextante, 2003.

[2] FREIRE, P. (1996). Pedagogia da Autonomia: saberes necessários à prática educativa. 19. ed. São Paulo: Paz e Terra.

[3] GRAMSCI, Antonio. Os intelectuais e a organização da cultura. Rio de Janeiro: Civilização Brasileira,1968.

[4] PIMENTA, Selman Garrido. Estágio e docência. Selma Garrido Pimenta, Maria Socorro Lucena Lima; revisão técnica Jose Cerchi Fusari. 4 ed. São Paulo: Cortez, 2009. Revista Gestão Escolar, Acessado em 13 de junho de 2018. Disponível em: gestaoescolar.abril.com.br

[5] TARDIF, Maurice. Saberes docentes e formação profissional. Petrópolis: Vozes, 2002.

[6] ZABALA, Antoni. A pratica educativa: como ensinar. Tradução Ernani F.da F. Rosa- Porto Alegre: Artmed, 1998. 


\section{Capítulo 6}

\section{Contribuição da residência pedagógica para a formação inicial de professores}

\section{Cicera Simone Santos de Farias}

Nataliana dos Santos Oliveira

Eugênia Cruz Pinheiro

Josefa Nunes Pinheiro

Carlos Leonel de Alencar

Resumo: 0 programa de residência pedagógica possui como finalidade aperfeiçoar a formação inicial docente articulando a capacidade de relacionar as teorias aprendidas na universidade com a prática docente no espaço escolar. Este artigo tem por propósito identificar a contribuição que a residência pedagógica pode proporcionar a formação inicial dos futuros professores. Os caminhos percorridos pela presente investigação possuem características de caráter qualitativo, baseando-se, principalmente, em estudos bibliográficos. A Residência Pedagógica foi instituída para superar a tradicional distância entre a teoria e a prática docente, através da vivencia mais ampla e de uma ação compartilhada entre a universidade, os discentes em formação e a escola. Por possuir uma carga horária ampla, contribui para o que o futuro professor passe a conhecer e vivenciar o ambiente escolar de uma forma mais aprofundada. 0 programa também possibilita que discentes possam trocar conhecimentos com os preceptores no período da regência, em que o discente tanto terá auxílio como a troca de experiência com os preceptores na orientação das atividades. A formação dos professores consiste em uma das principais técnicas para preparar os alunos na atuação nas escolas, sendo necessário que os docentes tenham oportunidades de constante atualização e qualificação para desenvolver o seu trabalho, capacitando assim, profissionais que sejam agentes de transformações, podendo atuar de forma crítica e reflexiva na ação pedagógica. 


\section{INTRODUÇÃO}

A formação inicial de professores trata da preparação para desempenhar a profissão, sendo o período de transição de discente do curso de licenciatura, para a docência. É fundamental que essa fase que abrange a etapa de formação inicial seja vista como a base para a instrução contínua do futuro docente.

Segundo Lima (2007), a formação inicial de professores não se trata apenas da obtenção da certidão legal para exercer a atividade docente, mas sim, espera-se que a formação inicial ajude a desenvolver as habilidades, valores, atitudes e conhecimentos que vão construir permanentemente seus saberes, sua identidade.

De acordo com Pimenta e Lima (2012), o primeiro contato como professor ocorre a partir dos estágios supervisionados, sendo o momento em que as teorias aprendidas na universidade são associadas à ação pedagógica.

Porém, a carga horária de imersão dos estágios supervisionados é curta, o que dificulta o estagiário conhecer a fundo o ambiente escolar. A existência de programas voltados para a formação inicial com um período maior de tempo é uma das alternativas que possibilitaria a chance de se conhecer e atuar com mais eficiência no âmbito escolar, tendo assim uma visão mais ampla da cultura escolar, um exemplo disto é a Residência Pedagógica.

É pelo Programa da Residência Pedagógica que o discente em formação adquire saberes pertinentes à profissão que estarão próximos da realidade escolar, pois a residência possui uma carga horária mais extensa em que é possível se construir conhecimentos técnicos e práticos que só seriam adquiridos após a formação inicial. Tendo ainda a aproximação entre Universidade e o espaço escolar (CAPES, 2018).

Dessa maneira a problemática que percorre esse estudo é saber qual a contribuição da residência pedagógica para a formação inicial dos professores.

Este estudo teve início numa pesquisa bibliográfica, discutindo a partir dos estudos de Mota, De La Torres e Barrios, Moretti, dentre outros autores que possuem afinidade com o assunto tratado.

Os motivos desse estudo justifica-se por sermos discentes do curso de licenciatura em História, e pelo fato de uma das pesquisadoras ser residente do Programa de Residência Pedagógica. A relevância desse estudo é contribuir com futuras pesquisas cientificas acerca do tema em questão.

\section{METODOLOGIA}

Este estudo ocorreu através de uma pesquisa bibliográfica, que segundo Fonseca (2002) é realizada a partir de levantamento de referências teóricas já analisadas, e publicadas por meios escritos e eletrônico, como artigos científicos, monografias, livros, páginas de web sites entre outros. 0 objetivo é recolher informações ou conhecimentos prévios sobre o problema a respeito do qual se busca resposta.

Partindo de uma abordagem qualitativa que se dispõe a trabalhar com o universo de significados, crenças, motivos, aspirações, valores e atitudes, correspondendo a um espaço amplo das relações dos processos e dos fenômenos sociais.

\section{RESULTADOS E DISCUSSÃO}

O conceito de formação possui mais de um sentido. Para De La Torre e Barrios (2002, p. 14) formar é "ajudar a tomar consciência das próprias atuações e como melhorá-las". Os autores ainda relatam que as experiências que se adquirem na formação inicial auxiliam na construção da identidade profissional, isto é, o momento em que acabamos descobrindo o tipo de professor que queremos ser, pois descobrimos na prática os medos, receios e vitórias que a profissão em questão traz consigo, tendo assim a interação entre as experiências individuais e profissionais. Identidade é compreendida aqui como um processo em construção de um indivíduo.

[...] uma construção social marcada por múltiplos fatores que interagem entre si, resultando numa série de representações que os docentes fazem de si mesmos e de suas funções, estabelecendo, consciente ou inconscientemente, negociações das quais certamente fazem parte de suas histórias de vida, suas condições concretas de trabalho, o imaginário recorrente acerca dessa profissão [...] (GARCIA; HYPÓLITO; VIEIRA, 2005, p. 54-55). 
Os estágios curriculares supervisionados são o eixo central da formação inicial. Segundo Pimenta e Lima (2012) os estágios são necessários, pois é a partir deles que o aluno colocará em prática as teorias desenvolvidas no curso de formação permitindo ao futuro docente conhecer, analisar e refletir sobre o ambiente escolar. No entanto, apesar dos estágios auxiliarem na formação inicial, estes possuem um período curto de imersão sendo fundamental a existência de projetos, programas que beneficiem os futuros docentes, a exemplo disto, temos o Programa de Residência Pedagógica, que via de regra:

[...] consiste na imersão planejada e sistemática do aluno de licenciatura em ambiente escolar visando à vivência e experimentação de situações concretas do cotidiano escolar e da sala de aula que depois servirão de objeto de reflexão sobre a articulação entre teoria e prática. Durante e após a imersão o residente deve ser estimulado a refletir e avaliar sobre sua prática e relação com a profissionalização do docente escolar, para registro em relatório e contribuir para a avaliação de socialização de sua experiência como residente (CAPES, 06/2018, p. 1).

Uma das contribuições da residência pedagógica é oportunizar aos discentes uma aproximação com a realidade das escolas, espaço este em que serão adquiridos saberes que auxiliarão na carreira docente, pois segundo Silva, (2015) a residência pedagógica por se basear no princípio da imersão ela "[...] proporciona ao estudante (residente) tempo integral e ininterrupto de vivência na realidade escolar, sob a tutela de um professor formador". A autora ainda afirma que o programa, não contempla apenas a sala de aula, sendo possível ao discente desvendar as diferentes vertentes da escola, como o acompanhamento pedagógico e a convivência com o espaço escolar.

Dessa maneira, o discente do curso superior torna-se parte da realidade escolar e não apenas um mero expectador. [...] "Trazendo voz e vez para suas concepções e experiências no cotidiano escolar, permitindo assim que os conhecimentos apreendidos nas salas da universidade sejam colocados em prática" (SILVA, 2015. p.25). Porém, é importante ressaltar que, para que ocorra o desenvolvimento do programa de residência pedagógica se dê de maneira eficaz é necessário que haja uma relação de confiança e suporte entre a escola, universidade e discente residente (SILVA, 2015).

A Residência Pedagógica apresenta algumas características particulares tornando-a a diferenciada, por exemplo, carga horária mais extensa, permitindo assim uma imersão na escola e sala de aula por um tempo mais prolongado, podendo assim fazer com que o bolsista enxergue o cotidiano escolar em sua totalidade (PANNUTI, 2015). "A residência pedagógica terá o total de 440 horas de atividades [...] sendo 100 horas de regência, que incluirá o planejamento e execução de pelo menos uma intervenção pedagógica" (CAPES, 06/2018, p.1-2). 0 programa, no geral, visa, entre outros objetivos:

I. Aperfeiçoar a formação dos discentes de cursos de licenciatura, por meio do desenvolvimento de projetos que fortaleçam o campo da prática e conduzam o licenciando a exercitar de forma ativa a relação entre teoria e prática profissional docente, utilizando coleta de dados e diagnóstico sobre o ensino e a aprendizagem escolar, entre outras didáticas e metodologias;

II. Induzir a reformulação do estágio supervisionado nos cursos de licenciatura, tendo por base a experiência da residência pedagógica;

[...]

IV. Promover a adequação dos currículos e propostas pedagógicas dos cursos de formação inicial de professores da educação básica às orientações da Base Nacional Comum Curricular (BNCC) (CAPES,06/2018, p. 1).

Desse modo, podemos dizer que o programa propõe objetivos para aperfeiçoar, induzir, fortalecer e promover a formação adequada, consolidando a relação entre as universidades pública e as escolas, propondo a vivencia profissional na educação básica.

O Programa da Residência Pedagógica desenvolve duas etapas, a primeira está relacionada à observação do campo de atuação e o segundo momento às regências, tendo ainda como auxilio a troca de experiência com os preceptores na orientação das atividades a serem desenvolvidas. Para Mota et al., (2018), essas etapas do programa são fundamentais, pois é nessa fase que vão ser adquiridas as devidas noções complementar de conhecimento prático dos licenciados, e ressalta que a residência pedagógica é idealizada como um direito do discente em formação, pois o programa possibilita um campo de conhecimento mútuo. 
Pois, “[...] ao mesmo tempo em que o professor da escola dispõe-se a receber o estudante da graduação em sala de aula, ele tem a oportunidade em contra partida de participar de ações de formação continuada" (MORETI, 2011, p. 390).

Portanto, a Residência Pedagógica tem um papel positivo, pois por ela são experimentados e vivenciados acontecimentos e atividades que somente professores já formados vivenciariam, trazendo assim contribuições para se formar uma postura profissional voltada também para o diálogo e coletividade, podendo ampliar os conhecimentos tanto do discentes quanto dos docentes.

\section{CONSIDERAÇÕES FINAIS}

A Residência Pedagógica foi instituída para superar a tradicional distância entre a teoria e a prática docente, pela vivência mais ampla e de uma ação compartilhada entre a universidade, os discentes em formação e a escola. Por possuir uma carga horária ampla, contribui para o que o futuro professor passe a conhecer e vivenciar o ambiente escolar de uma forma mais aprofundada. 0 programa também possibilita que discentes possam trocar conhecimentos com os preceptores no período da regência, em que o discente tanto terá auxílio como a troca de experiência com os preceptores na orientação das atividades.

Conclui-se que a Residência Pedagógica contribui de maneira positiva para a formação inicial de professores, sendo uma das alternativas para a melhoria da formação dos futuros docentes na educação básica. Destacando que há necessidade de mais pesquisas cientificas voltadas para esse tema em questão, pois as discussões das concepções acerca de uma formação inicial adequada são amplas e questionadoras, na busca de alternativas para um ensino público de qualidade.

\section{REFERÊNCIAS}

[1] De La Torres, e.; Barrios, Ó. Curso de Formação para Educadores, São Paulo, Madras Editora Ltda., 2002.

[2] Capes, Edital 06/2018. Programa de Residência Pedagógica: chamada pública para apresentação de proposta no âmbito do Programa de Residência Pedagógica. Disponível em: https://www.capes.gov.br/images/stories/download/editais/01032018-Edital-6-2018-Residencia-pedagogica.pdf

[3] Fonseca, J. J. S. Metodologia da pesquisa científica. Fortaleza: UEC, 2002. Apostila.

[4] Garcia, M. M. A.; Hypolito, A. M.; Vieira, J. S. As identidades docentes como fabricação da docência. Educação e Pesquisa. São Paulo, v.31 n.1, pp.45-56, jan./mar, 2005.

[5] Lima, V. M. M. Formação do professor polivalente e saberes docentes: um estudo a partir de escolas públicas. 2007. 280 f. Tese (Doutorado em Educação) - Faculdade de Educação, Universidade de São Paulo, São Paulo, 2007.

[6] Minayo, M. C.S. (org.). Pesquisa Social. Teoria, método e criatividade. 18 ed. Petrópolis: Vozes, 2001.

[7] Moretti, V. D. A articulação entre a formação inicial continuada de professores que ensinam matemática: o caso da Residência Pedagógica da Unifesp. Educação, vol. 34, no 3 p. 385- 900set/dezembro, 2011.

[8] Mota, A. S.; Oliveira, B. K. S.; Costa, F. F.; Rocha, J.A. A; Reis, M. A.; Paiva, T. D. Residência Pedagógica: uma contribuição para a formação inicial de professores. VII ENALIC, 2018.

[9] Panntin, M. P. A relação teoria e prática na Residência Pedagógica. 2015.

[10] Pimenta, S. G.; Lima, M. S. L. Estágio e docência. São Paulo: Cortez, 2012.

[11] Silva, Residência Pedagógica: Uma alternativa possível na formação inicial de professores de Ciências e Biologia na UFPR? 2015. 78f. (Trabalho de Conclusão de Curso em Ciências Biológicas). Universidade Federal do Paraná, Curitiba, 2015. 


\section{Capítulo 7}

(Trans)formação docente: Programa residência pedagógica na formação inicial de professores

Bianca Bezerra Leandro

Ana Mercia Dantas de Oliveira Felix

Francisca Eliane da Rocha

Paula Ivani Medeiros dos Santos

Resumo: 0 trabalho tem como objetivo geral analisar a importância do programa residência pedagógica (PRP) na formação profissional docente na relação teoria e prática do curso de licenciatura em Biologia do IFRN campus Macau. Nesse contexto, o trabalho apresenta relatos de experiencias que alunos residentes do PRP obtiveram até o presente momento, abordando a importância desse programa na formação inicial. Para a realização desse trabalho foram utilizados como referenciais teóricos: o Edital Capes $n^{0}$ 06/18, portaria $n^{0}$ 38, de 28 de fevereiro de 2018, Projeto Institucional Registrado na Plataforma Freire, subprojeto da licenciatura em Biologia, e o Projeto Político do Curso superior de licenciatura em Biologia. Esses documentos forneceram a compreensão e a objetividade do programa como um todo e em específico no IFRN-campus Macau. A partir desta pesquisa podemos identificar que o PRP é uma das ações que integram a política nacional de formação de professores e busca o aperfeiçoamento do estágio curricular supervisionado ao promover a imersão do licenciando nas escolas de educação básica no decorrer de sua formação. Desta forma, o programa dispõe dos discentes dos cursos de licenciaturas e propõe uma reformulação do estágio supervisionado, visto que, diante de relatos, o programa permite ao licenciado um convívio maior com a teoria de a prática docente.

Palavras-chave: Residência Pedagógica; Estágio Supervisionado; Formação de professores. 


\section{INTRODUÇÃO}

A educação sempre teve uma reponsabilidade significativa perante a sociedade, desde então se vêm debatendo, pensando e defendendo em como deve ser a formação profissional de professores, seja ela inicial ou continuada. Porém, sabe-se que ainda temos muito o que progredir em nossas políticas de formação de professores, principalmente no que se diz respeito aos cursos que os formam, nos quais deveria estar garantida uma melhor conexão entre teoria e prática. No entanto, há ainda uma certa distância entre essas duas vertentes, e para fazer uma ponte entre as duas, há a necessidade de formulações de programas que possibilitem aos alunos dos cursos de licenciatura, no decorrer de sua formação, a experiência com a realidade da prática de ensino.

Mediante o exposto, foi despertado o interesse de refletir sobre, como o programa Residência Pedagógica (RP) pode contribuir no processo de formação inicial de professores no curso de licenciatura em biologia do IFRN campus Macau, enfatizando a importância da articulação entre teoria e prática. Também busca-se com esse trabalho relatar as contribuições do RP para a formação do licenciando até o momento de realização desse estudo.

\section{METODOLOGIA}

O trabalho foi desenvolvido por alunos do curso de licenciatura em Biologia no IFRN/campus Macau juntamente com o preceptor e a coordenadora. A metodologia ultilizada é o relato de experiencia de residentes sobre algumas etapas do programa que foram vivenciadas até o momento. Etapas essas que partem um cronograma de atividades pré- definidas a serem desenvolvidas num total de 440 horas.

As etapas estão distribuídas da seguinte forma: primeiro a formação, conhecimento e gestão de competências, através de cursos com carga horaria de $60 \mathrm{~h}$, a distância com vídeo- aulas de formação de preceptores e de preparação dos residentes para o programa fornecidos pela coordenação institucional do IFRN e encontros periódicos entre os participantes, com a finalidade de discutir a dinâmica de realização do programa, e a apropriação do embasamento teórico para sua realização; ambientação na escola (60 horas) com apresentação dos residentes nas escolas e elaboração do plano de ação a ser desenvolvido nas escolas campo, estudos do contexto educacional/diagnóstico da realidade escolar e sociocultural dos alunos, bem como seus níveis de aprendizagens; observação e análise das atividades de ensino desenvolvidas pelos professores preceptores e demais professores formadores; 320 horas de imersão, sendo 100 de regência de classe, que incluirá a elaboração coletiva do planejamento de ações através de reuniões para definição das ações didático-pedagógicas com execução de pelo menos uma intervenção pedagógica, articulando as ações do plano de trabalho do subprojeto de biologia às ações de planejamento das escolas-campo com sequências didáticas baseadas na análise do contexto escolar, considerando as condições objetivas e subjetivas do processo de ensino-a prendizagem e 60 horas destinadas à elaboração de relatório final, avaliação e socialização de atividades.

\subsection{INÍCIO DA FORMAÇ̃̃O DOCENTE E O ESTAGIO SUPERVISIONADO}

Graças ao desenvolvimento de diversos programas de formação docente, pode-se notar grandes avanços dessa área nos últimos tempos. Porém, ainda há muitos desafios frente as políticas governamentais, desafios esses existentes também nas práxis de formação das instituições. Nessas instituições formadoras, de modo geral, "o cenário das condições de formação dos professores não é animador pelos dados obtidos em inúmeros estudos e pelo próprio desempenho dos sistemas e níveis de ensino". (Gatti, 2016)

Logo, se faz necessário uma revisão e renovação desse quadro de formação docente atual e isso não é uma tarefa fácil. Visto que, segundo Gatti (2016), poucas instituições se propõem a um papel de iniciativas inovadoras, e os avanços que permitem o licenciando enfrentar uma carreira docente consistente de saberes e conhecimento, fica restrito apenas a essas instituições.

Segundo Souza (2009), o início da formação docente é marcado por uma fase de crises e dificuldades de enfrentamento, logo, pode-se dizer que é um dos períodos de bastante importância para a carreira profissional de um docente, pois vai determinar como possivelmente será seu perfil de docente e sua relação com o pratica docente profissional. Considerando isso, faz-se necessário uma preparação do licenciando pautada não somente na teoria, mas também na prática. Na maioria dos cursos de licenciatura essa preparação é feita através de estágios supervisionados. De acordo com o Projeto Político Pedagógico do IFRN: 
O estágio curricular supervisionado, tido como prática profissional obrigatória, é realizado por meio de estágio docente. Esse tipo de estágio é considerado uma etapa educativa necessária para consolidar os conhecimentos da prática docente. Proporciona, aos alunos dos cursos de licenciatura, aprofundamento nas reflexões tanto sobre o processo de ensino e aprendizagem quanto sobre as relações e as implicações pedagógico-administrativas do ambiente escolar. (BRASIL, 2012)

De modo geral, esse estágio constitui-se em um processo de articulação entre teoria- prática. De acordo com o Projeto Pedagógico do Curso Superior de Licenciatura Plena em Biologia (2009), o Estágio Curricular Supervisionado deverá ser desenvolvido a partir do início do 5o período do curso e terá duração mínima de 400 (quatrocentos) horas, sendo que essas horas serão destribuidas no decorrer de 4 (quatro) etapas e apenas nas duas ultimas é a que o licenciando vai para regência em sala de aula, tendo que cumprir 20h/aulas em uma turma de ensino fundamental e $20 \mathrm{~h} /$ aulas em uma turma de ensino médio. 0 Estágio é acompanhado por um Professor Coordenador de Estágios e um Professor Orientador, que irão avaliar o aluno.

Pereira (2007) traz uma reflecção a respeito da realidade brasileira dos estagios supervisionados e afirmam que "os estágios supervisionados e as práticas de ensino ocupam espaços pouco prestigiados nos currículos: em geral, aparecem bastante tardiamente nesse percurso, alimentando a ideia de que chegou a hora de aplicar os conhecimentos aprendidos (ou supostamente aprendidos) por meio das disciplinas de conteúdo específico e/ou pedagógicos." Logo, podemos dizer que, diante dessa realidade há uma necessidade de propor uma estratégia que permita, ao licenciando, incorporar a prática na sua formação. Alguns programas surgem com esse objetivo, como por exemplo o PIBID, que um dos seus objetivos é "contribuir para a articulação entre teoria e prática necessárias à formação dos docentes, elevando a qualidade das ações acadêmicas nos cursos de licenciatura." (BRASIL,2018).

O diretor da Coordenação de Pessoal de Nível Superior (CAPES), Carlos Lenuzza, explica: "o Pibid é muito bem sucedido, mas seu principal problema é ser restrito. Temos numa mesma sala de aula de graduação, alunos que tem acesso ao programa e outros não". (LENUZZA, 2018). Em virtude disso, um novo programa , o Residencia Pedagógica, entrou em vigor, com o objetivo de ampliar o número de vagas disponíveis para formação, pois, "se entendemos que a prática é necessária para a formação de nossos futuros professores, queremos que ela seja para todos." (LENUZZA, 2018). Além disso, Pannuti (2015) tras um outro carater que faz esse programa ser diferencido, segundo ela:

[...] além da carga horária ampliada para a realização das práticas nas instituições de ensino, os alunos também dispõem de um horário quinzenal (duas horas) de supervisão da prática, a qual ocorre em grupo, sob a orientação e a reponsabilidade de um professor supervisor, o que reforça a ideia da importância da dimensão coletiva no processo de formação.

\subsection{PROGRAMA RESIDENCIA PEDAGÓGICA}

O Residência Pedagógica é um programa criado recentemente pela a Coordenação de Aperfeiçoamento Pessoal de Nível Superior - Capes, Fundação Pública no cumprimento das atribuições conferidas pela Lei no 8.405, de 09 de janeiro de1992, e pelo Estatuto aprovado pelo Decreto no 8.977, de 30 de janeiro de 2017, por meio de sua Diretoria de Formação de Professores da Educação Básica (DEB). Com a finalidade, citada no Art. 1ำ da PORTARIA № 38, DE 28 DE FEVEREIRO DE 2018, de apoiar Instituições de Ensino Superior (IES) na implementação de projetos inovadores que estimulem a articulação entre teoria e prática nos cursos de licenciatura, conduzidos em parceria com as redes públicas de educação básica.

O programa prevê bolsas para estudantes de licenciatura na modalidade presencial ou no âmbito do Sistema Universidade Aberta do Brasil (UAB), por Instituições de Ensino Superior (IES) públicas e privadas sem fins lucrativos e destaca no Art. 2ํ da PORTARIA № 38, DE 28 DE FEVEREIRO DE 2018, os objetivos do programa Residência pedagógica:

I. Aperfeiçoar a formação dos discentes dos cursos de licenciatura, por meio do desenvolvimento de projetos que fortaleçam o campo da prática e que conduzam o licenciando a exercitar de forma ativa a relação entre teoria e prática profissional docente, utilizando coleta de dados e diagnóstico sobre o ensino e a aprendizagem escolar, entre outras didáticas e metodologias; II. Induzir a reformulação do estágio supervisionado nos cursos de licenciatura, 
tendo por base a experiência da residência pedagógica; III. Fortalecer, ampliar e consolidar a relação entre a IES e a escola, promovendo sinergia entre a entidade que forma e aquelas que receberão os egressos das licenciaturas, além de estimular o protagonismo das redes de ensino na formação de professores; e IV. Promover a adequação dos currículos e das propostas pedagógicas dos cursos de formação inicial de professores da educação básica às orientações da Base Nacional Comum Curricular (BNCC).

Além desses objetivos podemos citar também que, o RP propõe a antecipação do vínculo entre os futuros docentes e as salas de aula da rede pública. Com essa iniciativa, o programa faz uma conexão entre as licenciaturas da educação superior, a escola e os sistemas estaduais e municipais a favor da melhoria do ensino nas escolas públicas.

0 programa se destaca pelas suas propostas de incentivo de formação de professores, preparados e qualificados para sala de aula. Ele dá ênfase a importância e a necessidade da experiencia entre teoria e prática, dando ao aluno de licenciatura a autonomia de sua formação. Desta forma, o programa dispõe dos discentes dos cursos de licenciaturas além de reformular o estágio supervisionado. Apesar disto, observase que, o programa Residência Pedagógica, baseado nas definições do EDITAL CAPES no $06 / 2018$ e conforme o tópico "Estágio Curricular Supervisionado" do PPC de Licenciatura em Biologia na modalidade presencial, ambas as experiências tem pontos que se aproximam um do outro, já que, um dos objetivos do estágio supervisionado, assim como também da RP, é trazer a relação entre a teoria e prática docente e fazer com que haja a reflexão a respeito do processo de ensino e aprendizagem dentro da sala de aula, como também sobre as relações pedagógico- administrativas no espaço escolar.

\section{RESULTADOS E DISCUSSÃO}

Com a finalidade de orientar a elaboração do cronograma institucional do Projeto Institucional de Residência Pedagógica, é apresentado na tabela 1, uma sugestão de calendário a se seguir por cada instituição que irá implementar o programa.

Tabela 1: sugestão de calendário a ser seguido por cada instituição.

\begin{tabular}{|c|c|c|c|c|c|c|c|c|c|c|c|c|c|c|c|c|c|}
\hline \multicolumn{18}{|c|}{ SUGESTÃO DE CRONOGRAMA } \\
\hline \multicolumn{5}{|c|}{2018} & \multicolumn{11}{|c|}{2019} & 2020 & \multirow{3}{*}{ Total } \\
\hline Ago & Set & Out & Nov & Dez & Jan & Fev & Mar & Abr & Mai & Jun & Jul & Ago & Set & \begin{tabular}{l|l} 
Out & Nov \\
\end{tabular} & Dez & Jan & \\
\hline \multirow{2}{*}{\multicolumn{2}{|c|}{$\begin{array}{l}\text { Preparaçå } \\
\text { do aluno para } \\
\text { participaçå } \\
\text { no programa }\end{array}$}} & \multicolumn{15}{|c|}{ RESIDÊNCIA PEDAGOGICA } & \\
\hline & & \multicolumn{4}{|c|}{60 horas na escola } & \multicolumn{9}{|c|}{320 horas } & 20 horas & 40 horas & \multirow[b]{2}{*}{$\begin{array}{c}440 \\
\text { horas }\end{array}$} \\
\hline \multicolumn{2}{|c|}{$\begin{array}{l}\text { Formaçâa do } \\
\text { supervisor }\end{array}$} & $\begin{array}{l}\text { Orie } \\
\text { (coo } \\
\text { sor) } \\
\text { resic } \\
\text { prep } \\
\text { d }\end{array}$ & $\begin{array}{l}\text { ntaçá } \\
\text { rdenad } \\
\text { ambien } \\
\text { ente n } \\
\text { araça } \\
\text { Ativid } \\
\text { Resid }\end{array}$ & $\begin{array}{l}\text { Don] } \\
\text { dor/su } \\
\text { ttaça } \\
\text { la esc } \\
\text { dade } \\
\text { dade } \\
\text { ência }\end{array}$ & $\begin{array}{r}\text { unta } \\
\text { dervi } \\
\text { do } \\
\text { ola e } \\
\text { lano } \\
\text { la }\end{array}$ & \multicolumn{9}{|c|}{$\begin{array}{l}\text { Imers so na escola contendo o mínimo de } 100 \text { horas de } \\
\text { regência de classe }\end{array}$} & $\begin{array}{l}\text { Relatório } \\
\text { final }\end{array}$ & $\begin{array}{l}\text { Avaliação e } \\
\text { socializaçâo }\end{array}$ & \\
\hline
\end{tabular}

Fonte: EDITAL CAPES no 06/2018.

Nessa tabela podemos notar de inicio que a carga-horario do programa é um pouco maior do que a do estágio supervisionado e está distribuida de modo diferente. No PRP o residente tem que concluir no mínimo 100 hs (cem horas) de regência de classe, diferente do estagio supervisionado, que são 40hs (quarenta horas).

No presente trabalho iremos relatar sobre as 3 (três) primeiras etapas do programa, que são Treinamento, Caracterização e imersão na escola e Regência de classe.

\section{ETAPA 1: TREINAMENTO}

Essa etapa foi realizada logo após a seleção das instituições escolares, dos professores preceptores e licenciandos residêntes que iriam participar do programa. Logo após, foi dado início ao treinamento que podemos definir como uma etapa de formação e preparação de todos os participantes do programa. 
As 60hs de treinamento foram divididas entre os meses de agosto e setembro de 2018 com cursos de formação e preparação de alunos e professores para participação no programa. As aulas do curso eram à distância por vídeo-aulas, mas, com encontros presenciais toda semana com todos os participantes do programa e a coordenação local, com a finalidade de discutir os assuntos abordados na vídeo-aula. Ao todo, foram 12 vídeo-aulas com os seguintes temas: Saberes necessários à docência e o RP do IFRN; A função do residente, Docência e residência e importância do professor para os processos de ensino e de aprendizagem; Relações pedagógicas entre professor (preceptor) e estudantes; Os sentidos e os desafios da educação e da escola; Tipos de planejamento docente e os documentos escolares e a relação teoria, prática e área específica do conhecimento; Desafios e possibilidades da gestão de sala de aula na oferta regular e na educação profissional; Estilos de aprendizagem; Perspectiva de planejamento docente: plano de aula, projetos de trabalho, mapa conceitual e sequência didática; Formação Profissional docente para a educação regular e para a educação profissional; Integração, interdisciplinaridade e multidisciplinaridade; Avaliação de programas e políticas, Aprendizagem, avaliação e desenvolvimento; e por ultimo, Ensino, pesquisa e extensão na formação docente.

Essa etapa foi importante pois as reflexões obtidas com estudos, ocasionaram discussões e tarefas definidas por parte da coordenação, com intuito de refletir sobre a prática docente. Desse modo, esses estudos serviram como suporte teórico, para o desenvolvimento de um pensamento crítico acerca de como o ensino deverá ser desencadeado nas escolas.

\section{ETAPA 2: CARACTERIZAÇÃO E IMERSÃO NA ESCOLA}

Depois de receber todo suporte teórico, durante todo mês de outrubro de 2018 os residêntes foram divididos em três grupo. Cada grupo ficou numa escola-campo diferente, onde deveriam inicialmente realizar a caracterização que permite ao residente um diagnóstico da escola-campo para entender de forma ampliada a sua estrutura e dinâmica de funcionamento. Nesse trabalho iremos relatar apenas as experiências de alunos que ficaram no IFRN/Campus Macau.

Cada aluno portava de um roteiro de caracterização da escola, onde nele continha perguntas para serem feitas a diretoria e a cada setor da escola, além de perguntas a respeito da estutura que deveriam ser respondidas com a observação do local a cada visita realizada pelo residente. Poladian (2014) afirma que "busca-se com a imersão durante o processo de formação inicial, sair do isolamento dos ambientes formativos da universidade e escola, aproximando as culturas destes locais e identificando saídas criativas para a formação docente". Logo, isso nos permitiu o conhecimento da realidade sociocultural dos alunos e também o comportamento fora da sala de aula.

Além da observação geral da escola, cada aluno-residente foi inserido na sala de aula, onde posteriormente seria a classe que realizaria a regência, para a análise das atividades de ensino desenvolvidas pelos professores-preceptores.

No primeiro dia, os residentes foram apresentados as turmas. Nos demais dias de observação, os residentes ficaram na sala, apenas observando. De modo geral, os alunos das classes não demostraram contragimento com a presença dos residentes em sala de aula. Durante os dias de observação foi notório a metodologia utilizada pelo professor, com conteúdos expostos no quadro, porém com um diferencial, o professor fazia desenhos bem elaborados no quadro referentes aos temas abordados em aula, o que chamava bastante a atenção do aluno e tornava a aula mais interativa. No decorrer das aulas pouco utilizou-se outros materiais pedagógicos. Essa etapa nos permitiu conhecer mais de perto os alunos, bem como de seus níveis de aprendizagens.

Próximo ao fim dessa etapa, foram realizadas reuniões com a coordenação, professores preceptores e residentes para análise dos diagnósticos realizados nas escolas, também para elaboração coletiva do planejamento das ações de regência dos residentes para as escolas, permintindo que todos podessem contribuir para a melhoria do plano de ação do residente em atuação.

\section{ETAPA 3: REGÊNCIA DE CLASSE}

Para os residentes que ficaram no IFRN- Campus Macau, essa etapa iniciou-se ao final de Novembro de 2018.2, durante esse periodo alguns dos residentes ficaram em duplas. Mas, no primeiro semestre de 2019, as duplas foram trocadas e a maioria ficou sozinho em uma sala aula. Segundo Ferreira et al. (2019) é nessa fase que colocaremos em prática tudo que foi planejado, discutido e refletido de forma colaborativa e "que pode servir de apoio para entendermos o processo de ensino e aprendizagem decorrente do dia a dia do professor e seus alunos em sala de aula." 
O primeiro momento de regencia de classe foi um desafio muito grande para nós, pois nunca tínhamos lecionado antes e tivemos que lidar com várias situações, que vão desde o planejamento e execução da prática pedagógica até conflitos presentes na sala de aula entre os alunos. Mas, de modo geral, a cada aula buscou-se seguir o planejamento emcima dos planos de aula desenvolvidos para a disciplina visando contemplar os assuntos presentes na ementa. Cada residente possui o seu próprio planejamento pensado para suas respectivas turmas. Logo, a maioria das atividades desenvilvidas em uma turma, não é a mesma desenvolvida para a outra turma.

O professor preceptor acompanha todas as aulas e quando necessário faz intervenções para que o conteúdo não venha ser repassado para os alunos de forma incompleta ou errada. E sempre ao final da aula ele trás um feedback, com a intenção de demostrar os pontos fortes e fracos da aula para que possam vir a aperfeiçoar.

É possível notar a evolução de cada residente em sala de aula, desde o primeiro dia de regência até os dias atuais. Antes o que parecia difícil tem se tornado cada vez mais simples e prazeroso. Cada residente busca desenvolver metodologias que facilite a compressão e a fixação dos conteúdos vistos em sala, por parte dos alunos. Dentre as diversas metodologias que foram desenvolvidas, tanto pelos residentes como pelos seus alunos até o momento, podemos citar: aulas práticas em laboratório e em salas, jogos didáticos, modelos didáticos, modelos esquemáticos e dentre outros. Todos relacionados aos assuntos vistos durante todo o ano.

\section{CONSIDERAÇÕES FINAIS}

Os achados oriundos desta pesquisa possibilitaram identificar que o programa de Residência Pedagógica é uma das ações que integram a política nacional de formação de professores e busca o aperfeiçoamento do estágio curricular supervisionado ao promover a imersão do licenciando nas escolas de educação básica no decorrer de sua formação e não somente ao final do curso. Portanto, observa-se a eficácia que o programa Residência Pedagógica prenuncia para a formação de professores, no qual a relação entre a teoria, prática e fazer docência, permite uma reflexão a respeito do processo de ensino e aprendizagem dentro da sala de aula, como também sobre as relações pedagógico-administrativas no espaço escolar, de modo a preparar o futuro professor a sua atividade profissional.

Com os diversas atividades realizadas neste período de tempo, foi possível percebemos a importância de projetos como o Residência Pedagógica, que de certa forma direciona melhor os alunos da licenciatura para a sala de aula mais preparados, pois, ao está realizando suas práticas conseguem identificar quais características que devem ser aperfeiçoadas ou até mesmo retiradas do seu critério de formação, atingindo uma formação mais dinâmica e completa, não somente baseadas em teorias, mas também nas práticas.

\section{REFERÊNCIAS}

[1] Brasil, Edital capes no 06/2018. Programa de residência pedagógica. p.20.

[2] Brasil-Capes.Portaria no38,de28 defevereiro de2018.Disponível:<http://www.capes.gov.br/educacaobasica/programa-residencia-pedagogica>. Acesso em outubro/2018.

[3] Brasil-Capes. Edital no 61/2013 - capes/deb- adaptação - portaria no 46, 11 de abril de 2016.

[4] Brasil. Edital Pibid № 01/2018, de 08 de junho de 2018. 2018. Disponível

em:<https://www.ifpb.edu.br/pre/editais/pibid-programa-institucional-de-bolsa-de-iniciacao-a- docencia/editais2018/edital-pibid-no-01-2018_processo-seletivo-de-discentes-para-iniciacao- a-docencia.pdf/view>. Acesso em: 28 de set. 2019.

[5] Lennuza, Carlos. Residência pedagógica quer universalizar a iniciação à docência. São Paulo, 27 Dez. 2017. Seminário Residência Pedagógica

[6] Ferreira, J. M. A. Et al., O estudo de aula como mecanismo didático em Residência Pedagógica. XV CIAEMIACME, Medellín, Colombia, 2019.

[7] Souza, Dulcinéia Beirigo de. Os Dilemas do Professor Iniciante: Reflexões sobre OS Cursos de Formação Inicial. Revista Multidisciplinar da Uniesp, 2009. Disponível em: $<$ http://www.espacomarciocosta.com/pdf/ingles/questoes-teoricas-e-metodologicas/os- dilemas-do-professoriniciante-souza-2009.pdf>. acesso em 23 de setembro de 2019.

[8] Gatti, Bernardete A. Formação de professores: condições e problemas atuais. Revista internacional de 
formação de professores, v. 1, n. 2, p. 161-171, 2016.

[9] Pannuti, Maísa Pereira. A Relação Teoria e Prática na Residência Pedagógica. V Seminário Internacional Sobre Profissionalização Docente- Sipd/Catedral Unesco (2015). Disponível em: https://educere.bruc.com.br/arquivo/pdf2015/15994_8118.pdf. Acesso em 20 de setembro de 2019.

[10] Pereira, Júlio E. Diniz. Formação de professores, trabalho docente e suas repercussões na escola e na sala de aula. Educação \& Linguagem, São Paulo: Universidade Metodista de São Paulo, ano 10, n. 15, p. 82-98, jan./jun. 2007.

[11] Poladian, Marina Lopes Pedrosa et al. Estudo sobre o Programa de Residência Pedagógica da Unifesp: Uma aproximação entre universidade e escola na formação de professores. 2014. 


\section{Capítulo 8}

Limites do atendimento educacional especializado na Escola Pública e as contribuições do PIBID em sala de aula

\section{Fernanda Letícia Sousa Lima}

Alane Delmondes Nóbrega

Tânia Serra Azul Machado Bezerra

Resumo: Este trabalho discorre sobre os limites do Atendimento Educacional Especializado (AEE), tomando como referência as experiências proporcionadas durante um ano de inserção no Programa Institucional de Bolsas de Iniciação à DocênciaPIBID/CAPES, na Escola Municipal Professor Francisco de Melo Jaborandi, localizada no bairro Jangurussu em Fortaleza. Trata-se, metodologicamente, de um relato de experiência, utilizando nossos diários de campo como norteadores, bem como realizamos cruzamento de fontes a partir de estudo bibliográfico. Durante a discussão do trabalho pontuamos sobre o caso específico de uma aluna, descrevendo seu histórico de inserção escolar, explanando a maneira que atuamos de modo direto para com ela e realizando reflexões sobre a falta de profissionais especializados para lidar com crianças que necessitam de abordagem pedagógica diferenciada devido suas especificidades educacionais.

Palavras-chave: AEE, PIBID, Escola, Especificidades educacionais. 


\section{INTRODUÇÃO}

Há um ano inseridas no contexto da Escola Professor Francisco de Melo Jaborandi, localizada no Jangurussu, através do Programa Institucional de Iniciação à Docência - PIBID/CAPES, conseguimos refletir e analisar sobre algumas das especificidades de caráter organizacional que perpassam a escola, especialmente em sala de aula, e que afetam as condições de atuação dos profissionais da educação, assim como problematizamos sobre o rumo dos processos de desenvolvimento de algumas crianças, visto que, o presente quadro na qual a escola pública encontra-se, inviabiliza o preenchimento das possíveis necessidades educacionais que emergem.

Um fenômeno específico o qual percebemos que dificulta bastante o desenvolvimento do professor em sala de aula é o déficit de profissionais qualificados para o acompanhamento daqueles alunos com alguma necessidade educacional diferenciada. Na sala de aula em que contribuímos e acompanhamos o processo de ensino-aprendizagem das crianças, é notória a urgência de um apoio, a fim de complementar a ação pedagógica do professor. Apesar de a quantidade de alunos em sala ser a recomendada pela Comissão de Educação e Cultura, é nítido a deficiência no amparo necessário a cada um, ainda mais daqueles que demandam maior sensibilidade durante os processos de mediação dos conteúdos.

Nesse sentido, nós, bolsistas do PIBID/CAPES, orientadas pela professora regente, desde o início do ano letivo, acompanhamos com maior proximidade uma aluna do $1^{\text {o }}$ ano do Ensino Fundamental I, que apresenta muitas dificuldades de aprendizagem e de sociabilidade, suscitando a necessidade de um acompanhamento especializado. Assim, ao longo desse período, desenvolvemos algumas atividades e estratégias pedagógicas com o intuito de contribuir com o aprendizado dessa criança, contudo, apesar dos estímulos, a criança não tem respondido de forma satisfatória no que diz respeito a apreensão dos conteúdos básicos.

A inclusão, conceito socialmente construído e revolucionário, não diz respeito somente ao acesso de pessoas discriminadas às salas de aulas, mas prevê implementação de mecanismos que favoreçam situações de equidade, permitindo-lhes o acesso a todos os segmentos sociais (SANTOS, 2015, p. 21)

Ademais, em relação à interação da mesma com as outras crianças, com a professora e conosco, percebemos avanços e maior receptividade. Presumimos que, apesar de nossa contribuição ao longo deste processo e das práticas inclusivas por parte da educadora, a criança pode ser prejudicada de alguma forma, pois não possui a devida assistência especializada que precisa.

\section{METODOLOGIA}

Trata-se de um relato de experiência de natureza qualitativa a partir das nossas vivências como bolsistas do Programa Institucional de Bolsas de Iniciação à Docência - PIBID/CAPES, em turmas de 1o ano do ensino fundamental, na Escola Municipal Professor Francisco de Melo Jaborandi, localizada no bairro Jangurussu, em Fortaleza - Ceará.

Segundo Severino (2007), a pesquisa científica exige técnicas e a aplicação de uma sequência metodológica, mas Minayo (2001) traz uma contribuição pertinente quando indica que a atividade de pesquisa não deve ser restrita tão e somente ao uso de técnicas refinadas para obtenção de dados.

A pesquisa qualitativa responde a questões muito particulares. Ela se preocupa [...] com um nível de realidade que não pode ser quantificado. Ou seja, ela trabalha com o universo de significados, motivos, aspirações, crenças, valores e atitudes, o que corresponde a um espaço mais profundo das relações, dos processos e dos fenômenos que não podem ser reduzidos à operacionalização de variáveis. (Minayo, 2001, p.21)

Podemos então compreender nossa pesquisa como qualitativa, a partir de um estudo de caso, pois trazemos como centro do estudo um caso em particular. Trata-se, também, de uma pesquisa ação, visto que por meio da nossa inserção na escola através do PIBID, buscamos trazer modificações pertinentes àquela realidade. Com essa pesquisa objetivamos explicar, registrar e fazer análises, utilizando a observação como técnica para estruturar a pesquisa.

Para nortear essa pesquisa, utilizamos os apontamentos dos nossos diários de campo, em que registramos a rotina escolar, o desenrolar das atividades desenvolvidas em sala e o progresso dos alunos. Estes registros são de suma importância para o nosso processo formativo, pois através deles, refletimos e 
analisamos os acontecimentos e, a partir de então, poderemos estudar uma maneira de contribuir com o fazer docente da professora regente, a fim de, colaborar com o desenvolvimento cognitivo das crianças.

Ao planejar, é importante ter o olhar voltado para as reais necessidades do aluno, rompendo de vez com a visão de alunos iguais, pois, até o mesmo tipo de deficiência pode gerar processos inteiramente diferentes de desenvolvimento do aluno, a partir de contextos sociais distintos (MRECH, 2001, p.06 apud SOUZA; COSTA; HOLANDA, 2015, p.254 ).

Nesse sentido, apresentamos as nossas estratégias metodológicas, bem como os resultados ao decorrer dessas atividades, com uma aluna em especial, que possui certa dificuldade motora e no tocante à apreensão dos conteúdos. Construímos alguns materiais pedagógicos, como um quebra cabeça de pregadores com o nome da mesma, contendo, a cada letra, uma cor, pois a escola carece de recursos especializados que possam estimulá-la.

Deste modo, buscamos fazer reflexões sobre a relação da falta de profissionais para o Atendimento Educacional Especializado e a demanda de alunos, e a influência desses fatores durante o processo de ensino-aprendizagem, da aquisição da língua escrita e da assimilação de conteúdos básicos.

\section{DESENVOLVIMENTO}

A criança que assistimos em sala de aula tem 6 anos, está no 10 ano de Ensino Fundamental I e possui dificuldades evidentes durante o seu processo de construção da língua escrita, em sua comunicação e interação com os outros alunos. As observações são voltadas, de maneira mais específica, para a área do letramento, alfabetização, aquisição da escrita e conhecimentos primários, já que estes são trabalhados de maneira mais contundente neste período de ensino.

Para Magda Soares (2005), há uma diferenciação entre os conceitos de alfabetização e letramento, para a autora, alfabetização

designa o ensino e o aprendizado de uma tecnologia de representação da linguagem humana, a escrita alfabético-ortográfica. 0 domínio dessa tecnologia envolve um conjunto de conhecimentos e procedimentos relacionados tanto ao funcionamento desse sistema de representação quanto às capacidades motoras e cognitivas para manipular os instrumentos e equipamentos de escrita (SOARES, 2005, p. 24)

ou seja, as crianças adquirem as informações e a executam de modo que não associa com a sua prática cotidiana. Já o letramento diz respeito ao "conjunto de conhecimentos, atitudes e

capacidades envolvidos no uso da língua em práticas sociais e necessários para uma participação ativa e competente na cultura escrita" (SOARES, 2005, p. 50).

Durante esse processo a criança elabora hipóteses, a hipótese inicial diz respeito a diferenciação entre letras e desenhos, "a linha divisória fundamental que a criança procura estabelecer é a que separa o desenho representativo da escrita" (FERREIRO, 1999, p. 51). A criança no início da nossa observação, ainda não fazia a diferenciação de letras e desenhos, atualmente, de modo mais simplificado a criança reconhece apenas duas letras do seu nome, o "k" e o "a", por muitas vezes, diz ter esquecido que letras são essas. 0 que nos faz pensar, juntamente com a análise da professora, que a aluna não conserva informações relacionadas ao código linguístico, e para além disso, conhecimentos básicos, como as cores.

O histórico dessa aluna é permeado por lacunas advindas da falta de acompanhamento familiar, de suas ausências contínuas às aulas e, também, da falta do adequado auxílio escolar especializado. De acordo com a sondagem que fizemos com o corpo docente da instituição, a aluna começou a ter frequência na escola apenas no final do ano de 2018, que corresponde ao final do ciclo da Educação Infantil. Ou seja, a mesma, foi duramente prejudicada, pois seria nesse período, através das mediações, das interações e das brincadeiras que essa criança iria construir a sua identidade, produzir a sua cultura infantil, vivenciar diferentes situações e, assim, constituir-se como indivíduo histórico e ativo dentro da sociedade.

Compreendemos a Educação Infantil como o início do processo de letramento da criança, é neste espaço onde a criança começa a ter mais acesso a língua escrita e suas funcionalidades, como nas contações de história, tomando nota disto, é necessário evidenciar 
"a importância do papel da escola na inserção das crianças na cultura escrita desde cedo" (BRANDÃO, 2018, p. 20). Porém esta inserção deve se dissociar de uma perspectiva escolarizante, propiciando a criança circunstâncias diversas a partir das brincadeiras e interações.

Ao adentrarmos no contexto da sala de aula, a professora foi extremamente solícita e nos passou um breve histórico de cada criança, explicando que a aluna estava com bastante dificuldade e que isto levantava preocupação em relação ao seu processo de aprendizagem. A partir das observações e do acompanhamento nessa turma, percebemos que todos os alunos estavam em um certo nível de aquisição da leitura e da escrita e, com o passar do tempo, eles continuavam ascendendo nesse processo e esta aluna permanecia aquém. Eles também interagiam comumente entre si e com as mediadoras em sala.

A dificuldade de interação, socialização e comunicação entre a aluna e os colegas e aluna e a professora, também era algo notório. Sabemos que com as práticas desenvolvidas na Educação Infantil, como as rodas de conversa, onde as crianças podem interagir, conversar, contar vivências do seu cotidiano, são facilitadores no processo de comunicação da criança, e proporciona ainda, a ampliação de "suas habilidades de uso da linguagem. Aprendem a estruturar textos oralmente, a variar modos de falar, a interagir de modo cada vez mais autônomo" (BRANDÃO, 2018, p. 21), e estas características não eram perceptíveis na criança.

Com isso, fomos direcionadas pela professora regente a fazermos intervenções específicas com essa aluna, para contribuir com o seu processo de construção dos conhecimentos. Posteriormente, voltamos às atividades dirigidas especialmente para a ambientação e escrita do sistema alfabético. A atividade de recorte com as mãos fez com que a aluna desenvolvesse a sua habilidade de manipulação de objetos através do movimento de pinça, como o manuseio do lápis. Foi então que começamos com a caligrafia do nome dela, pois habituar as crianças a escreverem os seus nomes com o auxílio de uma ficha contendo, em letra bastão, o seu nome completo, é uma atividade costumeira da Educação Infantil.

Sabemos que "é crescente o espaço que as fichas vem ocupando na rotina das instituições que atendem crianças menores de seis anos" (BRANDÃO; CARVALHO, 2018, p. 140), porém as utilizamos como um meio de auxiliar na construção da aquisição da língua. Pontuamos que, essas atividades, ainda na Educação Infantil, precisam ser trabalhadas de forma lúdica, Brandão e Carvalho (2018) destacam que as fichas devem ampliar suas oportunidades de refletir e elaborar suas hipóteses, é dessa maneira que buscamos trabalhar, sempre utilizando como base os conhecimentos prévios da criança.

Durante o curso de atividades com esse mesmo caráter, mesmo com o auxílio das tarjas, a criança apresentou muita dificuldade em representar as letras. Faz-se necessário destacar que, a professora responsável possui formação em Psicopedagogia, devido a isso, possui uma maior sensibilidade em reconhecer transtornos cognitivos. Também, possui maior desenvoltura para intervir através de dinâmicas pedagógicas inclusivas, contudo, a sua responsabilidade não é a de encarregar-se integralmente às demandas dos discentes com necessidades educacionais especiais, já que a instituição tem por obrigação oferecer o suporte necessário.

o profissional de AEE deve pesquisar, decidir, organizar, criar, desenvolver recursos além dos já disponíveis na sala multifuncional, procurando suprir as necessidades do aluno atendido, de maneira criativa e inovadora, o que não significa dispensar o planejamento que é elemento norteador do processo ensino-aprendizagem. (SOUZA, 2015, p.252).

Além disso, fizemos atividades voltadas para o estímulo do reconhecimento das cores. Em uma das situações, a criança deveria associar a cor que estava pintada na folha de papel à cor do giz de cera. Através da atividade concluímos que ela não possui nenhum problema visual aparente em relação à percepção das cores. Entretanto, mesmo após diversas atividades que fomentassem a identificação das cores, a criança ainda não conserva a maiorias delas. 0 que nos motiva, ainda mais, a crer que a criança necessite de acompanhamento pelo Atendimento Educacional Especializado (AEE). A professora regente já notificou a coordenação pedagógica da escola e solicitou uma avaliação da criança pela psicopedagoga, mas devido a grande quantidade de alunos que demandam desta assistência e a disponibilidade de apenas uma profissional para tal, esta avaliação ainda não pôde ser feita.

\section{RESULTADOS E DISCUSSÃO}

Nossa escola de atuação funciona em dois turnos, com turmas da Educação Infantil e do Ensino Fundamental I, deste modo, percebemos que a quantidade de alunos não é adequada para apenas uma 
profissional capacitada para o AEE. As turmas do primeiro ano da tarde ainda não foram direcionadas para fazer a avaliação, pois a preferência é dada aos alunos do $2^{\circ}$ e $4^{\circ}$ ano, supomos que seja porque, esses níveis, sofram maior pressão das avaliações externas. Notamos que a falta do atendimento especializado restringe o desenvolvimento das potencialidades das crianças com necessidades educacionais especiais e, portanto, as mesmas estão sendo negligenciadas pelo sistema de ensino, que carece de profissionais e não providencia a alocação de outros para o atendimento no AEE.

0 atendimento especializado deve estar disponível em todos os níveis de ensino, de preferência na rede regular, desde a educação infantil até a universidade. A escola comum é o ambiente mais adequado para garantir o relacionamento entre os alunos com ou sem deficiência e de mesma idade cronológica, bem como a quebra de qualquer ação discriminatória e todo tipo de interação que possa beneficiar o desenvolvimento cognitivo, social, motor e afetivo dos alunos em geral. (MANTOAN, 2006, p. 27)

O marco nas políticas educacionais que levou em consideração a Educação Especial foi a Lei no 9.394, de 20 de dezembro de 1996, que estabelece as diretrizes e bases da educação nacional e traz um capítulo, apesar de básico e introdutório, com regulamentações para esse tipo específico de educação. No artigo 59 traz a garantia de que os sistemas de ensino devem assegurar aos educandos com deficiência, transtornos globais do desenvolvimento e altas habilidades ou superdotação, currículos, métodos, técnicas, recursos educativos e organização específicos, para atender às suas necessidades, além de professores com especialização adequada para a integração dos educando em salas de aulas comuns.

Segundo o artigo 2º da resolução no 4, de 2 de outubro de 2009, que institui Diretrizes Operacionais para o Atendimento Educacional Especializado na Educação Básica, modalidade Educação Especial, o atendimento educacional especializado tem duas funções: complementar e suplementar. Essa deve ocorrer por meio da disponibilização de serviços, recursos de acessibilidade e estratégias, a fim de eliminar as barreiras para sua plena participação na sociedade e desenvolvimento de sua aprendizagem.

Trazendo para o âmbito municipal, há a resolução № 10/2013 do Conselho Municipal de Educação de Fortaleza, no seu artigo 13, traz que alunos que não possuem laudo, devem ser encaminhados ao atendimento educacional especializado na sala de recursos multifuncionais, deve ter na escola, mediante avaliações e relatórios do professor de sala regular e do professor especializado para este serviço que justifique os motivos deste encaminhamento.

A partir de todos essas determinações da legislação educacional especial brasileira, podemos ver e compreender que há de maneira clara o descumprimento destas. A aluna em questão já foi avaliada de maneira inicial pela professora regente e a mesma solicitou à coordenação o encaminhamento da aluna ao AEE, mas até o momento, não houve intervenção alguma nesse sentido.

Segundo Vygotsky (1989, p.03 apud VALDÉS, 2003) a criança com alguma necessidade especial se desenvolve de maneira diferente, e com isso, devemos estimular o desenvolvimento de suas potencialidades. No contexto escolar, o docente não consegue fazer isso de maneira específica, devido à quantidade de responsabilidades e demandas da sala de aula. É nesse momento que faz-se necessário o AEE, pois para auxílio dessas crianças, é imprescindível que o educador seja especializado e que os materiais sejam adequados.

Além do mais, acreditamos que, ainda que haja a necessidade de mais profissionais, é imprescindível, também, a articulação do professor regente com o profissional do AEE, para que, de maneira conjunta, indissociável, e articulada, um contribua com o outro para a construção do conhecimento do aluno, assim, assegurando a qualidade e efetividade do atendimento, buscando sempre contribuir para a autonomia do educando, pois, segundo Freire (2007, p. 59), o respeito à autonomia e à dignidade de cada um é um imperativo ético e não um favor que podemos ou não conceder uns aos outros.

O AEE tem como propósito a eliminação de barreiras que dificultam o acesso ao conhecimento e impedem a plena participação de alunos com deficiências, transtornos globais de desenvolvimento e altas habilidades/ superdotação com vistas a contribuir para que possam transitar pela escola e fora dela com maior autonomia". (SOUZA; COSTA; HOLANDA, 2015, p. 259).

A ideia de total dependência que vinculam ás crianças que apresentam alguma dificuldade ou necessidade educacional especial é algo perpetuado, vemos professores que contribuem para a manutenção desta concepção, deste modo, os profissionais do AEE podem e devem trabalhar para a quebra desse paradigma, possibilitando que a criança seja o centro do seu processo educativo. 
O aprendiz é um sujeito protagonista no seu próprio processo de aprendizagem, alguém que vai produzir a transformação que converte em informação em conhecimento próprio. Essa construção pelo aprendiz não se dá por si mesma e no vazio, mas a partir de situações nas quais ele possa agir sobre o objeto de seu conhecimento, pensar sobre ele recebendo ajuda, sendo desafiado a refletir (WEISZ, 2004, p. 60).

Neste sentido, o AEE atua como um importante mecanismo de promoção do desenvolvimento autônomo das crianças com necessidades educacionais especiais para que elas se tornem ativas e tenham as mesmas condições de participação nos processos de construções sociais, não só dentro de sala de aula, mas nas diversas esferas da sociedade.

\section{CONSIDERAÇõES FINAIS}

Durante nossas aproximações com a criança, buscamos desenvolver sua interação, atualmente, notamos seu maior desenvolvimento nas questões sociais, consegue interagir com os colegas, conosco e com as professoras. Consegue manter um diálogo e se mostra desenvolta quando pedimos que desempenhe alguma atividade que necessite de comunicação direta.

Consideramos que a insuficiência do Atendimento Educacional Especializado - AEE na escola em pauta, está, ao mesmo tempo que excluindo, negligenciando a aluna acompanhada, pois a mesma está sendo impedida de gozar de seus direitos plenos, no tocante às possibilidades educacionais para desenvolver-se explorando suas potencialidades. Segundo Lima (2015), a prevenção de danos, estimulação adequada, ambiente favorável ao aprendizado são fatores que podem fazer parte da prática do educador que vislumbra uma efetiva inclusão social.

Mesmo sabendo que o ideal seria que a criança recebesse o apoio do AEE, percebemos que a nossa intervenção em sala de aula contribuiu para uma melhor dinâmica, consequentemente, uma melhor aproximação do processo de ensino-aprendizagem da aluna. Apesar de nossas contribuições, não percebemos um salto no seu processo, na verdade, com as vivências e observações, conseguimos notar que em dados momentos, quando interpretamos seu avanços como internalizados, ela apresenta o processo contrário. Para exemplificar, podemos citar um dia em sala de aula que ela comentou de maneira espontânea e natural determinada cor relacionando com seu nome correto, posteriormente, a questionamos e ela já não conseguia sequer lembrar.

No mais, destacamos a importância do aprofundamento e apropriação, por parte dos docentes, nas ciências Educação e Psicologia para que possamos compreender de que forma estas correlacionam-se e, então, podermos contribuir de forma significativa para os processos de aprendizagem das crianças.

\section{REFERÊNCIAS}

[1] Brasil. Lei de Diretrizes e Bases da Educação Nacional. Lei no 9.394, 20 de dezembro de 1996.

[2] _._. Resolução no. 4, de 2 de outubro de 2009. Diretrizes Operacionais para o Atendimento Educacional Especializado na Educação Básica, modalidade Educação Especial, Brasília: MEC, 2009.

[3] Brandão, A.C.P; Carvalho, M.J.P. As fichas de atividades de língua escrita na Educação Infantil. In: Brandão, A.C.P; Rosa, E.C.S (Orgs). Ler e escrever na Educação Infantil: discutindo práticas pedagógicas. 2. ed.; 4. reimp. Belo Horizonte: Autêntica, 2018.

[4] Brandão, A.C.P; Leal, T.F. Alfabetizar e letrar na Educação Infantil: o que isso significa? In: Brandão, A.C.P; Rosa, E.C.S (Orgs). Ler e escrever na Educação Infantil: discutindo práticas pedagógicas. 2. ed.; 4. reimp. Belo Horizonte: Autêntica, 2018.

[5] Brandão, A.C.P; Rosa, E.C.S (Orgs). Ler e escrever na Educação Infantil: discutindo práticas pedagógicas. 2. ed.; 4. reimp. Belo Horizonte: Autêntica, 2018.

[6] Ferreiro, Emília; Teberosky, Ana. Psicogênese da Língua Escrita. Trad. Diana Myriam Lichtenstein, Liana Di Marco, Mário Corso. Porto Alegre: Artmed, 1999.

[7] Freire, Paulo. Pedagogia da Autonomia: saberes necessários à prática educativa. 35 ed. São Paulo: Paz e Terra, 2007.

[8] Fortaleza. Conselho Municipal de Educação de Fortaleza - CE. Resolução № 010/2013. Fortaleza: CME, 2013. 
[9] Magalhães, Rita de Cássia Barbosa Paiva. (org). Reflexões sobre a diferença: uma introdução à educação especial. Fortaleza, Edições Demócrito Rocha, 2003.

[10] Mantoan, Maria Teresa Eglér. Inclusão escolar: O que é? Por quê? Como fazer? 2. ed. São Paulo: Moderna, 2006.

[11] Minayo, Maria Cecília de Souza (org.). Pesquisa Social: Teoria, método e criatividade. 18 ed. Petrópolis: Vozes, 2001.

[12] Santos, Geandra Claudia Silva; Ribeiro, Renata Rosa Russo Pinheiro Costa; Sampaio, Rosa Maria Goes; Pinto, Soraya Eli Lira (Orgs). Inclusão: saberes, reflexões e possibilidades de uma prática em construção. Fortaleza, Eduece, 2015.

[13] Severino, Antônio Joaquim. Metodologia do trabalho científico. 23 ed. São Paulo: Cortez, 2007.

[14] Soares, Magda. Alfabetização e letramento. Belo Horizonte: Ceale/FaE/UFMG, 2005.

[15] Valdes, M. T. A educação especial na perspectiva de Vygotsky. In: Magalhães, R.C.B.P (org). Reflexões sobre a diferença: uma introdução à educação especial. Fortaleza, Edições Demócrito Rocha, 2003.

[16] Weisz, T. o diálogo entre o ensino e a aprendizagem. 2. ed. são Paulo: Ática, 2004. 


\section{Capítulo 9}

O Programa de Capacitação Docente do Instituto Chapada de Educação e Pesquisa (ICEP) e suas implicações na formação leitora dos alunos do sexto ano no Município Baiano de Xique-Xique

\section{Jaklane Nunes Rabêlo}

Resumo: 0 presente trabalho científico apresenta os resultados de uma pesquisa exploratória ${ }^{14}$ que utilizou diferentes técnicas e procedimentos (a revisão bibliográfica, a aplicação de questionários abertos, a análise de dados qualitativo e quantitativo etc.) para investigar o processo de implantação e funcionamento do Programa de capacitação docente do Instituto Chapada de Educação e Pesquisa (ICEP), no município baiano de Xique-Xique. Nessa investigação, procurava-se observar se essa política público-privada - implantada pelo governo municipal, em parceria com uma instituição privada (ICEP) teria ou não conseguido conscientizar os professores de Língua Portuguesa da rede pública municipal, sobre a necessidade de inovar a prática de ensino para conseguir intervir positivamente no processo de formação leitora dos alunos do sextos anos do Ensino Fundamental. Como resultado, a pesquisa mostrou que, embora tivesse existido alguns entraves que dificultaram o pleno êxito dessa proposta política-educativa, o Programa investigado, ainda assim, pode alcançar seu objetivo final, garantindo, com isso, um melhoramento na qualidade educativa no município pesquisado.

Palavras-chave: Políticas públicas, Formação docente, Ensino-aprendizagem, Formação leitora. 


\section{INTRODUÇÃO}

A leitura e a escrita são a base para se construir e disseminar conhecimentos e saberes. Desse modo, investir em alfabetização e formação leitora de crianças e jovens deveria ser prioridade dentro das propostas políticas e educativas de todos os governos (federal, estadual e municipal). No Brasil, apesar dos avanços educativos conquistados, percebe-se, no entanto, que as políticas públicas educativas, voltadas a alfabetização e formação de leitores, ainda não têm efetivamente recebido a atenção que merece. Talvez, por isso, inúmeros indicadores - que medem o desempenho educativo de estudantes em diferentes regiões do país - tenham mostrado que, dentre outros problemas educativos, o sistema público de ensino, ainda precisa enfrentar e superar questões como a baixa qualidade da alfabetização e a má formação leitora.

Essa constatação tem causado bastante preocupação, pois a baixa qualidade desses processos educativos tem gerado sérios prejuízos para o desenvolvimento intelectual e profissional da população bem como para o desenvolvimento do país que perde a chance de possuir uma geração de intelectuais e profissionais capacitados que saibam aproveitar o poder da leitura e da escrita como meio para adquirirem/construírem conhecimentos que serão necessários no processo de transformação da sua vida pessoal e social. Em vista disso, autoridades governamentais e sociedade têm se mobilizado para, juntos, desenvolverem iniciativas político-educativas no sentido de garantir o melhoramento do processo de alfabetização e, conseguintemente, da formação leitora dos estudantes brasileiros, focalizando na importância do papel do professor como uma das estratégias para solucionar essa problemática socioeducativa.

Nessa proposta, o trabalho docente passa a ser considerado como ponto chave dentro do processo de melhoramento da educação. Por isso, tornou-se tão necessário ampliar os investimentos na formação e capacitação continuada dos professores, no sentido de aprimorar seus conhecimentos, preparando-os para lidarem melhor com a complexidade do processo de ensino-aprendizagem, especialmente, o da leitura e da escrita que dão sustentação a outros tipos de conhecimentos dentro do processo de escolarização.

Assim, tentando compreender melhor essa proposta político-educativa que prioriza a formação docente como instrumento para melhorar a formação leitora de estudantes, a referida pesquisa propôs conhecer, analisar e refletir sobre o processo de implantação e funcionamento do Programa de capacitação docente do Instituto Chapada de Educação e Pesquisa (ICEP) no contexto educativo do município de Xique-Xique, Bahia/Brasil, observando suas implicações no processo de formação leitora dos alunos do sexto ano do ensino fundamental. A pesquisa tinha como objetivo principal identificar se essas políticas educativas (público-privada) teria ou não conseguido contribuir no processo de conscientização dos docentes de Língua Portuguesa (grupo pesquisado), a ponto de fazê-los transformar suas práticas pedagógicas e, com isso, melhorarem o processo de formação leitora dos seus alunos, elevando a qualidade educativa dentro do município pesquisado.

\section{METODOLOGIA}

0 presente estudo é o resultado de uma pesquisa de campo exploratória (Preste, 2010) que, seguindo o método dedutivo (Lakato e Marconi, 2006), procurou utilizar, no processo investigativo, diferentes instrumentos e técnicas, no intuito de abarcar uma maior quantidade de informações que ajudassem a aprofundar os conhecimentos sobre os fatos e a realidade a ser pesquisada. Para isso, a referida pesquisa foi constituindo-se a partir dos seguintes procedimentos metodológicos: a observação do espaço e do processo formativo; a seleção dos agentes respondentes; a visitas in loco (as instituições de ensino em que lecionavam os docentes pesquisados); o estudo bibliográfico; a aplicação de questionários abertos; a análise de dados quantitativos e qualitativos.

A observação sistemática ocorreu durante todo o processo formativo (cerca de quatro meses), sendo de fundamental importância para confirmar algumas hipóteses e definir qual seria o grupo de professores que responderiam os questionários abertos - foram selecionadas três professoras que lecionavam em turmas de sextos anos, nos três ${ }^{15}$ maiores colégios municipais. Após a observação, optou-se em realizar as

\footnotetext{
15 Devido a números reduzidos de professores que concluíram o curso de formação/capacitação, não houve a possibilidade de aumentar a quantidade de respondentes. Por isso, optou-se em selecionar o grupo com uma quantidade maior de participantes (o grupo que lecionava no sexto ano). Além disso, nessa seleção, também,
} 
visitas in loco, para conhecer de perto o espaço escolar em que cada uma das respondentes estava inserida e confrontar as informações coletadas com a realidade ali observada. Logo depois, analisou-se dados quantitativos que estavam disponíveis em meio digital (QEDU, 2015), que ajudaram a entender quais eram os desafios a ser enfrentados pelos professores em relação a aprendizagem da leitura e da escrita e a formação leitora dentro do município pesquisado. Por fim, analisou-se os dados qualitativos que mostraram as impressões e expectativas dos docentes diante da proposta do Programa ICEP e dos resultados alcançados em sala de aula, referente ao processo de formação leitora.

\section{DESENVOLVIMENTO}

O Programa de formação docente investigado faz parte de um projeto desenvolvido pelo Instituto Chapada de Educação e Pesquisa (ICEP). Esse projeto é uma iniciativa do setor privado que, em parceria com os governos municipais, tem promovido a formação/capacitação continuada de agentes educativos em diversos municípios da região da Chapada Diamantina e em outras da Bahia. O Projeto do ICEP procura desenvolver estratégias de mobilização sociopolítica, articulando setores políticos, privados e da sociedade civil em prol do desenvolvimento da educação pública de qualidade. Tal instituto, além de desenvolver projetos ligados à formação continuada de professores e gestores educacionais, também é responsável pela criação de redes colaborativas que envolvem educadores, secretarias municipais da educação e a comunidade no processo de fortalecimento do ensino formal e das políticas públicas na região (ICEP, 2017).

Em Xique-Xique - cidade baiana, localizada às margens do rio São Francisco - a proposta de formação docente do ICEP foi implantada pelo governo municipal como uma política-educativa que, com foco na formação do professor, visava o melhoramento do processo de ensino-aprendizagem e, consequentemente, da qualidade da educação.

A proposta do ICEP foi implantada, porque, os Índices de Desenvolvimento da Educação (IDEB) do município estavam abaixo do esperado. No ano 2015, por exemplo, os resultados mostraram que o desempenho de aprendizagem dos estudantes das escolas públicas municipais em Língua Portuguesa e Matemática estavam abaixo da média estabelecida para o estado e para o país (QEDU, 2015). Em relação a área de Língua Portuguesa (foco da pesquisa), esses resultados revelaram, ainda, que, enquanto no âmbito federal, a competência leitora dos alunos das escolas públicas crescia 9\% (comparando a anos anteriores); no município de Xique-Xique, esse percentual permanecia o mesmo: apenas, 5\%.

Diferença essa que indicava que o ensino público ofertado no município precisava urgentemente de atenção, especialmente, nas etapas dos anos finais do Ensino Fundamental, em que se havia notado que os estudantes, a cada ano, apresentam níveis de desempenho educativo ainda mais baixos do que os apresentados pelos estudantes dos anos iniciais. E, frente a isso, a iniciativa do governo municipal, em parceria com o ICEP, emergia como uma tentativa de enfrentar e solucionar essa problemática educativa que estaria inviabilizando o processo de melhoramento da qualidade de ensino na rede municipal.

Assim, procurando compreender melhor esse universo das políticas públicas que buscam transforma docente em formadores de leitores, iniciou-se uma investigação sobre a influência do programa de formação docente do ICEP no processo de melhoramento da formação leitora dos alunos dos sextos anos, que pode contribuir na construção do presente trabalho cientifico.

Dividido em três capítulos, esse trabalho científico procurou, inicialmente, refletir e discutir, no primeiro capítulo, sobre o poder social da leitura e da escrita, ressaltando a importância de tais processos na construção da história política, social e cultural da humanidade. Assim, tomando como base o pensamento de Alqueres (2008) entendeu-se que,

A linguagem escrita é uma das maiores invenções de todos os tempos, um instrumento que evoluiu para atender ao inexorável avanço da humanidade. Tamanha sua importância que se tornou uma ferramenta de poder: aqueles que detinham o domínio do conhecimento, em geral adquirido pela escrita e pela leitura, passaram a sobre pôr-se a aqueles que não a possuíam (Alqueres, 2008, p. 15).

considerou-se a questão desse grupo ter revelado que é nessa série que ocorre os maiores problemas com a questão da alfabetização e da formação de leitores. 
Nesse capítulo mostrou-se ainda - com base em reflexões de autores como Chartier (1994), Paulo Freire (1993), Perroti (1999), Soares, (2002) entre outros - o quanto foi importante modificar as concepções e os conceitos sobre o termo leitura e leitor, para modificar, ao longo do processo histórico, as práticas de ensino-aprendizagem voltadas à alfabetização e ao letramento e, consequentemente, à formação de leitores dentro e fora do contexto escolar.

No segundo capítulo, discutiu-se - a luz dos estudos de Riva (2015), Fonseca (2013), Mota e Maués (2014), Torres (2013) etc. -, a necessidade de se reavaliar o processo de implantação e funcionamento das políticas públicas educativas no Brasil, buscando refletir sobre novas estratégias para torná-las mais eficazes e eficientes com o propósito de melhorar a qualidade do ensino. A partir dessas discussões teóricas, observou-se ainda que, embora já esteja ocorrendo algum avanço no processo de mudança de concepções nesse sentido, faz-se necessário implantar políticas educacionais que sejam melhor elaboradas, planejadas e articuladas para, com isso, alcançar a qualidade esperada na educação pública.

Nessa análise, ressaltou-se, principalmente, a necessidade de se reavaliar as iniciativas voltadas a alfabetização e a formação de leitores (Yunes, 1994; Micotti, 2009), como estratégia político-social para garantir, a todas as crianças e adolescentes inseridos na escola pública, o direito de alfabetizar-se e letrarse plenamente, desenvolvendo-se intelectual e socialmente (Albuquerque, 2007; ROJ0, 2010), pois, entendeu-se que instituir políticas públicas de alfabetização e formação de leitores é propiciar as condições básicas para que o "poder público possa atuar sobre a democratização das fontes de informação, sobre o fomento da leitura e à formação de alunos e professores leitores"(Berenbluum e Paiva, 2006, p. 09), com o objetivo de garantir a todos o direito de estar plenamente preparado para usufruir os benefícios trazidos pela cultura letrada, exercendo com dignidade sua cidadania.

Esse entendimento fortaleceu-se com as palavras de Rangel (2010, p.184) ao dizer que não há cidadania efetiva, nem inclusão social de fato, sem que haja uma adequada educação escolar, que priorize a qualidade da alfabetização e da formação leitora como caminho para transformar os indivíduos em cidadãos autônomos, críticos e participativos. Ao desenvolver os dois primeiros capítulos, uma das preocupações era estar sempre refletindo e analisando, dentro das discussões, a relevância do papel do professor em diferentes épocas, apontando-a como uma importante ferramenta para propiciar a transformação da realidade educativa e social (Orso, 2008; Gadotti, 2012).

Por fim, no terceiro e último capítulo, optou-se em apresentar o passo a passo da investigação, oferecendo breves informações sobre o programa (ICEP) e sobre a realidade educativa do município em que este foi implantado(QEDU, 2015; Brasil, 2017) dando ênfases aos resultados alcançados por meio dos procedimentos metodológicos utilizados.

\section{RESULTADOS E DISCUSSÃO}

Por meio da observação sistemática (Lakato e Marconi, 2006) do espaço e do processo formativo que ocorreu cerca de três meses, presenciou-se alguns fatos e situações, mostrando que o principal objetivo do programa de formação docente pesquisado seria o de ajudar o professor a entender a importância de, cotidianamente, repensar e reavaliar a prática de ensino, observando os acertos e equívocos cometidos no processo de ensino-aprendizagem da leitura e da escrita

Com esse objetivo, o programa procurou ampliar o conhecimento teórico dos docentes de Língua Portuguesa, oferecendo-lhes a oportunidade de experimentar, por meio das oficinas desenvolvidas, novas possibilidades de ensino voltadas ao processo de letramento e de formação leitora, que tinham a finalidade de despertar e fomentar o desejo de aprender dos alunos inseridos no contexto educativo correspondentes aos anos finais do FII ${ }^{16}$. No entanto, essa proposta teórico-metodológica do programa, não foi entendida de imediato pelos professores, talvez, porque, naquele momento, as concepções e expectativas relacionadas ao ensino-aprendizagem da leitura/escrita aparentemente fossem diferentes das apresentadas pelo Programa.

Para os professores participantes, aquela formação deveria englobar não, somente, aos conhecimentos teóricos sobre como intensificar as práticas de letramentos no Ensino fundamental II (FII), mas, deveria, também, oferecê-los orientações mais concretas sobre como alfabetizar os alunos que chegam àquela etapa da escolarização, ainda, em condição de semianalfabetos. Para a maior parte das participantes que ali estavam, especialmente para o grupo que trabalhava com os sextos anos, o que interessava, naquele momento, não era saber inicialmente, como letrar, ou formar leitores - mas descobrir como resolver a

\footnotetext{
${ }^{16}$ Anos finais do Ensino Fundamental.
} 
questão do semianalfabetíssimo que, há alguns anos, vem comprometendo o processo de ensino aprendizagem dentro do município. Um problema que segundo o grupo pesquisado, afeta, principalmente os alunos dos sextos anos, por ser uma etapa de escolarização intermediaria, que compreende o término da etapa inicial e o início da etapa final do ensino fundamental.

Esse embate de percepções revelou que, dentro daquele contexto formativo, as convergências não estavam somente na questão do ensinar ou não novas estratégias para que os professores alfabetizassem seus alunos semianalfabetos no FII, estavam, sobretudo, no modo como o Programa e os professores entendiam esse processo de construção do sujeito-leitor, pois, enquanto que para o primeiro o termo alfabetizar era percebido como um processo contínuo que deveria ser atrelado ao letramento, para os professores em formação, naquele momento, estava sendo entendido como um processo isolado, independente da ideia de letramento.

Esses debates mostraram que, embora houvesse apresentado e discutido o sentido dos termos alfabetização e letramento no primeiro encontro formativo, muitos, ainda, precisaram de um bom tempo para compreender que os referidos processos se completavam e deveriam ocorrer paralelamente, ou seja, não entenderam de imediato que enquanto a alfabetização é a "apropriação das operações de um código a língua escrita, com seus mecanismos de leitura e escritura, complementarem entre si” (Saraiva, 2001, p 23) e o letramento é "o envolvimento progressivo do aluno em práticas sociais de leitura e escrita" que pode estimular esse processo de apropriação (Rangel e Rojo, 2010, p. 11).

Esse fato serviu para mostrar que, embora essa questão pareça ser um assunto saturado, ainda, se faz necessário, nos cursos de formação direcionados a professores de Língua portuguesa do FII, discutir um pouco mais sobre os termos alfabetização e letramento, para fortalecer a ideia de que é possível trabalhar, na sala de aula, utilizando estratégias de ensino que mesclem esses dois processos, pois assim, os docentes em formação poderão ter a oportunidade de conhecer, refletir e debater um pouco mais sobre a proposta da pedagogia do alfabetizar-letrando (Soares, 2002; Franchi, 2012) e, com isso, possivelmente, poderão adquirir uma compreensão mais ampla sobre esse tema, evitando futuras contestações quando esse assunto for posto em pauta.

Durante o processo de observação e análise dos dados qualitativos, foi possível perceber que para tentar alcançar o objetivo de melhorar a formação leitora dos alunos dos sextos anos, as docentes pesquisadas ${ }^{17}$ tiveram, antes, que superar algumas dificuldades para pôr em prática os conhecimentos adquiridos na formação. Elas perceberam que junto ao desafio de melhorar o processo de ensino-aprendizagem estaria a obrigação de aprender a lidar com os sentimentos de insatisfação e de decepção por, nem sempre, encontrarem, dentro do contexto escolar, o apoio esperado para executarem com eficiência todas as sugestões apresentadas no curso de formação. A falta de materiais didático-pedagógico, de infraestrutura das instituições e, até mesmo a omissão por parte da gestão escolar foram razões citadas para que, em alguns momentos, as respondentes se sentissem desmotivadas em continuarem a participar da formação.

Em seus relatos, cada uma das docentes pôde oferecer elementos que contribuíram na reflexão sobre um outro fato observado que merecia ser destacado na pesquisa: A pouca participação de docentes no curso de formação ${ }^{18}$. A partir desses depoimentos, em que se externaram insatisfações e descontentamento, levantou-se a hipótese de que, talvez, uma das razões para a baixa participação no curso de formação fosse, justamente, a desmotivação dos docentes (não participantes) em ter que enfrentar essas mesmas dificuldades.

Contudo, nessa compreensão, não se desprezou, em nenhum momento, a possibilidade de que, junto a isso pudesse também ter ocorrido, por partes destes, o descomprometimento profissional, que inviabilizou o processo de transformação positiva da realidade pessoal e coletiva. Uma hipótese que, se confirmada, demostraria que esses docentes ainda não precisavam desenvolver sua consciência político-social (ORSO, 2008; Gadotti, 2012), por isso, perderam a oportunidade de renovar seus conhecimentos e experimentar novas práticas de ensino da leitura e da escrita que oportunizassem uma aprendizagem mais significativa para seus alunos. Essa situação revela o quanto, ainda, faz-se necessário investir em políticas públicas que garantam não somente a formação do educando, mas que, também, se preocupe com a condição de

\footnotetext{
17 Após o período de observação sistemática, selecionou-se, no grupo de 12(doze) participantes, as três únicas professoras dos sextos anos, devido ao fato de que essas lecionavam nas três maiores instituições de ensino do município.

${ }^{18}$ De acordo com as informações coletadas em questionários, o município havia disponibilizado 55 (cinquenta e cinco) vagas para essa formação, mas, apenas, 25 (vinte e cinco) professores tiveram o interesse em se inscrevem. Destes, apenas, 12 (doze) permaneceram e concluíam o curso.
} 
trabalho do docente, pois, é a partir dele que são criadas as condições necessárias para ajudar os educandos a superar suas dificuldades de aprendizagem.

No decorrer da pesquisa, entendeu-se que, apesar de ter sido observado alguns pontos de convergência durante o processo formativo, a análise dos dados qualitativos mostrou que, ao término do processo, as docentes participantes já reconheciam que a proposta do Programa ICEP trouxe benefícios significativos para seu desenvolvimento intelectual e profissional. Para elas, a oportunidade de participarem das atividades de debates, reflexão em grupo e troca de experiência foi importante para ajudá-las a compreender que no processo de formação leitora, faz-se necessário o constante exercício da reflexão e da autoavaliação e o reconhecimento de que no erro cometido abre-se novas oportunidades para reaprender a reorganizar a prática pedagógica, pois, somente assim, é possível tornar-se um profissional qualificado para formar leitores competentes.

As respondentes afirmaram que, ao fim do processo formativo, passaram a ter uma maior consciência sobre o quanto os conhecimentos adquiridos foram fundamentais para dar um novo sentido a sua prática educativa a ponto de fazê-las driblarem todas a dificuldades impostas para, dentro dos seus limites, conseguirem criar estratégias de ensino que fossem mais atrativas, não somente, para os alunos alfabetizados, como, também, para os semianalfabetos que, ao se integrarem às atividades propostas, passaram a demostrar mais interesse em aprende a ler e escrever. Segundo as pesquisadas, ao inovarem sua prática de ensino, conseguiram fazer com que todos os seus alunos despertassem a curiosidade sobre o texto escrito, aumentando neles o gosto/prazer pela leitura e pela escrita. E, como resultado, desse processo, houve um crescimento significativo das práticas de leitura dentro das salas de aula, tanto pelos alunos quanto pelas próprias professoras.

De acordo com a percepção das respondentes, com a mudança de concepções e a inovação na prática pedagógica, abriu-se novos espaços para o diálogo e para a escuta (entre professores-alunos, aluno-aluno bem como entre os membros da comunidade escolar) e, com essas alterações na rotina da sala de aula, todos os alunos passaram a perceber o quanto era fundamental ter proficiência em leitura/escrita para poder discutir, questionar e compartilhar informações e conhecimentos que, possivelmente, os ajudariam a estar sempre, conectados as demandas da sociedade atual.

Assim, entendeu-se que o referido programa - embora não tenha alcançado plenamente seu objetivos inicial de formar todos os docentes de Língua portuguesa da rede - pode, ao menos, contribuir para alterar a concepção daqueles que participaram, influenciando positivamente no processo de formação leitora dos seus alunos, uma vez que, ao promover essas alterações de posicionamento, incentivou novas práticas educativas que propiciaram construir um espaço educativo mais democrático, em que todos alunos foram estimulados a reconhecer o valor social da leitura e da escrita e, gradativamente, a avançar em seu processo de formação leitora, especialmente, aos que se encontravam na condição de semianalfabetos, que passaram a ter garantido o direito, por meio do acesso à leitura e a escrita, também, poder elevar seu nível de alfabetismo e aprender.

\section{CONSIDERACÕES FINAIS}

A presente investigação mostrou o quanto foi imprescindível para o município de Xique-Xique/BA conseguir implantar uma política de formação docente, pois ela, contribuiu para que houvesse uma significativa modificação de concepções e práticas de ensino voltadas à leitura e a escrita. Graças a essa política de formação, os docentes participantes despertaram a consciência da importância do seu papel político-social no processo de elevação da qualidade da formação leitora e educativa dentro do município.

Sendo assim, pode-se afirmar que, embora a proposta do Programa não tenha alcançado plenamente seu objetivo de capacitar todos os professores de Língua Portuguesa da rede, ela, ao menos, conseguiu fazer com que as docentes participantes se integrassem e se identificassem nas dificuldades e limitações, estimulando nessas o desejo de enfrentar as adversidades do contexto escolar, entendendo que a atualização dos conhecimentos, ainda, é a única forma de assegurar a transformação da realidade educativa e alterar a condição dos seus alunos como sujeitos-leitores.

Assim, a partir do que foi discutido, conclui-se que a referida pesquisa trouxe reflexões e questionamentos que, certamente, abrirão espaços para novas hipóteses, reflexões e indagações sobre processo investigado, contribuindo, possivelmente, para que o entendimento sobre o assunto abordado seja, ainda, complementado, questionado ou fortalecido. Portanto, ao assumir sua função social, o presente estudo tornou-se um importante instrumento para indicar caminhos que poderão ser seguidos na busca pelo 
melhoramento da qualidade educativa dos docentes e dos discentes, não somente no município pesquisado, mas em todas as cidades brasileiras.

\section{REFERÊNCIAS}

[1] Albuquerque, Eliana Borges Correia de. Conceituando alfabetização e letramento. In Santos, Carmi Ferraz e Mendonça Márcia. Alfabetização e letramento: conceitos e relações. Belo Horizonte: Autêntica, 2007.

[2] Alquéres, Humberto. Por uma nação de leitores. In: Amorim, Galeno. Retrato da leitura no Brasil. São Paulo: Instituto Pró livro, 2008.

[3] Berenblum, Andréa; Paiva, Jane. Por uma política de formação de leitores. Brasília: Ministério da Educação, Secretaria de Educação Básica, 2006. Disponível em: http://www.cultura.al.gov.br/politicas-e-acoes/sistemaestadual-de-bibliotecas-publicas/leituras-recomendadas/100_por_politica_formacao_leitores_v1.pdf.

[4] Brasil. Instituto Brasileiro de geografia e estatísticas. Cidades @ Bahia Xique-Xique. 2016. Disponivel em: http://cidades.ibge.gov.br/xtras/perfil.php?lang=\&codmun=293360\&search=bahia|xique-xique. Acesso. 29 de Julho de 2017.

[5] Chartier, Roger. Do córtex à tela: as trajetórias do escrito. In: A ordem dos livros: leitores, autores e bibliotecas na Europa entre os séculos XIV e XVIII. Brasília, DF: UNB, 1994. p. 95111.

[6] Fonseca, Marília. O Banco Mundial e a educação: reflexões sobre o caso brasileiro. In Gentilli, Pablo. Pedagógica da Exclusão: crítica ao neoliberalismo em educação. 19. ed. Petrópolis, RJ: Vozes, 2013.

[7] Freire. Paulo. A importância de ler: em três artigos que se completam. 28. ed. São Paulo: Cortez, 1993.

[8] Franchi, Eglê. Pedagogia do alfabetizar letrando: da oralidade à escrita. 9. ed. São Paulo: Cortez, 2012.

[9] Gadotti, Moacir. Concepção dialética da educação: um estudo introdutório. 16. ed. São Paulo: Cortez, 2012.

[10] Icep, Instituto Chapada de pesquisa. Disponível em:<http://institutochapada.org.br/>. Acesso: 02 de Fevereiro de 2017.

[11] Lakato, Eva Maria; Marconi, Mariana de Andrade. Metodologia Científica. 4. ed. São Paulo: Atlas, 2006.

[12] Micotti, Maria Cecília de Oliveira. O Ensino Fundamental: Políticas Públicas e prática pedagógica. In Micotti, Maria Cecília de Oliveira. Leitura e escrita. São Paulo: Contexto. 2009.

[13] Mota, William Pessoa e Maués, Olgaíses Cabral. Banco Mundial e as Políticas Educacionais Brasileiras. Universidade Federal do Pará (UFPA), Belém/PA - Brasil. Disponível em: http://www.scielo.br. Acesso: 18 de Março de 2017.

[14] Moreira, Marco Antônio. Teoria da aprendizagem. São Paulo: EPU, 1999.

[15] Orso, Paulino José. A educação na sociedade de classes: possibilidades e limites. In Orso et al. Educação e lutas de classes. São Paulo: Expressão popular. 2008.

[16] Perroti, Edmir. Leitores, ledores e outros afins: apontamentos sobre a formação do leitor. Disponível em http://www.leiabrasil.org.br. 1999. Acesso em 28 de Março de 2017.

[17] Prestes, Maria Lúcia de Mesquita. A pesquisa e a construção do conhecimento cientifico: do projeto ao texto, da escola à academia. 3. ed. São Paulo. 2010.

[18] Rangel, Egon de Oliveira; ROJO, Roxana Helena Rodrigues. Língua Portuguesa: ensino fundamental. Coleção explorando o ensino. Brasília: Ministério da Educação. 2010.

[19] Rangel, Egon de Oliveira, Educação para o convívio republicano: o ensino de Língua Portuguesa pode colaborar para a construção da cidadania? In: Rangel, Egon de Oliveira, Rojo, Roxane Helena Rodrigues. Língua Portuguesa: Ensino fundamental. Brasília: Ministério da educação. 2010

[20] Rivas, Axel. Educação I. Título CDD 370. Cidade Autônoma de Buenos Aires: Fundação Cippec. 2015.

[21] Rojo, Roxane Helena Rodrigues. Alfabetização e letramentos múltiplos: como alfabetizar letrando? .In: Rangel, Egon de Oliveira, ROJO, Roxane Helena Rodrigues. Língua Portuguesa: ensino fundamental. Brasília: Ministério da educação. 2010.

[22] Saraiva, Juracy Assmann. A situação da leitura e a formação do leitor. In, Literatura e alfabetização; do plano do choro ao plano da ação. Porto Alegre: Artmed. 2001.

[23] Soares, Magda. Letramento: um tema em três gêneros. 2. ed. Belo Horizonte: Autêntica. 2000. 
[24] Torres, Carlos Alberto. Estado, Privatização e políticas Educacionais: elementos para uma crítica ao neoliberalismo. In Gentilli, Pablo. Pedagógica da Exclusão: crítica ao neoliberalismo em educação. 19. ed. Petrópolis, RJ: Vozes, 2013.

[25] Yunes, Eliane. Políticas de formação do leitor: por uma política nacional de leitura. In: Ministério da Educação e do Desporto. A Formação do leitor: o papel das instituições de formação do professor para a Educação fundamenta. São Paulo: Editora Moderna Ltda. 1994.

[26] Xavier, Carlos Antônio. Leitura, texto e hipertexto. In Marcuschi, Luiz Antônio \&. Hipertexto e Gêneros digitais: novas formas de construção do sentido. Rio de Janeiro: LucerEDU. Sobre o Qedu. 2017. Disponível em: www.qedu.org.br/. Acesso: 20 de Agosto de 2017. 


\section{Capítulo 10}

Fatores associados à ansiedade: 0 que expressam alunos de um curso de licenciatura em Ciências Biológicas

\section{Lucas de Pádua da Silva Maia \\ Vinícius Carvalho Pereira \\ Andreza Alencar Colares Botêlho \\ Jeanne Barros Leal de Pontes Medeiros}

Resumo: A saúde mental dos estudantes universitários tem despertado a atenção de diversas pesquisas, demonstrando a importância de se avaliar as condições psicológicas dos alunos no decorrer da graduação. Este trabalho teve como objetivo avaliar os fatores associados ao nível de ansiedade dos estudantes do curso de Ciências Biológicas da Universidade Estadual do Ceará (UECE). Para isto, realizou-se uma pesquisa de natureza qualiquantitativa com 9 estudantes de diferentes semestres do curso. Para tanto, utilizou-se o Inventário de Ansiedade de Beck (BAI) e foram feitas entrevistas semiestruturadas com os estudantes. Observou-se que os estudantes apresentaram o grau mínimo e moderado de ansiedade, havendo uma maior prevalência de estudantes do sexo feminino com o nível moderado. Os sujeitos apontaram como principal motivador das crises de ansiedade e situações de desconforto, a má relação professor/aluno dentro do curso. Os resultados apontam para a necessidade de reavaliação das situações geradoras de ansiedade dentro do curso, com o intuito de gerar uma melhora no bem-estar e no desenvolvimento da aprendizagem dos estudantes do curso.

Palavras-Chave: Ansiedade. Aprendizagem. Universitários. 


\section{INTRODUÇÃO}

A saúde mental dos estudantes universitários tem despertado a atenção de diversas pesquisas, demonstrando a importância de avaliar as condições psicológicas dos alunos ao decorrer da graduação. Isso acontece devido ao aumento de complicações psiquiátricas neste público, uma vez que ao longo do percurso acadêmico o estudante encara diversas situações que podem ocasionar momentos de esgotamento emocional e físico (BRANDTNER; BARDAGI, 2009; SILVEIRA et. al., 2011; MEDEIROS; BITTENCOURT, 2017).

A ansiedade é uma situação que faz parte do desenvolvimento normal do ser humano, porém quando a mesma se apresenta de maneira desproporcional ao evento conflitante e acaba influenciando na qualidade de vida do indivíduo, pode ser considerada patológica (CASTILLO et al., 2000; BAPTISTA; CARVALHO; LORY, 2005; CARVALHO; et al., 2015).

Além de afetar o bem-estar psicológico dos estudantes, os níveis elevados de ansiedade dificultam o processo de aprendizagem uma vez que acaba interferindo sobre alguns aspectos cognitivos do aluno, como uma tendência de questionar suas habilidades intelectuais, interferindo na absorção de informações na memória e levando a um bloqueio na compreensão (BARDAGI; HUTZ, 2011; OLIVEIRA; DUARTE, 2004; OLIVEIRA et al., 2006).

No curso de Licenciatura em Ciências Biológicas é comum testemunhar estudantes falando sobre o peso da rotina da graduação e as consequentes aflições geradas. Dentre os relatos dos colegas de curso estão: sensação constante de sobrecarga, de crises de choro, mudanças nos padrões de sono, nervosismo recorrente, altos níveis de stress, sentimento de incapacidade, dentre outros. E sobre isso, Marchi et al. (2013), afirmam que, apesar de o período de graduação oferecer sentimentos positivos, eventualmente transforma-se num período crítico e de vulnerabilidade para os estudantes.

Dessa forma, o presente estudo tem como objetivo avaliar os fatores associados ao nível de ansiedade dos graduandos do curso de Ciências Biológicas da Universidade Estadual do Ceará. 0 trabalho foi apresentado na modalidade oral, no VI CONEDU (Congresso Nacional de Educação).

\section{METODOLOGIA}

A pesquisa foi realizada na Universidade Estadual do Ceará (UECE), na cidade de Fortaleza (CE), no ano de 2018. Participaram da pesquisa 9 alunos do curso de Licenciatura em Ciências Biológicas. Os critérios utilizados para a inclusão de sujeitos foram: indivíduos de ambos os sexos, sem especificação de idades, que aceitaram participar do estudo e que estão regularmente matriculados no curso. A cada estudante foi dado um nome fictício, resguardando a identidade dos mesmos.

Optou-se pelos métodos quantitativo e qualitativo. Sendo o método quantitativo ancorado pela utilização do Inventário de Ansiedade de Beck (Beck Anxiety Inventory - BAI), que segundo Santos (2014) é composto por 21 itens que avaliam sintomas de ansiedade. 0 nível de ansiedade dos estudantes é dado pela somatória dos escores individuais que varia de 0-3. 0 resultado final do inventário pode variar entre 0-63 (0-10, Mínimo; 11-19, Leve; 20-30, Moderado; 31-63, Grave).

Os dados obtidos foram organizados numa tabela na qual foram separados em colunas de acordo com o semestre, o sexo, a pontuação no BAI e seu respectivo grau de ansiedade de acordo com o inventário. Em seguida, foram expressas por meio de gráfico com as porcentagens dos níveis de ansiedade dos estudantes de acordo com o semestre.

No método qualitativo foi utilizada entrevista semiestruturada, que, de acordo com Brito Júnior e Feres Júnior (2011) é uma estratégia para dirigir de maneira eficaz um conteúdo sistemático de conhecimentos sobre as questões levantadas. Os dados obtidos a partir das entrevistas foram transcritos e depois segmentados em eixos temáticos, afim de identificar os principais temas citados pelos sujeitos.

\section{RESULTADOS E DISCUSSÕES}

Para análise quantitativa dos dados, obtidos a partir do Inventário de Ansiedade de Beck, observamos os níveis de ansiedade apresentados pelos estudantes na Quadro 1. 
Quadro 1 - Níveis de ansiedade dos estudantes avaliados pelas variáveis: Semestre, Sexo e Pontuação.

\begin{tabular}{|c|c|c|c|c|c|c|c|c|c|}
\hline Semestre & $2^{\circ}$ & $4^{\circ}$ & $1^{\circ}$ & $2^{\circ}$ & $1^{\circ}$ & $3^{\circ}$ & $2^{\circ}$ & $3^{\circ}$ & $1^{\circ}$ \\
\hline Sexo & Feminino & Masculino & Masculino & Masculino & Feminino & Masculino & Femínino & Masculino & Masculino \\
\hline Pontuação & 21 & 16 & 9 & 5 & 26 & 27 & 45 & 11 & 1 \\
\hline $\begin{array}{c}\text { Grau de } \\
\text { ansiedade }\end{array}$ & Moderado & Leve & Minimo & Minimo & Moderado & Moderado & Severo & Leve & Minimo \\
\hline
\end{tabular}

Fonte: Elaborado pelos autores.

Tratando-se da porcentagem geral, 33,3\% (3) dos estudantes apresentaram grau mínimo de ansiedade, $22,2 \%$ (2) grau leve de ansiedade, 33,3\% (3) grau moderado de ansiedade e 11,1\% (1) apresentou grau severo d ansiedade. Assim, observamos a prevalência de dois graus de ansiedade: Mínimo e Moderado. Porém, deve-se destacar que 11,1\%, referente a 1 aluno, apresenta o grau de ansiedade mais grave.

A prevalência dos sintomas ansiosos em alguns estudantes deve ser acompanhada com atenção pela instituição de ensino, uma vez que a ansiedade, quando em intensidade excessiva deixa de ser um fator que proporciona o desempenho e passa a ser prejudicial tanto nos aspectos acadêmicos como em sua qualidade de vida (LANTYER et al., 2016).

Os níveis de ansiedade por semestre são apresentados no gráfico 1. Para cada semestre, foi calculada uma média de pontuação no BAI: $1^{\circ}$ semestre -12 pontos, $2^{\circ}$ semestre 23,6 pontos, $3^{\circ}$ semestre -19 pontos e 4 o semestre -16 pontos.

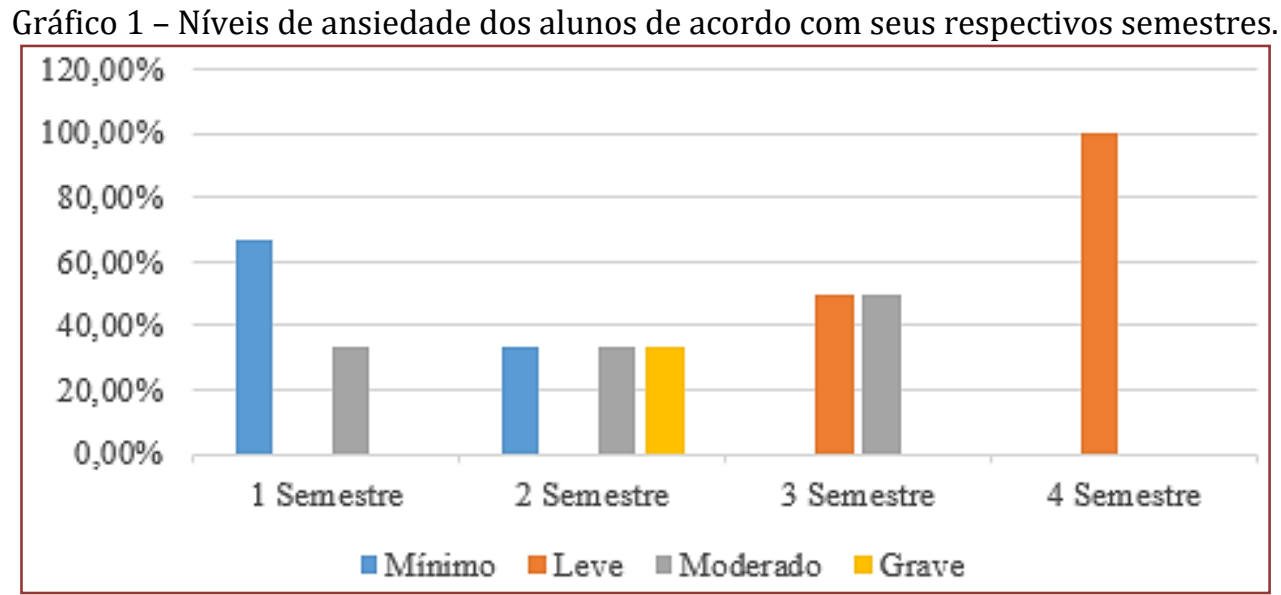

Analisando os dados junto ao gráfico, observamos a prevalência dos maiores níveis ansiosos nos estudantes do $2^{\circ}$ semestre do curso, sendo que 33,3\% dos estudantes apresentam o nível mínimo de ansiedade, 33,3\% apresenta o nível moderado e os 33,3\% restantes apresentam o maior nível de ansiedade, o severo. Vale ressaltar que os demais semestres, como o $1^{\text {o }}$ e o $3^{\text {o }}$ também apresentaram o nível moderado de ansiedade, sendo o $1^{\mathrm{o}}$ semestre com o maior índice de estudantes com nível de ansiedade mínima, representado por $2 / 3$ dos alunos. $04^{\circ}$ semestre, é composto apenas por um nível de ansiedade, o leve.

As entrevistas com os estudantes foram alocadas em 3 eixos temáticos: ingresso no curso, motivadores de ansiedade e impacto da ansiedade na aprendizagem, descritos a seguir.

Ingresso no Curso:

\section{Satisfação com o Curso}

Os relatos dos entrevistados evidenciam que a maioria dos estudantes se encontram satisfeitos com o curso, porém, a partir dos padrões de respostas, podemos dividir sistematicamente os estudantes em dois grupos. Os que dizem estar satisfeitos com o curso relatam: 
Mia ( $2^{\circ}$ semestre): “Criei muita expectativa quanto ao curso e minhas expectativas estão sendo supridas, estou na universidade que eu queria, no curso que eu queria, fazendo a modalidade que eu queria, então eu estou bem feliz."

Lupita ( $1^{\circ}$ semestre): "Sim. Estou fazendo o que sempre quis, e o pessoal é muito acolhedor. E também no primeiro semestre eles dão muita oportunidade para você se envolver com os projetos do curso, então é muito bom".

Langame et al. (2016) aponta que a satisfação com a vida acadêmica se relaciona com diversos aspectos, como senso de identidade, personalidade, rendimento acadêmico e satisfação com as atividades desenvolvidas no curso, sendo um fator essencial para o desenvolvimento do estudante como futuro profissional. Assim, a fala dos estudantes do primeiro grupo se enquadrou em alguns desses aspectos, como no senso de identidade e satisfação com as atividades desenvolvidas no curso. Além disso, de acordo com Ramos et al. (2015), a satisfação acadêmica se associa à qualidade da aprendizagem dos estudantes e sua avaliação é essencial para as instituições de ensino, pois fornece subsídios para a melhoria da qualidade do ensino dos cursos de uma instituição.

\section{Atividades Complementares}

Santos et al. (2013) e Abrão (2015) afirmam que a participação dos estudantes em atividades extracurriculares é muito importante na formação dos universitários, além de permitirem a flexibilização e contextualização do currículo, sendo percebida pelos próprios alunos como um diferencial para sua vida pessoal e profissional.

Sob esse aspecto, a maioria dos estudantes informou estar envolvido em mais de uma atividade extracurricular:

Mia ( $2^{\circ}$ semestre): "Eu faço parte da Empresa Júnior da Biologia - HARPIA e sou bolsista do PIBID."

León ( $4^{\circ}$ semestre): "Participo de 2 laboratórios."

Téo (1ํㅗ semestre): "Por enquanto, só o PET.".

Miguel ( $3^{\circ}$ semestre): "Eu sou bolsista do Pet e sou consultor administrativo financeiro na Harpia."

As falas demonstram a realidade levantada Sampaio (2011), quando afirma que as disciplinas da graduação não são os únicos compromissos universitários, pois existem outros aspectos da vida no campus, dentre eles a responsabilidade com as atividades extracurriculares.

\section{Mudanças de Hábitos}

Carlotto, Teixeira e Dias (2015) destacam que nos anos iniciais diversas mudanças são geradas no cotidiano dos ingressos, os estudantes passam a enfrentar desafios pontuais que, além do âmbito acadêmico, envolvem os âmbitos social, pessoal, institucional e vocacional.

A análise das respostas obtidas demonstra mudanças nas horas de sono dos jovens, além de alterações nas atividades de lazer e nas atitudes pessoais dos mesmos.

Mia ( $2^{\circ}$ semestre): "Estou tendo problemas com minhas horas de sono. Já cheguei a dormir às 3 e acordar às 5. E em relação às atividades de lazer, abro mão de sair para fazer algo da faculdade, Harpia ou Pibid, mas como gosto dessas coisas, sinto que são trocas."

León (4ํㅜ semestre): “Agora sou mais responsável, sou menos dependente dos outros. Quanto ao sono, sempre dormi pouco até porque tinha problemas de insônia, mas já resolvi. Na faculdade, depois que entrei, durmo em média 5 horas por dia."

Giovanni ( $2^{\circ}$ semestre): "No final do semestre durmo menos, as vezes dormia de madrugada para acordar de manhã cedo de novo, dormindo 1 ou 2 horas."

Miguel ( $3^{\circ}$ semestre):"Eu acho que eu estou saindo bem mais depois que entrei no curso, mais pelo fato de ter conhecido pessoas que gostam mais de sair, e a bolsa também me propiciou isso, eu tenho dinheiro agora para poder sair."

Roberta ( $2^{\circ}$ semestre): “Agora preciso escolher, mas tento manter a vida social. "

Diego ( $3^{\circ}$ semestre): "Viro a noite estudando, nesse semestre principalmente, eu estou mais cansado, estou me sentindo desestimulado." 
Sobre esse aspecto, Almondes e Araújo (2003) alertam sobre a interação entre as alterações nas horas de sono e o comportamento emocional, mais precisamente, entre o sono e a ansiedade. Uma rotina de sono desregulada pode acarretar, além de estados ansiosos, o cansaço, perda da concentração, fadiga, nervosismo, ideias irracionais, perda de apetite, entre outros (SANTOS, 2014).

Em relação às mudanças nas horas de lazer, observamos estudantes que se privaram de fazer determinadas atividades ou tiveram que redistribuir melhor seu tempo, e estudantes que afirmam ter aumentado suas horas de lazer. Apesar dos dois padrões observados, ambas as afirmativas apontam que os estudantes mudaram seus hábitos, principalmente, nesse caso, se tratando dos aspectos sociais, o que ratifica as afirmativas de Carlotto, Teixeira e Dias (2015) que afirma que esses estudantes, em diversos momentos da graduação, passam por mudanças, inclusive no que diz respeito aos aspectos sociais, sendo essa mudança e gestão de tempo, um desafio para os alunos de graduação. Porém, foi possível perceber entre alunos do primeiro semestre que não houve mudanças significativas da rotina dos mesmo sem virtude da graduação.

\section{Motivadores da Ansiedade: \\ Administração do tempo}

De acordo com Bardagi e Hutz (2011), a ansiedade e a dificuldade de administração do tempo são os principais responsáveis do estresse acadêmico. Os relatos da pesquisa evidenciam que um grupo de estudantes consegue conciliar bem seu tempo entre as atividades realizadas pelos mesmos.

Mia ( $2^{\circ}$ semestre): “Concilio bem meu tempo, tem momentos que eu me sinto sufocada, mas geralmente eu estou bem em relação às minhas atividades."

Téo (1ํㅜ semestre): "Acho que concilio bem meu tempo, relativamente, consigo cumprir minhas atividades.".

Roberta ( $2^{\circ}$ semestre): "Eu acho que consigo conciliar."

Diego ( $3^{\circ}$ semestre): "Neste semestre? (Risos). Esse semestre foi complicado, mas sim, estou conseguindo conciliar meu tempo."

A fala desses estudantes "conversam" com as respostas acerca da participação em atividades complementares, alguns até tomam a participação nas atividades como um dificultador no cumprimento das atividades advindas das disciplinas, reafirmando mais uma vez as ideias de Sampaio (2011), de que a gerência dessas demandas acadêmicas são um desafio contínuo para o universitário.

Mas um segundo grupo é composto por alunos que acreditam não conciliar bem o tempo, devido ao trabalho concomitante com a graduação.

A administração do tempo pode constituir uma das vivências que gera maior dificuldade quando o estudante ingressa no ensino superior, e essa dificuldade pode ser ainda maior para os estudantes que trabalham, visto que precisam conciliar as atividades exigidas no trabalho, nos estudos e em outros contextos presentes em suas vidas (OLIVEIRA; TEIXEIRA; CARLOTTO; DIAS, 2016).

Percebe-se também nas falas a dificuldade de conciliar o tempo devido ao excesso de atividades da universidade para fazer, como, por exemplo:

Giovanni (2o semestre): “Quando participava de um laboratório, conseguia conciliar mais ou menos o meu tempo, eu me sentia com muita coisa para fazer e não tinha tempo para fazer, era muito cansativo, aí só fazia mais dormir. Eu até me sentia um pouco culpado."

Através dessa fala, retomamos para a afirmativa de Sampaio (2011) acerca da importância da gestão das atividades, porém se inclui a ideia procrastinação, também abordada pelo estudante, sendo essa procrastinação, de acordo com Ackerman e Gross (2005), muito difundida dentro de um contexto acadêmico, os autores também afirmam que vários estudos revelam que a procrastinação afeta cerca de $50 \%$ a $95 \%$ dos alunos de graduação.

\section{Disciplinas}

Segundo Santos (2014), o período de ingresso, como estudante, em instituições de ensino superior pode fazer com que os jovens vivenciem um período de crise, pela exigência em se adaptar a um novo papel social, além disso, de acordo com Sampaio (2011), grande parte das disciplinas oferecidas no ensino superior tem caráter denso e, muitas vezes, exigem a realização simultânea de inúmeras atividades. 
Sobre as disciplinas, os estudantes apresentaram testemunhos variados. 0 primeiro grupo de estudantes afirma ter vivenciado crises de ansiedade ou situações de desconforto relacionados a algumas disciplinas no curso e durante os relatos, alguns estudantes se emocionaram lembrando de algumas situações vivenciadas pelos mesmos.

Mia ( $2^{\circ}$ semestre): "Nas disciplinas de Bioquímica e Cálculo. Eu acredito que não tenha sido uma crise de ansiedade, mas para mim, se uma disciplina me faz chegar em casa e chorar, já me mostra que alguma coisa está errada."

Miguel ( $3^{\circ}$ semestre): "No primeiro (semestre) foi química, mas acho que não foi culpa da cadeira, porque eu achava que estava muito mal, mas eu não. No segundo semestre, foi mais por motivos pessoais, aí influenciou numa cadeira que estava com muita dificuldade. Esse semestre, eu já tive problema com mais de uma cadeira, biomol (Biologia Molecular) principalmente, mas por questão de dificuldades com o jeito que a professora ensinava, com algumas coisas que ela fazia e isso me deixou bem mal em alguns momentos."

Roberta ( $2^{\circ}$ semestre): “Em todas as cadeiras eu tive algum momento de desconforto... Eu tenho ansiedade, então eu tive crise de ansiedade antes de uma apresentação. Eu tive crise de ansiedade em casa por causa de bioquímica."

Giovanni ( $2^{\circ}$ semestre): "Não, mas conheço amigos que passaram por isso. Uma amiga minha foi apresentar um seminário e o professor a tratou mal na frente de todos, ela começou a chorar na frente da turma e teve uma crise, não conseguia falar. Em biofísica muita gente trancou, pois, achou que ia reprovar, tinha com gente que sentia dificuldade para respirar, estavam muito nervosos. "

A vida de estudantes universitários conta com diversos fatores ansiogênicos, sendo esse grupo muito propício ao desenvolvimento de ansiedade, podendo gerar sentimentos de desorganização, desesperança, tristeza, confusão e até pânico, dependendo do nível (SÁ; WERLANG; PARANHOS, 2008; MARCHI et al., 2013).

Outro grupo focou nas dificuldades que encontram em algumas disciplinas, seja pela metodologia de alguns professores ou pelas formas de avaliação.

Diego ( $3^{\circ}$ semestre): "Nas provas de Zoologia, que eu me mato de estudar e tiro nota baixa e é revoltante, estou com medo de reprovar, mas acho que crise, não."

Franco (1ํㅗ semestre): "Estou com um desconforto na cadeira de Biologia Celular, pois é a única que eu estou com dificuldade, tenho medo de ter que repetir."

Téo (1ํㅗ semestre): “Não, mas eu me sinto mal em psicologia, porque fico desconfortável com a metodologia da cadeira."

León ( $4^{\circ}$ semestre): “Acredito que não, não por causa da disciplina."

Lupita ( $1^{\circ}$ semestre): "Disciplina não... talvez um pouco da sobrecarga de tudo junto tenha causado algo do tipo, mas nada preocupante ou nada grave."

Devido à complexidade das disciplinas do curso, os estudantes frequentemente desenvolvem sentimentos de incapacidade frente às atividades exigidas durante sua formação profissional, como as avaliações, por exemplo. Isto pode fazer com que os mesmos possam desenvolver problemas originados da ansiedade e do estresse, como baixa capacidade de concentração e memorização, influenciando na diminuição do rendimento acadêmico (MONTEIRO; FREITAS; RIBEIRO, 2007).

As falas dos sujeitos evidenciam as afirmações levantadas, pois, segundo alguns trechos dos discursos, pode-se perceber sentimentos de desânimo e medo em relação a determinadas disciplinas, o que pode desencadear uma série de problemas afetando o desempenho dos mesmos.

Podemos concluir que quando o estudante constrói uma percepção de falta de capacidade para a realização das atividades de uma ou mais disciplinas, a base desses sintomas possui características da ansiedade e envolve o decréscimo de bons desempenhos (BORRALHA, 2012).

Busca de Especialistas e Uso de Medicamentos

Aos estudantes que acreditam ter vivenciado crises de ansiedade, perguntamos se os mesmos buscaram ajudas de especialistas para a resolução dos problemas. Dois dos 4 alunos que já haviam passado por crises não procuraram ajuda de um especialista, um aluno havia buscado e já se sentia melhor quanto à 
ansiedade e uma aluna havia buscado ajuda, porém, no momento, não estava em acompanhamento, mas tem a pretensão de retomá-lo.

A meta principal do acompanhamento terapêutico é auxiliar o indivíduo na recuperação do nível de funcionamento que possuía antes do evento que gerou a crise (SÁ; WERLANG; PARANHOS, 2008). Porém, de acordo com Santos (2014), apesar de 14\% a 19\% dos estudantes apresentarem algum transtorno psicológico durante a vida acadêmica, apenas um quarto procura ajuda profissional. Nossos dados apontam que $50 \%$ dos estudantes realizam essa procura, porém, devido ao pequeno número amostral, isso não invalida a afirmativa do autor.

Os mesmos estudantes foram perguntados sobre a utilização de medicamentos durante os períodos de crise, e obtivemos respostas semelhantes às que foram ditas na busca por especialistas. Os estudantes que não buscaram a ajuda de especialistas não se medicaram, contrariamente aos estudantes que buscaram ajuda e afirmaram ter utilizado medicamentos.

Marchi et al. (2013) informam que a busca pela adaptação ao âmbito acadêmico leva o indivíduo a utilização de psicofármacos, que muitas vezes ocorre de forma indevida. Não observamos essa predominância da utilização indevida de psicofármacos nos estudantes entrevistados, como visto nas falas acima, apenas os estudantes que tiveram um acompanhamento de um especialista realizaram o uso desses remédios, porém há a necessidade que se amplie o estudo e comtemple-se um maior número de estudantes para uma melhor averiguação dessa realidade nos estudantes do nosso curso.

\section{Impacto da Ansiedade na Aprendizagem:}

Ao serem perguntados sobre a ligação existente entre ansiedade e aprendizagem os alguns estudantes disseram que isso está mais ligado à relação professor-aluno. Brait et al. (2010) mostra que a relação professor-aluno depende do ambiente estabelecido pelo professor e da relação empática com seus alunos, criando pontes entre o seu conhecimento e o deles.

Na fala dos alunos percebe-se que a relação professor aluno é muitas vezes esquecida, o que pode gerar insatisfação, além de comprometer a aprendizagem dos estudantes, sendo essa realidade mais grave se considerarmos que acontece em um curso de licenciatura.

Um outro grupo de alunos ressaltou os sintomas gerados pela ansiedade como os principais dificultadores no processo da aprendizagem.

León (4o semestre): "Não tenha dúvida, quem tem ansiedade, por experiência própria, tem um certo grau de negatividade, como eu trabalhava muito fora e eu tinha que ajudar minha mãe em casa, tudo isso gerava um stress muito grande e eu ficava muito ansioso. Era muito ruim, suava frio, quando eu parava para estudar, achava que não ia conseguir, que não ia ser o suficiente e atrapalhava demais."

Diego (3o semestre): "Sim, porque é uma pressão muito forte e ter uma crise de ansiedade só piora tudo, deixa você desmotivado com tudo."

Franco (10 semestre): "Atrapalha, porque se a pessoa fica ansiosa demais, ela acaba se desconcentrando dos afazeres dela e repentinamente ela vai piorando."

Sobre essa realidade, Marchi et al. (2013) afirmam que apesar de os níveis moderados de ansiedade serem comuns à aprendizagem, níveis mais elevados atrapalham e nesse sentido, Oliveira et al. (2006) complementam que o alto nível de ansiedade interfere em alguns aspectos cognitivos do aluno, influenciando no processamento de informações na memória e levando a déficit no raciocínio. Logo, a partir das falas dos sujeitos pesquisados, é necessário que se reavalie situações geradoras de ansiedade dentro do curso, principalmente naquilo que surge pela ação negativa de professores, pois isso poderá produzir bem-estar e contribuir para melhorar a aprendizagem dos estudantes.

\section{CONSIDERAÇÕES FINAIS}

O estudo mostrou que existem alunos com diferentes perfis de ansiedade (desde o leve ao severo) dentro do curso de Ciências Biológicas da UECE, e, dentre as argumentações dos entrevistados, observou-se que a má relação professor/aluno foi o principal aspecto citado como complicador do processo de aprendizagem.

Dessa forma, faz-se necessário uma avaliação mais ampla desta temática, abordando mais estudantes e incluindo, também, o corpo docente, para que essa problemática seja melhor observada e discutida a fim de gerar um ambiente mais favorável ao processo de aprendizagem dentro do curso. 


\section{REFERÊNCIAS}

[1] Abrão, M. A Importância das Atividades Complementares na Formação dos Alunos da Graduação. Tese (doutorado) - Universidade Estadual de Campinas, Faculdade de Educação - Campinas, SP, 2015.

[2] Ackerman, D. S.; Gross, B. L. My Instructor Made Me Do It: Task Characteristics of Procrastination. Downloaded from: jmd.sagepub.com at California ST Univ Northridge on August 19, 2014.

[3] Almondes, K. M.; Araújo, J. F. Padrão do ciclo sono-vigília e sua relação com a ansiedade em estudantes universitários. Estudos de Psicologia 2003.

[4] Baptista, A.; Carvalho, M.; Lory, F. O Medo, a Ansiedade e as Suas Perturbações. Psicologia, XIX, 1/2, 266 $277,2005$.

[5] Bardagi, M. P., Hutz, C. S. Eventos estressores no contexto acadêmico: Uma breve revisão da literatura. Interação em Psicologia, 15(1), 111-119, 2011.

[6] Bardagi, M. P.; Hutz, C. S. "Não havia outra saída": percepções de alunos evadidos sobre o abandono do curso superior. Revista: Psico-USF, vol. 14, núm. 1, abril, 2009.

[7] Borralha, S. Ansiedade em Situações de Avaliação. Potal dos Psicólogos: psicologia, 2012.

[8] Brait, L. F. R.; Macedo, K. M. F.; Silva, F. B.; Silva, M. R.; Souza, A. L. R. A Relação Professor/Aluno no Processo de Ensino E Aprendizagem. Revista Eletrônica do Curso de Pedagogia do Campus Jataí - UFG, V.8 N.1. 2010.

[9] Brandtner, M.; Bardagi, M. Sintomatologia de Depressão e Ansiedade em Estudantes de uma Universidade Privada do Rio Grande do Sul. Revista Interinstitucional de Psicologia, Uberlândia-MG, 2009.

[10] Britto Júnior, A. F. B.; Feres Júnior, N. A utilização da técnica da entrevista em trabalhos científicos. Revista: Evidência, Araxá, v.7, n.7, p. 237-250, 2011.

[11] Carlotto, R. C.; Teixeira, M. A. P.; Dias, A. C. G. Adaptação Acadêmica e Coping em Estudantes Universitários. Psico-USF, Bragança Paulista, v. 20, n. 3, p. 421-432, set./dez. 2015.

[12] Carvalho, E. A.; Bertolini, S. M. M. G.; Milani, R. G.; Martins, M. C. Índice de Ansiedade em Universitários Ingressantes E Concluintes DE Uma Instituição de Ensino Superior. Revista:Ciência, Cuidado e Saúde. v.14, 2015.

[13] Castillo, A. R. G. L.; Recondo, R.; Asbahr, F. R.; Manfro, G. G. Transtornos de ansiedade. São Paulo:Revista Brasileira de Psiquiatria. v.22, 2000.

[14] Langame, A. P.; Neto, J. A. A.; Melo, L. N. B.; Castelano, M. L.; CUNHA, M.; Ferreira, R. E. Qualidade de Vida DO Estudante Universitário e 0 Rendimento Acadêmico. Rev Bras Promoç Saúde, Fortaleza, 29(3): 313-325, jul./set., 2016.

[15] Lantyer, A. S.; Varanda, C. C.; Souza, F. G.; Padovani, R. C.; Viana, M. B.

[16] Ansiedade e Qualidade de Vida entre Estudantes Universitários Ingressantes: Avaliação e Intervenção. Revista Brasileira de Terapia Comportamental e Cognitiva, Volume XVIII n.2, 4-9, 2016.

[17] Marchi, K. C.; Bárbaro, A. M.; Miasso, A. I.; Tirapelli, C. R. Ansiedade e consumo de ansiolíticos entre estudantes de enfermagem de uma universidade pública. Revista Eletrônica de Enfermagem, 2013.

[18] Medeiros, P. P.; Bittencourt, F. O. Fatores associados à Ansiedade em Estudantes de uma Faculdade Particular. Revista:Id on Line, Multidisciplinar e de Psicologia. V.10, N. 33, 2017.

[19] Monteiro, C. F. S.; Freitas, J. F. M.; Ribeiro, A. A. P. Estresse no Cotidiano Acadêmico: O Olhar dos Alunos de Enfermagem DA Universidade Federal do Piauí. Esc Anna Nery R Enferm, Piauí, 2007.

[20] Oliveira, C. T.; Carlotto, R. C.; Teixeira, M. A. P.; Dias, A. C. G. Oficinas de Gestão do Tempo com Estudantes Universitários. Psicologia: Ciência e Profissão, vol. 36, n.1, 224-233, 2016.

[21] Oliveira, K. L.; Santos, A. A. A.; Cruvinei, M.; Néri, A. L. Relação entre ansiedade, depressão e desesperança entre grupos de idosos. Revista: Psicologia em Estudo, Maringá, v.11, n.2, p. 351-359, mai/ago. 2006.

[22] Oliveira, M. A.; Duarte, A. M. M. Controle de Respostas de Ansiedade em Universitários em Situações de Exposições Orais. Revista Brasileira de Terapia Comportamental e Cognitiva. Vol. VI, n. 2. 2004.

[23] Ramos, A. M.; Barlem, J. G. T.; Lunardi, V. L.; Barlem, E. L. D.; Silveira, R. S.; Bordignon, S. S. Satisfação com A Experiência Acadêmica Entre Estudantes de Graduação em Enfermagem. Texto Contexto Enferm., Florianópolis, 2015.

[24] Sà, S. D.; Werlang, B. S. G.; Paranhos, M. S. Intervenção em crise. Revista Brasileira de Terapia Cognitiva, 2008.

[25] Sampaio, R. K. N. Procrastinação acadêmica e autorregulação da aprendizagem em estudantes universitários. Dissertação (Mestrado) - Universidade Estadual de Campinas, Faculdade de Educação - Campinas, SP, 2011.

[26] Santos, A. A. A.; Polydoro, S. A. J.; Scortegagna, S. A.; Linden, M. S. S. Integração ao ensino superior e satisfação acadêmica em universitários. Revista: Psicol. cienc. prof. [online, vol 33, n.4, pp 780-793, 2013. 
[27] Santos, R. M. Perfil de ansiedade em Estudantes Universitários de cursos da área da saúde. Dissertação (Mestrado em Saúde Pública) - Universidade Estadual da Paraíba, Pró-Reitoria de Pós-Graduação, 2014.

[28] Silveira, C.; Norton, A.; Brandão, I.; Torres, A.R. Saúde mental em estudantes universitários, Experiência da Consulta de Psiquiatria do Centro Hospitalar São João. Acta Med Port., n. 24(S2), 2011. 


\section{Capítulo 11}

Investigação da inclusão de Questões de Gênero na formação de Professores de Química

\section{Ana Patricia Farias Borges \\ Paulo Alves Xavier da Silva \\ Maria do Socorro Tavares Cavalcante}

Resumo: Este trabalho investiga o nível de conhecimento dos alunos do curso de Licenciatura em Química do Instituto Federal do Sertão Pernambucano, Campus Petrolina, acerca da diversidade de gênero, com o objetivo de contribuir para a inclusão de pessoas transgênero em polos sociais, como por exemplo a escola, porque embora a conquista por direitos LGBTI+ (lésbicas, gays, bissexuais, transgêneros e intersexo) tenha avançado em diversos países ao longo dos anos, pessoas transgênero continuam sendo invisibilizadas e sem acesso a direitos básicos assegurados a pessoas cisgênero inclusive no ambiente escolar. A pesquisa é quantitativa, pois foi estruturada para se obter dados numéricos. Iniciou-se com exploração da literatura científica sobre o tema e depois houve a exibição de um documentário para os licenciandos e a aplicação de um questionário. As atividades foram desenvolvidas em uma sala de aula do instituto, abordando especificamente alunos do primeiro período de licenciatura em química. Concluiu-se que, embora os participantes se interessem por compreender o tema, há poucas abordagens ao longo de sua formação que os façam desconstruir conceitos transfóbicos. Compromete-se a execução de uma educação que respeite todos os gêneros e garanta a inclusão da pessoa transgênero em sala de aula. Ressalta-se ainda que em alguns momentos da pesquisa, os alunos reproduzem também conceitos errôneos e ligados ao senso comum, o que revela a necessidade de uma atenção da comunidade científica a respeito da inserção de aluno transgênero em espaços sociais e, sobretudo, no ambiente escolar.

Palavras-chave: Ensino inclusivo, inserção social, educação, transgeneridade, diversidade de gênero. 


\section{INTRODUÇÃO}

O conceito de gênero que se conhece hoje, visto como uma ferramenta política, foi criado para que houvesse uma distinção entre gênero e sexo, sendo sexo visto como a genitália de cada pessoa e gênero uma identidade cultural que rejeita o determinismo biológico (LOURO, 1997). A criação do conceito de gênero é recente se comparado ao conceito de identidade, por isso ainda existe o pouco conhecimento de como esses dois se relacionam e as diferentes nuances existentes.

Segundo Vasconcelos (2018), mesmo que o debate sobre diversidade sexual e de gênero tenha aumentado ao longo dos anos, o número de casos de evasão devido a transfobia também aumenta, cabe ao professor a mobilização em sala de aula para que a transfobia deixe de acontecer e essa base de conhecimento deve ser adquirida durante a sua formação, pois a pouca difusão de informações acerca desse tema faz com que pessoas transgênero continuem sendo colocadas à margem da sociedade e tenham pouco acesso ao ambiente escolar.

Esse trabalho tem como objetivo então conceituar os níveis de conhecimento dos alunos de Licenciatura em Química do IF-Sertão acerca da diversidade de gênero. Para isso foi apresentado um documentário que aborda gênero e trangeneridadade e em seguida houve a aplicação de um questionário adaptado, que foi analisado de forma qualitativa a partir das informações apresentadas no referencial teórico.

Os resultados mostram que os alunos vêem a importância da inclusão do debate sobre gênero e pessoas transgênero em sala de aula, assim como também da realização de projetos dentro da escola que envolvam os alunos com o tema. Porém tais alunos não esperam, durante a sua formação, que hajam momentos no curso de licenciatura destinados ao debate e aprofundamento de tais temas. Foi observado também que muitos dos conhecimentos apontados pelo alunos questionados são conhecimentos de senso comum e muitas vezes com teor transfóbico, mostrando mais uma vez a necessidade do abordagem do tema durante a sua formação, para que tais ideias não sejam passada para o futuros alunos, contribuindo mais para a transfobia em sala de aula.

Mostra-se fundamental, então, a preocupação da instituição acerca do debate de gênero e transgeneridade com os alunos que estudam, pois há o interesse destes para aprender mais sobre o tema e passar tais informações adiante de forma correta, para que os futuros alunos também possam contribuir para um ambiente seguro em sala de aula para alunos de todos os gêneros.

\section{METODOLOGIA}

Este estudo consiste de uma análise quantitativa para obter dados que expressassem o conhecimento de diversidade de gênero pelos licenciandos de química do IF Sertão - PE, campus Petrolina, pois como relata Walner (2017) a ideia da pesquisa correlacional é verificar a existência de alguma relação estatística entre poucas variáveis em um grande conjunto de dados. No caso mais comum, busca-se uma correlação significativa entre duas variáveis. Com isso, a pesquisa se iniciou com leitura exploratória de artigos encontrados nas plataformas do Scientific Electronic Library Online (SCIELLO) e Google Acadêmico, em seguida, foi elaborado um questionário de caráter quantitativo e com respostas fechadas e objetivas que buscou desvendar o nível de conhecimento dos licenciandos com a finalidade de se obter as estatísticas e quantificar as respostas, entretanto, questões com muitas opções de respostas ou que cujas alternativas poderiam influenciar na respostas foram colocadas de maneira abertas, porém os dados também foram analisados de maneira qualitativa.

Dessa forma o questionário foi aplicado com alunos do primeiro período do curso Licenciatura em Química da instituição, turma ingressante em 2019.1, com faixa etária entre 18 e 22 anos, sendo uma turma mista (composta por homens e mulheres). Ao todo foram abordados para esse estudo 8 alunos. Foi exposto a turma a proposta da pesquisa, logo em seguida disponibilizou-se horários em que os alunos puderam escolher de acordo com a sua disponibilidade e agendar para responder as perguntas. Vale destacar que alguns alunos optaram por não participar da pesquisa, em sua maioria por falta de tempo.

Antes da aplicação do questionário, no entanto, houve a exposição de um documentário por Santos (2016) acerca da realidade de quem vivencia um gênero que não se encaixa na cisgeneridade. Reservou-se uma sala específica para execução, assim os alunos tiveram acesso a uma sala com computadores, onde foi exibido um documentário intitulado de 
"Transgênero", com duração de 16 minutos e 27 segundos, os participantes foram instruídos a levar canetas e fones de ouvidos, para responder o questionário e ter acesso ao vídeo. Os horários foram articulados para que os licenciandos não se encontrassem em nenhuma atividade acadêmica, a fim de não comprometer outros afazeres e nem influenciar na atenção dada ao tema. Com o as questões abordadas pelo documentário promoveram-se uma reflexão e disponibilizou informações necessárias para os licenciandos lidarem de forma adequada com a diversidade de gênero não apenas em sala de aula, mas também exercendo cidadania e respeito em todos os ambientes, além de efetivar propriedades para se responder o questionário aplicado logo em seguida.

Com o questionário iniciou-se com uma abordagem direta sobre o conhecimento de identidade de gênero dos entrevistados e trouxe questões de designação correta dos termos de gênero além de aspectos da transfobia, o participante tem duas opções de resposta que na maioria das perguntas versa entre negativo e positivo, para algumas questões foi disponibilizado um espaço para o aluno dissertar sobre seu ponto de vista como já foi pontuado, além de conter algumas perguntas com cinco respostas, onde o participante escolhia apenas uma. 0 questionário utilizado foi adaptado de Rizzato (2013), pois a pesquisadora dá ênfase nos aspectos da pluralidade sexual dos indivíduos, enquanto que para esse estudo propõe-se apenas uma reflexão acerca da diversidade de gênero.

\section{DESENVOLVIMENTO}

O conceito de gênero tem um forte vínculo e abertura com o movimento feminista contemporâneo, se faz fragmento do movimento e é expressado através dos discursos políticos e de suas lutas. Deste modo, na consolidação da "segunda onda" do feminismo, onde o movimento propõe uma reflexão sobre posicionamentos sociais enraizados na sociedade, surge a preocupação e o debate sobre o conceito de gênero. (LOURO, 1997).

A sociedade designa de forma arbitrária o gênero das pessoas no nascimento ou até mesmo antes disso, com o avanço da ultrassonografia, de acordo com qual genital cada pessoa possui. A partir disso o gênero é construído culturalmente ao longo da vida e pode ser desconstruído subjetivamente, onde pessoas designadas homem ao nascer aprendem que devem possuir um comportamento "masculino" e pessoas designadas mulheres ao nascer devem possuir um comportamento "feminino". Essas influências sociais não são claramente visíveis e por isso comumente justificam-se esses comportamentos com fatores biológicos inerentes do ser humano. Porém, mesmo o que é considerado masculino e feminino é inconstante e depende da cultura do local onde a pessoa nasceu, características consideradas masculinas em um país ou grupo étnico podem ser consideradas femininas em outro. (JESUS, 2012).

Deve-se ressaltar que sexo, como sinônimo de genitais, é biológico, gênero é social e independente do conceito de sexo, ou seja, é construído pelas diferentes culturas e tempos históricos. Gênero se simplifica pela autopercepção a partir de seu corpo e a maneira como o indivíduo se expressa e se insere na sociedade, não tendo necessariamente um vínculo com quais cromossomos sexuais que esse ser produz. Um ponto bastante fundamental é a diferença entre sexualidade e identidade de gênero, pois é errôneo definir um pelo outro. Orientação sexual se refere à atração sexual por um ou mais gêneros. Com isso, uma pessoa transgênero pode ser bissexual, heterossexual ou homossexual, dependendo do gênero que adota e do gênero com relação ao qual se atrai sexualmente. É, portanto, errado pensar que todas as pessoas transgênero são homossexuais, embora pertençam ao mesmo grupo político, o de Lésbicas, Gays, Bissexuais, Transgêneros - LGBT+. A homossexualidade é o ato de se atrair pelo mesmo gênero enquanto que a bissexualidade é o ato de se atrair por pessoas de qualquer gênero, o que não se relaciona com sua identidade de gênero. (JESUS, 2012).

Para se entender com clareza o que significa de fato ser uma pessoa transgênero, é importante entender que, de forma bem simplificada, todos diversos gêneros podem ser enquadrados entre cisgênero e transgênero. Jesus (2012) aponta que a cisgeneridade é a condição de se identificar com o gênero que lhe foi designado desde o nascimento, se fundamentando sobretudo no genital, por outro lado, há uma certa parcela da sociedade que não é assim, pois gênero, por ser uma construção cultural, é algo que tem a capacidade de transcender os padrões biológicos simplórios adotados para reconhecer um gênero. Dessa forma, surge a pessoa "trans", ou pessoa transgênero, que são não-cisgênero, ou seja, não se identificam com o gênero que lhes foi determinado ao nascer. 
Um bom exemplo disso são as travestis, e das transexuais, que são tratadas, coletivamente, como membro do grupo de pessoas transgênero, sendo travesti uma denominação exclusiva da América Latina para pessoas com uma identidade de gênero feminina que foram designadas homem ao nascer.

A não-binariedade é não ser parte de especificamente um dos gêneros binários, portanto uma pessoa não binária pode ser de alguns dos gêneros, mas não totalmente, sendo um homem não-binário ou mulher não-binária, assim como pode não ser parte de nenhum dos gêneros, como uma pessoa agênero, ou ser dos dois gêneros, como uma pessoa bigênero. 0 termo "não-binário" é um termo guarda-chuva, ou seja, engloba diversas identidades de gênero que fogem ao binarismo homem/mulher.

Como mostra Becattini (2017) embora haja na sociedade atualmente uma ideia binária de gênero, existem diversas culturas ao redor do mundo que reconhecem mais de dois gêneros, como os Quariwarmi, pessoas no Império Inca cujo gênero abrangia o masculino e o feminino. Os Bugi, grupo étnico da Indonésia, reconhecem cinco gêneros, sendo um deles, Bissu, definido como a união do masculino e do feminino, se assemelhando à não-binariedade.

Junqueira (2010) aponta a necessidade da escola de ser um ambiente livre de preconceitos e que elimina quaisquer hierarquias opressivas, pois o ambiente escolar deve ser um espaço seguro e responsável por uma formação para a vida. A escola, no entanto, geralmente falha nesse deve e se torna responsável pela criação de um ambiente rodeado de preconceitos criados a partir de discursos heteronormativos e da transmissão de normas de gênero, ou seja, que enfatizam a heterossexualidade como única orientação sexual possível e o gênero determinado ao nascimento como o único gênero possível, tais comportamentos se apresentam em diversas áreas do âmbito escolar.

Em contra partida às formas de LGBTfobia na escola feitas a partir de violência verbal e física, há também o preconceito partindo do silenciamento: Alunos com identidades de gênero e orientações sexuais que diferem do padrão heterossexual e cisgênero se sentem forçados a não comentar sobre o assunto com as pessoas ao seu redor, para evitar sofrer preconceito direto, porém o silenciamento também é uma forma de violência contra esses alunos. (DINIS, 2011). desenvolvimento da pesquisa contém a síntese bibliográfica, principais discussões teóricas e a trajetória da mesma ao longo do recorte estudado.

\section{RESULTADOS E DISCUSSÃO}

Quando perguntados se, durante a formação, em algum momento eles haviam sido orientados a lidar com questões relativas à pessoas transgênero, transexuais ou travestis, todos os participantes responderam que não. Esse fato pode ser explicado, principalmente, considerando que o questionário foi aplicado com alunos do primeiro semestre do curso, que haviam ingressado há poucos meses no instituto, entretanto, com a realização da pesquisa já próxima ao fim desse semestre, é possível perceber também que não houve, nessa introdução do aluno ao curso, nenhum momento específico voltado para o debate sobre questões voltadas para gênero e transgeneridade, mesmo que se note que há, ao longo do curso e desde o seu princípio, a busca por debates em sala de aula a respeito de temas que contribuam para a formação de professores com preparo e olhar crítico para diversas questões relacionadas à inclusão em sala de aula.

Entretanto, numa questão aberta relacionada à pergunta anterior, quando perguntados se, caso houvessem tido esse contato durante a formação, como ele havia ocorrido, alguns alunos, mesmo respondendo não ter tal contato no curso, complementaram falando que esse contato havia ocorrido em outros momentos da vida, como a partir de pesquisas e conversas com pessoas transgênero e a partir de uma criação onde os pais afirmaram a importância de tratar bem cada pessoa independente de sua orientação de gênero. Vê-se então que, mesmo com a ausência de contato com tais questões no início do curso, os alunos conseguem encontrar outras formas de entender sobre o assunto, porém fora do ambiente de sala de aula voltado para sua formação enquanto professores, os alunos acabam então buscando conhecimentos sobre tais assuntos sem relacioná-los diretamente ao ambiente escolar e sem imaginar como usá-los no futuro para instruir seus alunos a respeito de questões relacionadas a gênero de uma forma livre de preconceitos.

$\mathrm{Na}$ questão seguinte, quando questionados se esperavam ser orientados ao longo do curso sobre tais questões, alguns alunos responderam que $\operatorname{sim}(37,5 \%)$, mas a maioria $(62,5 \%)$ continuou acreditando que não haveria essa orientação a respeito de pessoas transgênero, transexuais e travestis ao longo do curso. 
Essa falta de instrução por parte dos professores pode levar ao que Dinis (2011) destaca como preconceito em forma de silenciamento: o aluno que experiência uma identidade de gênero fora do padrão cisgênero não consegue encontrar em sala de aula um reforço positivo que incentive a sua descoberta e/ou aceitação, pois o professor, por não se sentir apto a abordar tais assuntos, acaba impedindo esse diálogo em sala de aula e prejudicando ambas as partes: dos alunos cisgênero que poderia ser aliados na causa transgênero e dos alunos transgênero que não terão a oportunidade de se sentir tão confortáveis com sua identidade de gênero quanto poderiam.

A maioria dos alunos $(87,5 \%)$ demonstraram esperar lidar com questões relacionadas a gênero e/ou transgeneridade/transexualidade em sala de aula, enquanto apenas 12,5\% demonstram não esperar, segundo Vasconcelos (2018) o debate sobre tais temas vem aumentando em sala de aula ao longo dos anos porém ainda existe o aumento da transfobia em sala que pode levar à evasão de alunos transgênero, o papel do professor, nesse sentido, é despertar em sala de aula a empatia dos alunos para que haja o melhor convívio em sala com as diferenças de gênero, dentre os entrevistados é possível ver que se espera que tais temas sejam abordados em sala, porém com a falta de preparo ao longo do curso a abordagem desse tema pode ser levada para um caminho rodeado de preconceitos, que não era o que o professor esperava inicialmente.

Essa falta de preparo é apontada nas perguntas seguintes quando, perguntados qual resposta daria numa situação que levasse o aluno a perguntar "professor(a), transgênero, afinal, o que é?", maioria (62,5\%) marcou que é uma questão de opção, uma escolha como qualquer outra, mostrando que ainda veem a transgeneridade como algo que é escolhido, e o normal é ser cisgênero, e quando pedido para descrever o que é transgeneridade/transexualidade, mesmo que a alternativa mais escolhida (37,5\%) foi a que a define como genética, alguns dos entrevistados (25\%) marcaram que é uma escolha, e a pessoa opta por ser transgênero, transexual ou travesti e 12,5\% que escolheram dar outra resposta por escrito também comentaram que seria uma escolha, entretanto, segundo Jesus (2012), gênero e padrões de gênero são construções culturais e a quebra desses padrões ocorre de maneira natural, pois nem todas as pessoas se sentem confortáveis com algo imposto a elas.

Com relação ao envolvimento direto da escola com o tema, não somente da abordagem em sala de aula, os entrevistados se mostraram bastante favoráveis, ao serem questionados se acreditavam que a escola deve realizar trabalhos relacionados ao tema, nenhum deles se mostrou diretamente contra isso: 87,5\% dos alunos responderam achar a realização desses trabalhos necessária e 12,5\% se mostraram em dúvida e não souberam responder, os alunos que se mostraram a favor foram instigados a dar sua justificativa para isso e, dentre as justificativas, foi apontado a importância do combate ao preconceito a partir de tais trabalhos a partir da quebra de tabus, além de reforçar o respeito por pessoas que fogem da cisgeneridade atrás do maior conhecimento de suas vivências e causas, para que, com a desmistificação do assunto na escola, os alunos transgênero se sintam mais livres para se expressarem da maneira que se sentirem melhores.

Os entrevistados também, em sua maioria (75\%) se mostraram dispostos a participar de um trabalho como este, enquanto apenas $25 \%$ não soube responder e nenhum se mostrou completamente indisposto a participar, é possível perceber, então, que mesmo com a pouca abordagem do tema no curso, os alunos ainda sentem vontade de compreender sobre o assunto e de se responsabilizarem por passar informações adiante para seus futuros alunos e ajudar no combate ao preconceito.

No final do questionário os entrevistados tiveram a liberdade de acrescentar qualquer comentário sobre o tema que achassem importante, os comentários feitos reforçam as opiniões a respeito do tema e sobre a importância do combate ao preconceito, as falas feitas comentam, por exemplo, sobre o direito que as pessoas possuem de se sentir bem do jeito que são, independente dos comentários de outras pessoas que podem vir acompanhados de preconceitos, com relação ao preconceito também foi comentado a importância da abordagem do tema em sala de aula pois, mesmo que o mundo tenha avançado e continue avançando, o preconceito ainda é um problema presente na sociedade e que precisa ser combatido, pois a falta de informação pode levar ao aumento desse preconceito. 


\section{CONSIDERAÇÕES FINAIS}

Conclui-se que embora haja o grande interesse dos alunos em relação ao tema, tais alunos possuem pouca esperança de participarem de aulas inclusivas com foco em gênero e transgeneridade. É possível perceber também que tais alunos esperam, enquanto professores, serem resposáveis por instruir seus futuros alunos e levá-los a ter uma visão livre de preconceitos a respeito de pessoas transgênero, porém, sem o debate correto a respeito do tema pode haver, pelo contrário,a transmissão de conceitos tranfóbicos em sala de aula que levam à um ciclo de preconceitos. Há a necessidade então de maior debate sobre o tema durante a formação e maiores pesquisas na área científica que abracem a vivência de pessoas transgênero nos diferentes níveis de educação, como forma de contribuir para o aumento de sua inclusão e a diminuição do preconceito no ambiente escolar.

\section{REFERÊNCIAS}

[1] Becattini, Natália. 7 culturas com identidades de gênero não-binárias. 360meridianos. Disponível em: <https://www.360meridianos.com/especial/culturas-identidades-de-genero-nao-binarias >. Acesso em: 30 de maio de 2018.

[2] Dinis, Nilson Fernandes. Homofobia e educação: quando a omissão também é signo de violência. Educar em Revista, [S.l.], v. 27, n. 39, p. p. 39-50, abr. 2011. ISSN 1984-0411. Disponível em: <https://revistas.ufpr.br/educar/article/view/21410>. Acesso em: 27 mai. 2019.

[3] Jesus, Jaqueline Gomes de. Orientações sobre identidade de gênero: conceitos e termos. 2. ed. Brasília: [s.n.]., 2012.

[4] Junqueira, Rogério Diniz. Currículo heteronormativo e cotidiano escolar homofóbico. Revista Espaço do Currículo, v. 2, n. 2, 2010.

[5] Louro, Guacira Lopes. Gênero, sexualidade e educação. Petrópolis: Vozes, 1997.

[6] Rizzato, Liane Kelen. Percepções de professores/as sobre gênero, sexualidade e homofobia: pensando a formação continuada a partir de relatos da prática docente. 2013. Dissertação (Mestrado em Educação) - Faculdade de Educação, Universidade de São Paulo, São Paulo, 2013. Doi: 10.11606/D.48.2013.tde-23102013-112910. Acesso em: 2019-05-30.

[7] Santos, Natalia D. Transgênero - $\quad$ Documentário. 2016. Disponível em: < https://www.youtube.com/watch?v=NA4BweFbpys>. Acesso em: 25 de maio de 2019.

[8] Vasconcelos. Fábio Roberto da Silva. Evasão escolar de alunas travestis e transexuais. FURG, 2018. Disponível em: <https://7seminario.furg.br/images/arquivo/250.pdf>. Acesso em: 25 de maio de 2018.

[9] Wainer, Jacques et al. Métodos de pesquisa quantitativa e qualitativa para a Ciência da Computação. Atualização em informática, v. 1, p. 221-262, 2007. 


\section{Capítulo 12}

Pensamento e ação do corpo na educação e formação de professores

\section{Alice Maria Corrêa Medina}

Resumo: 0 presente trabalho foi configurado como uma atividade de extensão e pesquisa oferecida pela Faculdade de Educação da Universidade de Brasília - UnB. Foram desenvolvidas oficinas e construções corporais com estudantes da universidade. Participaram das atividades de extensão estudantes da disciplina de Psicologia Social na Educação, ofertada pela Faculdade de Educação na UnB. 0 estudo teve como objetivo desenvolver atividades relacionadas à consciência corporal, ao movimento expressivo para a construção do conhecimento e apropriação de si, além de trabalhos interdisciplinares baseados nos conteúdos de livros didáticos do ensino fundamental. A metodologia utilizada seguiu uma orientação transdisciplinar, por meio de oficinas e a construção de textos escritos e movimentos corporais. Dentre as atividades realizadas, a pesquisa e a seleção de conteúdos didáticos integraram os trabalhos, sendo selecionados, discutidos e apresentados corporalmente em função do interesse dos participantes. Foram utilizadas várias dinâmicas integrativas, assim como a pesquisa e a seleção de temas contextuais para representações corporais. Os conteúdos utilizados para as atividades interdisciplinares foram baseados em livros didáticos de Ciências e História. A coleta de dados foi realizada por meio de registros dos relatos dos participantes e na observação durante a execução do trabalho. 0 presente estudo pelas produções e dados obtidos permitiu a conclusão de que o conhecimento do corpo é fundamental para o desenvolvimento de uma consciência e ação cidadã, corroborando para um entendimento de que a identidade e a subjetividade, assim como o físico e a racionalidade, são elementos estruturantes de um mesmo indivíduo na sua dimensão de complexidade. A subjetividade está inCORPORADA ao movimento e é de suma importância sua relação com a educação.

Palavras-Chave: Corpo. Movimento. Educação. 


\section{INTRODUÇÃO}

A construção de toda a relação e construção do conhecimento se dá por meio de processos de interação de elementos sinérgicos materiais e imateriais que integram o corpo e a vida. A palavra sinergia deriva do grego synergia, relacionada a cooperação. Sinergias são energias que atuam de forma coordenada para a realização de uma tarefa, com um mesmo objetivo. Quando as bases corporais integradas pelas emoções, relações afetivas, massa corpórea entre outras, interagem de maneira harmônica, surge uma base edificada e sustentada que legitima a arquitetura e identidade do Ser.

Ciência e existência caminham juntas e a construção continuada do pensamento científico encontra-se ligada ao saber da própria humanidade. Concomitantemente ao nascimento da modernidade, surge um individualismo extremo que leva muitas vezes a uma desconsideração sobre a própria condição humana.

Segundo Morin (2000), o conhecimento não se encontra apenas no objeto de estudo, mas é construído de forma interativa pelo homem, fundamentando a noção de interação no processo de construção. 0 homem é constituído por um corpo integrado por uma massa corporal, cognição, emoção e subjetividade, entre outras áreas e aspectos que integram esse ser complexo.

A noção de corporalidade é fundamental para compreender o pulsar da vida humana, a energética do Ser. O corpo é a legitimação espaço-temporal do Ser no mundo. A corporalidade ou corporeidade refere-se ao campo existencial das vivências de acordo com Cavalcanti (2004).

A cultura e o biológico estão ligados. A cultura é a ação integradora das estruturas físicas, cognitivas e emocionais, seja a nível micro e macro do indivíduo. Entendida como a representação física, social, intelectual e emocional a partir das relações do indivíduo com ele próprio e com o seu contexto, a cultura legitima cada indivíduo em sua origem e identidade.

Atualmente há uma sensibilização interplanetária para que o homem reconheça e efetivamente assuma suas responsabilidades sociais, humanas e com o planeta. A unidade como espécie, não deve descaracterizar a singularidade e a complexidade humana no mundo, sendo essas orientadas em prol de uma consciência e atitude para a vida.

Um projeto discutido no Congresso Internacional "Que Universidade para o amanhã? Em busca de uma evolução transdisciplinar da universidade" (1997) elaborado pelo Centro Internacional de Pesquisas e Estudos Transdisciplinares - CIRET-UNESCO apresentou como objetivo propiciar a evolução universitária considerando-se todos os componentes de complexidade que envolve a vida.

Dentre os assuntos abordados pelo documento, a quantidade e a diversidade dos saberes são relacionadas como bens que a humanidade se apropriou ao longo do tempo, considerando que os mesmos devem coexistir diante de um sujeito-conhecedor integrante da natureza e do conhecimento dialógico que é capaz de construir.

Os indivíduos estão inseridos em contextos diversificados e possuem um saber tácito pessoal, social e cultural sendo capazes de construir algo positivo diante de uma sociedade complexa e em prol de um conhecimento edificado de forma sustentável, favorecendo de maneira efetiva a educação para a vida por meio de processos educativos mais amplos e contextualizados.

A Teoria de Autopoiese de Maturana e Varela (1997) sobre a autoprodução e auto-organização corroborou com o estudo, já que os participantes tiveram como ponto de partida temas e conteúdos dinâmicos, para compor sua representação corporal com a inserção do componente cultural e subjetivo nas linguagens corporais, sensórias e expressivas.

O presente artigo originou-se de um projeto de extensão e pesquisa que teve por finalidade desenvolver atividades e trabalhos de extensão e pesquisa baseados em ações e expressão transdisciplinares na construção das relações entre os diversos tipos de saberes.

\section{0 CORPO}

A construção do conhecimento efetiva-se pela intervenção e interação ativa no processo dialógico entre as informações. Ao proporcionar-se um ambiente no qual exista a requisição do corpo, da mente e da emoção unidos, o todo será solicitado e ativado ocorrendo uma elaboração sedimentada e ampliada.

Nas inter-relações entre os indivíduos e os grupos em ambientes de trocas dinamizadas, os resultados ou respostas que surgem como representação desses, poderá apresentar características parecidas ou próximas aos referenciais de origem, ou de outra forma, constituírem-se de uma identidade totalmente 
nova e mesclada pela participação expressiva de cada novo elemento. Os fluxos de energia ultrapassam os contornos corporais, pois o corpo ativo e/ou passivo poderá assumir posições diferenciadas no campo das trocas e interferências com aquilo que os cerca e com o circulante em seus respectivos campos de energia.

Os movimentos realizados pelos músculos que sustentam e carregam, têm origem nos movimentos pensantes e decisórios sobre a ação e reação, determinando como, por que e o que será necessário mobilizar para a ação.

Segundo Merleau Ponty (1999) a percepção emerge da motricidade e a corporeidade define-se como unidade mente-corpo em movimento e instância privilegiada da percepção, sendo caracterizada como uma unidade perceptiva para a leitura do mundo.

\section{A COMPLEXIDADE HUMANA E AS DEMANDAS SOCIAIS}

o Complexus pode ser entendido, entre outros aspectos, como aquilo que é tecido junto no contexto da diversidade, ou seja, quando diferentes elementos articulam saberes e práticas para construírem o todo, configurando-se segundo Morin (2000), por meio das relações de interatividade entre o objeto de conhecimento e seu contexto.

Pensar a promoção dos seres humanos é também buscar compreender o complexo e sobre aquilo que é imprescindível ao equilíbrio, a harmonia e a saúde do todo.

0 paradigma relacionado à complexidade humana surge como uma necessidade da própria humanidade com suas singularidades, subjetividades e diferenças diante de um modelo até então promotor de emudecimento e fragmentação.

Entre as demandas vividas na contemporaneidade a relação com a natureza, assim como com tudo aquilo que se refere às questões ambientais, são temas que devem ser discutidos na pauta sobre a complexidade humana, principalmente aquelas relacionadas ao legado do processo civilizatório. A humanidade tem sua origem e destino na natureza e não pode ser pensada fora dela, reconhecendo o homem social inserido e integrado em um ambiente com duplo sentido diante das causas e resultados das várias ações no mundo.

As organizações sociais e hierarquizadas configuradas como de baixa complexidade determinando uma relação de dominação e subordinação segundo Morin (2007), por não contar com uma atmosfera favorável à diversidade das estruturas sociais complexas, comprometem seu desenvolvimento e autonomia entre suas redes e elementos integradores para que não ocorra uma segregação e emudecimento da vida.

A capacidade humana de inteligibilidade permite ao homem apropriar-se de teorias que efetivamente promovam o pensar reflexivo, interligando informações de maneira transdisciplinar com a construção continuada do pensamento científico, complexo e humano em prol de um sujeito que é ao mesmo tempo produtor e produto de um conhecimento relacional e integrado.

Segundo Morin (2004) apud Moraes (2008) a organização do conhecimento comporta separação e ligação, análise e síntese de tudo ao mesmo tempo, pois o processo de desconstrução e reconstrução é circular, dinâmico e recursivo em um vai e vem. Dessa forma, todo pensamento complexo se cria e se recria a partir do seu próprio movimento e a cultura é o meio na e pela qual todas essas ações e reações se manifestam.

As atividades corporais são ações que podem mobilizar dispositivos motivacionais com a valorização e inserção de experiências, sendo necessários para tais ambientes alegres e diversificados com estímulos variados, segundo Medina (2009).

O desenho ou a representação imaterial do conhecimento, caracterizado como resultado fluído das interrelações internas e externas do homem tem sua gênese nas dinâmicas estabelecidas entre os substratos e elementos que dinamicamente incorporam e excluem dados e informações do ambiente.

As áreas do conhecimento até então separadas, necessitam de um processo transdisciplinar de apropriação pela identidade integral do homem no seu universo. 0 paradigma da transdiciplinaridade está sustentado, entre outras bases, no reconhecimento e na ação direcionada para o diálogo entre as diferentes áreas na composição do todo. 0 homem racional também é emocional, físico, afetivo e cultural.

Tomando como exemplo, a partir do que foi discutido no parágrafo anterior, no contexto escolar há especificidades relacionadas às diferentes disciplinas que compõem o currículo, e que a partir de ações dialógicas contribuem para a construção do todo, ou seja, do conhecimento. Para que efetivamente se dê como transdisciplinar deverá ser incorporado ao conhecimento os referenciais dos agentes que 
participam desse processo com seus saberes e fazeres representados e legitimados no cotidiano. 0 conhecimento integral é transdisciplinar e significativo para quem os constrói.

\section{CORPO E CULTURA: CONDICIONANTES E CONDICIONADORES}

A cultura que constitui o corpo integral de cada indivíduo influencia diretamente na objetividade e subjetividade do tecido humano, e que por meio de teias relacionais estruturam e edificam toda a arquitetura social. 0 corpo integral tem sua inscrição na sociedade baseada na cultura, na história e nos saberes de cada indivíduo por meio do olhar e ação no mundo. Da mesma maneira, a cultura também é influenciada pelo homem no tempo e espaço vividos, sendo transformada ao longo do processo de busca e relação com o conhecimento.

À medida que a cultura imprime seu simbolismo no indivíduo também tem a impressão em si, do simbolismo e características daqueles que a constituiu. Segundo Morin, (2000 p.52) "o humano é um ser a um só tempo plenamente biológico e plenamente cultural, que traz em si a unidualidade originária".

A Cultura Corporal não está relacionada apenas aos sentidos e significados esculpidos nos corpos, mas constitui interfaces com o comportamento, as atitudes e emoções, sendo expressa pela maneira com que o homem vive e relaciona-se com o mundo. Estudos sobre a inteligência apontam que as rotinas e repetições paralisam o pensamento e que para que se desenvolva são necessárias situações desafiadoras e diversificadas, pois é alimentada pelos desafios encontrados em situações novas favorecendo novas formas de pensar e agir diante do inesperado. Cada indivíduo é produto e produtor de sua cultura retratando marcas culturais interiorizadas e exteriorizadas por suas ações ao longo da vida.

As referências contextuais são fundamentais favorecendo o processo de construção identitária para viver no mundo. As orientações curriculares devem ser fundamentadas na vida, no cotidiano conjuntamente com os desafios que os diferentes ambientes proporcionam. Não há receitas, há reflexão para ação, há habilidades desenvolvidas para adquirir competências na solução de novos problemas que surgem pela dinâmica da vida.

A influência cultural em cada indivíduo, relacionada ao grupo social o qual pertence, confere uma legitimidade dos valores e verdades difundidos e creditados como forma de identidade e de pertencimento a um determinado grupo. A cultura em sua inserção social é dotada de uma representação física, social, intelectual e emocional a partir das relações do indivíduo com ele próprio e com o seu contexto. $\mathrm{O}$ homem inserido no grupo pode viver, por meio de suas referências e pela forma de se relacionar e lidar com a vida, tudo aquilo que o caracteriza e lhe dá sentido e significado.

A diversidade cultural surge de um sentimento de diálogo para uma ação relacional, caracterizada pelas diferenças pessoais e sociais de um projeto humano diante da complexidade e singularidade.

A construção do conhecimento só acontece quando há intervenção e interação no processo de quem recebe a informação. Ao propiciar-se um ambiente no qual exista a requisição do corpo, da mente e da emoção unidos, o todo será solicitado e ativado, havendo uma construção mais forte e ampliada e não de forma segmentada, quando há uma solicitação de apenas uma das áreas.

O conhecimento não se encontra apenas no objeto de estudo, mas é construído de forma interativa pelo homem, constituído por um corpo integrado representado por uma massa corporal, por uma área cognitiva, emocional e subjetiva configurando-se em um ser humano único e complexo.

0 indivíduo age no mundo por meio do seu corpo e do seu movimento. A expressão corporal possibilita a comunicação entre as pessoas que podem trabalhar, aprender, sentir e serem sentidas de acordo com Strazzacapa (2001a):

Toda educação é educação do corpo. A ausência de uma atividade corporal também é uma forma de educação: a educação para o não movimento educação para a repressão. Em ambas as situações, a educação do corpo está acontecendo. 0 que diferencia uma atitude da outra é o tipo de indivíduo que estaremos formando. Cabe agora a cada um de nós fazer a reflexão. (STRAZZACAPPA, 2001b, p. 79). 
A noção de corporalidade é fundamental para compreender-se a vida, que é edificada no homem em campos de energias internas e externas que circulam entre e por meio do corpo integral, ou seja, físico, emocional, intelectual e cultural, sendo ao mesmo tempo origem e destino da própria vida. Segundo Varela; Thompson; Rosch (2001):

A cultura científica ocidental requer que tornemos nossos corpos simultaneamente como estruturas físicas e como estruturas experienciais vividas - em suma, tanto como externos e como internos, biológicos e fenomenológicos. (VARELA; THOMPSON; ROSCH, 2001, p.16)

É necessário perceber e entender o corpo como uma representação do ser com capacidade de comunicação e expressão, carregado de sentimentos, afetos e buscas, muitas vezes contidas, reconhecendo o homem com razão, emoção e imaginação. 0 corpo na educação em alguns casos tornou-se estilizado, com uma linguagem modelada, normatizada, destinada a primazia do verbal, da escrita e da gestualidade socializada, emudecendo, no entanto, os ritmos naturais e internos neutralizando desta forma o acesso às infinitas possibilidades de construção segundo Schwart (1997).

O antropólogo Mauss (2003) em estudos sobre as técnicas corporais reconhece o homem como um ser humano, biológico, psicológico e social desqualificando a concepção reducionista de um corpo que embora não instrumental, seja constantemente instrumentalizado. Da mesma forma Suassuna et. al. (2005) ressaltam sobre o valor de estudos que contemplem a concepção de corpo maneira integral:

Ao longo da discussão acumulada sobre o assunto, percebeu-se que uma definição meramente biológica, que considere a dimensão humana sobre apenas um aspecto não pode servir como referência para os estudos sobre o corpo que envolva o indivíduo de modo integral. (SUASSUNA et al., 2005, p. 31).

O corpo expressa elementos específicos da sociedade na qual está integrado com o qual vai assimilando e se apropriando de normas, costumes, atitudes e valores, num processo de incorporação. É um conteúdo cultural, que se instala e se manifesta em um corpo dialógico que representa o próprio indivíduo. Segundo Merleau Ponty (1999) a percepção emerge da motricidade e a corporeidade define-se como unidade mente-corpo em movimento e instância privilegiada da percepção, sendo uma unidade perceptiva para a leitura do mundo.

A proposta baseou-se no reconhecimento de que o corpo é a legitimação espaço-temporal do homem no mundo e que os processos de aprendizagens, são desenvolvidos por conexões dinâmicas de trocas entre estruturas internas e externas ao indivíduo, que tem sua representação no corpo e no movimento humano.

0 estudo teve como objetivo desenvolver atividades e oficinas relacionadas ao corpo e ao movimento com a coleta de relatos dos participantes.

\section{METODOLOGIA}

Participaram do estudo 15 (quinze) estudantes de diversos cursos da disciplina Psicologia Social na Educação da Faculdade de Educação da Universidade de Brasília (UnB).

A metodologia foi baseada na orientação transdisciplinar por meio de oficinas, construção de textos escritos e movimentos corporais.

O estudo foi desenvolvido durante quatro (4) encontros uma vez por semana no campus Darcy Ribeiro da Universidade de Brasília.

\section{Descrição dos Encontros:}

\section{1을 Encontro}

Despertamento Corporal:

Objetivo: Descontrair e desenvolver a percepção corporal de si e do grupo.

Dinâmicas integrativas e atividades com e sem músicas utilizando a percussão corporal, ritmo e o toque.

Ditado corporal - representação corporal das palavras. 


\section{2ํㅡㄹ Encontro}

Sentimento e forma/ Palavra e forma:

Objetivo: Desenvolver a percepção do ambiente, selecionando referenciais para composição de figuras e desenhos corporais.

Dinâmicas integrativas e atividades utilizando-se palavras com referências emocionais, como por exemplo: alegria, medo, prazer, etc.

Dinâmicas integrativas e atividades de pesquisa no meio ambiente com a escolha de um elemento vegetal, animal e mineral para representar corporalmente.

\section{3ํㅡㄹ Encontro}

O corpo interdisciplinar:

Objetivo: Pesquisar e selecionar conteúdos didáticos para serem desenvolvidos corporalmente.

Dinâmicas integrativas e atividades de pesquisa e seleção de conteúdos para representação corporal.

\section{4으 Encontro}

Lugar e texto do meu corpo:

Objetivo: Produzir um texto baseado no tema gerador.

A partir do texto gerador "Lugar e texto do meu corpo" produzir um texto individual.

Foram utilizadas questões para diferentes temáticas permitindo dessa forma, a construção de elaborações teóricas e práticas sobre a consciência corporal por meio do movimento, além de reflexões tais como:

- $\quad$ Posse do corpo e de si;

- Qual o lugar do corpo?

- Que textos corporais são considerados na sua escrita de mundo?

- Qual o discurso do corpo nos diferentes contextos?

- Diálogo corporal: Conhecendo e aprendendo o corpo.

Abaixo as atividades que foram utilizadas como oficinas, dinâmicas, construções de sequências e textos corporais:

- Despertamento/ movimento corporal;

- $\quad$ Sentimento, forma e movimento;

- $\quad$ Palavra e forma;

- Ditado: representação dos objetos no corpo.

- Corpo transdisciplinar.

No último encontro foi solicitada a produção individual manuscrita de considerações baseada no tema gerador: Lugar e texto do meu corpo.

\section{RESULTADOS}

Foram obtidas 15 produções individuais dos estudantes participantes do estudo. Abaixo algumas considerações apresentadas.

Participante A - Curso de Pedagogia:

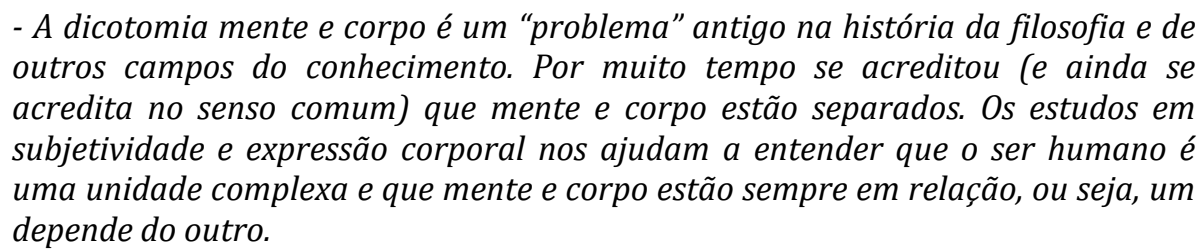

- A dicotomia mente e corpo é um "problema" antigo na história da filosofia e de outros campos do conhecimento. Por muito tempo se acreditou (e ainda se acredita no senso comum) que mente e corpo estão separados. Os estudos em subjetividade e expressão corporal nos ajudam a entender que o ser humano é depende do outro. 
Participante B - Curso de Pedagogia:

- O corpo demonstra e manifesta diversos aspectos do ser humano, como o físico, pessoal e emocional. Nesse sentido o corpo não se refere estritamente aos aspectos físicos e relacionados à aparência, mas reflete nossas sensações $e$ emoções. Durante as oficinas pode-se perceber as reações e emoções expressas através dos movimentos corporais, além do tempo de cada um. Perceberam-se alguns pontos sobre a personalidade de cada sujeito... Nesse sentido o meu corpo encontra-se extremamente travado e sistemático... Com o passar dos encontros comecei a trabalhar o meu corpo de forma mais leve e desimpedida.

Participante C - Curso de Psicologia:

- O lugar do meu corpo foi sendo moldado conforme cresci. Quando digo corpo me refiro ao físico e ao subjetivo, seja emocional ou mental. Durante meu amadurecimento fui aprendendo como me portar, como agir de acordo com determinadas situações. Fui ensinado a seguir normas. No entanto, mesmo que tal "encaixotamento" sirva para um convívio harmonioso em sociedade ele muitas vezes pode ter más repercussões. A pessoa pode desaprender a se ouvir, se expressar, a ser ela mesma. Talvez esse seja o lugar e texto do meu corpo atualmente em uma caixa de normas. No entanto esse curso me permitiu tomar certa consciência disso pra então eu me mudar.

Participante D - Curso Pedagogia:

- Descobri que meu corpo não é só físico. É biológico e emocional. É interno e externo. Ocupa um lugar. Tem diferentes papéis. Se expressa ainda que eu o cale. Não basta pensar é necessário sentir. Descobri que é preciso parar, respirar fundo, ouvir o que o corpo pede. Ele pede descanso no meio de tanta pressa. Pede movimento no meio da repressão. Pede paciência diante dos próprios limites. A mente não é sem o corpo, assim como eu não sou sem o outro. Não é separado é misturado. Faz parte de um todo e ainda assim tem sua singularidade. E ainda que se constitua pelas experiências externas é meu, interno com experiências e sentimentos próprios em busca do equilíbrio.

Participante E - Curso de Pedagogia:

- Posso estar onde quiser. Movimentar-me de todas as maneiras. Viajar parada. Posso imaginar o que quiser pensar, mil coisas em mil situações sem precisas estar parada. O lugar e o texto do meu corpo estão na minha cabeça. Fechando os olhos me tele transporto, mudo de lugar, saio do meu corpo, basta concentrar $e$ imaginar... Meu corpo às vezes é controlado. A mente nunca. Sei como não me mexer, como não me movimentar, como segurar alguns impulsos, como me manter quieta e estática. Como controlar a mente? ... Como mantê-la parada sem movimento?

\section{DIÁLOGOS}

A partir do tema gerador se observa por meio dos discursos apresentados uma questão que é recorrente nas oficinas, a pouca consciência de si. Oportunizar atividades corporais que contemplem a reflexão para o movimento favorece o desenvolvimento da percepção e consciência corporais.

O corpo transdisciplinar é um corpo integral e relacional, pois os aspectos materiais e imateriais são inscritos no físico, nas emoções, nos pensamentos, ideias e atitudes cotidianas. Strazzacappa, (2001, b), ao afirmar que toda educação é uma educação que envolve o corpo reconhece a dimensão de integralidade corporal, mesmo quando é esquecido ou silenciado.

Considerando o contexto das diversidades é importante salientar que não se deve desejar ou se buscar um corpo padronizado na escola, mas desenvolver estratégias para a gestão e diálogo entre os diversos. Algo nesse sentido pode ser exemplificado pela frase da participante C: "A pessoa pode desaprender a se ouvir, se expressar, a ser ela mesma". 
Uma questão que deve ser considerada relacionada à valorização das experiências vividas pelos atores das cenas cotidianas nos diversos contextos, ou seja, escolares, familiares e sociais. 0 mesmo corpo que se constitui a partir do externo possui aspectos e características próprias de singularidade.

Ambientes alegres atraem mais facilmente para novas descobertas. Especificamente em relação ao ambiente escolar, ao se propor atividades que possam relacionar o corpo em seus diferentes aspectos com os conteúdos haverá uma mobilização para a participação em função da inserção dos saberes e experiências pessoais de acordo com Medina (2009).

\section{CONSIDERAÇÕES PARA NOVOS MOVIMENTOS}

A partir das produções apresentadas pelos participantes observou-se que de um modo geral ocorreu o desenvolvimento de uma maior consciência corporal, permitindo reflexões individuais e em grupo sobre os elementos constituintes desse corpo.

Embora se viva no século XXI as questões relacionadas à separação entre o corpo (físico), a mente e as emoções ainda é algo recorrente. Muitos sujeitos não possuem a consciência do seu próprio corpo, priorizando as dimensões físicas e intelectuais em detrimento das emocionais.

O paradigma transdisciplinar abarca em primeira instância a dimensão humana na qual o indivíduo ao conhecer e reconhecer o seu corpo é capaz de apropriar-se de si articulando seus saberes, histórias e ações localizando-o no mundo. Merleau Ponty (1999) aponta o corpo como unidade mente-corpo em constante movimento relacionada a percepção para a leitura do mundo. Como unidade o corpo poderá ou não articular suas estruturas físicas, cognitivas, emocionais entre outras. Oportunizar experiências relacionadas a expressão do corpo poderá qualificar e desenvolver o conhecimento do sujeito em relação a si próprio e ao ambiente, legitimado dessa forma sua ação social.

Uma ampliação sobre a concepção do complexus apontado por Morin (2000) pode ser realizada quando se toma como referência inicial o próprio sujeito transdisciplinar que é capaz de realizar isso em si mesmo expandindo para suas relações.

As atividades corporais são ações que podem mobilizar dispositivos motivacionais com a valorização e inserção de experiências, sendo necessários ambientes alegres e diversificados com estímulos variados, segundo Medina (2009).

Utilizando-se como referência um estudo de Veiga (2014) relacionada à docência no Ensino Superior sobre a diversidade da prática docente, torna-se fundamental reconhecerem-se as diferentes concepções do professor em relação ao seu próprio corpo físico, emocional, subjetivo, cognitivo e outros.

O presente estudo pelos relatos e produções permitiu a conclusão de que o conhecimento do corpo é fundamental para o desenvolvimento de uma consciência e ação cidadã. Identidade e subjetividade, assim como o físico e a racionalidade, são elementos estruturantes de um mesmo indivíduo na sua dimensão de complexidade.

\section{REFERÊNCIAS}

[1] Cavalcanti, Katia. Brandão. Revista "Nova Atenas" de Educação tecnológica: Revista Eletrônica do Departamento Acadêmico de Ciências da Saúde. Educação Física e Esportes. Volume 07, Número 02, jul/dez/2004.

[2] Congresso de Locarno - Congresso Internacional: “Que Universidade para o amanhã”? Em busca de uma evolução transdiciplinar da universidade. Locarno, Suiça, mai. 1997. Disponível em: http://www.redebrasileiradetransdisciplinaridade.net Acesso em: 26 fev. 2010.

[3] Mauss, Marcel. Sociologia e Antropologia. São Paulo: Casac \& Naify, 2003.

[4] Maturana, Humberto; Varela, Francisco. De máquinas e seres vivos. Autopoiese - a organização do vivo. Trad. Juan Acuña Llorens. Porto Alegre: Artes Médicas, 1997.

[5] Medina, Alice Maria Corrêa. Atividades físicas e lúdicas como fator motivacional para desenvolver as inteligências múltiplas em crianças até oito anos. Educere, Revista da Educação da Unipar, v. 9, n.1, p.81-97, 2009.

[6] Merleau-Ponty, Merleau. Fenomenologia da Percepção. São Paulo: Martins Fontes, 1999.

[7] Moraes, Maria Cândida. Ecologia dos Saberes: complexidade, transdisciplinaridade e educação: novos fundamentos para iluminar novas práticas educacionais. São Paulo: Antakarana/WHH, 2008. 
[8] Morin, Edgar. 0 método 5. A humanidade da humanidade. Ed. Sulina, 2007.

[9] _. A cabeça bem-feita: repensar a reforma, reformar o pensamento. Tradu- ção de Eloá Jacobina. 9. ed. Rio de Janeiro: Bertrand Brasil, 2004.

[10] _ _ Os Sete Saberes Necessários à Educação do Futuro. Trad. Catarina Silva; Jeanne Sawaya. São Paulo: Cortez; Brasília, DF: UNESCO, 2000.

[11] Schwart, Gisele Maria. Linguagem corporal de expressão da criatividade e seu des (envolvimento) na educação física. Revista Motriz, v.3, n.2, p. 104-107, dez. 1997.

[12] Strazzacapa, Márcia. Técnicas Corporais - à procura do outro que somos nós mesmos. In: Revista do Lume, Unicamp, São Paulo, p.45-51, 2001 a.

[13] __. A educação e a fábrica de corpos: a dança na escola. Caderno Cedes. Campinas, no 53, p. 69-83, abril, 2001b.

[14] Suassuna, Dulce Maria Filgueira de Almeida; BARROS, Jônatas; Azevedo, Aldo; Sampaio, Juarez. A Relação Corpo-Natureza na Modernidade. Rev. Sociedade e Estado, Brasília, v. 20, n.1 p. 23-38, jan./abr. 2005.

[15] Varela, Francisco; Thompson, Evan; Rosch, Eleanor. A mente corpórea: ciência cognitiva e experiência humana. Tradução de Joaquim Nogueira Gil e Jorge de Sousa. Lisboa: Instituto Piaget, 2001.

[16] Veiga, Ilma Passos Alencastro. Formação de professores para a Educação Superior e a diversidade da docência. Revista Diálogo Educacional, v.14, n.42, 2014. 


\title{
Capítulo 13
}

Mapeando o corpo humano - sistemas: Da formação continuada para a sala de aula

\author{
Dilma Nazaré dos Anjos Silva da Fonseca \\ Evanilda Figueiredo Gonçalves da Silva \\ Ana Lúcia Barros de Andrade \\ Lucilene Pacheco Santos
}

Resumo: A presente discussão pretende evidenciar o processo da formação continuada para o professor como dimensão necessária ao desenvolvimento de sua prática, essa faceta legal da educação deve estar disponível a todo o profissional a fim de que o mesmo por sua vez, se utilize de seus benefícios. Uma formação continuada de qualidade reflete resultados positivos na sala de aula, conforme apresentado nesse artigo na forma de atividade lúdica para o ensino do componente curricular de Ciências para o 5ํano do Ensino Fundamental em uma escola municipal de Manaus, aplicada em sala de aula após uma das formações realizadas pela Secretaria Municipal de Educação de Manaus SEMED. A partir da dinâmica socializada surgiu "Mapeando o Corpo Humano - sistemas" que à primeira vista traz a oportunidade de apresentar uma aula atrativa, de fixar a aprendizagem e cumprir o currículo extenso em um curto espaço de tempo. Para, além disso, pôde-se perceber ao final da atividade o despertar dos aspectos sócio afetivos na partilha de interesse entre os alunos durante o trabalho coletivo, o cumprimento dos combinados, o desenvolvimento da oralidade na apresentação avaliativa e a ativação dos conhecimentos prévios dos alunos demostrados na associação do assunto trabalhado com vivências do cotidiano. Desse modo, a partir do êxito da ação realizada percebida também na elevação do rendimento bimestral, é possível apontar um olhar mais cuidadoso com as oportunidades de crescimento e amadurecimento que a formação continuada oferece ao ensino aprendizagem, mas é para aquele que deseja um fazer efetivo e transformador.

Palavras-chave: ludicidade, aprendizagem significativa, corpo humano. 


\section{INTRODUÇÃO}

Neste texto, apresentamos nosso relato de experiência no âmbito da Secretaria Municipal de Educação SEMED, em que mediante a realização de uma aula diferenciada em uma escola pública municipal de Manaus, pudemos observar as potencialidades de se trabalhar o lúdico em sala dentro da temática do corpo humano, a partir de uma formação continuada. 0 trabalho foi desenvolvido em uma escola da rede pública municipal de Manaus, com alunos do $5^{\mathrm{o}}$ ano, do ensino fundamental 1. Tendo como referencial teórico a aprendizagem significativa, a experiência relata a contribuição da ludicidade na construção de conhecimento pelos educandos e as possibilidades do trabalho em sala de aula, atingindo os alunos como um todo e facilitando o processo de aprendizagem. 0 trabalho em grupo, atividades de desenho contextualizadas são exemplos de estratégias metodológicas que foram utilizadas. A avaliação da experiência se deu através da prática oral, com a exposição dos trabalhos, onde os alunos puderam ser observados e analisados, a partir da fala descritiva sobre os sistemas do corpo humano. Os resultados demonstraram um ganho com o envolvimento dos alunos, mostrando um considerável entendimento do assunto, sendo essas aulas mais favoráveis para a sua aprendizagem.

Diante do exposto, o trabalho teve como objetivos: fixar de forma significativa o aprendizado dos alunos; realizar uma aula atrativa e participativa; cumprir com o currículo num curto espaço de tempo, mediante a extensão da proposta curricular.

O desenvolvimento de uma prática pedagógica significativa no cerne da sala de aula, requer do profissional da educação lançar mão de inúmeros recursos os quais nem sempre estão à mão e por isso exigem um espaço específico para instrumentalizá-lo, o qual não está na rotina corrida dos afazeres que lhes são peculiares na escola. A formação continuada entra nesse processo apontando novas possibilidades para fortalecer as metodologias já desenvolvidas pelo professor.

Uma das possibilidades efetivas trazidas nas formações promovidas pela Secretaria Municipal de Educação - SEMED por meio da Divisão de Desenvolvimento Profissional do Magistério - DDPM, diz respeito à ludicidade, dimensão da aprendizagem necessária à manutenção da motivação de docentes e discentes.

Em umas dessas formações ocorridas em 2018 para o componente curricular de Ciências, a formadora socializou uma dinâmica que permite explorar inúmeras possibilidades incluindo o conteúdo dos Sistemas do Corpo Humano, conforme aplicada com turmas do $5^{\circ}$ ano de uma escola municipal de Manaus, no segundo bimestre de 2019. "Mapeando o Corpo Humano - sistema", além de ser uma aula atrativa, promove a fixação do aprendizado e auxilia no cumprimento do currículo, em um curto espaço de tempo dada a extensão da proposta curricular. Na turma mencionada, a aula atrativa sai do lugar comum e acha espaço no interesse individual e na contextualização de cada aluno, tornando-se uma prática exitosa.

Esse movimento estreita a relação professor-aluno, proporcionando uma troca de experiências e conhecimentos, pois ambos interagem num processo onde não é mais 'possível conceber a aprendizagem como uma atividade somente de representação ou cumulativa. Segundo COLAUTO et al (2019), as propostas didáticas precisam se originar a partir da união de duas variáveis importantes: os objetivos do ensino e as possibilidades de aprendizagem oferecidas para os alunos. Trabalhar com o lúdico pode oportunizar aos alunos uma expressão positiva de suas emoções, permitindo que o professor consiga envolver a atenção dos mesmos para o conteúdo e as atividades propostas em sala de aula, bem como, transferir a eles a vontade de aprender. POZO e CRESPO afirmam que

Frente a outras espécies, que dispõem, em um alto grau, de condutas geneticamente programadas para se adaptar a condições muito mais variáveis e imprevisíveis, em grande medida devido a própria intervenção da cultura, e, portanto, precisam dispor de mecanismos de adaptação mais flexíveis, que não podem estar pré-programados. Em resumo, nós precisamos de processos de aprendizagem muito potentes. (POZO e CRESPO, p.22, 2009)

Dessa forma compreende-se a importância de uma aula diversificada, mas acima de tudo planejada de maneira que a mesma possa sofrer adaptações e flexibilidade em torno dos objetivos a serem alcançados.

0 texto deste artigo apresenta um breve relato do que foi possível perceber ao longo do trabalho realizado e indica as possibilidades do lúdico para a aprendizagem significativa dos alunos, a partir da abordagem de conteúdos sobre o corpo humano. 
Por acreditarmos no seu potencial pedagógico, verificamos que o lúdico quando utilizado como estratégia de interação, pode propiciar a aprendizagem de conteúdos no ensino de ciências, mediante sua capacidade de envolver e motivar os alunos.

\section{METODOLOGIA}

O trabalho foi realizado em uma escola pública municipal de Manaus e os sujeitos que participaram deste processo foram os alunos do 5 ano do ensino fundamental da referida escola. 0 ponto central deste trabalho se concentrou no trabalho pedagógico do professor, por reconhecermos que nosso objeto de análise atua como estratégia didática para o ensino e aprendizagem dos sistemas do corpo humano.

0 método do trabalho foi construído acerca de uma abordagem qualitativa, com características de uma pesquisa participante, ressaltando suas peculiaridades, onde o ambiente natural é a fonte direta de dados e o professor pesquisador como seu principal instrumento. Desta forma, aceitamos que esta técnica de investigação pressupõe o contato direto do professor pesquisador com o ambiente e a situação que está sendo analisada (BOGDAN e BICLEN, 1994)

A escola onde foi realizada a aula diferenciada, atende o ensino fundamental nos turnos matutino e vespertino. Os sujeitos do processo foram alunos e professora pesquisadora do ensino fundamental 1 do 5 ano, na disciplina de ciencias, por trabalharem os sistemas do corpo humano em um nível mais detalhado, onde esses alunos ao final do curso, precisam conhecer parcialmente órgãos e funções do corpo.

Para a coleta de dados, utilizamos a documentação direta norteados por Lakatos (2017, p.188) que explica que esta técnica "constitui-se, em geral, no levantamento de dados no próprio local onde os fenômenos ocorrem". Desta forma, realizou-se uma exposição oral e a partir da descrição feita pelos alunos, a professora pesquisadora pode coletar dados que embasaram a discussão dos resultados, técnica essa caracterizada pela observação participante. Thiollent (2002, p.64) descreve que independente de qual técnica seja utilizada, "os grupos de observação compostos de pesquisadores e de participantes comuns procuram a informação que é julgada necessária para o andamento da pesquisa."

\section{DESENVOLVIMENTO}

A formação continuada de professores é compreendida como um processo permanente e constante de atualização e enriquecimento de saberes essenciais para a prática docente dos professores. Essa formação é um direito adquirido aos professores, mas para que ela gere frutos, é necessário que a mesma seja significativa ao trabalho destes professores. Neste sentido, Furtado (2017) comenta que se for significativa, o objetivo da mesma estará sendo alcançado. Ainda descreve que

[...] as atividades de capacitação docente têm apresentado baixa eficácia porque são desvinculadas da prática; dão excessiva ênfase a aspectos normativos e não traduzem projetos coletivos e institucionais. Tais deficiências nos programas de formação continuada, muitas vezes, têm levado ao desinteresse e à reações de indiferença por parte dos professores, por perceberem que certas atividades que prometem ser de formação, quase sempre, em nada contribuem para seu desenvolvimento profissional. Alguns autores apontam que o segredo do sucesso de um bom programa de formação continuada resume-se a três fatores: partir das necessidades reais do cotidiano escolar do professor; valorizar o seu saber e a sua experiência e integrar de forma eficaz, teoria e prática. Com relação a esse último fator, precisamos ficar atentos para que o processo de formação não se constitua num receituário pedagógico. Os processos de formação continuada podem ser valiosíssimos, se conseguirem aproximar os pressupostos teóricos e a prática pedagógica. A formação continuada deve ser capaz de conscientizar o professor de que teoria e prática são "dois lados da mesma moeda", que a teoria o ajuda a compreender melhor a sua prática e a lhe dar sentido e, consequentemente, que a prática proporciona melhor entendimento da teoria ou, ainda, revela a necessidade de nela fundamentar-se. (FURTADO, 2017. Disponível em http://juliofurtado.com.br/2015/07/22/aimportancia-da-formacao-continuada-dos-professores/. Acesso em 20/09/19. 
A formação continuada também permite a reflexão sobre a prática, portanto, deve-se estar preparado para interagir com as diversas dinâmicas da aprendizagem, que tem apenas um início na graduação e vai sendo complementada ao longo do amadurecimento profissional, como GROCHOSKA (2014, p.129) destaca essa diferença.

Entende-se por formação inicial aquela que acontece nos cursos de graduação e por formação continuada aquela que se dá ao longo da carreira do docente, por meio de assessoramentos, cursos e palestras ou de estratégias propostas pelos sistemas de ensino, pelas Secretarias de Educação e, em especial, pela própria escola (se previsto em seu PPP) e que são parte do processo de organização escolar. (GROCHOSKA 2014, p.129)

A atratividade no ensino de Ciências é um diferencial inquestionável, é um componente curricular muito visual, não faz sentido ficar apenas no campo da abstração e para que os alunos do 5o ano pudessem não apenas apreciar, mas apropriar-se dos conteúdos abordados, foi necessário que a aula tivesse um diferencial denominado "Mapeando o Corpo Humano - sistemas", desenvolvido na sala de aula da seguinte forma:

1. Exposição oral sobre Os Sistemas do Corpo Humano com auxílio de painéis ilustrativos, apresentados pela professora. Nesta primeira etapa, a professora fez a explanação dos sistemas do corpo humano, utilizando material didático disponível na escola.

2. Desafiando a turma a reproduzir os sistemas. A proposta da atividade foi apresentada aos alunos, definindo regras e orientações gerais. Os alunos receberam a responsabilidade de reproduzir um sistema do corpo humano.

3. Organização dos alunos em equipes de acordo com a quantidade de sistemas abordados. Após a explanação, as equipes formadas receberam o nome do sistema do corpo humano para desenvolver a atividade.

4. Cada equipe recebe um dos painéis ilustrativos dos sistemas para orientação durante a atividade, disponibilização de papel madeira, lápis de cor e pincéis.

5. Um dos integrantes da equipe deita sobre o papel madeira (papel disponível no momento), e os demais deverão traçar o contorno do corpo em tamanho real (Figura 1).

6. Cada equipe deverá mapear o corpo do aluno escolhido a fim de reproduzir um dos sistemas. Em todos os passos da atividade a equipe deve se organizar para distribuir adequadamente as tarefas.

7. A equipe faz a ilustração de cada órgão que compõe o sistema, nomeando-os e colorindo-os. Esta tarefa exige organização e interação da equipe.

8. Conclusão com a exposição visual e oral de cada sistema e suas respectivas funções por cada equipe. Esse é o momento da socialização do trabalho, onde as outras equipes conhecem os outros trabalhos e dialogam entre si.

9. Montar o mural dos Sistemas do Corpo Humano na sala para as próximas retomadas do conteúdo.

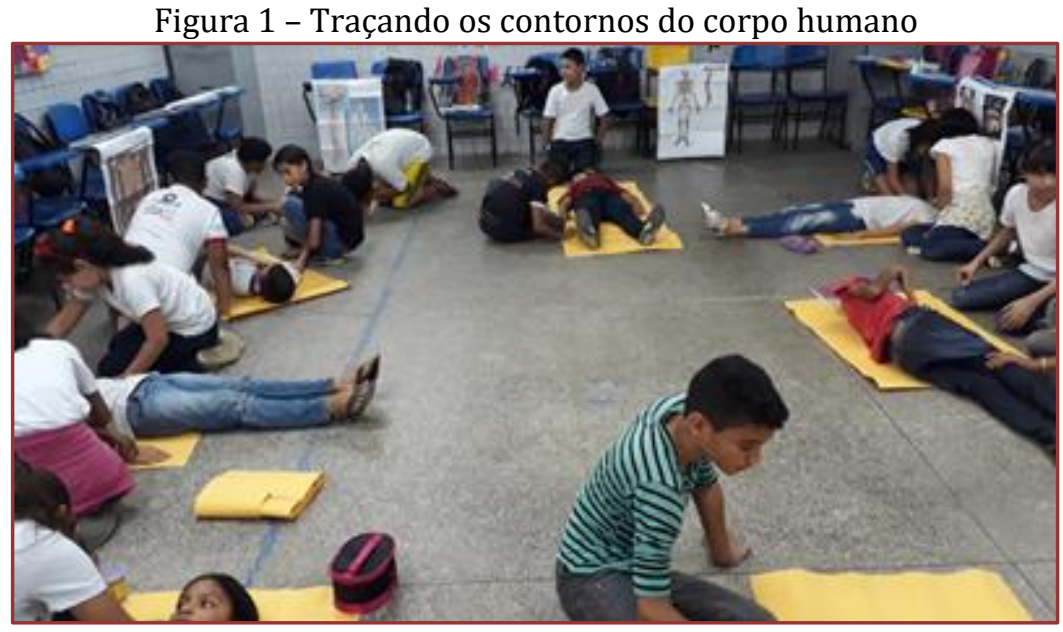

Fonte: D. N. S. F, 2019 
A criança utiliza a linguagem para se expressar e organizar o seu pensamento e dessa forma consegue interagir com seu meio. Vygotski considera de grande importância para o processo de interação entre as crianças o convívio social que interfere positivamente no desenvolvimento humano, justificando seu grande interesse no estudo da infância. Ele também acreditava que o desenvolvimento infantil necessitava de um desenvolvimento da maturação da organização integral do organismo, tendo em vista que "a mente dela contém todos os estágios do futuro desenvolvimento intelectual: eles existem já na sua forma completa, esperando o momento adequado para emergir" (VYGOTSKI, 1994).

\section{RESULTADOS E DISCUSSÃO}

Trazer a prática realizada em um dia de formação docente para o cotidiano da sala de aula revela a abertura do professor em desenvolver uma prática diferenciada, customizada e efetiva, uma vez que sua tarefa principal é o ensino, promover a aprendizagem por meio do conhecimento, deve estar ligado a iniciativas de formação e respeitar o tempo de resposta de seus alunos.

A ludicidade é aquela surpresa que o professor tira da bolsa, um de seus instrumentos de motivação e por isso precisa ter um viés real de atratividade respaldado pelo planejamento intencional, de acordo com Antunes (2012, p.47),

O que determina a qualidade da ferramenta é o serviço que se precisa fazer e, se a aula é uma ferramenta de aprendizagem, que se descubra diferentes maneiras de ministrar aulas, uma vez que é ingênuo supor que uma ferramenta só se mostre eficiente para diferentes aprendizagens.

Mapear o corpo humano a fim de apropriar-se de modo geral dos sistemas e órgãos que os compõem bem como suas funções foi um processo avaliativo desde sua concepção, uma atividade predominantemente artística e visual, na qual sua avaliação teve culminância com a prática oral, prática avaliativa que fortalece o rendimento do aluno. Após cada equipe concluir seus painéis ilustrativos, chegou o momento das apresentações não só para apreciação como também para explicação, mostrar o quanto aprenderam.

Os componentes dos grupos destacaram a formação, função e organização e os órgãos componentes de seu sistema respectivamente, tarefa geradora de nota parcial para o $2^{\circ}$ bimestre. 0 esforço coletivo e individual rendeu excelente desempenho quantitativo e qualitativo, este merece evidência uma vez que contribuiu com o desenvolvimento sócio afetivo da turma quando partilharam interesses e ajuda ao outro e ativando as memórias de seus conhecimentos prévios demostrados ao fazem comparativos com suas vivências.

Fazer com que os alunos se percebam como parte integrante do processo é essencial. A aprendizagem torna-se significativa quando os alunos conseguem visualizar o que nos livros didáticos ainda pode estar implícito. Em outras palavras, é muito mais significativo compreender as estruturas de um órgão do corpo humano quando se visualiza o mesmo em tamanho natural. Os alunos usam como moldes e parâmetros o seu próprio corpo e excluem a ideia minimizada que é explorada nos livros, onde observam esses mesmos órgãos em tamanho reduzido, longe da realidade virtual dos mesmos.

Com a ferramenta lúdica aprendida na formação continuada e aplicada na sala de aula, observou-se o interesse dos alunos em realizar a atividade e o cuidado ao realizar os desenhos com riqueza de detalhes, como é observado na figura 2. 


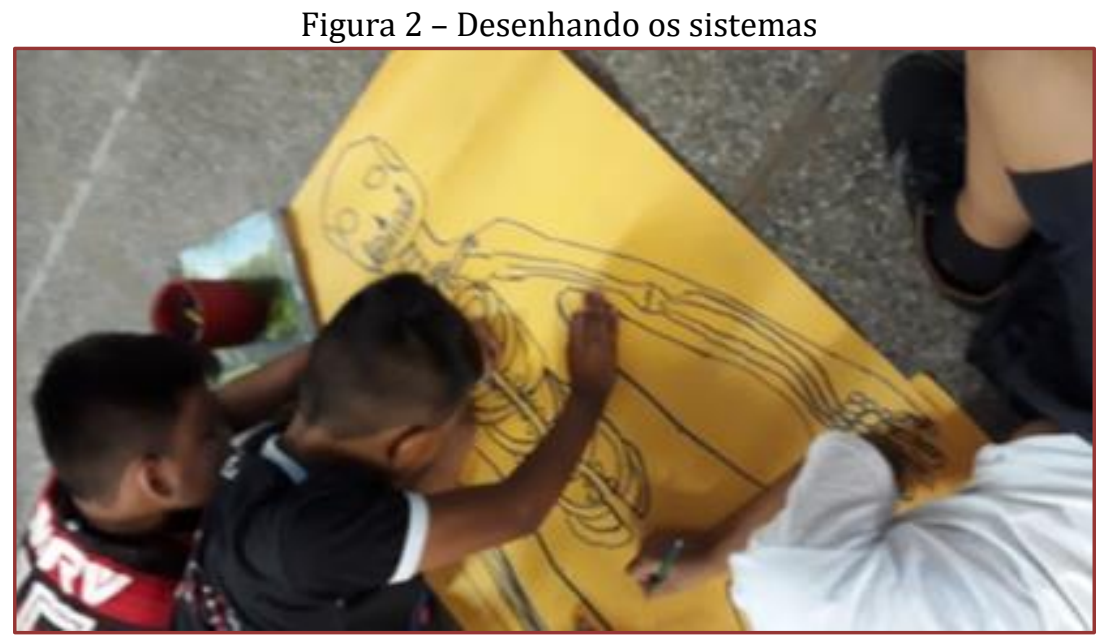

Fonte: D. N. S. F, 2019

A aquisição do domínio do conteúdo na exposição oral, vontade em partilhar o conhecimento na exposição visual, cumprimento dos combinados foram evidenciados na socialização dos trabalhos (figura 3), além da elevação do rendimento bimestral para a respectiva disciplina. Os painéis feitos pelos alunos formaram um mural na sala utilizado também para ilustrar as aulas do $5^{\circ}$ ano.

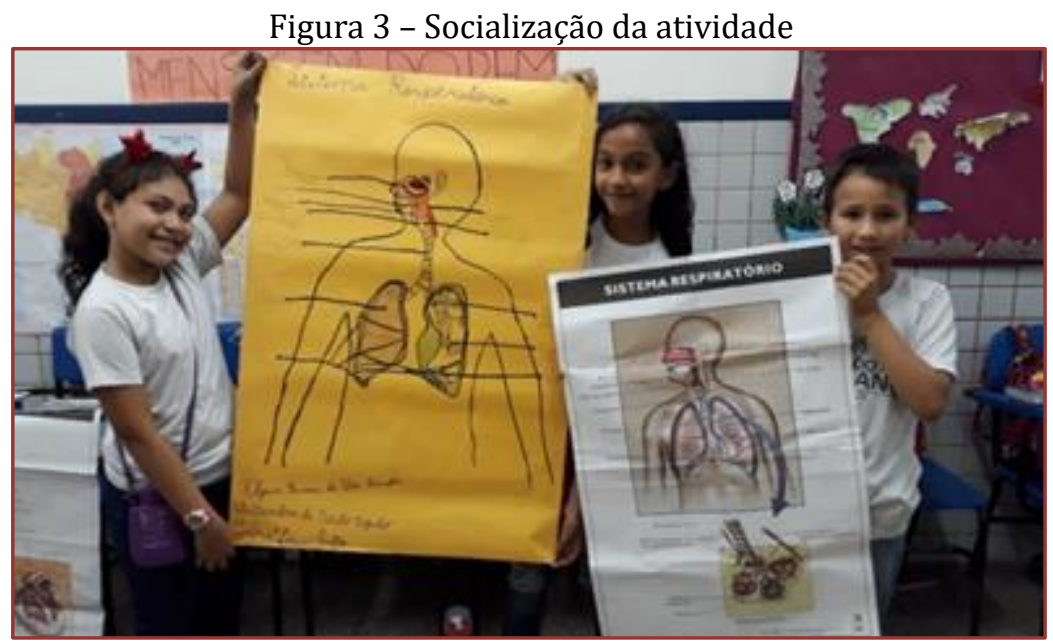

Fonte: D. N. S. F, 2019

Reforçar a aprendizagem de forma lúdica pressupõe apreensão do conhecimento e socialização do mesmo, perceptível na fala dos alunos quando associam o conhecimento adquirido durante as atividades diferenciadas em outras situações cotidianas na própria escola.

É a prática formativa do mediador que também aprende, amplia seus saberes e constrói sua identidade profissional, contudo não fará sozinho, para (PIMENTA E FRANCO et al São Paulo, 208, p.54), " a autonomia docente não é uma capacidade individual de cada professor, mas um processo de construção permanente de emancipação pessoal e coletiva dos implicados na prática educativa". Longe de ser atenuante de fragilidade, mas uma edificação saudável inserida nos contextos sociais de pertencimento.

\section{CONSIDERAÇÕES FINAIS}

Perceber-se agente construtor de conhecimento, parte importante na mediação da aprendizagem empodera o profissional docente. 
Para além das valorizações trabalhistas tão fundamentais, está a satisfação de ver seus alunos com as mentes inquietas em busca de conhecimento, aquele sorriso no rosto de contentamento e orgulho por ter entendido a "brincadeira" que o professor fez, por ter se superado. É como se sentem após cada desafio, e com o mestre, não é diferente, ao desafiar os alunos, se desafia também, por isso precisa buscar conhecimento e instrumentalizar suas práxis longe de modelos engessados.

Assim sendo, valorizar as oportunidades de crescimento profissional deve estar no topo da lista de objetivos do professor, perceber a formação continuada como uma intervenção produtiva em seu fazer, e a atratividade das aulas não como mais uma trabalheira, e sim, como uma aliada na transmissão e assimilação dos conteúdos e na reelaboração do saber, tão necessários para a formação de uma sociedade pensante.

\section{REFERÊNCIAS}

[1] Antunes, Celso. (In) Disciplina e (Des) Motivação. São Paulo: Paulus, 2012.

[2] Bogdan, Robert. Biklen, Sari. Investigação qualitativa em Educação: Uma introdução à Teoria e aos Métodos. Porto Editora, PT, 1994.

[3] Colauto, R. D. Silva, O. L. da. Tonin, J. M. da. F. Martins, S. P. Revolucionando a sala de aula. [Orgs] Edvalda Araújo Leal, Gilberto José Miranda, Silvia Pereira de Castro Casa Nova.-1.ed. [3. Reimpr.]. - São Paulo: Atlas, 2019.

[4] Furtado, J. A importância da formação continuada dos professores. 2017. Disponível em < http://juliofurtado.com.br/2015/07/22/a-importancia-da-formacao-continuada-dos-professores/> Acesso em 20/09/19.

[5] Grochoska, Marcia Andreia. Organização escolar: perspectivas e enfoques. 2. ed. Curitiba: InterSaberes, 2014.

[6] Lakatos, E. M. Marconi, M. de A. Fundamentos de Metodologia Científica. 6. ed. São Paulo: Atlas, 2007.

[7] Pimenta, Selma Garrido; Franco, Maria Amélia Santoro [Orgs]. Pesquisa em Educação: Possibilidades investigativas/formativas da pesquisa-ação. São Paulo: Edições Loyola, 2008.

[8] Pozo, J. I. Crespo, M. A.G. A aprendizagem e o ensino de ciências: do conhecimento cotidiano ao conhecimento científico. Tradução Naila Freitas. 5. Ed. Porto Alegre: Artmed, 2009.

[9] Thiollent, M. Metodologia da pesquisa-ação. 11. Ed. São Paulo: Cortez, 2002.

[10] Vygotsky, L. S. A formação social da mente. 2ª ed. São Paulo: Martins Fontes, 1994. 


\section{Capítulo 14}

\section{A Legislação Brasileira e a formação continuada dos professores: Teoria e prática}

\section{Farbênia Kátia Santos de Moura}

Resumo: 0 referido texto aborda alguns dos documentos da Legislação Brasileira, tais como: a LDB - Lei de Diretrizes e Bases da Educação Brasileira, Lei 9394/96; PNE 2001 2010, Primeiro Plano Nacional de Educação; PNE 2014-2024, Plano Nacional de Educação atual. Com o intuito de recortar destes documentos, o que os mesmos apresentam acerca da formação continuada dos docentes, especificamente dos professores que atuam no Ensino Fundamental, comparando com o que de fato é posto em prática no município de Limoeiro do Norte - CE, mais especificamente na escola X da Rede Pública de Ensino. Nesta linha de raciocínio, os objetivos deste artigo são: Analisar o que apresentam as Leis acerca da Formação Continuada dos Docentes e em que contexto foram sancionadas; Refletir sobre o que é exposto teoricamente nos documentos em comparação com o que se é concretizado no Município de Limoeiro do Norte-CE, mais especificamente na escola X. Perceber os distanciamentos e/ou aproximações do que se constam nestes documentos e do que está acontecendo de fato, se faz jus, para que todo professor possa compreender melhor os prós e os contras da situação educacional no Brasil como um todo. Deste modo, o presente artigo é de cunho documental e bibliográfico, com base nas seguintes Legislações Brasileiras de Educação: LDB - 9394/96, PNE - 2001-2010, PNE - 2014-2024; e em literaturas, como: Ghiraldelli Jr. (2009), Agliard (2012), Welter (2012), Pierosan (2012), entre outros.

Palavras-chave: Formação Continuada, PNEs, LDB, Teoria, Prática. 


\section{INTRODUÇÃO}

Este artigo aborda uma questão pertinente de ser refletida, que é justamente a análise do que está escrito nas Leis e o que se concretizou e/ou se concretiza no âmbito educacional, mas estritamente se tratando da formação continuada dos docentes. Far-se-á recortes das seguintes Legislações da Educação Brasileira: LDB - Lei de Diretrizes e Bases, Lei 9394/96; PNEs 2001-2010, 2014-2024; a fim de enfatizar o que diz respeito às Políticas de Formação Continuada, fazendo em paralelo uma comparação com o que foi ou está sendo concretizado no município de Limoeiro do Norte - CE, mais especificamente numa escola pública dos Anos Iniciais do Ensino Fundamental, assim como, provocando uma reflexão acerca dos distanciamentos ou aproximações entre o que está escrito, ou seja, o que é apresentado na teoria, e que está sendo posto em prática. Há também o intuito de compreender os contextos, os quais tais Leis foram formuladas, para que as mesmas sejam analisadas de forma contextualizada, e não de forma solta e neutra.

Estes documentos da Legislação Brasileira que regem a educação tratam da Formação Continuada, em termos gerais, mais relacionada a cursos de pós-graduação, stricto senso e lacto senso, ou seja, as especializações, os mestrados e doutorados. Não foi identificada nenhuma proposta de acompanhamento profissional em serviço, tendo as necessidades que surgem no "chão da escola", para que sendo refletidas, aprofundadas, fossem sendo superadas, melhoradas, considerando a escola como ponto de partida e ponto de chegada.

Todas essas Legislações constam objetivos e metas com prazos curtos e/ou longos para o alcance das mesmas. No entanto, em um país diverso como o Brasil, com inúmeras realidades diferentes, onde os principais setores: econômico, social, cultural, educacional, caminham de formas variada e desigual, ou seja, em algumas regiões mais favorecidas, até mesmo por questões climáticas, entre outras, a tendência é que a implantação de propostas seja realizada com mais afinco. Por outro lado, em regiões menos desenvolvidas, que enfrentam um número de problemas maiores, tudo se torna mais difícil de implantar, ainda mais quando não se leva em consideração as especificidades de cada realidade, de cada região.

Na LDB - Lei de Diretrizes e Bases, № 9393/96, Lei maior que rege a Educação Brasileira, constam alguns artigos e incisos que tratam da Formação Continuada dos Docentes da Educação Básica, de forma bem ampla, mais especificamente no Título VI - Dos Profissionais da Educação.

No PNE 2001 - 2011 - Plano Nacional de Educação passado, aparece de forma mais detalhada alguns pontos que estão relacionados à Política de Formação Continuada dos professores. Já em sua introdução, no tópico dos Objetivos e Prioridades, é explícita a atenção que se pretende dar a Formação tanto Inicial, como Continuada; e no Capítulo IV, intitulado: MAGISTÉRIO DA EDUCAÇÃO BÁSICA, no tópico 10 FORMAÇÃO DOS PROFESSORES E VALORIZAÇÃO DO MAGISTÉRIO, onde vem tratando de muitos aspectos que dizem respeito à Docência, mais diretamente à Formação.

No PNE 2014 - 2024 - Plano Nacional de Educação vigente, foram ampliados alguns prazos para metas do PNE passado, que não foram superadas, bem como a elaboração de novas metas e estratégias, ou mesmo, a reformulação, já que como segundo PNE, obviamente houve uma avaliação do antigo PNE, para que a elaboração deste novo PNE fosse construída, baseada na superação dos problemas do antigo PNE. Então, em algumas das metas deste novo PNE, é possível identificar o que se almeja atingir com as Políticas de Formação Continuada dos Docentes.

A escola visitada, da rede municipal de Limoeiro do Norte - CE, é composta pelas séries que compreendem os Anos Iniciais do Ensino Fundamental, do $2^{\circ}$ ao $4^{\circ}$ ano, com uma faixa etária de crianças, entre 7 e $10 \mathrm{ou}$ 11 anos de idade. 0 quadro de docentes é composto por 13 professoras, todas efetivas e bem experientes na profissão. A escola funciona nos dois turnos diurnos, e nas séries dos $3^{\circ} \mathrm{s}$ e $4^{\circ} \mathrm{o}$ s anos, acontece o rodízio de professoras por disciplinas, e a polivalência nas séries dos $2^{\circ} \mathrm{s}$ anos. 0 quadro de discentes apresenta um número de 460 a 470 alunos, sendo distribuídos em cinco $2^{\circ} \mathrm{s}$ anos, seis $3^{\circ} \mathrm{s}$ anos e seis $4^{\circ} \mathrm{s}$ anos.

Sobre a Formação Inicial das professoras, a maioria é graduada, porém, nem todas em Pedagogia; três das professoras estão cursando a graduação e uma professora não está cursando nenhuma graduação, tem apenas o curso normal. Quanto à Formação Continuada, uma minoria tem especialização ou ainda está cursando, em faculdades particulares, as quais alegam que acham bem melhor, pelo tempo reduzido de formação.

\section{METODOLOGIA}

0 presente artigo é de cunho documental e bibliográfico, com base nas seguintes Legislações Brasileiras de Educação: LDB - 9394/96, PNE - 2001-2010, PNE - 2014-2024; em literaturas, como: Ghiraldelli Jr. 
(2009), Agliard, Welter, Pierosan (2012), entre outros; bem como, utiliza-se de observações feitas na escola $\mathrm{X}$, como parte de um estudo de caso que foi sendo desenvolvido.

\section{DESENVOLVIMENTO}

No Brasil não dificilmente se escuta o discurso de que "a teoria é distante da prática", assim como "tudo no papel é bem feito, bem elaborado, mas na prática muitas coisas não são concretizadas". Essa discussão inclusive faz parte do meio acadêmico, ou seja, há uma preocupação de que entre essas duas vertentes (teoria e prática) haja uma interligação muito forte, que por sinal se faz necessária.

Observando algumas Leis que orientam o setor educacional no Brasil, tal discurso também se faz presente, principalmente em regiões menos favorecidas, onde o número de pobres é maior, e consequentemente a desigualdade em todos os aspectos também

Tomando por base as Legislações já citadas, com um recorte para as Políticas Públicas de Formação Continuada, fazendo um comparativo com o que está sendo posto em prática com as professoras da escola pública X, do município de Limoeiro do Norte - CE, percebe-se ainda certo distanciamento entre o que está escrito nas Leis e o que se concretiza de fato. Ao longo do texto, far-se-ão alguns apontamentos neste sentido.

No entanto, é importante conhecer e entender como se planejou tais Leis, ou seja, em que contextos foram pensadas e aprovadas, para assim, perceber as intencionalidades que prevaleceram.

Deste modo, faz-se um breve passeio histórico, com o intuito de relatar o planejamento e aprovação destas Legislações da Educação Brasileira. A começar pela LDB - Lei № 9394/96. Segundo Ghiraldelli Jr.:

A lei de Diretrizes e Bases da Educação Nacional resultou de intensa luta parlamentar e extra-parlamentar. Entidades da sociedade, com interesses diversos, porém convergentes em relação à defesa do ensino público e gratuito, se reuniram em vários momentos, criando versões de uma LDB de seu agrado. Todavia, a LDB resultante não foi esta, mas uma mescla entre o projeto que ouviu os setores da população e o projeto do Senador Darcy Ribeiro. É certo que a influência do segundo projeto sobre o primeiro foi preponderante. $(2009$, p. 170)

Dessa forma, se percebe que a LDB tomou um rumo de acordo com o que o governo queria, ou seja, satisfez os interesses do governo, que tinha na época Collor de Melo como presidente da República. Tais interesses não estavam prioritariamente vinculados à camada dos menos favorecidos. Obviamente que houve avanços e benefícios, em comparação com o período de Ditadura Militar, especialmente em relação ao ensino público obrigatório. No entanto, sobre a formação de professores, mais especificamente os professores do Ensino Fundamental, a LDB pode-se dizer que regrediu, no sentido do nível do grau de instrução dos mesmos.

Um ponto polêmico na LDB se configurou no que diz respeito à formação de professores, em especial o professor do Ensino Fundamental. De modo geral, a LDB firmou que para ser professor, no Brasil, seria necessário ter formação superior. Todavia, quanto ao professor de educação infantil e das quatro primeiras séries do Ensino Fundamental, a LDB inovou de forma inesperada: manteve a existência do curso de pedagogia, gerou a existência de um substituto da habilitação magistério, já então desaparecida e transformada na modalidade Normal em nível médio (...) (GHIRALDELLI, 2009, p. 173)

Em se tratando de Formação Inicial, dar a entender que, para se lecionar na Educação Infantil e Anos Iniciais do Ensino Fundamental, o professor não precisa ter uma formação mais sólida, como se bastasse saber apenas o básico para ensinar as crianças egressas nestas séries e nestes níveis. 0 que se permite perceber a precariedade da formação docente e em consequência disso, os reflexos na prática pedagógica e no processo de ensino e aprendizagem.

É justamente em seu Título VI - Dos Profissionais da Educação, mais precisamente no Artigo 62, que a LDB apresenta a condição para a formação inicial dos professores da educação básica:

Art. 62. A formação de docentes para atuar na educação básica far-se-á em nível superior, em curso de licenciatura, de graduação plena, em universidades e institutos superiores de educação, admitida, como formação mínima para o 
exercício do magistério na educação infantil e nas quatro primeiras séries do ensino fundamental, a oferecida em nível médio, na modalidade Normal. (BRASIL, 1996, p.38)

Por outro lado, aponta-se como ponto positivo a questão dos institutos superiores de educação, que segundo a LDB, em seu artigo 63, estes institutos seriam responsáveis por:

I - cursos formadores de profissionais para a educação básica, inclusive o curso normal superior, destinado à formação de docentes para a educação infantil e para as primeiras séries do ensino fundamental;

II - programas de formação pedagógica para portadores de diplomas de educação superior que queiram se dedicar à educação básica;

III - programas de educação continuada para os profissionais de educação dos diversos níveis. (BRASIL, 1996, p. 38)

Neste sentido, entende-se que estes Institutos dariam todo o suporte pedagógico e didático na formação do professor. Dando ênfase ao inciso III, que trata da formação continuada, formação esta, necessária na carreira docente de todo professor, se percebe na Lei a preocupação em promover e ascender os professores a conhecimentos mais elevados, mais consistentes, o que possibilita fazer de sua prática, uma atividade mais enriquecedora e significativa para os alunos, bem como para o próprio professor.

No entanto, na cidade de Limoeiro do Norte-CE, não existe estes institutos destinados somente para cumprir tais funções que constam na LDB. Antigamente, em uma escola estadual de ensino médio, oferecia-se o nível normal, o antigo "pedagógico", o qual daria o direito daqueles alunos exercerem o cargo de professores da educação infantil e anos iniciais do ensino fundamental. Atualmente, o curso normal não acontece, sendo as escolas estaduais, responsáveis pelo nível médio, que se chama de "científico".

Em relação à formação continuada, na cidade de Limoeiro do Norte - CE, acontecem os cursos de especializações em faculdades privadas, que normalmente funcionam em um ou dois finais de semana por mês, durante um período de dois anos. É importante frisar que, a cada ano se cresce mais o número de estudantes nestas faculdades, tanto nos cursos de graduação, quanto nos cursos de pós-graduação. De acordo com alguns depoimentos das professoras da escola X, que inclusive parte delas fizeram ou fazem ainda cursos nestas faculdades particulares, alegam ser o tipo de faculdade mais acessível para as mesmas cursarem, pois não dispõem de muito tempo para estudarem.

É verídico que tais faculdades oferecem cursos aligeirados, com disciplinas resumidíssimas, o que gera questionamentos acerca da qualidade da formação do professor. Todavia, é fato que, a maioria dos professores precisa trabalhar às 40 horas, têm inúmeros afazeres além-escola, se verem precisando estudar, mas eis que surge a questão: em que tempo? Deste modo, se obrigam a se inscreverem nestas faculdades, pagando mensalidades altas, diante do salário que recebem, para se sentirem mais capacitadas e receberem um diploma que comprove sua formação inicial ou continuada. Contudo, a Lei exige a formação, porém, na prática, as condições de jornada de trabalho dos professores, torna-se quase inviável, que esta formação seja concretizada de forma qualitativa.

Há poucos anos, surgiu também na cidade de Limoeiro do Norte-CE, um programa de pós-graduação stricto sensu da UECE, nos campus da FAFIDAM e FECLESC, que é o MAIE - Mestrado Acadêmico Intercampi em Educação e Ensino, um mestrado público e gratuito. Então, mais uma forma de contribuir com a formação continuada dos professores. Mas o fator TEMPO, para estudar, se preparar para todas as fases da seleção, é um problema preocupante na rotina de trabalho dos professores da educação básica. Deste modo, observa-se um certo distanciamento entre o que está escrito na Lei e as possibilidades de concretização, pois se oferece cursos de formação continuada, mas o egresso dos professores da educação básica (especificamente os professores dos anos iniciais do ensino fundamental) nestes cursos, especialmente das universidades públicas, se torna quase impossível.

$O$ discurso frequente das professoras da escola $X$, é justamente que não têm condições de cursar um mestrado, pois não há tempo para se prepararem. Algumas até demonstram vontade de um dia cursar um mestrado, mas se percebe nas falas, algo que está muito distante, que talvez não se realize. Outras, já afirmam que não querem fazer nunca um mestrado, que vão "parar por aqui", explicitando que já basta o curso de graduação ou de especialização que fizeram, mas sempre enfatizando que é por questão de "tempo", o fato de nem se pensar em tentar. Embora em seu inciso II do artigo 67, a LDB garanta "o aperfeiçoamento profissional continuado, inclusive com licenciamento periódico remunerado para esse fim". (BRASIL, 1996, p. 39) 
Pensa-se que o conceito de educação continuada que se consta na Lei, deveria ser ampliado, ou seja, não se restringir somente a cursos de pós-graduação, mas ao acompanhamento dos professores em serviço. Formações que partissem do "chão da escola", das necessidades que os professores manifestam em seu dia a dia escolar, ao passo que partindo de reflexões que surgem a partir das práticas dos professores, houvessem discussões, tomadas de decisões, sendo os professores sujeitos ativos nesta formação continuada, formadores uns dos outros. Tais institutos poderiam ampliar suas funções, objetivando oferecer uma formação continuada de qualidade para os professores, de maneira que fossem sendo superadas as dificuldades que surgem-se no cotidiano da escola.

Já o PNE 2001-2011, surge num contexto considerado a “Década da Educação" (GHIRALDELLI Jr., 2009, p. 190). Na verdade, a ideia de se planejar e formular um Plano Nacional de Educação, advinha desde a época da primeira LDB, a Lei 4.024/61, todavia " Tal plano não tinha força de Lei. Além disso, foi várias vezes modificado durante a Ditadura Militar". (idem) Mas, com o fim da Ditadura Militar e com a criação da Constituição de 1988, retoma-se novamente a ideia de um Plano Nacional de Educação, o que a LDB, Lei 9394/96 veio a reforçar, incumbindo à União desta responsabilidade. Acontece que nesse período, o Brasil vivenciava o conturbado governo de Collor de Melo, que somente após o impeachment, tendo como presidente Itamar Franco, é que o Brasil tentou reerguer-se.

Inicialmente houve um evento em Jomtien, na Tailândia, conhecido como "Conferência Mundial de Educação para Todos", no ano de 1990, tendo como finalidade um documento que orientasse por quais caminhos a educação deveria caminhar, a fim de se superar da situação de analfabetismo enorme em que se encontrava o Brasil, dentre outros países e dentre outros problemas também que aconteciam neste período, no setor educacional.

Após esta Conferência, no Brasil houve diversos Encontros tratando da mesma temática, ou seja, das metas estabelecidas no documento final da Conferência Mundial de Educação Para Todos. No entanto, o que teria que ser feito para o alcance dessas metas, ficou a cargo do novo governo, liderado por Fernando Henrique Cardoso, que em resposta, surge de fato o PNE - Plano Nacional de Educação, que só vai ser publicado no ano de 2001, se prolongando até o ano de 2011.

Em 11 de fevereiro de 1998, o Poder Executivo enviou ao Congresso Nacional a mensagem 180/98, relativa ao projeto de lei que instituía o Plano Nacional de Educação. A sua tramitação começou pela Câmara dos Deputados como Projeto de Lei 4.173, de 1998, apensado ao PL 4.155/98, em 13 de março de 1998. Na exposição de Motivos o ministro da Educação destacou a concepção do Plano, que teve como eixos norteadores, do ponto de vista legal, a Constituição Federal de 1988, a Lei de Diretrizes e Bases da Educação Nacional, de 1996, e a Emenda Constitucional 14 de 1995, que instituiu o Fundo de Manutenção e Desenvolvimento do Ensino Fundamental e de Valorização do Magistério (FUNDEF). Considerou ainda realizações anteriores, principalmente o Plano Decenal de Educação para Todos, preparado de acordo com as recomendações da reunião organizada pela UNESCO e realizada em Jomtien, na Tailândia, em 1993. Além deste, os documentos resultantes de ampla mobilização regional e nacional que foram apresentados pelo Brasil nas conferências da UNESCO constituíram subsídios igualmente importantes para a preparação do documento. Várias entidades foram consultadas pelo MEC, destacando-se o Conselho Nacional de Secretários de Educação (CONSED) e a União Nacional dos Dirigentes Municipais de Educação (UNDIME). (GHIRALDELLI Jr., 2009, p. 193)

Uma das marcas do governo de Fernando Henrique foi o Boom de programas educacionais promovidos pelo governo, o que gerou uma explosão de tantos "que fazer", que se o intuito era melhorar a educação prioritariamente em qualidade, o contrário aconteceu, tudo aumentou em quantidade, mas a qualidade ainda ficou a desejar, embora tenham havido mudanças significativas.

Acerca da Formação Continuada dos professores, este PNE, traz algumas metas a serem atingidas com o prazo de dez anos. É notório o reconhecimento que o documento apresenta sobre a importância da formação dos professores, tanto inicial, quanto continuada, para que a qualidade do ensino, que é um dos pontos centrais deste PNE, seja melhorada.

Esforços dos sistemas de ensino e, especificamente, das instituições formadoras em qualificar e formar professores têm se tornado pouco eficazes para produzir a melhoria da qualidade do ensino por meio de formação inicial porque muitos 
professores se deparam com uma realidade muitas vezes desanimadora. (...) Formar mais e melhor os profissionais do magistério é apenas uma parte da tarefa. (...) É preciso que os professores possam vislumbrar perspectivas de crescimento profissional e de continuidade de seu processo de formação. Se, de um lado, há que se repensar a própria formação, em vista dos desafios presentes e das novas exigências no campo da educação, que exige profissionais cada vez mais qualificados e permanentemente atualizados, desde a educação infantil até a educação superior (e isso não é uma questão meramente técnica de oferta de maior número de cursos de formação inicial e de cursos de qualificação em serviço) por outro lado é fundamental manter na rede de ensino e com perspectivas de aperfeiçoamento constante os bons profissionais do magistério. (BRASIL, 2001, p. 143-144)

Se o centro do fazer pedagógico é o processo de ensino e aprendizagem, é pertinente e fundamental o investimento na formação dos professores, formação esta que esteja muito mais comprometida com a qualidade, e que esta formação qualitativa possa se estender a todos os professores, pois todos têm o direito de serem bem formados, já que são cobrados que se ensine com eficácia. No entanto, o professor que preza por sua formação, sabe-se responsável também pela mesma, ou seja, é dever do professor buscar ter uma formação sólida, para isso, busca-se ser sujeito ativo em sua auto formação, consciente de que sua profissão exige essa responsabilidade.

Como no próprio Plano Nacional de Educação, é esclarecido:

Assim, a valorização do magistério depende, pelo lado do Poder Público, da garantia de condições adequadas de formação, de trabalho e de remuneração e, pelo lado dos profissionais do magistério, do bom desempenho na atividade. Dessa forma, há que se prever na carreira sistemas de ingresso, promoção e afastamentos periódicos para estudos que levem em conta as condições de trabalho e de formação continuada e a avaliação do desempenho dos professores. (BRASIL, 2001, p. 149-150)

O PNE também garante que:

A formação continuada dos profissionais da educação pública deverá ser garantida pelas secretarias estaduais e municipais de educação, cuja atuação incluirá a coordenação, o financiamento e a manutenção dos programas como ação permanente e a busca de parceria com universidades e instituições de ensino superior. (BRASIL, 2001, p. 152)

Na cidade de Limoeiro do Norte-CE, as professoras da escola X relatam que de fato a Secretaria de Educação do município, oferece mensalmente estas formações, ministradas por técnicos de educação da própria Secretaria, exceto as "semanas pedagógicas" no início e no meio do ano, onde geralmente se contrata algum palestrante de outras cidades ou estados. No entanto, é geral nas falas das professoras, a demonstração de que são formações muitas vezes mecânicas, com assuntos distanciados das necessidades mais urgentes que se manifestam nas escolas, assim como, confessam serem formações um tanto cansativas, pois geralmente nesses encontros, os professores são seres passivos, que vão somente para absorver. Então se questiona: o que é mais importante: se oferecer todos os meses, formações desvinculadas das necessidades dos professores, mas está se oferecendo como diz a Lei? Ou, oferecer formações com o objetivo maior de provocar de fato mudanças na prática pedagógica e no processo de ensino e aprendizagem, e que os professores se sintam motivados para esse fim?

Partindo para o novo PNE 2014-2024, o qual consta muito das metas e objetivos do PNE 2001-2011, pelo fato de que boa parte não foi alcançada, analisa-se inicialmente o contexto em que o mesmo foi criado.

O PNE vigente foi encaminhado pelo governo Lula e sancionado pela atual representante da presidência do país, Dilma Rousself e se deu da seguinte forma:

O PNE foi enviado pelo Governo Federal à Câmara dos Deputados em 20 de dezembro de 2010, discutido ao longo do ano de 2011 com a sociedade civil, através de Audiências Públicas e Seminários Estaduais. Tramita nas Comissões de Constituição e Justiça e de Cidadania (CCJC), Finanças e Tributação (CFT), Educação e Cultura (CEC), Direitos Humanos e Minorias (CDHM), Seguridade Social e Família (CSSF) e Finanças e Tributação (CFT), e deverá ser votado neste ano de 2012. 0 relator do projeto é o deputado Angelo Vanhoni (PT-PR). Para 
vigorar o plano deve ser aprovado pela Câmara, pelo Senado e passar pela sanção presidencial. (AGLIARD, WELTER, PIEROSAN, 2012, p. 01)

Segundo Motta, Piccinini, Silva, Lamarão e Geraldo:

O Plano Nacional de Educação (PNE. Lei 13.005/2014), após quase quatro anos transitando no Congresso, foi celebrado pelo Ministério da Educação (MEC) como um documento que foi discutido e elaborado com ampla participação de organizações da sociedade civil, de entidades acadêmicas e sindicais e de representantes das redes federal, estaduais e municipais de ensino. A referida "ampla participação" deu-se por meio das CONAEs (Conferências Nacionais de Educação) no decorrer de 2009, culminando, em 2010, com a entrega do documento PNE-CONAE ao Ministério. (2015, p. 01 - 02)

O PNE é composto por vinte metas e 254 estratégias, as quais deverão ser postas em prática no período de dez anos, assim como no PNE passado. Destas metas e estratégias, algumas são destinadas à formação do professor. Neste sentido, destaca-se as que especificam a formação continuada, como elemento crucial na carreira docente. Das metas:

5.1) estruturar os processos pedagógicos de alfabetização, nos anos iniciais do ensino fundamental, articulando-os com as estratégias desenvolvidas na préescola, com qualificação e valorização dos (as) professores (as) alfabetizadores e com apoio pedagógico específico, a fim de garantir a alfabetização plena de todas as crianças; 5.6) promover e estimular a formação inicial e continuada de professores (as) para a alfabetização de crianças, com o conhecimento de novas tecnologias educacionais e práticas pedagógicas inovadoras, estimulando a articulação entre programas de pós - graduação stricto sensu e ações de formação continuada de professores (as) para a alfabetização; Meta 16: formar, em nível de pós-graduação, 50\% (cinquenta por cento) dos professores da educação básica, até o último ano de vigência deste PNE, e garantir a todos (as) os (as) profissionais da educação básica formação continuada em sua área de atuação, considerando as necessidades, demandas e contextualizações dos sistemas de ensino. (BRASIL, 2011, p. 17)

Nota-se grandes desafios acerca da formação dos professores da educação básica propostos no PNE atual, e em algumas regiões se imagina as dificuldades de serem colocados em prática. Na referida escola pública de Limoeiro do Norte-CE, não se concretiza esse apoio pedagógico específico aos professores alfabetizadores, exceto algumas formações que acontecem sobre o PAIC (Programa de Alfabetização na Idade Certa). E os processos pedagógicos de alfabetização que prevalecem na escola se dão com estratégias em sua maioria tradicionais, o que contribuem para que a aquisição da escrita e da leitura se realize de forma mecânica, consequentemente não prazerosa. Contrariando o que o PNE propõe sobre as novas tecnologias e práticas pedagógicas inovadoras. A articulação entre programas de pós-graduação stricto sensu e ações de formação continuada com professores alfabetizadores, também não se concretiza nesta escola, e em praticamente nenhuma da cidade de Limoeiro do Norte-Ce.

Em relação à meta 16, há muito ainda o que se fazer, como já fora discutido anteriormente sobre a pósgraduação, no que diz respeito ao tempo restrito dos professores para estudarem. Nas pós-graduações lato sensu se torna mais fácil atingir tal meta, inclusive na escola X, tem algumas professoras especialistas, embora todas em faculdades particulares. Porém, no tocante as pós-graduações stricto sensu, há um obstáculo muito grande a ser saltado, por questões já tratadas neste texto.

Deste modo, percebe-se que embora haja certa obediência às Leis, e esforços em cumpri-las, há ainda certa desconexão entre o que se está escrito nas mesmas, com o se concretiza de fato, especialmente em regiões mais pobres do país, onde o descaso com a educação é maior, especificamente nos interiores dos estados, onde se revelam realidades e problemas diversos, tais como: seca, fome, pobreza, miséria, desemprego, falta de moradia, de saneamento básico, entre tantos outros; que interferem diretamente no setor educacional. 


\section{RESULTADOS E DISCUSSÃO}

Diante do estudo realizado para esta pesquisa, encontra-se os seguintes resultados:

Certo distanciamento entre teoria e prática, inclusive nos documentos que regem a educação do nosso país;

Estados e/ou cidades menos favorecidas, sofrem impactos maiores no que se refere à concretização das políticas públicas educacionais;

Professores se obrigam a trabalhar dois ou três expedientes para a sua sobrevivência, ficando restrito o tempo para dedicar-se aos estudos para uma formação continuada;

Por outro lado, professores demonstram cansaço e desmotivação para darem continuidade aos estudos para a qualificação de suas formações;

Professores se limitam às formações oferecidas pela Secretaria Municipal de Educação, de certo modo, por terem obrigatoriedade de participarem;

As formações da Secretaria Municipal de Educação pouco inovam em novas práticas, em assuntos mais necessários, tornando estas formações mecânicas e cansativas, por colocarem os professores simplesmente, em sua maioria, como seres passivos, ouvintes.

\section{CONSIDERAÇÕES FINAIS}

Diante de toda a discussão que o texto propõe, conclui-se que nas Legislações analisadas, acerca da formação continuada dos professores, há intenções bastante positivas e necessárias, ou seja, na teoria estas Leis são muito bem formuladas, no entanto, se percebe certo distanciamento em relação ao que é praticado, ao que é concretizado. Para que se atinjam tais objetivos, metas, estratégias, é preciso criar condições para isso, o que no Brasil, mais especificamente nos interiores, isso não acontece, o descaso ainda é presente.

Sabe-se da importância que tem a formação continuada dos professores, como condição crucial para que o processo de ensino e aprendizagem aconteça de forma significativa, inclusive nas Leis constam tal importância, todavia, o que se propõe é uma coisa, e o que se faz para que estas propostas se concretizem é outra, justamente o que está em falta no nosso país.

Diante do exposto, pensa-se que somente quando a educação de qualidade for prioridade nos governos brasileiros, é que de fato ver-se-á a teoria sendo praticada e refletida, se concretizando deste modo a práxis educacional, sendo sujeitos ativos, alunos e professores, nas escolas deste Brasil, país tão rico em teoria, mas ainda tão precário em ações.

\section{REFERÊNCIAS}

[1] Brasil. Lei 10.172, de 9 de janeiro de 2001. Aprova o Plano Nacional de Educação e dá outras providencias. Diário Oficial da União. Brasília, DF, 10 jan. 2001.

[2] __. Lei de Diretrizes e Bases da Educação Nacional: Lei n 9.394, de 1996, que estabelece as diretrizes e bases da educação nacional, e legislação correlata. 4⿳亠丷a Ed. Brasília: Câmara dos Deputados, Coordenação de Publicações, 2007.

[3] __. Poder Executivo. Projeto de Lei no 8.035, de 20 de dezembro de 2010. Aprova o Plano Nacional de Educação para o decênio 2011-2020, e dá outras providências. Câmara dos Deputados, Brasília, 2010.

[4] Ghiraldelli Junior, Paulo. História da educação brasileira. 4. ed. São Paulo: Cortez, 2009.

[5] Agliard, Délcio Antônio; Welter, Cristiane Backes; Pierosan, Maristela Rates. O novo Plano Nacional Decenal de Educação e as políticas educacionais de estado: velhas metas novos desafios. In: IX Seminário de Pesquisa em Educação da Região Sul - Anped. 2012, São Paulo. Anais... São Paulo, SP, Brasil: UCS, 2012. 18 p. Disponível em: http://www.ucs.br/etc/conferencias/index.php/anpedsul/9anpedsul/paper/viewFile/3210/178. Acesso em: 28 de fevereiro de 2016.

[6] Motta, Vânia Cardoso da; Piccinini, Cláudia Lino; Silva, Simone Maria; Lamarão, Marco Vinícius Moreira; Geraldo, Débora Sabina da Silva. Plano Nacional de Educação 2014: notas críticas. In: VII Jornada Internacional Políticas públicas. 2013. Maranhão. Anais... Maranhão, MA, Brasil: Ufma, 2013. 52 p. Disponível em: http://www.joinpp.ufma.br/jornadas/joinpp2015/pdfs/mesas/plano-nacional-de-educacao-2014_notas-criticas.pdf. Acesso em: 01 de março de 2016. 


\section{Capítulo 15}

\section{Formação continuada de professores: Um investimento necessário}

\section{Adriétt de Luna Silvino Marinho}

Tamires Cristina Ribeiro Silva

Resumo: 0 presente trabalho busca analisar a contribuição da formação continuada dos professores no que se refere à aquisição de uma base de conhecimentos para sua prática pedagógica. Tendo em vista que a prática do professor consiste numa ação complexa e multifacetada, sua formação também se configura em algo desafiador, pois esta formação não se conclui na formação inicial, ela perpassa uma trajetória que refaz e se reavalia na construção do seu saber docente. Assim, a presente pesquisa aborda, sob a ótica de diferentes autores, a importância da valorização do professor, na ideia de aprendizagem como construção de conhecimentos a partir dos encontros formativos dos docentes da Rede Municipal de Moreno/PE. A partir das respostas dos professores a respeito do ciclo de formações, a análise dos dados permite uma reflexão sobre o espaço da formação do professor no mundo contemporâneo, que é desafiador e complexo, requerendo constante evolução.

Palavras-chave: Formação de professores, Formação continuada, Prática docente. 


\section{INTRODUÇÃO}

Manter-se informado, nos dias atuais, torna-se uma necessidade urgente e indispensável para qualquer profissional. Mas não se tratam apenas de notícias sobre o mundo atual, é fundamental que se busque uma informação atrelada a um sentido real e útil, passando de uma mera informação para um conhecimento construído e adquirido.

No que tange a esse objetivo, a formação continuada de professores emerge como ponto fundamental para a ressignificação da prática docente e da aprimoração dos conhecimentos adquiridos na formação de base do profissional da educação, uma vez que os cursos de licenciatura são considerados insuficientes diante das demandas cotidianas que a prática docente requer.

Tardif (2002, p.57) salienta que se o trabalho modifica o trabalhador e sua identidade, modifica também, como o passar do tempo, o seu "saber trabalhar". A esse respeito, França (2018) afirma que a formação continuada tem sido entendida como um processo permanente e constante de aperfeiçoamento dos saberes necessários à atividade dos educadores. Ela é realizada após a formação inicial e tem como objetivo assegurar um ensino de qualidade cada vez maior aos alunos.

0 termo em si sugere uma atividade que é contínua e que se refaz, tendo em vista as transformações sociais, políticas, econômicas, educacionais e as necessidades formativas dos professores nesse contexto (ALMEIDA, 2015).

Tal prática sugere e almeja que a prática docente seja revisitada periodicamente e que se promova um trabalho cujo processo de realização desencadeia uma transformação real no trabalhador (TARDIF, 2002, p.56).

Diante disso, a Rede Municipal de Moreno tem buscado novos caminhos para formação continuada de seus docentes.

A princípio, diante das mudanças curriculares propostas pela Base Nacional Comum Curricular, sentiu-se a necessidade de aprofundar o debate sobre o tema "currículo" entre os professores da rede a fim de instrumentalizar o professor com um aporte teórico, dando-lhe condições de esclarecer suas dúvidas, emitir suas opiniões e contribuir com a construção da proposta curricular do município, sendo esta uma releitura do Currículo do Estado de Pernambuco.

Visando uma formação que seja, ao mesmo tempo, polivalente e diversificada, como aponta Gatti (2009, p.94), além da discussão sobre o Currículo do Estado com o grupo de professores de cada ano escolar, por componente curricular, apresentaram-se, ainda, possibilidades de como trabalhar os conteúdos curriculares por meio de diferentes estratégias metodológicas, facilitando o processo de ensinoaprendizagem. Como ponto de partida, considerou-se ainda a autonomia do professor e sua participação nas formas colaborativas de aprendizagem (GADOTTI, 2011, p.69).

Essa reconfiguração do sistema de formações continuadas da rede de ensino municipal justifica-se por uma preocupação com a qualidade do ensino ofertado aos alunos e com o bem estar do professor, que, ao reafirmar suas convicções teóricas e aprimorar seus conhecimentos, torna-se mais seguro e autônomo na execução da sua prática docente. Antes de tudo, é preciso compreender que o professor é sujeito nesse processo (FREITAS \& PACÍFICO, 2015).

Esta experiência vivenciada torna-se, então, o objeto de estudo deste artigo. Metodologicamente, este artigo será composto de duas partes: uma na qual será feita uma reflexão sobre a formação de professores e seu aprimoramento através da formação continuada e outra composta pelo relato das experiências vivenciadas no primeiro ciclo de formações de 2019, cuja temática abordada foi o currículo de Pernambuco, e seus resultados analisados à luz de referenciais teóricos da área.

Diante do exposto, o objetivo geral dessa pesquisa é discutir sobre a formação continuada de professores e sobre as limitações que a formação inicial apresenta.

Para isso, alguns objetivos específicos são fundamentais: examinar as atuais perspectivas da pesquisa na área da formação de professores e suas possibilidades na profissionalização do professor; identificar os saberes necessários para uma prática pedagógica eficaz; discutir a relevância do espaço de diálogos e troca de experiências de entre os profissionais da educação como promotor da autorreflexão e do aprimoramento docentes. 


\section{METODOLOGIA}

A metodologia deste artigo é de abordagem quali-quantitativa e de natureza empírica, cujo desenvolvimento da prática e das ações de formação continuada configuram-se como objeto de estudo. Foram realizadas formações nas áreras de: Linguagens, Matemática, Ciências da Natureza e Ciências Humanas para os professores de cada ano escolar. As aulas formativas forma ministradas pela equipe técnica da Secretaria de Educação, com professores especialistas em cada campo do conhecimento. Neste artigo, analisamos as respostas dos professores sobre a formação da Área de Linguagens, como um recorte que servirá como uma amostra populacional.

Os encontros tiveram o objetivo de estudar o Currículo do Estado (que fora elaborado à luz da Base Nacional Comum Curricular - BNCC) e adaptá-lo à realidade da Rede de Moreno com a colaboraão de todos os professores. Os docentes, após o estudo da parte teórica, foram convidados a elaborar, em pequenos grupos, uma proposta de planejamento anual (bimestre a bimestre) com as habilidades que eles mesmos julgavam adequadas para cada unidade didática. Os formadores também direcionavam a discussão para a realidade da sala de aula, dando exemplos práticos e sugestões de atividades que contemplassem cada habilidade elencada.

Os dados foram coletados à medida que as formações ocorriam, através de fichas de avaliação preenchidas pelos docentes ao término de cada encontro formativo, essas fichas era compostas de duas perguntas básicas: 1) Como você avalia este encontro de formação?, 2) Os conhecimentos adquiridos foram relevantes para a sua prática profissional?. Também foram considerados relatos dos decentes nos círculos de conversas que foram realizados em cada encontro, nos quais os profesosres poderiam emitir opiniões, sugestões e tirar dúvidas

Os resultados foram sistematizados em gráficos para uma melhor leitura e interpretação dos mesmos e analisados à luz do referencial teórico da área.

\section{DESENVOLVIMENTO}

Ensinar é uma atividade dinâmica e altamente desafiadora, pois a ação docente se desenvolve em meio aos múltiplos papéis que lhe são cabíveis. A profissão docente, nesse contexto, exige do (a) professor (a) um constante repensar de seu fazer pedagógico, o que pode acontecer de maneira consciente, desejada ou não (PEREIRA, 2011, p. 36). Esse repensar pedagógico exige do professor o domínio de conhecimentos específicos que viabilizam uma prática pedagógica com maior qualidade.

Neste sentido, a formação de professores vem sendo foco de análise por vários estudos e pesquisas nas últimas décadas. "O debate em torno do professorado é um dos pólos de referência do pensamento sobre a educação, objeto obrigatório da investigação educativa e pedra angular dos processos de reforma dos sistemas educativos" (SACRISTÁN, 1999, p.64).

A formação continuada está diretamente ligada ao papel do professor: possibilitando transformações de suas práticas pedagógicas e nas possíveis mudanças do contexto escolar.

Zeichner, em entrevista concedida em 2014, trata de temas importantes que estão no bojo da discussão atual sobre a formação de professores. Nesse sentido, ele afirma: Eu acho que precisamos fortalecer o ensino público não só considerando-o um bem privado para beneficiar crianças individualmente, mas como um bem público para beneficiar a sociedade como um todo e reconhecer realmente o seu valor (ZEICHNER, SAUL E DINIZ-PEREIRA, 2014, p. 2217).

Por esse motivo, a Rede de Ensino de Moreno entende que a formação de professores tem uma grande importância para o desenvolvimento das habilidades do profissional, realizando um elo entre a teoria e a prática educativa. E, ao mesmo tempo, exige uma mudança conceitual e comportamental de práticas educativas.

Imbernón (2010) ainda ressalta a formação continuada como fomento de desenvolvimento pessoal, profissional e institucional dos professores, elevando seu trabalho para transformação de uma prática. Tal prática está para além das atualizações científicas, didáticas ou pedagógicas do trabalho docente, supõe uma prática cujo alicerce é balizado na teoria e na reflexão desta para mudança e transformação no contexto escolar.

Assim, a formação continuada contribui de forma significativa para o desenvolvimento do conhecimento profissional do professor, cujo objetivo, dentre outros, é facilitar as capacidades reflexivas sobre a própria prática docente elevando-a a uma consciência coletiva. A partir dessa perspectiva, a formação continuada 
conquista espaço privilegiado por permitir a aproximação entre os processos de mudança que se deseja fomentar no contexto da escola e a reflexão intencional sobre as consequências destas mudanças.

Nesse contexto, valorizar a formação docente é valorizar o ensino por excelência. Os estudos de Nóvoa (1999) defendem que a formação docente é um processo interativo, por meio do qual se tornam um espaço de formação mútua, de afirmação de valores da profissão, propiciando um conhecimento profissional compartilhado, que unindo a prática a discussões teóricas, gera novos conceitos.

\section{RESULTADOS E DISCUSSÃO}

Após o ciclo de formações do mês de junho, a equipe técnica da Secretaria de Educação analisou e sistematizou os dados obtidios atraves da ficha de avaliação que os professores preencheram ao término dos encontros. Além das fichas, foram consideradas as falas dos docentes a respeito dos encontros.

As analises foram realizadas à luz de alguns referenciais teóricos fundamentais para os estudos sobre formação de professores: Tardif (2002), Almeida (2015), Gatti (2009), Gadotti (2011), Zeichner (2008), dentre outros.

Muitos professores relatam que, embora tenham tido boa formação de base, muitas vezes sentem-se desmotivados em sua prática, pois não conseguem manter seus alunos concentrados nas aulas e nem despertar a curiosidade deles (RODRIGUES, LIMA \& VIANA, 2017).

Foi na tentativa de diminuir a distância entre o saber científico e o saber fazer do professor, que a ação interventora na Rede Municipal de Ensino iniciou pelo ciclo de formações continuadas para os professores dos Anos Iniciais do Ensino Fundamental.

O processo de formação continuada de professores se torna uma importante estratégia para contribuir com o sucesso escolar e oportuniza aprendizados referentes às metodologias utilizadas no cotidiano do docente em sala de aula. Diante disso, os professores buscam, cada vez mais, oportunidades de novas estratégias de ensino e de acompanhamento das ações pedagógicas.

Nesse sentido, Zeichner (2008) considera que muita coisa aconteceu no campo da educação e levou a uma mudança de foco na formação docente: de uma visão de mero treinamento de professores para uma mais ampla, que envolve a compreensão das diferentes práticas e que ajude os professores a desenvolverem autonomia para tomar decisões sábias sobre o que fazer. Segundo o autor, os professores precisam delimitar objetivos bastante específicos para o desenvolvimento da sua prática dentro do contexto em que trabalham e levando em consideração as necessidades de aprendizagem de seus alunos.

Seguindo essa linha de reflexão sobre a prática pedagógica e sobre a construção conjunta de saberes realmente úteis ao profissional professor, foram realizadas duas perguntas básicas para os professores ao término dos encontros realizados no mês de junho, cuja temática abordada foi "O currículo de Pernambuco - Área de Linguagens", com os grupos de professores de cada ano escolar: 1) Como você avalia este encontro de formação? 2) Os conhecimentos adquiridos serão úteis ao exercício de sua profissão.

Nos encontros formativos foram realizadas dinâmicas reflexivas, que estimulavam o grupo a falar e a interagir. Também foram selecionadas leituras deleite, cujo foco eram as relações interpessoais e o trabalho em equipe. Em seguida, foram feitas explanações teóricas, sobre as bases de sustentação do currículo e de autores da are de linguagens. Os professores intervinham sempre que tinha dúvidas ou queriam compartilhar exemplos práticos de suas aulas. No segundo momento, foram divididos pequenos grupos cuja tarefa era analisar o currículo anual do Estado de Pernambuco e elencar os objetos de conhecimento que caberiam em cada unidade didática.

Os resultados sugerem que os caminhos percorridos foram promissores e que a valorização docente tem sua materialização na forma como o professor é acolhido e em como o currículo e a teoria são apresentados dentro de uma perspectiva funcional.

A Tabela 1 apresenta os resultados obtidos para a primeira pergunta: 
Tabela 1: Como você avalia este encontro de formação?

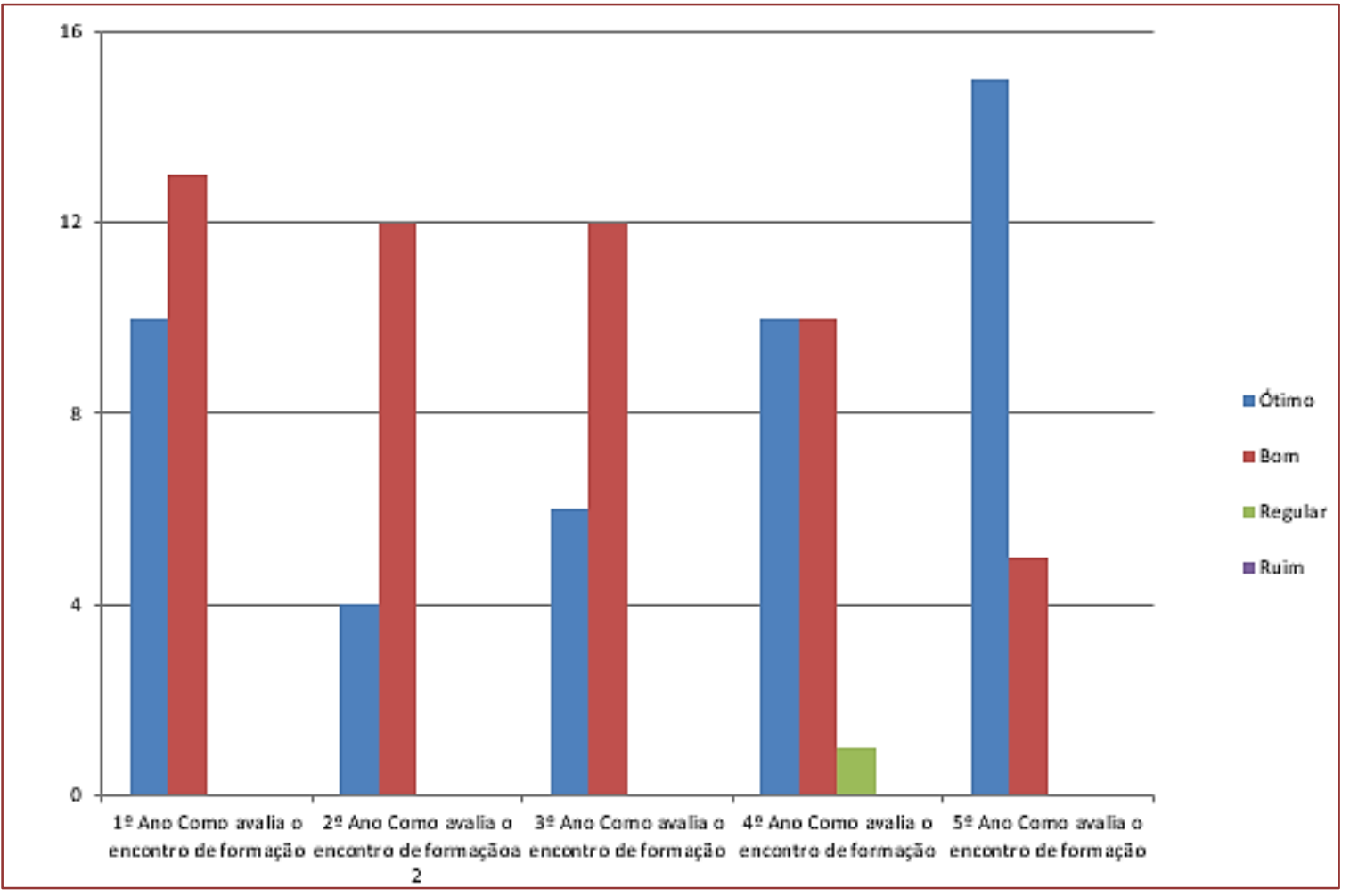

Como se pode constatar, nenhum professor considerou este encontro ruim, o que aponta pistas sobre o bem estar do professor durante o seu momento de formação. Houve tempos em que os professores queixavam-se frequentemente dos encontros, considerando-os enfadonhos ou desmotivantes, além disso, havia um grande desconforto com relação ao espaço em que as formações ocorreram em momentos anteriores.

Após essa nova perspectiva de trabalho, buscou-se não apenas aproximar o profissional professor do desenvolvimento das ações formativas, como também propiciar um espaço acolhedor, por este motivo, tornam-se muito valiosas as avaliações do professor e relatos como o que podemos ler a seguir: "O local é muito bom, adequado para formações" (Professora do 2ํAno).

Percebe-se, assim, que a escolha do local para uma formação de professores tem um papel fundamental, pois o ambiente pode revelar acolhimento ou distanciamento, pode atrair ou repelir.

Também é fundamental investir em recursos diferenciados de sua rotina, como dinâmicas, leituras deleite, e, sobretudo, garantir o espaço do diálogo, da troca de experiências e do conhecimento teórico, esses fatores exercem grande influência no desenvolvimento, na participação e no aprendizado, pois influenciam a busca de novas estratégias metodológicas.

Analisando a Tabela 1, pode-se observar que 53\% dos professores consideram o encontro formativo bom e $46 \%$ ótimo, apena 1\% dos profissionais considerou que o encontro foi regular, no entanto, não justificou tal avaliação. Estes dados apontam para uma formação com sentido real para o docente e que vem somar aos seus saberes práticos um saber teórico e instrumental. É sobre este aspecto que a pergunta número 2 questionava ao professor se os conhecimentos adquiridos forma úteis à sua prática profissional.

A Tabela 2 sistematiza as respostas de cada grupo de professores. 
Tabela 2: Os conhecimentos adquiridos serão úteis ao exercício de sua profissão?

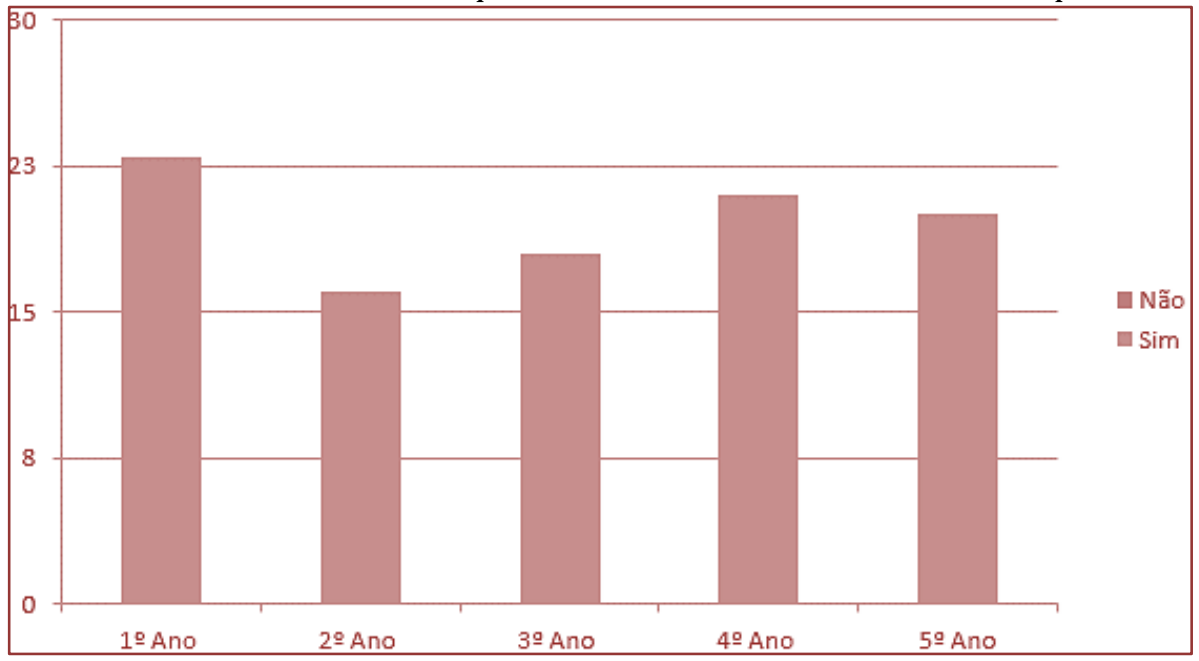

Conforme vemos na Tabela 2, $100 \%$ dos professores de todos os grupos consideraram que os conhecimentos foram úteis à sua prática.

Além dos dados coletados através da ficha de avaliação preenchida pelos professores no final dos encontros, alguns deles trouxeram relatos significativos a respeito desse momento de formação, como a professora X, que leciona no 4ํㅡ ano, e afirmou: "A formadora é muito boa, domina o conteúdo", da mesa forma, o professor Y, que atua no 5ㅇ ano, declarou: "A formadora usa uma linguagem clara, objetiva, conduz com louvor as discussões". Muitos professores também se manifestaram em torno da continuidade dos ciclos: "Os temas abordados são muito bons, é só seguir em frente que dará tudo certo!" (Professora Z, atua no $1^{\mathrm{o}}$ ano).

Neste sentido, o ciclo de formação continuada da rede municipal de Moreno (PE) aponta o início de um caminho que se deve trilhar, ampliando conhecimentos e reformulando o trabalho docente.

\section{CONSIDERAÇÕES FINAIS}

Todos os dias, o professor enfrenta vários desafios no desenvolvimento de sua prática. Por esse motivo, esse profissional é um dos poucos que, cotidianamente, precisa rever seu planejamento e refletir sobre seus próprios conhecimentos, pois, todos os dias o saber docente é confrontado por novos desafios. Essa é uma atividade que exige conhecimento teórico, experiência prática e reflexão.

Certamente, muito já se estudou a respeito da formação docente inicial ou de base e constatou-se em muitos estudos a ineficiência dos cursos de graduação como único momento formativo na vida de um professor (elencar pesquisas...)

Nesse contexto, a formação docente deve ser contínua, iniciando nos cursos de graduação e se estendendo a outros espaços formativos, tanto acadêmicos (especialização estricto e latto senso), além de palestras, congressos e eventos promovidos pela comunidade científica, mas também, e de modo muito especial, as formações promovidas pelos municípios, uma vez que estas estão trabalhando diretamente com o contexto em que o professor está inserido e pode alcançar especificidades da sala de aula dos professores de modo direto, além de favorecer que o professor tenha, em seu local de trabalho, um espaço garantido para o estudo teórico atrelado à reflexão sobre sua prática.

Nessa perspectiva, o professor passa a ser também pesquisador de sua ação docente para que possa crescer em sua vida profissional e desenvolver o processo de ensino/aprendizagem de forma autônoma, crítica e reflexiva, construindo o currículo em parceria com os seus colegas e ao mesmo tempo dialogando com a teoria e com as experiências práticas. 


\section{REFERÊNCIAS}

[1] Almeida, Marli Silva. Reflexões sobre a formação continuada em serviço de professores do ensino Disponível

em: http://nead.uesc.br/jornaped/anais_2015/formacao_de_professores_e_profissionalizacao_docente/Reflexoes_sobre_a _Formacao_Continuada_em_Servico_de_Professores_do_Ensino_Fundamental.pdf , acesso em 25/06/2019.

[2] Delors, J. Educação: um tesouro a descobrir. 2ed. São Paulo: Cortez . Os 4 pilares da Educação. Brasília, DF: Mec/Unesco, 2003.

[3] França, Luísa. A formação continuada e a sua importância para manter o corpo docente atualizado. Disponível em: https://www.somospar.com.br/a-formacao-continuada-e-a-sua-importancia-para-manter-o-corpodocente-atualizado/, acesso em 25/06/2019.

[4] Freitas, Sirley Leite \& Pacífico, Juracy Machado. Formação docente e os saberes necessários à prática pedagógica. Educa, Porto Velho (RO), v.2, n.4, pp. 1-17, 2015. ISSN 2359-2087

[5] Gadotti, M. Boniteza de um sonho: ensinar-e-aprender com sentido. 2. ed. São Paulo: Instituto Paulo Freire, 2011.

[6] Gatti, B. A. Formação de professores: condições e problemas atuais. Revista Brasileira de Formação de Professores, Cristalina, v. 1, n. 1, p. 90-102, maio 2009.

[7] Imbernón, F. Formação continuada de professores. Porto Alegre: Artmed, 2010.

[8] Novoa, A. Profissão professor. Portugal: Porto, 1999.

[9] Pereira, C. J. T. A Formação do Professor Alfabetizador: desafios e possibilidades na construção da prática docente. 2011. Dissertação (Mestrado em Educação) - Fundação Universidade Federal de Rondônia. Porto Velho, R0, 2011. Disponível em:

http://www.ppge.unir.br/uploads/62248421/arquivos/Disserta____CL_Udia_Justus_T_Rres_Pereira_520926749.p df, acesso em: 12/08/2019

[10] Rodrigues, P. M. L; Lima, W.S.R \& Viana, M.A.P. A importância da formação continuada de professores da educação básica: a arte de ensinar e o fazer cotidiano. V. 03. N. 01, setembro de 2017. ISSN25254227 Disponível em: http://www.maceio.al.gov.br/wp-content/uploads/2017/09/pdf/2017/09/3-A-Import\%C3\%82ncia-da-

Forma\%C3\%87\%C3\%830-Continuada-de-Professores-da-Educa\%C3\%87\%C3\%830-B\%C3\%81sica-a-Arte-deEnsinar-e-o-Fazer-Cotidiano-ID.pdf, acesso em: 13/08/2019.

[11] Sacristán, J.G. Poderes instáveis em educação. Porto Alegre: Artmed, 1999.

[12] Tardif, Maurice. Saberes docentes e formação profissional. Petrópolis, RJ: Vozes, 2002.

[13] Zeichner, Kenneth M. \& Saul, Alexandre. Pesquisar e transformar a prática educativa: mudando as perguntas da formação de professores - uma entrevista com kenneth m. zeichner. v. 12, n. 3 (2014) Revista e-Curriculum, São Paulo, v. 12, n. 03 p. 2211 - 2224 out./dez. 2014 ISSN: 1809-3876 2213 Programa de Pós-graduação Educação: Currículo - PUC/SP https://revistas.pucsp.br/curriculum/article/view/21405/15931, acesso em 18/07/2019

[14] Zeichner, Kenneth M. Uma análise crítica sobre a "reflexão" como conceito estruturante na formação docente. Educ. Soc., Campinas, vol. 29, n. 103, p. 535-554, maio/ago. 2008535 Disponível em http://www.scielo.br/pdf/es/v29n103/12.pdf, acesso em 18/07/2019 


\section{Capítulo 16}

Formação de professores e as Leis 10639/03 e 11.645/08: A concepção societária e o fazer didático

\section{Eliana Carmem da Silva}

Resumo: 0 ideal historicamente concebido na construção do Brasil tem evidenciado a prevalência de uma sociedade que se baseia na manutenção do status quo daqueles que a colonizaram desde os anos de 1500. A construção social das raças, utilizando a concepção sociológica, no Brasil, traz consigo um viés de discriminação que impacta marcadamente na vida da população negra no país. Como a educação formal se constitui elemento importante para a sua formação ideológica, surge a urgência de utilizá-la como mecanismo de quebra de estereótipos. A partir de estudos teóricos sobre a condição da população negra no Brasil desde o início da sua colonização e do diálogo com os professores do Curso Normal,este artigo investiga como tem se dado o ensino obrigatório da História da África e seus descendentes no país, através da Lei 10.639/2003 assim como a implementação da Lei 11.645/08, que acrescenta a primeira a obrigatoriedade da inserção da história dos povos indígenas. A metodologia aqui utilizada leva em conta, em seu primeiro momento, o levantamento das teorias que explicam raça e racismo e o ensino multicultural na Educação Brasileira. No segundo momento, vale-se da aplicação de questionário e análise obtida a partir dos dados coletados em pesquisa qualitativa, sobre a análise de conteúdo, com os regentes do Curso Normal do Instituto de Educação Professor Manuel Marinho, em Volta Redonda, estado do Rio de Janeiro.

Palavras-chave: Educação, Curso Normal, Lei 10.639/03, Racismo. 


\section{INTRODUÇÃO}

A perspectiva em realizar este estudo, tem como interesse principal, apontar qual a percepção dos docentes do Curso Normal, especificamente no Curso de Magistério de Nível Médio, oferecido pelo Instituto de Educação Professor Manuel Marinho, em relação a oferta obrigatória das Leis 10.639/03 e $11.645 / 08$.

A lei 10.639/03 é um dos principais marcos de conquista de direitos da comunidade negra no Brasil, que reivindica a inserção do protagonismo negro na constituição da história do país, contada até há pouco tempo, exclusivamente, a partir do olhar branco-europeu. Omitir a história afro-brasileira configura umas das estratégias mais eficazes na manutenção do status quo da classe dominante, desde a colonização, ratificado na constituição da sociedade brasileira capitalista, pós-escravidão. No início, a omissão representa o desejo da eliminação do negro da sociedade, sem uma política pós-abolição que atenda às pessoas escravizadas. Estas não possuem, em sua maioria, fonte de renda, seus laços e parentescos são extintos pelo processo escravizador, sendo descartadas pelo novo sistema, que depende de pessoas civilmente livres para que haja consumo. Somando-se a esta condição, cientistas racialistas, segundo Dantas (2013), constroem teorias para justificar o embranquecimento da sociedade. A partir da década de 1930, com a idéia de uma democracia racial, difundida principalmente pela obra Casa Grande \& Senzala de Gilberto Freyre (2003), o interesse é o de manter a posição do negro e das demais etnias nos espaços determinados pela classe dominante:

A pesquisa de cunho qualitativo, com narrativas, pretende sondar em que medida os profissionais responsáveis pela formação de professores inserem a educação para equidade étnico-racial em seu fazer profissional.

\section{METODOLOGIA}

A metodologia utilizada neste artigo apresenta duas fases: a primeira com pesquisa teórica, levantamento bibliográfico de autores que antecederam os estudos a respeito da questão das relações étnico-raciais na educação, seguida de leitura e fichamento. Após esta etapa, aplica-se questionário semi-estruturado e contendo perguntas fechadas e abertas, a pesquisa se torna uma pesquisa de campo, vivenciada na pesquisa-ativa, pois seus apontamentos incidem no fazer profissional.

Por ser uma pesquisa na educação, considera-se que nesta área o objeto tem a ver com envolvimento dos professores na solução de uma problemática que diz respeito ao seu campo de atuação e, desta forma, tem o sentido de avaliar os entraves que se apresentam para a realização da obrigatoriedade da lei.

Histórias de vida são elementos importantes para o entendimento da prática profissional e sua utilização traz possibilidade de avaliação qualitativa. 0 método utilizado tem a pretensão de utilizar a pesquisa estratégica para a proposição de mudança nas ações pedagógicas dos professores regentes no Instituto de Educação.

Minayo (2009, p.63 apud Malinowski, 1984, p. 37) escreve:

“Na pesquisa qualitativa, a interação entre o pesquisador e os sujeitos pesquisados é essencial. Todo o empenho é investido para que o corpo e o sangue da vida real componham o esqueleto das construções abstratas" Minayo (2009, apud Malinowski)

Com tais perguntas tivemos o intuito de realizar um levantamento do perfil dos entrevistados, todos professores regentes da instituição e seu conhecimento da lei em discussão neste trabalho.

O questionário levantou as seguintes questões:

Perfil

\subsection{DO GÊNERO:}

Por tratar-se de uma pesquisa com fundamento sociológico, optou-se pela categoria gênero. Segundo Carvalho (1999): "Pensar a categoria gênero nos dá a possibilidade de entender as relações entre os sexos também no âmbito da cultura, do simbólico, das representações e isso é muito importante quando se pensa em educação [...]" (Carvalho, 1999, p.9). 


\subsection{DA COR:}

Para o levantamento da cor dos entrevistados, optamos pela categorização do Instituto Brasileiro de Geografia e Estatísticas (IBGE), tendo em vista a complexidade de análise, de dados abertos, em uma estrutura de artigos.

Do Tempo de Formação e Do tempo que leciona no curso normal e Sobre o conhecimento da legislação:

A questão do tempo de formação foi pensada sobre a obrigatoriedade dos estudos multiculturais a partir da Constituição Federal do ano de 1988. Entende-se a lógica de que se a formação ocorreu antes deste período, vem de uma dinâmica de educação que não a privilegiava. Tornava-se, portanto, obrigatório o ensino de outras culturas, além da dominante. A mesma lógica ocorre para a sua obrigatoriedade em ensinar; se o profissional busca a formação continuada, entende-se que este tenha conhecimento de sua necessidade em aplicá-la.

\subsection{SOBRE AS DISCIPLINAS QUE LECIONAM:}

Há, no senso comum, a percepção de que a lei 10.639/03 trata apenas da aplicação em disciplinas como História, Arte e Sociologia, entretanto, pensar a interdisciplinaridade na práxis pedagógica, assim como conhecer as demais culturas são fundamentais para esta prática. Inserimos este quesito com a intenção de compreender de que forma a percepção do senso comum atinge o fazer dos profissionais entrevistados.

As duas últimas questões foram perguntas abertas; a primeira seria a resposta sobre em que momento reconhecem aplicar as leis em questão e a segunda solicitava aos professores que respondessem quais lembranças tinham de formação que tratasse da diversidade étnico-racial.

\section{DESENVOLVIMENTO}

Para nortear este trabalho, foi utilizado termo raça em uma concepção sociológica, entendendo-o como um fenômeno social, construído sócio-histórico-culturalmente, já que biologicamente o termo foi superado, levando em consideração que seria incoerente tomar como parâmetro a questão de cor da pele para diversificar a espécie humana. Portanto, sociologicamente é o modo que nos permitirá compreender como se constrói o racismo e as suas diversas expressões e como essas expressões se dão por vários condicionantes, relativos às relações estabelecidas no decorrer da história humana.

Munanga (2013) descreve que:

No século $\mathrm{XV}$, quando os navegadores europeus descobriram povos fisicamente diferentes deles, isto é, os ameríndios, os africanos, os "primitivos" da Oceania, entre outros, colocou-se a questão de saber se esses recém-descobertos eram bestas ou seres humanos como os europeus. Para que pudessem ser integrados na categoria humana, era preciso comprovar que eram, antes de mais nada, também descendentes de Adão como os europeus. Em outros termos, que eles tinham o mesmo ancestral comum masculino que os europeus, de acordo com o mito bíblico da criação. Lembremo-nos que entre os séculos XV e XVII, o monopólio do conhecimento e da explicação da origem estava nas mãos da Igreja, através da Teologia. (Munanga, 2013,p.176).

Ainda por Munanga(2013) percebe-se que com a queda da influência da Igreja nos poderes, saindo o mundo de uma visão mais teocêntrica para a visão antropocêntrica, justifica-se a suposta inferioridade dos povos não europeus.

Se os conceitos da Igreja são justificativas importantes para a escravização de negros e ameríndios, as concepções científicas feitas a partir do século XVIII têm participação significativa para a formação da nova ordem societária capitalista. Florestan Fernandes(2017), Stuart Hall(2003), Carlos Hasenbalg(2005) são alguns dos autores que apresentam a discussão dos marcadores sociais, associando a questão de desigualdade de classes e desigualdade racial. É na perspectiva de uma sociedade de classes que o termo raça ganha o significado aqui apresentado, sendo utilizado para apontar as diferenças nas relações sociais estabelecidas. Giddens(2001) explica que: 
No âmbito de um sistema racializado, aspectos do dia-a-dia dos indivíduos incluindo o emprego, as relações pessoais, o alojamento, os cuidados da saúde, a educação e a representação legal - são moldados e constrangidos pelas suas próprias posições racializadas dentro do sistema. (Giddens p. 264).

Com o fim da escravidão e a abertura de uma nova ordem econômica, torna-se necessário definir o lugar social da massa até então escravizada e as teorias racialistas do século XVIII contribuem, em grande parte, para a definição da colocação dos negros na sociedade brasileira, a partir dos anseios da elite, no fim do século XIX. O então, Imperador do Brasil recebe visitas do Conde Arthur de Gobineau, um filósofo, escritor e diplomata francês e este diz que o grande problema do país, do qual não vislumbra nenhuma possibilidade promissora, é a mestiçagem; considera o povo brasileiro feio e suas posições e teorias são influenciadoras de vários outros intelectuais da época. Este período é marcado por debates intensos sobre a influência das raças no futuro da nação. Vários autores estudiosos da questão racial trazem o acontecimento, o que destacamos são os registros trazidos por Oliveira e Sacramento (2013), em artigo do Curso de Educação e Relações Raciais.

Com o fim da escravidão no ano de 1888, uma das alternativas para a não existência de pessoas negras no país é a substituição, através dos incentivos de imigrantes europeus de outros países, como Itália e França. É previsto também um branqueamento da nação. Oliveira e Sacramento(2013) relatam que o antropólogo João Batista de Lacerda no Io Congresso Internacional sobre Raças Humanas, que aconteceu em Londres em julho de 1911, "apresentou tese sobre a mestiçagem brasileira, como problema que seria resolvido pelo branqueamento do povo através da mestiçagem seletiva e da imigração europeia" (Oliveira e Sacramento, 2013, p. 209).

Esta miscigenação que enseja ao embranquecimento da população brasileira, obviamente, não acontece, porém os mecanismos para os estabelecimentos dos papéis determinantes a cada raça permanecem na constituição intelectual. Em 1933 é lançado o clássico Casa Grande e Senzala, do antropólogo Gilberto Freyre, no livro o autor faz um estudo antropológico, onde as relações estabelecidas na construção do povo brasileiro entre ameríndios, portugueses e negros é o elemento. Este é o inicio do processo de compreensão de um país estabelecido dentro de uma democracia racial, que só começa a ser desconstruída a partir da década de 1970, com estudos de Thomas Skidmore, historiador norteamericano, brasilianista: Preto no Branco: raça e nacionalidade no pensamento brasileiro, de 1976.

Os índices de desigualdades entre negros e brancos, apontados nos principais órgãos de estudos demográficos do Brasil demonstram que é preciso desconstruir os ideais de democracia racial no Brasil, sendo este um importante passo para a diminuição das desigualdades sociais presentes na sociedade brasileira.

A educação também se torna, junto as teorias racialistas e outros meios, um importante mecanismo na formação do aparelho ideológico que se constituiu nesses anos para a formação da sociedade brasileira e suas diferenças sociais envolvendo raça e cor.

Até o ano de 1988, a educação brasileira trazia unicamente em seu currículo o olhar a partir do eurocentrismo. Fruto de movimentos sociais, em especial o movimento negro, no ano de 2003 é aprovada a lei que obriga o ensino da história e cultura afro-brasileira, nas escolas brasileiras. Mais adiante, no ano de 2008, é aprovado, através da lei 11.645/2008 a obrigação da inserção do ensino da história e cultura dos povos originários da terra no Brasil, complementando a lei de 2003.

A pedagogia possui várias vertentes teóricas, mas para a compreensão de como funciona sua intervenção no assunto aqui abordado o foco desse trabalho privilegiará apenas três, compreendendo que sua ação é determinante na formação da sociedade.

Oliveira e Sacramento (2013) destacam quanto à teoria tradicional:

[...] aspectos gerais: comprometimento com a permanência do status quo, desvinculação completa da relação entre a educação e a vida dos estudantes, valorização do ensino humanístico e da cultura geral, ênfase nas "obras-primas da leitura e da arte, raciocínios e demonstrações plenamente elaborados, aquisições científicas adquiridas pelos métodos mais seguros" (Oliveira e Sacramento Apud Snyders, 2013, p. 252). 
Na pedagogia tradicional há a repressão do pensamento crítico, neste sentido é inconcebível a ideia de uma sociedade diferente da posta. Cabe ressaltar que no Brasil ainda é a pedagogia tradicional, segundo Libâneo (2012): "Não é exagero afirmar que na maior parte das escolas brasileiras, em quase todos os níveis e modalidades de ensino, predomina a pedagogia tradicional.”(Libâneo, 2012, p. 18).

Outra vertente importante a ser abordada é a escolanovista ou a Escola Nova que em sua metodologia compreende o aluno como centro de sua atuação, priorizando suas necessidades, porém com práticas tecnicistas.

A teoria pedagógica que mais representa a proposta da implementação das leis 10639/03 e 11.645/08 é a progressista. Sua função integrada à vida do estudante, com participação ativa e promoção da consciência crítica traz importante instrumentalização para métodos de impacto na vida da sociedade.

\section{RESULTADOS E DISCUSSÃO}

Entre os professores pesquisados, 38\% se identificam com o gênero masculino e $62 \%$ com o gênero feminino. Segundo Maria Pinto de Carvalho(1999) os dados do MEC indicam que professoras são 85\% do total de regentes da educação básica, "assim, a educação é um campo de trabalho feminino, parte importante do mercado de trabalho das mulheres"(Carvalho, 1999, p. 12).

Quanto ao quesito cor temos então $12 \%$ dos entrevistados que se reconhecem como pretos, $13 \%$ como pardos e $75 \%$ como brancos, nenhum dos entrevistados se identificou como indígena ou amarelo. Esta questão reflete amplamente no fazer profissional, porém, como esse trabalho não possibilita a discussão ampla dos conceitos de raça e etnia, por sua natureza, apenas acrescento que a constituição de um Estado, isto inclui, sua história e cultura predominante, passa pela percepção que seus membros constroem de si.

Dos que se formaram até 1988, ano da Constituição Federal, o total foi de 12\%, o mesmo percentual para os formados entre 1988 e 1996, intervalo de ano entre a determinação na Constituição Federal e a Lei de Diretrizes e Bases da Educação Nacional. Entre os anos de 1996 e 2003, que data da primeira legislação de regulamentação sobre as questões étnico-raciais tem se o percentual de 63\%, a partir deste ano, apresentam-se $13 \%$ dos entrevistados.

Do tempo que lecionam para o ensino médio, o total de entrevistados apresenta 88\% com menos de 15 anos, tempo da vigência da lei 10.639/03, para 12\% entre 25 e 15 anos, o que demonstra a inserção destes, no período entre obrigatoriedade pela Constituição Federal e a regulamentação da lei. Nenhum dos profissionais entrevistados teve formação antes da constituição de 1988.

$14 \%$ dos entrevistados disseram conhecer a legislação, 43\% afirmaram conhecer em parte e o mesmo percentual relatou não conhecer.

Dos entrevistados o total dos que lecionam em ciências da natureza foi de 41\%, Linguagens e Códigos 28\%, Formação Profissional 17\% e Ciências Humanas 14\%.

Gonzaga, Martins e Raykil(2018) analisam que é bem provável que os professores de ciências exatas encontrem dificuldades em inserção na aplicação da lei, porém, isto se reconfigura ao se pensar o currículo de uma forma mais ampla que apenas o conteúdo, mas na inserção de tudo que caracteriza o fazer pedagógico, incluindo a cultura.

As colocações a seguir fazem parte das perguntas abertas. Essa parte se configurou em duas perguntas: a primeira sobre como inserem a legislação em seu fazer profissional e a segunda sobre sua capacitação, estendendo-se todo o seu percurso acadêmico.

Devido à natureza do trabalho, destacam-se algumas falas relevantes à inserção na prática:

Dos professores que disseram inserir a legislação:

"Quando trabalho sobre a população" de professor de geografia, história e sociologia. Existe uma questão importante, não só estatisticamente falando, mas como a compreensão da sociedade ou esta estatística é capaz de projetar consciência crítica e formular soluções para problemas societários. Santos (2009) afirma que: "A Geografia contribui para a formação humana, constituindo referenciais para inserção do indivíduo no mundo, em seus espaços e socialização." (Santos, 2009, p.15). Mais adiante em seu livro o autor diz que: 
Existem, portanto, geo-grafias do racismo e das relações raciais: o racismo, ao definir clivagens sociais e hierarquizar indivíduos e grupos a partir de seus pertencimentos raciais, se expressará na constituição de "lugares" (nos sentidos especial e social) onde a presença do desfavorecido será majoritariamente (lugares da pobreza, da despossessão, da subalternidade)e lugares onde a presença será minoritária (lugares da riqueza, do poder, do saber socialmente legitimado, etc): lugares com a marcas da distinção social. Segundo a perspectiva de Porto- Gonçalves, esta construção - que tem (espaço) material e o simbólico como indissociáveis - está na própria base da conformação da subjetividade e das identidades dos grupos. (Santos, 2009, p.19).

Outra resposta em destaque é:

"Ao trabalhar com estatísticas, quando há problemas relacionados (em Matemática) sempre surgem problemas e/ou discussões sobre o assunto, gerando debates” - de professor de matemática. Aqui se percebe, conforme as questões já discutidas, que inserem o uso de dados para a compreensão da realidade e realizam a interdisciplinaridade.

Dos professores que não inserem a legislação, encontramos as seguintes questões:

"Dentro da minha formação, não tenho nenhuma lembrança em diversidade étnico-racial. Provavelmente, devido a minha formação original em Engenharia" neste relato percebemos que não há ainda a percepção da interdiciplinaridade na concepção de educação do professor entrevistado, ou do multiculturalismo, tendo em vista que construções estão presentes em todos os continentes habitados.

No entanto, a frase que mais teve simbologia à nossa compreensão diz respeito ao seguinte:

"Faço parte de uma geração que aprendeu um artigo constitucional: somos todos iguais perante a lei. Nesse sentido, não defendo a existência de privilégios para nenhum grupo específico.". A pergunta em questão era: Em relação à diversidade étnico-racial, quais lembranças você tem de sua formação (contando desde o ensino fundamental)?

A análise que imputo aqui tem relação ao não entendimento da lei, porém, é de suma necessidade que se associe a pretensão de projeto societário. Trindade (2007) relata que "Nós descendentes de africanas e africanas, estivemos oficialmente nos currículos escolares, sobretudo no dia 13 de maio, na subalternidade, na estereotipia, na invisibilidade." (Trindade, 2007, p. 8 e 9).0s questionamentos da autora trazem luz à análise que podemos fazer da concepção de todos iguais entendida pelo entrevistado. Neste sentido, demarcando as identidades construídas, questionamos como a História, em sua totalidade, (não só no sentido cronológico, mas no sentido constitutivo de uma nação, dos povos negros e indígenas) faz parte da educação do povo brasileiro

\section{CONSIDERAÇÕES FINAIS}

Para a manutenção dos papéis socialmente atribuídos muitos são os caminhos tomados pela classe dominante, no entanto, a luta realizada pela consciência coletiva aponta para caminhos que se utilizam dos próprios mecanismos de dominação para sua desconstrução. Mészaros (2008) traz este contra ponto, onde coloca que apesar da dominação ideológica do capital,

"a intervenção positiva da educação na elaboração dos meios de contrapor-se com êxito à dominação do capital, pelo estabelecimento das formas organizacionalmente viáveis de solidariedade socialista, é vital para o cumprimento do grande desafio internacional de nosso tempo histórico." (Mészaros, 2008, p. 124)

Então para que a educação realize esta intervenção positiva, alguns elementos devem ser desconstruídos e um deles está na própria percepção do educador, Marx(1845) a este respeito disse:

"A teoria materialista de que os homens são produtos das circunstâncias e da educação e de que, portanto, homens modificados são produto de circunstâncias diferentes e de educação modificada, esquece que as circunstâncias são modificadas precisamente pelos homens e que o próprio educador precisa ser educado."(Marx, 1845, p.1) 
Historicamente o Brasil formou sua base social através das diferenças de "raças" e classes, que têm seus reflexos nos dados sociais apontados por diversos órgãos. A pedagogia implementada na construção da educação no Brasil pode ser um instrumento que ajude a contribuir com o aumento das desigualdades ou pode se pautar no combate a estas.

Segundo Costa (2012) "O estudo das teorias educacionais e de currículos nos possibilita compreender as contradições da vida em sociedade, assim como novas bases epistemológicas possibilitam forjar concepções de currículo, educação e sociedade." (Costa, 2012, p. 293). Tendo a educação como um dos aparelhos ideológicos do Estado e compreendendo que Estado está baseado na lógica capitalista, percebemos que as reproduções no âmbito da formação de professores, apesar dos avanços alcançados pela lutas de movimentos sociais em defesa da equidade racial no país, ainda representa um desafio onde o ciclo traçado ainda está em formação.

Até o ano de 1988, a educação oficial, legalizada, contemplava apenas uma etnia, suas culturas e histórias. A partir da Constituição Federal estabelecida no ano em questão, ocorreu a necessidade de se reformular o currículo apresentado na educação nacional: legislações, parâmetros, diretrizes foram constituídas, desde então, no entanto, os impactos ainda são ínfimos para a transformação social. É preciso o reconhecimento da subjetividade dos sujeitos que estão na prática, compreendendo aqui identidades como um conjunto social, político, cultural que se engendram na subjetividade do sujeito e que esta mesmo é flutuante, podendo ser modificada.

0 pedagogo, nas suas diversas possibilidades de atuação no âmbito escolar, deve também mediar a ação do professor com a educação. Com a inserção das leis 10.639/03 e 11. 645/08, amparado também pela Lei de Diretrizes e Bases da Educação (Lei 9394/96) que determina que sejam levadas "em consideração as contribuições das diferentes culturas e etnias para a formação do povo brasileiro, especialmente das matrizes indígena, africana e européia (LDB, art.26aㅜ1996)," ou pelos Parâmetros Curriculares Nacionais, não só uma questão legal se caracteriza neste fazer profissional,mas também se assinala, nesta ação, uma atuação social, que pretende fazer reconhecer no trabalho do pedagogo a possibilidade de uma educação que forme estudantes críticos, capazes de construir uma nova ordem social, permeada de maior equidade e capaz de formar para o respeito a diversidade humana.

\section{REFERÊNCIAS}

[1] Bardin, L. Análise de Discurso. Disponível para download em <https://edisciplinas.usp.br/pluginfile.php/4295794/mod_resource/content/1/Bardln\%2C\%20>. acesso em $23 / 11 / 2018$

[2] Bauman, Z. - Identidade: entrevista a Benedetto Vecchi - tradução Carlos Alberto de Medeiros, Rio de Janeiro, Zahar, 2005.

[3] Brasil - Ministério Da Educação - Lei de Diretrizes e Bases da Educação Brasileira . Lei número 9394/1996 disponível em http://www.planalto.gov.br/ccivil_03/Leis/L9394.htm . acesso em 28 de abril de 2018.

[4] Lei 10639 - Altera a Lei no 9.394, de 20 de dezembro de 1996, que estabelece as diretrizes e bases da educação nacional, para incluir no currículo oficial da Rede de Ensino a obrigatoriedade da temática "História e Cultura Afro-Brasileira", e dá outras providências. Disponível em: http://www.planalto.gov.br/ccivil_03/leis/2003/110.639.htm. acesso em 28 de abril de 2018.

[5] Carvalho, M. P. Um olhar de gênero sobre as políticas educacionais em Gênero e Educação, Cadernos Semprevivas. Nalu Faria, Miriam Nobre, Daniela Auard, Marília Carvalho (orgs), São Paulo: SOF, 1999.

[6] Chiavenato, J. J. 0 negro no Brasil . 1ª Edição . São Paulo, Cortez Editora, 2012

[7] Costa, C. S. Currículos, Relações Étnico-Raciais e os Fundamentos Teóricos da Educação Escolar em Relações Étnico Raciais no Contexto Social, na Educação, 2012. Rio de Janeiro pp 267- 306.

[8] Dantas, C. V. Racialização e Mobilização Negra nas Primeiras Décadas Republicanas em Cadernos PENESB n. 12. Especial Curso ERER , 2ª Edição, pp 135-146, 2013.

[9] Fernandes, F. Significado do Protesto Negro. 1aㅡ. Ed. São Paulo/ Expressão Popular c0-edição Fundação Perseu Abramo.

[10] Freyre, G. Casa Grande \& Senzala, Formação da Família Brasileira sob Regime da Economia Patriarcal: 48 Edição (2003), disponível em PDF em: <http://www.usp.br/cje/anexos/freire_gilberto_casa_grande_senzala.pdf> acesso em 30 de abril> de 2018

[11] Giddens, A. “Classe, estratificação e sociedade”. Sociologia. 6ํeed. Porto Alegre: Artmed, 2008. 
[12] Gonzaga, K 51. . R.; Martins, A. R.; Raykil, C. O professor de química e a lei 11.645/08: discutindo a educação das relações étnico-raciais em Porto Seguro. Revista Eletrônica Científica Ensino Interdisciplinar. Mossoró, v. 4, n. 10, pp. 51-68, 2018. Disponível em <http://periodicos.uern.br/index.php/Recei/article/viewFile/2338/1530> acesso em $03 / 11 / 2018$.

[13] Hall, S. Da diáspora: Identidade e mediações culturais. Trad. Adelaine La Guardiã Resende: Belo Horizonte/Brasília: Editora UFMG/Representação da UNESCO no Brasil, 2003.

[14] Hasenbalg, C. Discriminação e Desigualdades Raciais no Brasil - Traduzido por Patrick Burghin: $2^{2}$ ed . Belo Horizonte: Editora UFGM; Rio de Janeiro: IUPERJ, 2005

[15] Libâneo, J. C. Pedagogia Tradicional Notas Introdutórias . disponível em <http://professor.pucgoias.edu.br/SiteDocente/admin/arquivosUpload/5146/material/Pedagogia\%20Tradicional\% 202012\%202.pdf> acesso em 10/06/2018.

[16] Mészáros, I. A Educação Para Além do Capital: 2ª Ed. São Paulo: Boitempo, 2008.

[17] MARX, K.F. Teses sobre Feuebach. Disponível em

http://www.dominiopublico.gov.br/download/texto/ma000081.pdf acesso em 23/11/2018

[18] Munanga, K. Teoria Social e Relações Raciais no Brasil Contemporâneo em Cadernos Penesb Vol. 12. Especial Curso ERER . Iolanda de Oliveira, Maria das Graças Gonçalves, Tânia Mara Pedroso Muller (organizadoras), pags.163 à 197, 2ª Edição, Editora UFF, 2013.

[19] Oliveira, I. ; Sacramento, M. P. Raça, Currículo e Práxis Pedagógica, Relações Raciais e Educação: O Diálogo Teoria/Prática na Formação de Profissionais do Magistério em Cadernos PENESB Vol. 12, Especial Curso ERER, Iolanda de Oliveira, Maria das Graças Gonçalves, Tânia Mara Pedroso Muller (organizadoras)-pags. 199 à 280 - 2ª Ed. Editora UFF, 2013.

[20] Santos, R. E. Discutindo o Ensino de Geografia: Temas da Lei 10639 Cadernos CEAP: 1a Ed., Rio de Janeiro: Ceap, 2009.

[21] Skidmore, T. Preto no Branco, Raça e Nacionalidade no Pensamento Brasileiro, São Paulo: Cia das Letras, 1989.

[22] Trindade, A. L. O Projeto Político Pedagógico da/na Escola: Capilarizando a Temática das Africanidades Brasileiras. Rio de Janeiro: CEAP, 2007 


\section{Capítulo 17}

Plano Nacional de Educação: Uma análise sobre as metas para os programas de formação inicial $e$ continuada para professores em exercício da Educação Básica

Ana Maria Freitas Dias Lima

Josseane Araújo da Silva Santos

Lilian Gama da Silva Póvoa

Maria José de Pinho

Resumo: Este artigo apresenta a descrição das metas 15 e 16 do Plano Nacional de Educação concernentes à política de formação de professores da Educação Básica em exercício da rede pública de ensino, por meio de análise da legislação vigente publicada no Observatório do Plano Nacional de Educação. 0 estudo traz considerações acerca da concepção sobre formação de professores ao longo das últimas décadas e correlaciona com a importância da formação desses profissionais para a melhoria da qualidade da educação no país, bem como relata as etapas de elaboração e implementação do Plano Nacional de Educação e a sua atual estrutura. Neste sentido, buscamos apresentar dados referentes às metas sobre formação inicial e continuada e refletir sobre os objetivos e desafios a serem enfrentados para o seu efetivo cumprimento. Foi possível observar com o estudo que as ações sinalizam avanços significativos nos últimos anos para a formação docente e demonstram coerência no desenvolvimento das metas e estratégias. Embora o Plano Nacional de Formação de Professores para a Educação Básica, esteja em andamento e com ajuste de estruturas, há problemas quanto à agilidade na efetivação do novo modelo de atualização do Programa.

Palavras-chave: Formação de professores, Educação Básica, Plano Nacional de Educação. 


\section{INTRODUÇÃO}

O cenário educacional atualmente vivencia crises de caráter multidimensional, que estão relacionadas a aspectos de cunho econômico, social, cultural, estrutural, político e democrático, isto porque, nesse âmbito, podemos visualizar algumas problemáticas que se destacam como a questão de recursos mal alocados, de divergências sobre o currículo, déficit na formação de professores, desvalorização profissional. De acordo com Edgar Morin (2015, p. 65), "é necessário introduzir a crise da educação em um contexto crísico mais vasto, que comporte não só a consideração da cultura juvenil e da situação atual da juventude, mas o conjunto de problemas da sociedade e de uma civilização nos quais estão imersos os problemas da educação". Destarte, Chauí (2003, p.7) complementa que "diante de um mundo globalizado e em transformação constante, a educação permanente ${ }^{19}$ ou continuada é uma estratégia pedagógica indispensável, pois somente com ela, é possível a adaptação às mudanças incessantes".

Diante desse conjunto diverso de fatores do qual faz parte o contexto educacional no Brasil, entendemos que fortalecer a educação superior não é simplesmente torná-la acessível, a formação docente deve ser valorizada, para tanto é preciso formar professores que conheçam os problemas da sociedade e do mundo contemporâneo. De fato, não é uma tarefa simples, em virtude das crescentes mudanças no mundo, seja na revolução digital, como nos comportamentos sociais, portanto, urge necessária. À luz dessa realidade, Cunha (1998, p. 141), corrobora que "a formação inicial tem que fazer jus ao nome" [...] "longe está de esgotar o processo de formação, entretanto é preciso dar base estrutural que favoreça ao professor recursos para o seu desenvolvimento profissional".

Como já mencionado, o processo de formação não se esgota. Nesse sentido, Pimenta (1999, p. 9), ressalta que "pensar a formação do professor é pensar em um projeto único englobando a inicial e a contínua". Para a autora, "a valorização da docência representa a mediação para a superação do fracasso escolar". Sendo assim, a formação inicial e a continuada se constituem em um combate estratégico contra a baixa qualidade de ensino e das altas taxas de analfabetismo. E é exatamente por essa imensa responsabilidade imposta compulsoriamente à profissão do professor, que entendemos que a qualidade da formação oferecida a este profissional resulta diretamente na qualidade da educação básica, ou seja, intrinsecamente, um fator está vinculado ao outro.

Nos últimos anos, estamos acompanhando a elaboração de documentos legais mais consistentes sobre a temática, e dentro desse conjunto de tensão educacional, o presente artigo desenvolverá uma descrição das metas do Plano Nacional de Educação - $\mathrm{PNE}^{20}$, destinadas à política de formação inicial e continuada de professores. No caso em questão, daremos foco à formação de professores em exercício na educação básica, por meio de dois programas de formação instituídos pelo Governo Federal - especificamente, o Programa de Formação de Professores para a Educação Básica - Parfor, e a sua proposta de atualização para o Programa de Formação Inicial e Continuada, o Profic. 0 objetivo é compreender como estão sendo conduzidas as estratégias de formação inerentes a esses programas, se houve alterações e se há avanços no novo modelo proposto, considerando os objetivos das metas 15 e 16 do Plano Nacional de Educação.

\section{METODOLOGIA}

Para delinear nossa discussão, faz-se uma breve explanação sobre as diversas concepções sobre formação de professores ao longo das últimas décadas, considerando a repercussão dos debates sobre a necessidade de uma legislação adequada, que viesse a garantir uma formação de qualidade aos professores do país. Em seguida, destaca-se a importância da formação no processo de superação do fracasso escolar, e a sua relação com a melhoria da qualidade da educação no Brasil. Logo após, apresenta-se as etapas de elaboração e implementação do Plano Nacional de Educação e a sua atual estrutura e objetivos, seguida da análise das metas que contemplam a formação e inicial e continuada, as estratégias, o percentual das ações atingidas e os desafios a serem enfrentados para o seu efetivo cumprimento. Em seguida, destaca-se o Programa Parfor e sua versão atualizada, o Profic, a formação continuada dentro do contexto do Plano Nacional de Educação, sua estrutura de funcionamento, objetivos e resultados.

\footnotetext{
${ }^{19}$ Segundo Chauí, a educação é inseparável da formação e é por isso que só ela pode ser considerada permanente. 20 O Plano Nacional de Educação (PNE) é uma lei ordinária, prevista na Constituição Federal, que entrou em vigência no dia 26 de junho de 2014 e valerá por 10 anos. Ela estabelece diretrizes, metas e estratégias de concretização no campo da educação. A partir do momento em que o PNE começa a valer, todos os planos estaduais e municipais de Educação devem ser criados ou adaptados em consonância com as diretrizes e metas estabelecidas por ele.
} 
Neste trabalho, buscamos fundamentação em autores com experiência em pesquisas sobre educação e formação de professores, Chauí (2009), Cunha (1998), Pimenta (1999) Morin (2015), Moraes (1996) e Pinho (2007), além de apresentação da legislação concernente ao assunto, a fim de fundamentar a discussão sobre o tema. Trata-se, portanto, de promover uma correlação entre os já referidos programas de formação de professores em exercício e as metas sobre formação inicial e continuada do Plano Nacional de Educação, a fim de analisar os resultados obtidos até o momento.

\section{RESULTADOS E DISCUSSÃO}

Nas últimas décadas, a formação de professores no Brasil vem variando em conformidade com as políticas educacionais e passando por diversas mudanças conceituais, desde a ruptura do movimento tecnicista, que predominava até os anos de 1980. Sobre esse processo, podemos complementar com a colocação de Cunha (1998 p.136), ao afirmar "que as mudanças no conceito de formação são fundamentais para construir alternativas mais eficazes para a formação de professores"

Sob esta ótica, constata-se que ao longo desses anos, o movimento dos educadores promoveu vários debates sobre as concepções de formação de professores, onde se destacou a necessidade de formação de um profissional que permitisse a transformação da educação e da sociedade, através da sua compreensão da realidade e postura crítica.

Na década de 90 a tendência era a lógica do capitalismo neoliberal e da intervenção mínima do Estado na economia do país, inclusive no financiamento de políticas públicas. O Catálogo da Rede Nacional de Formação Continuada de Professores de Educação Básica (2008, p. 12), enfatiza: "nesse cenário, o Governo Federal, seguindo a tendência das reformas liberalizantes que se estendiam para toda a América Latina, buscou adequar as políticas educacionais às exigências da reforma do Estado e redefiniu o sistema educacional para o discurso da pedagogia das competências", fenômeno que é fortemente observado no mundo produtivo, ou seja, voltado para o mercado de trabalho, em que se destacam os atributos individuais do trabalhador.

Todavia, a partir da promulgação da nova Constituição Brasileira de 1988 e com a Lei de Diretrizes e Bases da Educação Nacional, de 1996, ocorreu o surgimento de dispositivos legais, normas e regras que impulsionaram um grande avanço para a legislação educacional. Sobre este panorama, Pinho (2007, p. 31), corrobora que "na verdade, a reforma educacional brasileira remonta à constituição Federal de 1988, quando inicia seu trâmite no Congresso Nacional, o Projeto de Lei no $1.258 / 88$, denominado Jorge Hage, que versava sobre as diretrizes e bases para a educação nacional.

Tal avanço, proporcionado por ambos os documentos citados, se estabeleceu principalmente na elaboração de um plano específico para a educação brasileira, o Plano Nacional da Educação, conhecido como PNE, onde são apresentadas propostas com diretrizes para uma política articulada e que fornece garantias para a promoção de uma formação inicial e continuada, mediante a equalização de oportunidades educacionais e padrão mínimo de qualidade do ensino.

Ao iniciarmos este artigo falávamos da crise educacional e da interligação entre os demais contextos em crise na sociedade atual. É consensual que a formação de professores é considerada como fator indiscutível de melhoria desse conjunto que há muito tempo engendrou, especialmente, no que tange aos baixos índices de qualidade da educação nacional e das taxas altas de analfabetismo. Porém, pensar no aumento da qualidade da educação básica, e não pensar naqualidade do processo de formação do professor, enquanto mediador para a superação do fracasso escolar implica em não articular as totalidades da crise da educação. Assim, conforme Moraes (2018, p. 63):

A visão de totalidade, o pensamento sistêmico aplicado em educação, nos impõe a tarefa de substituir compartimentação por integração, desarticulação por articulação, descontinuidade por continuidade, tanto na parte teórica quanto na práxis da educação. Em termos de macroplanejamento, esse pensamento evita a concepção de uma política fragmentada, desarticulada, descontínua e compartimentada. Pressupõe novos estilos de diagnósticos, procedimentos metodológicos adequados e que permitam apreender o real e suas múltiplas dimensões, em toda a sua complexidade, para que se possam identificar necessidades concretas, capazes de subsidiarem a construção de uma política educacional congruente com a realidade. 
Nota-se que para a autora, é evidente a necessidade da construção de uma política educacional que corresponda à realidade, através de diagnósticos adequados.

Para Chauí (2003, p.11) "a educação é inseparável da formação", e o Estado não deve tomar a educação pelo prisma do gasto público, e sim, como um investimento social e político, o que só é possível se a educação for considerada um direito e não um privilégio, e nem um serviço. Valorizar a formação consiste em estabelecer condições para a sua realização, por meio de políticas públicas educacionais que articulem ações e coordenem sua execução, além de ser considerada uma prioridade. Logo, para falarmos em melhoria na qualidade da educação no País, e formação de professores, trataremos indispensavelmente da criação do Plano Nacional de Educação - PNE.

O primeiro PNE foi criado em 1996 e vigorou entre os anos de 2001 a 2010. 0 plano original não foi exitoso por haver ausência de metas específicas, ou metas inalcançadas. Então, na busca de um plano que pudesse trazer melhores resultados para a educação brasileira, um novo plano foi levado para aprovação na Câmara e posteriormente para o Senado, entre 2012 e 2013, e em 25 de junho de 2014, após quatro anos de tramitação, foi sancionado sem vetos pela Presidente Dilma Rousseff. O novo plano possui 20 metas e visa alcançá-las até 2024.

O observatório do Plano Nacional de Educação ${ }^{21}$ define que o documento é Lei. Mais precisamente a Lei $\mathrm{n}^{\mathrm{o}}$ 13.005, de junho de 2014, e como legislação, o plano atual não está sozinho, há um mecanismo de leis que baseia a sua fundação e orienta a sua existência a cada decênio.

No atual PNE, temos o professor como protagonista, no que diz respeito à formação. A meta 15 estipula a criação de uma política nacional de formação docente, visando a garantia de curso superior específico na área em que lecionam. Entram nesse ponto também melhorias no currículo das graduações, oferta de bolsas de estudo a professores, valorização do estágio e aprimoramento da formação de outros profissionais da educação. Alinhada a essa meta está a meta 16, cuja proposta é oferecer cursos de pósgraduação a 50\% dos docentes da Educação Básica.

Seguindo este fluxo, em 2009, foi criado o Plano Nacional de Formação de Professores da Educação básica (Parfor), com a intenção de formar 330 mil professores que atuam na educação básica e ainda não possuíam graduação. Nesta proposta, a universidade pública tem a responsabilidade de apresentar as condições de formação para esses professores. Estão envolvidas na oferta de cursos, as universidades federais, estaduais e institutos federais, tanto no modelo presencial, quanto à distância. Por meio do Decreto 6755/09, consolida-se, portanto, um programa para a melhoria da formação inicial dos professores da educação básica, ação que faz parte do PDE Plano de Desenvolvimento da Educação.

Após nos situarmos brevemente no contexto das formulações do Plano Nacional de Educação, faz-se necessário esclarecer que o documento apresenta um conjunto de 20 metas e estratégias que contemplam todos os níveis, modalidades e etapas educacionais, bem como os recursos estratégicos para a sua viabilização. Sobre formação de professores em exercício, temos a meta 15 do PNE, que estabelece estratégias para a formação docente:

Garantir, em regime de colaboração entre a União, os Estados, o Distrito Federal e os Municípios, no prazo de 1 (um) ano de vigência deste PNE, política nacional de formação dos profissionais da educação de que tratam os incisos I, II e III do caput do art. 61 da Lei no 9.394, de 20 de dezembro de 1996, assegurado que todos os professores e as professoras da educação básica possuam formação específica de nível superior, obtida em curso de licenciatura na área de conhecimento em que atuam (Brasil, 2014).

Dados da página do Ministério da Educação - http://portal.mec.gov.br/plano-nacional-de-formacao-deprofessores.

O objetivo estabelecido pela meta 15 foi o de criar uma Política Nacional de Formação de Professores para a Educação Básica até 2015, porém, tal objetivo somente foi cumprido em 2017, e a proposta é de que até 2024, todos os professores da educação básica possuam educação superior obtida em curso de licenciatura na área de conhecimento em que lecionam.

\footnotetext{
${ }^{21}$ Observatório do PNE é um instrumento de monitoramento do Plano Nacional de Educação (PNE) que tem por objetivo contribuir para que ele se mantenha vivo e cumpra seu papel como agenda norteadora das políticas educacionais no País.
} 
De acordo com os dados do observatório do PNE, em 2017, 47,3\% dos professores dos anos finais do Ensino Fundamental possuíam formação superior na área em que trabalham, já no Ensino Médio esse número era de 55,6\%. Quando observados apenas os docentes com licenciatura, as porcentagens são menores: em 2017, o Brasil contava com 70,7\% desses profissionais com essa formação, em números absolutos cerca de 1,5 milhões de professores.

Conforme informado no PNE, em 2017, 78,3\% dos professores possuíam curso de Educação Superior, em números absolutos, mais de 1,7 milhão. Essa porcentagem apresentou crescimento de 11,3\% desde 2008. Ainda há professores atuando sem a licenciatura, motivo pelo qual houve a necessidade de intervenção para atendimento ao que estabelece o artigo 62 da Ldben:

Art. 62. A formação de docentes para atuar na educação básica far-se-á em nível superior, em curso de licenciatura, de graduação plena, em universidades e institutos superiores de educação, admitida, como formação mínima para o exercício do magistério na educação infantil e nos 5 (cinco) primeiros anos do ensino fundamental, a oferecida em nível médio na modalidade normal. [..] $§ 2^{\circ}$ o A formação continuada e a capacitação dos profissionais de magistério poderão utilizar recursos e tecnologias de educação a distância. § 3ํㅗ A formação inicial de profissionais de magistério dará preferência ao ensino presencial, subsidiariamente fazendo uso de recursos e tecnologias de educação a distância (Brasil, 1996).

A meta 15 se desdobra em treze estratégias, contudo, a estratégia 15.1, trata sobre atuar conjuntamente, com base em plano estratégico que apresente diagnóstico das necessidades de formação de profissionais da educação e da capacidade de atendimento, instituições públicas e comunitárias de educação superior existentes nos Estados, Distrito Federal e Municípios, além de definir obrigações recíprocas entre os partícipes - a estratégia foi cumprida, e a matéria é objeto do Plano de Ações Articuladas - PAR e do Programa Nacional de Formação de Professores da Educação Básica - Parfor, programa do qual trataremos especificamente, mais a frente, dentro da perspectiva do PNE.

Já a meta 16 determina que até 2024 sejam formados em nível de pós-graduação, 50\% dos professores da educação básica e estabelece garantia de formação continuada em sua área de atuação aos professores da educação básica:

Formar, em nível de pós-graduação, 50\% (cinquenta por cento) dos professores da educação básica, até o último ano de vigência deste PNE, e garantir a todos (as) os (as) profissionais da educação básica formação continuada em sua área de atuação, considerando as necessidades, demandas e contextualizações dos sistemas de ensino (Brasil, 2014).

Segundo dados do observatório do PNE, até 2017, 36,2\% dos professores da Educação Básica tinham pósgraduação e 35,1\% dos professores da Educação Básica tinham acesso à formação continuada. A maioria dos professores com pós-graduação possui somente especialização. Do total de funções docentes em 2017, eram 34,4\% com especialização, 2,4\% com mestrado e 0,4\% com doutorado - a soma dos percentuais excede o dado de 34,6\%, pois há profissionais que possuem mais de um tipo de pós. Segundo o OPNE, essa estratégia ainda não foi realizada. Ainda baseado na análise do Observatório do PNE, o grande desafio é oferecer uma formação continuada de qualidade e que ao mesmo tempo supra as lacunas da formação inicial e que mantenha o professor em constante aperfeiçoamento no trabalho.

Nas informações do OPNE, fica clara a necessidade de uma qualificação em nível de pós-graduação na região norte. No Tocantins, por exemplo, conseguimos observar através do gráfico gerado pelo sistema do OPNE, abaixo, um número crescente de professores com pós-graduação: 


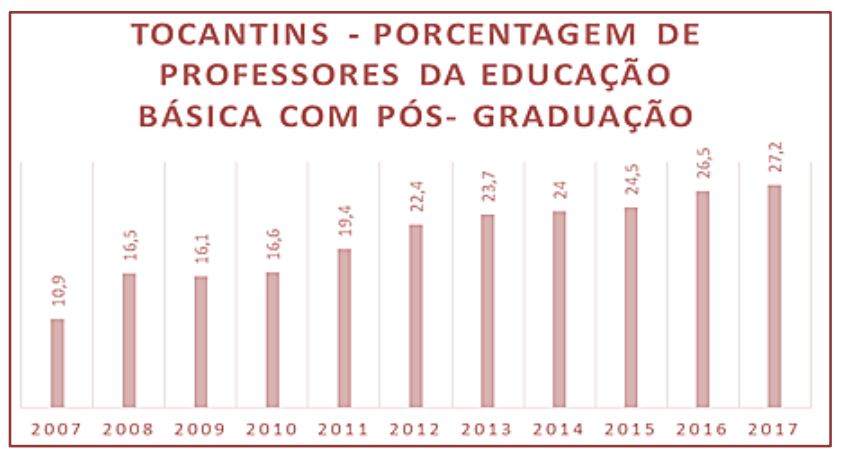

Fonte: Dossiê gerando pelo Observatório do Plano Nacional de Educação (2018).

O Parfor é um programa realizado em regime de colaboração entre a União, os estados, o Distrito Federal e municípios, por intermédio da Coordenação de Aperfeiçoamento de Pessoal de Nível Superior (CAPES) e tem o objetivo induzir e fomentar a oferta de educação superior, gratuita e de qualidade, para profissionais do magistério que estejam no atuando em exercício na rede pública de educação básica.

As instituições de educação superior (IES), em cursos de Primeira Licenciatura, Segunda Licenciatura ou Formação Pedagógica são responsáveis pela implantação das turmas especiais.O programa foi criado em consonância com as metas 15 e 16 do PNE, Lei no 13.005, de 25 de junho de 2014 e com a Lei de Diretrizes e Bases da Educação Nacional, no 9.394 de 20 de dezembro de 1996.

Art. 1o Fica instituído o Plano Nacional de Formação dos Professores da Educação Básica, uma ação conjunta do MEC, por intermédio da Fundação Coordenação de Aperfeiçoamento de Pessoal de Nível Superior - CAPES, em colaboração com as Secretarias de Educação dos Estados, Distrito Federal e Municípios e as Instituições Públicas de Educação Superior (IPES), nos termos do Decreto 6.755, de 29 de janeiro de 2009, que instituiu a Política Nacional de Formação de Profissionais do Magistério da Educação Básica, com a finalidade de atender à demanda por formação inicial e continuada dos professores das redes públicas de educação básica (Brasil, 2009).

De acordo com o com o Manual Operativo do Parfor, disponível no site da CAPES, a formação inicial foi criada para três situações: professores que ainda não têm formação superior (primeira licenciatura); professores já formados, mas que lecionam em área diferente daquela em que se formaram (segunda licenciatura); e bacharéis sem licenciatura, que necessitam de estudos complementares que os habilitem ao exercício do magistério (formação pedagógica). As chamadas instituições formadoras definiriam o processo seletivo, de acordo com a demanda e número de vagas, mas também havia a opção do sorteio eletrônico do MEC. Assim, a partir de 2010 formaram- se as primeiras turmas do Programa Nacional de Formação de Professores para a Educação Básica - Parfor. Em 2017, foi lançada considerando as definições da Lei no 11.273, de 6 de fevereiro de 2006, e as metas 15 e 16, estabelecidas no Plano Nacional de Educação - PNE, o Regulamento do Parfor, através da Portaria 82, de 17 de abril de 2017, e posteriormente, em 15 de agosto do mesmo ano, foi pulicada a Portaria 159, para atualizar a redação dos artigos 34,43 e 45 .

No ano de 2017, a CAPES anunciou um novo programa que iria atualizar o modelo vigente do Parfor. Dentre as mudanças, estaria o método de repasse dos recursos financeiros, que seriam destinados diretamente às instituições. O Programa de Formação Inicial e Continuada para os Professores da Educação Básica (Profic) deveria contar, a princípio, com quatro especializações: Português e Matemática, Educação Infantil e Alfabetização com a previsão para ampliação futura para outras áreas. A plataforma para cadastro e solicitação de vagas no Profic foi aberta em outubro de 2017 para professores da rede pública de todo o país. O Parfor, assim como no modelo existente, funcionará até que seja concluída a última turma, e ambos os programas devem funcionar concomitantemente. A proposta do novo programa inclui ainda a mudança dos currículos dos cursos, cuja experiência dos professores deverá ser contemplada. 
É válido enfatizar que os programas de formação, visam contribuir para o cumprimento das metas 15 e 16 do Plano Nacional de Educação. No Profic, as mudanças se encontram basicamente na estruturação da organização do funcionamento e na oferta de cursos de especialização. No modelo atualizado, a oferta das turmas também ocorrerá em regime de colaboração. De acordo com o disposto Art. 4o da Portaria CAPES no 82/2017, o regime de colaboração consiste na formalização de um Acordo de Cooperação Técnica (ACT), entre o Governo Federal, por meio da CAPES, o Conselho Nacional de Secretários de Educação (Consed) e a União Nacional dos Dirigentes Municipais de Educação (Undime). Em relação às IES, todas devem possuir cadastro na Plataforma Freire 2. A Plataforma Freire 2 (herda o nome do antigo sistema utilizado pelo Parfor) é um site de agregação de currículos de professores da educação básica, gerenciado pela CAPES. Além de funcionar como banco de currículos semelhante ao Currículo Lattes, será um sistema de gestão de cursos de capacitação para os professores. Tal ação é prevista na estratégia 15.4, da meta 15, referente a consolidação e ampliação da plataforma eletrônica para organizar a ofertar e as matrículas em cursos de formação inicial e continuada de profissionais da educação, bem como para divulgar e atualizar seus currículos eletrônicos.

No período das inscrições, as instituições também devem estar cadastradas ao e-MEC, isenta de processo de supervisão e apresentar, quando avaliada, Conceito Institucional (CI) ou Índice Geral de Curso (IGC) igual ou superior a 3. Em caso de IES estaduais e municipais que não aderiram ao Sistema Nacional de Avaliação do Ensino Superior (Sinaes), as instituições precisam também apresentar ato autorizativo de funcionamento da IES expedido pelo órgão de regulação da educação superior de sua Unidade Federativa. 0 Profic ainda não é um programa consolidado. A expectativa é que com a análise da demanda verificada após o cadastro dos professores de todo o Brasil, o programa possa ter andamento.

\section{CONSIDERAÇÕES FINAIS}

O Plano Nacional de Educação definiu em sua meta 15, a elaboração de uma política nacional de formação de professores da Educação Básica, que garante a formação específica em nível superior, por meio de curso de licenciatura na área de atuação. Assim, podemos afirmar que houve um avanço na legislação educacional, quanto à criação de uma política mais adequada, com normas e leis mais consistentes para a formação desses profissionais, principalmente, ao se tratar de propostas que contemplem as experiências dos profissionais em atividade. Dentro desse panorama, o grande desafio será a articulação entre as redes de ensino e as universidades que formarão estes professores, pois, sabe-se que a maioria dos currículos das licenciaturas atuais são elaboradas por especialistas que desconhecem o cotidiano escolar, o que provoca uma grande distância entre a realidade da escola pública e as práticas de ensino. Não obstante, a reforma curricular, é uma estratégia do PNE, ainda em desenvolvimento, e que exige a articulação entre outras políticas educacionais.

Por outro lado, ampliar o quantitativo de docentes que atuam na Educação Básica com graduação e pósgraduação requer, necessariamente, ações conjugadas, posto que a criação de programas de formação por si só, não garante a qualificação dos profissionais. A melhoria da formação docente através da melhoria do equilíbrio entre a teoria e a prática, são questões que permeiam o Plano Nacional de Educação, através também de outros projetos, como o Residência Pedagógica, por exemplo.

Espera-se que o Parfor/Profic, colabore de forma efetiva com cumprimento da meta 16 do PNE, que tem como objetivo principal, ter metade dos professores da Educação Básica pós-graduados até 2024. Em relação às metas direcionadas à formação de professores da Educação Básica, podemos delinear as principais dificuldades, com base na análise do OPNE: é necessário que a Educação Básica entre na agenda de prioridade das universidades: os currículos das licenciaturas pouco tratam das práticas de ensino e são distantes da realidade da escola pública.

Para o cumprimento da meta 16, o maior desafio, é oferecer uma formação continuada de qualidade e que supra as demandas e desafios enfrentados por cada professor, mas para isso é importante que o MEC cumpra seu papel de acompanhamento. No caso dos programas Parfor/Profic, a necessidade está tanto na qualidade como no aumento da oferta de cursos de especialização. 


\section{REFERÊNCIAS}

[1] Brasil. Ministério de Educação e Cultura. LDB - Lei no 9394/96, de 20 de dezembro de 1996. Estabelece as diretrizes e bases da Educação Nacional. Brasília: MEC, 1996.

[2] Lei no N 13.005, de 25 de junho de 2014. Aprova o Plano Nacional da Educação-PNE 2014-2024 e dá outras providências. Presidência da República. Casa Civil. Brasília: DF, 2014.

[3] Disponível em: <http://pne.mec.gov.br/18-planos-subnacionais-de-educacao/543-plano-nacional- deeducacao-lei-n-13-005-2014>. Acesso em: 4 jan. 2019.

[4] Lei no N 13.005, de 25 de junho de 2014. Aprova o Plano Nacional da Educação - PNE 2014-2024 e dá outras providências. Presidência da República. Casa Civil. Brasília: DF, 2014.

[5] Disponível em: <http://pne.mec.gov.br/18-planos-subnacionais-de-educacao/543-plano-nacional- deeducacao-lei-n-13-005-2014>. Acesso em: 4 jan. 2019.

[6] Decreto № 6.755, de 29 de janeiro de 2009. Institui a Política Nacional de Formação de Profissionais do Magistério da Educação Básica, disciplina a atuação da Coordenação de Aperfeiçoamento de Pessoal de Nível Superior - CAPES no fomento a programas de formação inicial e continuada, e dá outras providências. Diário Oficial da União. Poder Executivo. Brasília: DF, 2009.

[7] Observatório Nacional do Plano Nacional da Educação. Brasília: DF, 2013. Disponível em: <http://www.observatoriodopne.org.br/>. Acesso em: 3 jan. 2019.

[8] Rede Nacional de Formação Continuada de Professores de Educação Básica. Brasília: DF, 2006. Disponível em: <http://pne.mec.gov.br/18-planos-subnacionais-de-educacao/543-plano- nacional-de-educacao-lei-n-13-0052014>. Acesso em: 20 dez. 2018.

[9] CAPES. Portaria no 82, de 17 de abril de 2017. Aprova o Regulamento do programa Nacional de Formação de Professores da Educação Básica - Parfor. Diário Oficial da União, Brasília, DF, 20 abr. 2017. p. 23.

[10] Chauí, Marilena de Souza. A universidade pública sob nova perspectiva. Rev. Bras. Educ. 2003, n. 24, p. 5-15.

[11] Cunha, Maria Isabel da. O professor universitário na transição de paradigmas. Araraquara: JM Editora, 1998.

[12] Morin, Edgar. Uma crise multidimensional. In: MORIN, Edgar. Ensinar a Viver - Um manifesto para mudar a educação. Sulina: Editora Meridional, 2015.

[13] Moraes, Maria Cândida. O paradigma educacional emergente. Campinas: Papirus, 2018.

[14] Pimenta, Selma Garrido. Formação de professores: Identidade e saberes da docência. In: Pimenta, Selma Garrido. (Org.) Saberes Pedagógicos e atividades docentes. São Paulo: Cortez Editora, 1999.

Pinho, Maria José. Políticas de formação de professores: Intenção e realidade. Goiânia: Editora Cânone, 200 


\section{Capítulo 18}

\section{O programa formar e suas implicações na Educação Básica Brasileira}

\section{Cristina Maria Bezerra de Oliveira \\ Scheiler Fagundes Carvalho \\ Wellyngton Chaves Monteiro da Silva}

Resumo: Neste texto, nosso objetivo é analisar a participação da Fundação Lemann - por meio do Programa Formar - frente às políticas de formação continuada de gestores e professores da educação básica brasileira, provocando uma correlação de forças na definição do conteúdo e direção da proposta que interferem diretamente nas práticas pedagógicas e de gestão, no 'chão da escola'. Metodologicamente nosso trabalho explorou a pesquisa documental, por meio de convênio e conteúdo do curso Gestão para Aprendizagem, bem como, informações disponibilizadas no site da Fundação Lemann e análise de dados de outros sites, de seus parceiros. Os autores citados no trabalho estão vinculados a uma linha materialista histórica. Selecionamos alguns elementos apresentados pela Fundação Lemann como frentes de trabalho, na atuação de programas e projetos para as redes de ensino, municipais e estaduais, em todas as regiões do Brasil. A escolha por esta Fundação se deu por ser uma das mais novas instituições do terceiro setor e a sua abrangência dentro e fora do país, influenciando políticas de educação pública.

Palavras-chave: Formação continuada. Público-privado. Democratização da educação.

22 Publicado originalmente nos Anais da IV Jorneduc, com outro título: OLIVEIRA, Cristina Maria Bezerra de; CARVALHO, Scheiler Fagundes; SILVA, Wellyngton Chaves Monteiro da. O Programa Formar na direção da educação básica brasileira: avanços ou retrocessos? In: JORNADA IBERO-AMERICANA DE PESQUISAS EM POLÍTICAS EDUCACIONAIS E EXPERIÊNCIAS INTERDISCIPLINARES NA EDUCAÇÃO, 4, 2019, Salvador (BA). Anais..., Salvador: IFBA, v. 4., no. 1, 2019. p.487-498. Disponível em <www.even3.com.br/anais/ivjorneduc>. (ISSN: 2525-9571). 


\section{INTRODUÇÃO}

O Estado continua sendo o responsável pelo acesso à educação, inclusive ampliando as vagas públicas, mas o conteúdo pedagógico e de gestão da escola é cada vez mais determinado por instituições que introduzem a lógica mercantil, com a justificativa de que, ao agir assim, estão contribuindo para a qualidade da educação pública. Assim, o objetivo deste trabalho é identificar como o processo de privatização está ocorrendo, tanto através da oferta (quando uma instituição privada assume a execução da política pública), como através da direção (quando a instituição permanece pública, mas uma organização social assume o conteúdo definindo processos de gestão, de currículo e a formação de professores), por meio do Programa Formar, da Fundação Lemann.

Justifica-se este estudo, que tem como tema "o Programa Formar na direção da educação básica brasileira: avanços ou retrocessos?" em face de um contexto de correlação de forças que coloca a educação brasileira sob a mira de "grupos de intelectuais da classe empresarial com composição diversa, mas, que atuam em comum como porta vozes desta classe" (RUIZ, 2017, p.16), com isso, somamo-nos a outras pesquisas que assumem a Fundação Lemann como tema de debate.

Para este estudo, lançamos mão da pesquisa documental, buscando analisar os documentos divulgados no site da Fundação Lemann, tais como relatórios anuais de suas frentes de trabalho, boletins informativos, bem como, documentos oficiais no âmbito estadual e federal que tratam dos convênios e/ou parcerias público-privadas. Para identificar como as ações estão sendo praticadas pelos participantes do curso de formação, realizamos entrevistas semiestruturadas com gestores e professores do Sistema Estadual de Educação Básica Pública de Alagoas, onde a pesquisa está sendo realizada, por amostragem, aos participantes do curso Gestão para Aprendizagem. Tais instrumentos demonstram uma intencionalidade que precisa ser desvelada e compreendida pelo conjunto de educadores que ora se vêm dentro de um contexto em que, muitas vezes, não foram consultados sobre sua participação.

Na organização do texto, inicialmente, debatemos uma série de discussões acerca das questões ligadas às parcerias púbico-privadas a partir de autores e pesquisas que, da mesma forma, vêm se dedicando a este tema e, sobretudo, seus impactos na educação e na gestão da educação pública brasileira. Em seguida, apresentamos com mais detalhamento o próprio Programa Formar; o conteúdo da proposta do seu curso de formação - Gestão para Aprendizagem. Finalizaremos com nossas considerações acerca do conteúdo da proposta do curso e de suas práticas, in loco.

\section{ASPECTOS TEÓRICO-METODOLÓGICOS DA PESQUISA}

A perspectiva teórico-metodológica que fundamenta nossa pesquisa é de cunho materialista-dialético, onde buscamos compreender a reforma do aparelho de Estado que afeta sobremaneira as mudanças de paradigmas na educação, como parte das mudanças sociais e econômicas, bem como, a materialização da relação público-privada no sistema educacional brasileiro, e, bem especificamente, em Alagoas, onde teremos como foco as implicações estabelecidas entre as redefinições do papel do Estado e a correlação de forças que perpassam a educação básica pública, junto às parcerias com o setor privado, nesse caso, com a Fundação Lemann.

Entendemos que a relação entre o público e o privado na política educacional é parte constitutiva das mudanças sociais e econômicas que passa, principalmente, por uma relação em processo (THOMPSON, 1981), e, mais precisamente sobre como as parcerias público-privadas têm mostrado os interesses dos grupos economicamente hegemônicos, sobremaneira, os apontados nos estudos de referências desenvolvidos por Peroni e Adrião $(2005,2006,2007,2011,2013,2015)$, que também trazem categorias comuns aos nossos estudos.

Nossa atenção aqui, se volta para uma situação específica, sem perder de vista todo o contexto nacional que coloca o privado na direção das políticas de educação no Brasil, o que nos leva a refletir junto com Kosik (1976, p. 218) que "fazer as costuras teóricas e realizar a desconstrução do mundo da pseudoconcreticidade exige o estabelecimento de mediações [...] para identificarmos as estratégias e sua atuação na esfera pública na área da educação, apontando possíveis desdobramentos para a escola". E neste caso, referimo-nos à Fundação Lemann e suas estratégias e atuação na esfera pública educacional e seus desdobramentos.

No período atual e particular do capitalismo, as políticas sociais passam a ser assumidas pela sociedade civil, servindo de mercadorias ofertadas às instituições privadas. Conforme argumenta Sanfelice (2006, p.62), "ONGS, trabalho voluntário, parcerias e outras práticas estão na moda. É voluntarismo, 
assistencialismo focados na mercantilização dos direitos sociais". Conforme explicam Deitos e Xavier (2006, p. 69), "uma sociedade capitalista, e seu Estado político de afirmação permanente, jamais poderia universalizar as políticas sociais, se as entendermos como expressão de contradições inerentes à ordem social estabelecida". Assim, para que a sociedade passe a acreditar no cumprimento do seu papel, de universalizar as políticas sociais, o Estado condiciona a materialização das políticas educacionais à celebração de parcerias com o setor privado.

\subsection{CONCEITOS NORTEADORES E CATEGORIAS DE ANÁLISE}

O conteúdo da proposta do Programa Formar nos acompanhará neste trabalho, bem como sua especificidade para uma de suas frentes, a formação continuada para gestores e professores por meio do Curso Gestão para Aprendizagem. Para que possamos instrumentalizar nossas análises, conceitos como Democracia, em Wood, "democracia como direitos sociais materializados em políticas" (2003), "a não separação entre o econômico e o político" (2014), e de Estado, na concepção de Vieira, "coletivização das decisões" (1988), também servirão como forma de pensar o nosso próprio contexto de pesquisa.

Para Vieira (1988, p.12), “a democracia não pode ser compreendida como um estágio, mas como um processo", no que concordamos, e nos parece bem atual quando enfatiza que "quanto mais coletivas as decisões, mais democráticas elas serão", e que em "qualquer conceito sobre democracia, importa o grau crescente de coletivização das decisões, visto que a política social é sempre resultado dos reclames sociais" (VIEIRA, 1988, p.12). Evidentemente, toda política precisa ser pensada e implementada a partir dos reclames sociais, da força que emerge dos movimentos dos trabalhadores, das organizações de classe que hoje estão sendo ignoradas pela criminalização da política e pelo estímulo ao descrédito às instituições classistas, que, na verdade, fortalece apenas àqueles que já detêm o poder e que precisam do Estado para "legalizar suas ações".

Contudo, já que a política social não acontece por acaso, Peroni $(2015$, p.17) afirma que "a democracia não é uma abstração, é entendida como a materialização de direitos em políticas coletivamente construídas na autocrítica da prática social”, o que corrobora com Mészáros (2002, p.1008), quando afirma que "[...] programas e instrumentos de ação sociopolíticos verdadeiramente adequados só podem ser elaborados pela própria prática social crítica e autocrítica no curso de seu desenvolvimento".

Isto posto, remetemo-nos à nossa realidade e apatia social, que, muitas vezes, impede as correlações de forças sociais, favorecendo um grau de determinismo da força do capitalismo sobre a sociedade, sem resistência e sem oposição suficiente para fazer frente ao que a hegemonia do capital impõe. Assim é que corroboramos com Bernardi (2016) que a cidadania democrática muitas vezes se apresenta abstrata e passiva, com uma "liberdade de expressão, de imprensa, de reunião, tolerância, proteção de uma esfera privada, na defesa do indivíduo e da sociedade civil contra o Estado" (WOOD, 2003, p. 199), e ainda, que a

[...] cidadania está cada vez mais restrita a processos eleitorais, [...] o capitalismo é incompatível com a democracia, porque restringe o poder popular ao campo político e a escolha formal dos representantes, impedindo que este poder se sobreponha aos imperativos do lucro e da acumulação, sendo inaceitável a participação dos rendimentos (BERNARDI, 2016, p.29).

É mister que não podemos falar de democracia sem também trazer o conceito de Estado, a fim de que possamos entender seu papel na sociedade capitalista e o lugar que as políticas sociais se encontram, nesse contexto em que não é o Estado que determina as relações econômicas, mas é determinado por elas. Para Engels (2008, p. 135-136)

O Estado é: [...] um produto da sociedade, quando esta chega a um determinado grau de desenvolvimento; é a confissão de que essa sociedade se enredou numa irremediável contradição com ela própria e está dividida por antagonismos irreconciliáveis que não consegue conjurar. Mas para que esses antagonismos, essas classes com interesses econômicos colidentes não se devorem e não consumam a sociedade numa luta estéril, faz-se necessário um poder colocado aparentemente por cima da sociedade, chamado a amortecer o choque e a mantê-lo dentro dos limites da "ordem". Este poder, nascido da sociedade, mas posto acima dela, se distanciando cada vez mais, é o Estado.

Com essa exposição de Engels, podemos refletir que o Estado, de fato, é um produto da sociedade em desenvolvimento e em contradições consigo próprio, que precisa do Estado como força conciliadora dos 
antagonismos, mantendo o limite da "ordem". Lênin (1980, p.178), de certa forma, complementa as palavras de Engels ao dizer que toda "[...] teoria do Estado serve para justificar os privilégios sociais, para justificar a existência da exploração, para justificar a existência do capitalismo [...]".

No contexto forjado a partir da aparência de filantropia, as empresas aparecem comprometidas com as questões sociais, com ênfase na educação, lançando mão de estratégias como o terceiro setor para explorar a mercantilização, ou seja, suas ações são pensadas de modo que tenham o retorno através da direção e execução das políticas públicas. Segundo Ball e Olmedo (2013, p. 34), “[...] esses novos filantropos não renunciam totalmente à possibilidade de lucro". Os autores destacam, ainda, sobre "[...] a relação direta entre caridade e política, o envolvimento mais aparente dos doadores com comunidades políticas e uma abordagem mais 'prática' ao uso das doações" (BALL; OLMEDO, 2013, p. 39).

Compreendemos que o Estado faz opção de contratar o privado para trazer a lógica deste para dentro da escola, ou seja, o privado vende uma política educacional pavimentada com valores do mercado e os mesmos determinam a direção das políticas públicas. Ao mesmo tempo que as parcerias aumentam, são reduzidas as políticas sociais, principalmente aquelas reconhecidas como direito universal, como é o caso da educação. Wood (2013) destaca que "o conceito de democracia em uma sociedade sob a hegemonia do capitalismo não pode ser visto em abstrato", pois afinal "É o capitalismo que torna possível uma forma de democracia em que a igualdade formal de direitos políticos tem efeito mínimo sobre as desigualdades ou sobre as relações de dominação e de exploração em outras esferas" (WOOD, 2013, p. 193).

\section{SOBRE O PROGRAMA FORMAR E O CURSO GESTÃO PARA APRENDIZAGEM}

Com início de suas atividades em 2002, pelo empresário Jorge Paulo Lemann, a Fundação Lemann é uma organização familiar sem fins lucrativos, que tem como missão "colaborar com pessoas e instituições em iniciativas de grande impacto que ajudem a garantir a aprendizagem de todos os alunos e formar líderes que resolvam os problemas sociais do país, levando o Brasil a um salto de desenvolvimento com equidade" (LEMANN, 2018).

Para o alcance de seus objetivos, o Programa Formar atua em três frentes: Políticas Educacionais, instituídas a partir de um diagnóstico; Conectividade e Inovação, onde, por meio de uma rede conectada, se mantêm o controle das ações, além de facilitar a comunicação e interação entre professores e gestores; e ainda a Formação Continuada em Serviço, cujo foco é formar/qualificar gestores(as) e professores(as). A ideia é fortalecer e aprimorar as práticas dos educadores a fim de promover melhores aulas e mais qualidade na aprendizagem dos alunos. 0 conteúdo, a forma e o método como são elaborados e executadas estas ações, se inscrevem numa perspectiva gerencialista e meritocrática da educação, por eles pretendidas.

Com duração de até dois anos, o Programa atua de forma integrada em quatro níveis da rede educacional, buscando apoiar desde lideranças pedagógicas da secretaria, até professores que estão diariamente na sala de aula, conforme se pode verificar na Figura 1.

Figura 1 - Sujeitos da rede envolvidos no Programa Formar.

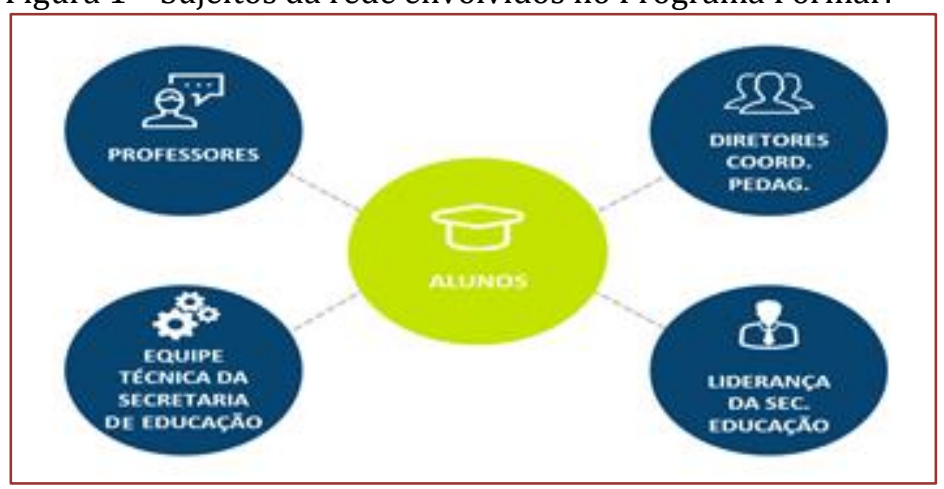

Fonte: Site da Fundação Lemann (www.fundacaolemann.org.br) 


\subsection{FORMAÇÃO CONTINUADA - GESTÃO PARA APRENDIZAGEM}

O propósito do programa é o de promover uma transformação sistêmica junto às redes estaduais e municipais de ensino, atuando em diferentes frentes de trabalho. Uma delas é a consultoria para as lideranças pedagógicas das secretarias, com o objetivo de apoiá-las na definição e implementação de estratégias com foco na melhoria da aprendizagem. A segunda, é a formação em gestão pedagógica para técnicos de secretarias responsáveis pelo acompanhamento das escolas, diretores e coordenadores pedagógicos, buscando formá-los para o uso de técnicas de gestão estratégica, pedagógica e de sala de aula. E o terceiro pilar, a formação em didáticas específicas, que tem como objetivo preparar formadores das secretarias, para que eles possam repassar aos professores da rede um conhecimento das melhores estratégias de ensino e aprendizagem em disciplinas específicas.

As parcerias se materializam de várias formas, e como adverte Peroni $(2015$, p.18), "não tratamos o público-privado apenas como propriedade, mas como projetos societários em relação, permeados por classes sociais em correlações de força", portanto, é nesse sentido que acreditamos que essa expansão de parcerias, sobremaneira, no Nordeste, está relacionada ao contexto histórico e geográfico em que as demandas sociais são maiores e os indicadores educacionais tendem a serem os mais baixos, destacandose as estratégias para definir a direção das políticas de educação.

O conteúdo da proposta: Os primeiro livros, "Planejamento Estratégico: um instrumento para o setor de escola pública”, de Caudia Zappini Dalcorso (2017), e "Aula Nota 10: 49 técnicas para ser um professor campeão de audiência“, de Doug Lemov (2011), foram entregues e estudados com os participantes (um coordenador e um diretor de cada escola "contemplada”), e, por seu conteúdo já evidencia uma mudança na prática e no conteúdo a serem desenvolvidos na escola, reforçando o modelo gerencial e mecânico que ora vivenciamos com o excesso de burocracia e competitividade dentro e fora da escola.

Organizado em módulos, o programa do curso se estruturou conforme o Quadro 1:

Quadro 1 - Estrutura do Curso Gestão para Aprendizagem.

\begin{tabular}{|l|l|}
\multicolumn{1}{|c|}{ Módulo } & \multicolumn{1}{c|}{ Unidades } \\
Introdução à Gestão & $\begin{array}{l}\text { Conceitos de Administração e Gestão Escolar; Gestão com foco na aprendizagem; 0 } \\
\text { papel do gestor para a melhoria da qualidade. }\end{array}$ \\
\hline $\begin{array}{l}\text { Semana 2 - } \\
\text { Gestão Estratégica }\end{array}$ & $\begin{array}{l}\text { Nova concepção de gestão escolar focada na aprendizagem dos alunos e nas dimensões } \\
\text { de trabalho do gestor visando o sucesso escolar, com foco na rede pública. }\end{array}$ \\
\hline $\begin{array}{l}\text { Semana 3 - } \\
\text { Planejamento Estratégico }\end{array}$ & $\begin{array}{l}\text { Diretrizes do planejamento estratégico e algumas etapas que compõem a sua } \\
\text { elaboração. }\end{array}$ \\
\hline $\begin{array}{l}\text { Semana 4 - } \\
\text { Cenário da Escola }\end{array}$ & $\begin{array}{l}\text { Esta unidade apresenta com detalhes alguns instrumentos que contribuem para mapear } \\
\text { o cenário da escola para elaboração do planejamento estratégico: caracterização da } \\
\text { comunidade escolar, avaliação da eficácia de eficácia escolar e a avaliação estratégica. }\end{array}$ \\
\hline $\begin{array}{l}\text { Semana 5 - } \\
\text { Plano de Ação }\end{array}$ & $\begin{array}{l}\text { Nesta unidade você encontrará o passo a passo para a realização de um plano de ação, a } \\
\text { fim de que a equipe escolar possa desenvolver suas ações orientadas por um } \\
\text { planejamento estratégico. }\end{array}$ \\
\hline $\begin{array}{l}\text { Semana 6 - } \\
\text { Materiais de Apoio }\end{array}$ & $\begin{array}{l}\text { Aqui você encontrará todas as Referências Bibliográficas do curso e informações } \\
\text { complementares que podem auxiliar na construção do seu plano de ação }\end{array}$ \\
\hline
\end{tabular}

Os conteúdos abordam uma nova concepção de gestão escolar focada na aprendizagem dos alunos e nas dimensões de trabalho do gestor, visando o sucesso escolar com foco no IDEB, da rede pública. É com essa visão que ratificamos que, “[...] para além de mera aquisição de apostilas ou cursos pelos governos municipais, trata-se da transferência para a esfera privada da função de elaboração e operacionalização de política pública até então exercida pela esfera pública estatal” (ADRIÃO et al., 2009, p. 802).

\section{4. À GUISA DE CONCLUSÃO}

Ainda em processo de construção, já é possível fazer algumas reflexões acerca das parcerias públicoprivadas que emergem em meio à crise política que se abate sob o país, dando-nos a certeza da necessidade de se ampliar análises de políticas públicas como campo investigativo e urgente em diferentes espaços de formação, possibilitando àqueles que estão no 'chão da escola' acompanhar e compreender os 
movimentos e projetos que potencialmente tendem a diminuir o grau de autonomia da escola e dos docentes por meio de práticas centralizadoras e gerenciais.

Neste estudo, analisamos o conteúdo da proposta do curso Gestão para Aprendizagem, e, diante do material e do conteúdo do curso analisado até o presente momento, ficou evidente a orientação gerencialista, meritocrática e estratégica contida no mesmo, haja vista o ponto alto do curso estar voltado para o "planejamento estratégico" e, antes mesmo de iniciar o curso, ainda se faz um diagnóstico para identificar desafios e oportunidades da SEDUC-AL, promovendo um desencadeamento de ações a serem desenvolvidas pela escola, com o estabelecimento de regras, modelos e diretrizes, de modo que as práticas docentes acabam ficando burocratizadas, ou mesmo mecanizadas pelas cartilhas de orientação.

Ainda com o olhar para a formação de gestores, outra forte característica empresarial está relacionada com a análise de SWOT, um sistema simples para posicionar ou verificar a posição estratégica da "empresa" no ambiente em questão. Ou seja, a escola, nessa perspectiva, é uma empresa e, portanto, precisa ser tratada como tal. Para essas organizações mantidas pelo mercado financeiro da educação, interessam os resultados imediatos, visto que o trabalho a ser praticado tem relação direta com os indicadores das avaliações em larga escala, que enaltece o ego daqueles que estão à frente do cenário político e educacional.

Diante da relevância da formação para os trabalhadores em educação, sejam gestores, professores e funcionários de escola, não a desqualificamos, por óbvio, mas problematizamos o fato da própria formação ofertada neste modelo estar mais próxima de "treinar" do que "formar"; muitas vezes repetindo o que lhes são passado, sem reflexão da prática, como nos tempos de outrora, que ao longo dos anos, conseguimos modificar, ainda que timidamente.

Pelo que podemos perceber no programa do curso, ratificamos nossa análise de que o conteúdo da proposta do programa "Gestão para Aprendizagem" nos remete a um novo modelo de gestão e de fazer educação, que está alinhado à lógica mercantil representada pela atuação do setor privado na educação.

\section{REFERÊNCIAS}

[1] Adrião, T.; Garcia, T.; Borghi, R.; Arelaro, L. Uma modalidade peculiar de privatização da educação pública: a aquisição de "sistemas de ensino" por municípios paulistas. Educ. Soc., Campinas, vol. 30, n. 108, p. 799-818, out. 2009.

[2] Ball, S; Olmedo, A. A nova filantropia, o capitalismo social e as redes globais em educação. In: Peroni, Vera Maria Vidal. Redefinições das fronteiras entre o público e o privado: implicações para a democratização da educação. Brasília: Liber Livro, 2013.

[3] Bernardi, L. M. Implicações do Plano de Ações Articuladas na Democratização da Gestão da Educação. 2016. Tese (Doutorado em Educação) - Faculdade de Educação, Programa de Pós-Graduação em Educação, Universidade Federal do Rio Grande do Sul, Porto Alegre, 2016.

[4] Engels, F. A Origem da família, da propriedade privada e do Estado. In: Engels, F.; Marx, K. Obras escolhidas. V.3, São Paulo: Alfa-Omega, 2008.

[5] Kosik, K. A dialética do concreto. Rio de Janeiro: Paz e Terra, 1976.

[6] Lemann. Fundação Lemann. Disponível em: <www.fundacaolemann.org.br>. Acesso em: 04 de ago. 2018.

[7] Mézsáros, I. Para além do capital. São Paulo: Boitempo; Campinas: Editora Unicamp, 2002.

[8] Peroni, V. M. V. Implicações das Relações Público-Privadas para Democratização da Gestão. 2015. Tese (Professor Titular da Carreira de magistério Superior) - Faculdade de Educação, Universidade Federal do Rio Grande do Sul, Porto Alegre, 2015.

[9] Ruiz, M. J. F. Decorrências da Relação Público-Privado para a Política e Gestão Escolar. Relatório de Pósdoutorado. Universidade Federal do Rio Grande do Sul, Porto Alegre, 2017.

[10] Sanfelice, J. L. Políticas sociais: excertos. In: Deitos, R. A.; Rodrigues, R. M. (Orgs.). Estado, desenvolvimento, democracia e políticas sociais. Cascavel: Edunioeste, 2006, p. 53-65.

[11] Thompson, E. P. A miséria da teoria ou um planetário de erros: uma crítica ao pensamento de Althusser. Rio de janeiro: Zahar Editores, 1981.

[12] Vieira, E. O Estado e a Sociedade Civil perante o ECA e a LOAS. Serviço Social e Sociedade: São Paulo, n.o 56, p.9-23, 1998.

[13] Wood, E. M. Democracia contra o capitalismo: a renovação do materialismo histórico. São Paulo: Boitempo, 2003.

[14] ___ O Império do capital. São Paulo: Boitempo, 2014. 


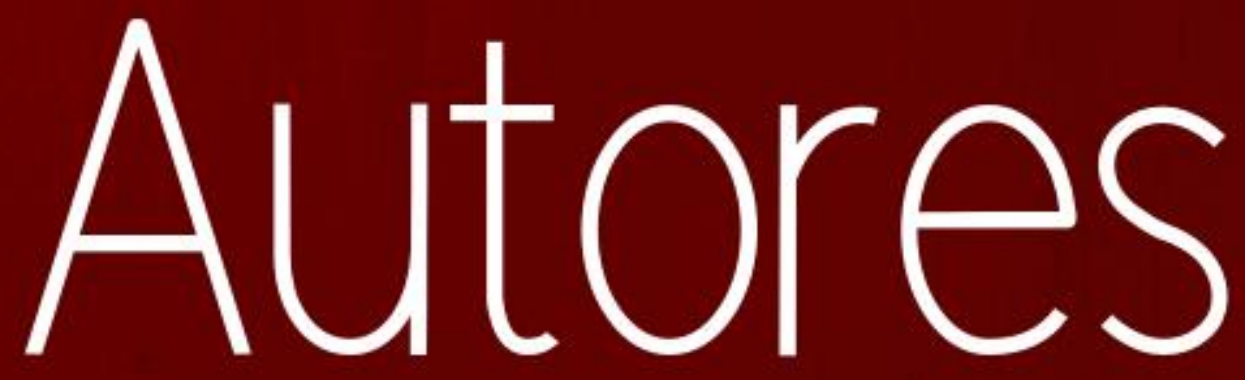




\section{ADRIÉTT DE LUNA SILVINO MARINHO}

Graduada em Pedagogia pela Universidade Federal de Pernambuco - UFPE, Especialista em Psicopedagogia -Faculdade Escritor Osman da Costa Lins - FACOL. Mestre em Psicologia Cognitiva UFPE. Atua como técnica pedagógica dos Anos Iniciais do ensino Fundamental na Prefeitura Municipal do Moreno, é professora dos Anos Iniciais no Município de Jaboatão dos Guararapes, atua na formação de professores da Educação Infantil aos Anos Iniciais do Ensino Fundamental nas redes pública e privada. Orienta trabalhos de conclusão de curso (TCC) de estudantes de Pedagogia e outras Licenciaturas.

\section{ALANE DELMONDES NÓBREGA}

Estudante de Pedagogia pela Universidade Estadual do Ceará - UECE, Bolsista do Programa Institucional de. Bolsas de Iniciação à Docência - PIBID, Inglês Intermediário, Italiano Básico e Libras Básico.

\section{ALICE MARIA CORRÊA MEDINA}

Doutora em Ciências as Saúde: Universidade de Brasília (UnB) - Pós-doutorado em Ciências Sociais: Pontifícia Universidade Católica de São Paulo (PUCSP). Professora Adjunta da Faculdade de Educação Física (FEF) da Universidade de Brasília (UnB)

\section{ANA LÚCIA BARROS DE ANDRADE}

Mestrado em Ciências do Ambiente e Sustentabilidade na Amazônia - PPGCASA/UFAM; Graduada em Licenciatura Plena em Ciências Bilógicas - ICB - UFAM. Desenvolve atividades em Ensino, Pesquisa e Extensão pela Faculdade de Tecnologia-Laboratório de Saneamento-UFAM. Formadora da Divisão de Desenvolvimento Profissional do Magistério - DDPM/SEMED e atualmente Redatora Formadora da BNCC e Referencial Curricular Amazonense-RCA.

\section{ANA MARIA FREITAS DIAS LIMA}

Graduada em PEDAGOGIA pela Fundação Universidade do Tocantins (2002).Pós-graduação : Docência do Ensino Superior-FAPAF. Orientação Educacional - Universidade Salgado de OliveiraUniverso, Gestão Pública Municipal- Universidade Federal do Tocantins- UFT. professora da educação básica - cargo -Orientadora Educacional na Escola Comunitária de Augustinópolis. Tem experiência na área de Sociologia, com ênfase em Sociologia. Filosofia. Esta cursando o Mestrado Acadêmico em Educação pela Universidade Federal do Tocantins- PPGE/UFT . Membro do Grupo de Pesquisa em Rede Internacional Investigando Escolas Criativas (RIEC- TO).

\section{ANA MERCIA DANTAS DE OLIVEIRA FELIX}

Graduanda em Licenciatura em Biologia pelo Instituto Federal de Educação Ciência e Tecnologia do Rio Grande do Norte - Campus Macau-RN e Bolsista do Residência Pedagógica (CAPES).

\section{ANA PATRICIA FARIAS BORGES}

Licencianda em Química (IF Sertão). Interessada em estudos voltados para gênero, sexualidade e educação. Nas horas vagas, escritora e leitora de ficção.

\section{ANDREZA ALENCAR COLARES BOTÊLHO}

Graduanda ( $7^{\circ}$ semestre) no Curso de Licenciatura em Ciências Biológicas pela Universidade Estadual do Ceará. 


\section{ANTONIA DALVA FRANÇA CARVALHO}

Doutora em Educação, Currículo e Ensino pela Universidade Federal do Ceará-UFC/FACED, estudou a racionalidade pedagógica da ação dos professores formadores, afiliando-se, portanto, ao campo da epistemologia da pratica profissional. Mestra em Educação pela Universidade Federal do Piauí (UFPI), onde investigou o stress e o bournout em professores e Especialista em Educação Infantil pela UFC. Atualmente é Professora Associada II e integrante do corpo docente permanente do Programa de Pós-Graduação em Educação da UFPI e Presidente da Comissão Organizadora de Concursos para Docentes. Também é Avaliadora do INEP e Consultora ad hoc da Revista Brasileira de Estudos Pedagógicos (RBEP), dentre outras, e de agencias de fomento. Assumiu a função de Coordenadora de Currículo da UFPI durante um quadriênio e de Interlocutora do REUNI, foi membro do Comitê de Ética em Pesquisa Humana da UFPI, instituiu e organizou eventos científicos como o ENID, O SIMCOP, o CPAPE, o SERP, publicou livros, artigos em periódicos especializados e trabalhos em anais de eventos científicos. Coordenou o desenvolvimento de projetos tecnológicos implementando na UFPI e programas de ensino como: PROCAMPO, PARFOR, Prodocência, Ensino na Saúde e o OBEDUC. Também fundou o Pibid, o LIFE e o Residência Pedagógica, os quais coordena. Fundou o NIPEEPP (Núcleo Interdisciplinar de Pesquisa em Educação e Epistemologia da Prática Profissional), do qual é líder e desenvolve pesquisas científicas em educação na modalidade de ensino presencial e à distância, em práticas de ensino e na formação profissional de todas as áreas epistemológicas.

\section{BIANCA BEZERRA LEANDRO}

Graduanda em Licenciatura em Biologia pelo Instituto Federal de Educação Ciência e Tecnologia do Rio Grande do Norte - Campus Macau-RN e Bolsista do Residência Pedagógica (CAPES).

\section{CARLOS LEONEL DE ALENCAR}

Graduanda em História pela Universidade Regional do Cariri (URCA).

\section{CICERA SIMONE SANTOS DE FARIAS}

Graduanda em História pela Universidade Regional do Cariri (URCA). Bolsista do Programa de Residência Pedagógica- Capes (2018-2020).

\section{CRISTINA MARIA BEZERRA DE OLIVEIRA}

Prof. a Assistente da Universidade Estadual de Alagoas (UNEAL), Campus I - Arapiraca. Doutoranda em Educação pelo PPGEDU da Universidade Federal do Rio Grande do Sul (UFRGS).

\section{DANIEL PINHEIRO CAETANO DAMASCENO}

Bacharel em Ciência da Educação, Mestre e Doutor em Sociologia Política pela Universidade Estadual do Norte Fluminense Darcy Ribeiro - UENF. Atualmente é Secretário Municipal de Educação e Cultura de São João da Barra/RJ e professor da Universidade Estácio de Sá, atuando principalmente no curso de Pedagogia em disciplinas como Pesquisa e Prática em Educação e Sociologia da Educação. Atuou como professor do Instituto Superior de Educação Professor Aldo Muylaert (ISEPAM)

\section{DILMA NAZARÉ DOS ANJOS SILVA DA FONSECA}

Docente na Rede Municipal de Ensino SEMED/Manaus/AM. Graduada em Pedagogia e Especialista em Gestão, Supervisão e Orientação Educacional pelo Centro Universitário de Manaus/FAMETRO. 


\section{ELIANA CARMEM DA SILVA}

Assistente Social da Secretaria de Estado de Educação do Rio de Janeiro -Graduada em Serviço Social pela Fundação Osvaldo Aranha - Unifoa - Volta Redonda - Especialista em Sociologia Urbana pela Universidade Estadual do Rio de Janeiro - Especialista em Educação e Relações Étnico-Raciais pela Universidade Federal Fluminense. Graduada em Pedagogia pela Universidade Federal do Estado do Rio de Janeiro. Graduanda em Sociologia pela Universidade Paulista.

\section{ELISANDRA MARIA MAGALHÃES}

Formada em Letras pela Universidade Estadual do Ceará (UECE) com habilitação em Língua Portuguesa e Francesa e suas respectivas Literaturas (2001). Possui Especialização em Ensino de Literatura Brasileira (2005) e Mestrado Acadêmico em Linguística Aplicada (2014) pela mesma Universidade. Desde 2004 é professora efetiva do quadro de Ensino Básico, Técnico e Tecnológico da Universidade Federal do Ceará, lotada na Casa de Cultura Francesa. Tem experiência na área de Letras, com ênfase em Língua Francesa. Atualmente é doutora em Linguística Aplicada pelo Programa de Pós-Graduação em Linguística Aplicada da UECE e realiza pesquisas na área de formação de professores de Língua Estrangeira com base nos estudos ergonômicos e clínicos da atividade docente.

\section{EUGÊNIA CRUZ PINHEIRO}

Graduanda em História pela Universidade Regional do Cariri (URCA).

\section{EVANILDA FIGUEIREDO GONÇALVES DA SILVA}

Possui graduação em Licenciatura Plena em Ciências Biológicas pela Universidade Federal do Pará (2003). Atualmente é professora formadora - da Rede Colaborativa de Aprendizagem, da Divisão de Desenvolvimento Profissional do Magistério - DDPM/SEMED/Manaus. É especialista em Mídias na Educação atuando principalmente nos seguintes temas: ciências, tecnologia, formação de professores, comunicação, educação e aprendizagem e Mestra em Educação e Ensino de Ciências pela UEA - Universidade do Estado do Amazonas

\section{FARBÊNIA KÁTIA SANTOS DE MOURA}

Graduada em pedagogia - UECE (Universidade Estadual do Ceará). especialista em gestão educacional e coordenação pedagógica - FIVALE (Centro de Ensino de Limoeiro do Norte - CE). mestre em educação e ensino - MAIE (Mestrado Acadêmico Intercampi em Educação e Ensino) FAFIDAM (Faculdade de Filosofia Dom Aureliano Matos) / FECLESC ( Faculdade de Educação, Ciências e Letras do Sertão Central)

\section{FERNANDA LETÍCIA SOUSA LIMA}

Graduanda de Pedagogia pela Universidade Estadual do Ceará - UECE e Bolsista do Programa Institucional de. Bolsas de Iniciação à Docência - PIBID/CAPES.

\section{FRANCISCA ELIANE DA ROCHA}

Graduanda em Licenciatura em Biologia pelo Instituto Federal de Educação Ciência e Tecnologia do Rio Grande do Norte - Campus Macau-RN e Bolsista do Residência Pedagógica (CAPES).

\section{INGRID VASCONCELOS FERREIRA}

Graduanda do Curso de Pedagogia da Universidade Federal do Amazonas - UFAM, Campus Parintins, 


\section{JAKLANE NUNES RABÊLO}

Doutoranda e Mestra em Ciências da Educação pela Universidade Interamericana - PY. Graduada em Letras Vernácula, com especialidade em Linguística e Literatura Portuguesa pela Universidade do Estado da Bahia - UNEB, em História da Cultura Afro-brasileira pela Faculdade de Tecnologia e Ciências (FTC) - BA e em Metodologia da Língua Portuguesa Pela Faculdade Vasco da Gama - BA. lanerabelo@hotmail.com

\section{JEANNE BARROS LEAL DE PONTES MEDEIROS}

Possui Doutorado em Educação (2017) pela Universidade Estadual do Ceará, Mestrado em Desenvolvimento e Meio Ambiente (2004) pela Universidade Federal do Ceará, Especialização em Botânica (1995) e Graduação em Ciências Biológicas pela Universidade Federal do Ceará nas modalidades Licenciatura (1994) e Bacharelado (1995). É professora adjunta e atualmente coordena o Curso de Ciências Biológicas/ CCS da Universidade Estadual do Ceará, onde preside o Núcleo Docente Estruturante. Coordena os estágios do Curso de Licenciatura em Ciências Biológicas UAB/UECE e o Laboratório de Formação de Professores - LAFORP. Tem experiência na área de Botânica, com ênfase em Taxonomia de Criptógamas. Atua nas áreas de Formação de Professores e Currículo.

\section{JOSEFA NUNES PINHEIRO}

Professora da Universidade Regional do Cariri (URCA). Tem experiência na área de História, Democracia, Políticas Sociais e Saúde Pública, atuando principalmente nos seguintes temas: Ensino de História, Família, Saúde Pública e Descentralização. Docente Orientador do Programa de Residência Pedagógica- Capes (2018-2020).

\section{JOSSEANE ARAÚJO DA SILVA SANTOS}

Possui graduação em Letras/Português e Literaturas Portuguesa e Brasileira, pela Universidade do Tocantins (1998). Atuou no setor de aperfeiçoamento discente, como técnica em assuntos educacionais, na Diretoria e Programas Especiais em Educação da pró-reitoria de graduação da Universidade Federal do Tocantins (2007-2009). Trabalhou no Centro de Idiomas do centro universitário de Palmas/UFT (2009-2011) e na Diretoria de Assuntos Internacionais da UFT (2011-2015). Atualmente trabalha na Pró-reitoria de graduação no Programa Nacional de Formação de Professores, Programa de Formação Docente Continuada, Programa de Educação Tutorial e Mobilidade Acadêmica e é mestranda em educação pelo Programa de Mestrado em Educação na UFT e membro da Rede Internacional de Escolas Criativas - RIEC.

\section{LILIAN GAMA DA SILVA PÓVOA}

Mestranda em Educação pela Universidade Federal do Tocantins (UFT). Pós-graduada em Docência do Ensino Superior; Pós-Graduada em Gestão Escolar (Administração e Supervisão) pela Universidade Estadual do Piauí (2005); Possui Licenciatura Plena em Pedagogia pela Universidade Estadual do Piauí (2000).Profissional Coaching pelo Instituto Aurum. É funcionária do Tribunal de Justiça do Tocantins atuando como Supervisora Pedagógica e Secretária Acadêmica da Escola Superior da Magistratura Tocantinense (ESMAT). Atuou como professora do Curso de Pedagogia da Fundação Universidade do Tocantins (UNITINS) / Universidade Universidade Aberta do Brasil (UAB). Atuou como coordenadora de Projetos da FADES - Faculdade Para o Desenvolvimento do Sudeste Tocantinense - ; Coordenadora do Ensino Fundamental e Médio da Diretoria Regional de Ensino de Dianópolis -TO ; Analista de Gestão Pedagógica da Defensoria Pública; Professora de Pós Graduação do INAPS (Instituto Nacional de Pós Graduação e Ensino Superior); Professora da FADES - Faculdade Para o Desenvolvimento do Sudeste Tocantinense; Professora avaliadora de bancas de Monografia da FAEL (Faculdade Educacional da Lapa). 


\section{LUCAS DE PÁDUA DA SILVA MAIA}

Graduando $\left(7^{\circ}\right.$ semestre) no Curso de Licenciatura em Ciências Biológicas pela Universidade Estadual do Ceará.

\section{LUCIANA PEIXOTO BESSA}

Possui graduação em Letras - Português/ Inglês pela Universidade Federal do Ceará (2003). É especialista em Linguística Aplicada ao Ensino de Língua Inglesa (2007). É mestre em Linguística Aplicada pela Universidade Estadual do Ceará (2018). Desde 2010, é professora efetiva da rede estadual cearense, lotada na EEM Governador Adauto Bezerra. Possui experiência na área de Letras, com ênfase no ensino e na aprendizagem de Línguas Inglesa e Portuguesa. É doutoranda do Programa de Pós-Graduação em Linguística Aplicada da Universidade Estadual do Ceará (UECE) e realiza pesquisas com ênfase na atividade docente, com base nos estudos da Ergonomia da Atividade e da Clínica da Atividade.

\section{LUCILENE PACHECO SANTOS}

LUCILENE PACHECO SANTOS - é Graduada e Pedagogia e Mestre em Educação pela Universidade Federal do Amazonas. Desenvolve pesquisas sobre Formação Continuada, Educação Escolar Indígena e Avaliações do Desempenho do Estudante (ADE) e O Sistema Nacional de Avaliação da Educação Básica (Saeb). Atua na Formação Continuada para Professores(as) da Educação Básica Anos Iniciais área urbana, rural/ribeirinha, Professores(as) das Escolas e Centro Culturais Indígenas da Secretaria Municipal de Educação (SEMED) do Município de Manaus/AM.

\section{LUZIA ALVES DE CARVALHO}

Doutorado em Sociología pela Universidad Pontificia de Salamanca, revalidado pela Universidade Federal de Pernambuco. Mestrado em Educação pela Pontifícia Universidade Católica do Rio de Janeiro. Especialização em Psicopedagogia na Educação pela Universidade Estácio de Sá. Especialização em Metodologia do Ensino Superior pela PUC-Minas. Licenciatura em Pedagogia pela Faculdade Dom Bosco de Filosofia Ciências e Letras. Atualmente é diretora do Instituto Superior de Educação do ISECENSA, Coordenadora do Curso de Pedagogia e Diretora Acadêmica do Centro Educacional Nossa Senhora Auxiliadora, ambos em Campos dos Goytacazes/RJ.

\section{MARIA DAS GRAÇAS PEREIRA SOARES}

Doutora em Educação e Professora de Estágio Supervisionado do Curso de Pedagogia da Universidade Federal do Amazonas (ICSEZ/UFAM). Campus Universitátio, Parintins (AM)

\section{MARIA DO SOCORRO TAVARES CAVALCANTE}

Professora pedagoga do Instituto Federal de Educação, Ciências e Tecnologia do Sertão Pernambucano - IF - SERTÃO - PE Campus Petrolina. Tem experiência na área de Educação, com ênfase em formação docente, atuando nos seguintes temas: projetos didáticos, tecnologia e educação, métodos e técnicas de ensino, gestão escolar, autorregulação de aprendizagem e metacognição. Especialista em Metodologia da Pesquisa Científica (UPE), Psicopedagogia (IBPEX) e Direito Educacional (PUC Minas). Mestrado em Psicologia (UNIVASF). Doutoranda em Agroecologia e Desenvolvimento Territorial (UNIVASF)

\section{MARIA JOSÉ DE PINHO}

Possui graduação em História e graduação em Pedagogia. Mestrado em Educação pela Universidade Federal de Pernambuco. Doutorado em Educação e Currículo pela Pontifícia Universidade Católica de São Paulo e Pós - Doutorado em Educação pela Universidade do AlgarvePortugal. É professora Associado e Bolsista Produtividade do CNPq categoria 2. Tem experiência na área de Educação, com ênfase em Política Educacional, atuando principalmente nos seguintes temas: formação de professores, política educacional, profissionalização docente, avaliação 
institucional, Metodologia de Pesquisa; Estudos Contemporâneos. Avaliadora do Sistema Nacional de Avaliação da Educação Superior do INEP /MEC.É professora na graduação Curso de Jornalismo, no Programa de Pós-Graduação Mestrado e Doutorado em Ensino de Língua e Literatura. Docente. Também é professora no Programa de Pós-Graduação Mestrado em Educação a partir de 2012. É membro da Rede Internacional de Escolas Criativas: construindo a escola do século XXI (RIEC Coord. UB/Espanha). Orienta mestrado e doutorado sobre formação de professores; práticas educativas;política educacional; teoria da complexidade. Desenvolve pesquisa sobre escolas criativas; educação e formação de professor.

\section{NATALIANA DOS SANTOS OLIVEIRA}

Graduanda em História pela Universidade Regional do Cariri (URCA).

\section{PATRÍCIA CARLA VIEIRA ROMÃO BOTELHO}

Mestra em Educação em Ciências e Matemática pelo PPGEduCIMAT da UFRRJ (2019). Pósgraduanda em Gestão Escolar - Orientação e Supervisão pela Faculdade de Educação São Luís (2019-2020). Especialista em Ensino de Ciências e Matemática pelo IFRJ - Campus Volta Redonda (2016). Possui Licenciatura Plena em Ciências Biológicas pela FERP/ UGB (2001) Volta Redonda RJ.Atualmente é professora concursada do Ensino Fundamental II na Prefeitura Municipal de Volta Redonda e do Ensino Médio e Técnico em Meio Ambiente na Rede Estadual de Ensino do Rio de Janeiro, é Coordenadora na rede particular de ensino e atua como Mediadora Presencial da graduação em Biologia pela UFRJ/ Polo CEDERJ - VRE e como Orientadora de TCC da graduação em Pedagogia pela UNIRio/ Polo CEDERJ - VRE. Tem experiência em sala de aula, Tutoria em Educação à Distância, Laboratório Escolar e na área de Zoologia, com base em seu estágio no Zoológico Municipal de Volta Redonda - RJ no qual realizou estudos de Ecologia de Animais Silvestres e atuou em projetos de Educação Ambiental para estudantes e para o público em geral. É Mãe Escoteira, membro do Conselho Fiscal no 53ํㅡㅁ Grupo Escoteiro Vigilante da Acácia.

\section{PAULA IVANI MEDEIROS DOS SANTOS}

Professora do Instituto Federal de Educação Ciência e Tecnologia do Rio Grande do Norte - Campus Macau-RN. Bióloga_Mestre em Bioecologia Aquática (Toxicologia aquática). Doutora em Bioquímica e Biologia Molecula

\section{PAULO ALVES XAVIER DA SILVA}

Graduando em Licenciatura em Química pelo Instituto Federal de Ciência e Tecnologia do Sertão Pernambucano. Atualmente bolsista do Programa Institucional de Bolsa de Iniciação à Docência (PIBID) e estagiário da Companhia Pernambucana de Saneamento (Compesa) realizando análises físico-químicas e microbiológicas no controle de tratamento de efluentes.

\section{POLIANA ALVES DOS SANTOS}

Graduada em Pedagogia, pela Universidade Federal do Piauí (UFPI) - Campus Universitário Ministro Petrônio Portella - Teresina. Pesquisadora no âmbito da formação inicial de professores, com referências de pesquisas sobre o Saberes Docentes, Formação do Pedagogo na Modalidade Presencial e na EaD(Pelo PIBIC/CNPq/UFPI). Pesquisa realizada no campo da Educação Especial sobre Autismo, e o Lúdico na Educação Infantil.

\section{ROZANIA MARIA ALVES DE MORAES}

Professora Associada do Curso de Letras e do Programa de Pós-Graduação em Linguística Aplicada (PosLA) da Universidade Estadual do Ceará Possui mestrado em Letras, pela Universidade Estadual do Ceará, doutorado em Ciências da Linguagem, pela Universidade Grenoble III (2005) e pós-doutorado em Ciências da Educação - Ergonomia da Atividade de Profissionais da Educação (2012) pela Universidade Aix-Marseille. Fundadora e coordenadora, desde 2010, do Grupo de 
Estudos LIFT (Linguagem, Formação e Trabalho), realizando estudos sobre a análise da atividade profissional (sobretudo a atividade docente) sustentados nos princípios da Ergonomia da Atividade, da Clínica da Atividade e da Análise Dialógica do Discurso.

\section{SCHEILER FAGUNDES CARVALHO}

Prof. a da Educação Básica do Estado do Rio Grande do Sul, Gravataí/RS. Mestranda em Educação pelo PPGEDU da Universidade Federal do Rio Grande do Sul (UFRGS).

\section{TALITA DA SILVA ERNESTO}

Doutoranda em Cognição e Linguagem pela Uenf. Mestre em Cognição e Linguagem pela Uenf. Mestre em Ciência da Educação pela Universidade Autônoma de Assunção. Psicopedagoga Institucional e Empresarial. Pedagoga.

\section{TAMIRES CRISTINA RIBEIRO SILVA}

Graduada em Pedagogia pela Faintivisa. Atua como Coordenadora dos Anos Iniciais do ensino Fundamental na Prefeitura Municipal do Moreno e é professora dos Anos Iniciais no Município de Jaboatão dos Guararapes. Atua na formação de professores dos Anos Iniciais do Ensino Fundamental.

\section{TÂNIA SERRA AZUL MACHADO BEZERRA}

Professora Adjunta da Universidade Estadual do Ceará. Possui graduação em Pedagogia pela Universidade Federal do Ceará (2004); Mestrado em Educação Brasileira pela Universidade Federal do Ceará (2007) e Doutorado em Educação Brasileira pela Universidade Federal do Ceará (2011). Pós-doutorado em Educação pela Universidade do Porto, vinculada a Faculdade de Psicologia e Ciências da Educação - FPCEUP, no âmbito de Formação de Professores. Pesquisadora do EIP/UP. Tem experiência na área de Educação e Formação de Professores, no setor práticas de ensino. Como pesquisadora atua nas seguintes linhas: Trabalho e Educação; Práxis Docente; Economia, Política, Sociabilidade e Educação; Também desenvolve pesquisas na área de Educação Infantil e Formação Docente.

\section{VINICIUS CARVALHO PEREIRA}

Graduando $\left(7^{\circ}\right.$ semestre) no Curso de Licenciatura em Ciências Biológicas pela Universidade Estadual do Ceará.

\section{WELLYNGTON CHAVES MONTEIRO DA SILVA}

Prof. Assistente da Universidade Estadual de Alagoas (UNEAL), Campus VI - Maceió. Doutorando em Educação pelo PPGEDU da Universidade Federal do Rio Grande do Sul (UFRGS).

\section{WESCLEY BATISTA LOPES}

Professor de francês do Instituto de Educação e Cultura - Pense Idiomas. Possui graduação em Letras (Francês) pela Universidade Estadual do Ceará (2015) e mestrado em Linguística Aplicada (2017) pelo Programa de Pós-Graduação em Linguística Aplicada (PosLA) da Universidade Estadual do Ceará, com a dissertação intitulada "Prescrições e instrumentos na aula de civilização: análise da atividade docente de estagiários de FLE" - pesquisa fomentada pela Fundação Cearense de Apoio ao Desenvolvimento Científico e Tecnológico (Funcap). Atualmente é graduando do curso de Letras (Português - Francês) da Universidade Federal do Ceará e membro do Grupo de Estudos LIFT (Linguagem, Formação e Trabalho). 
Agência Brasileira do ISBN ISBN 978-85-7042-224-8

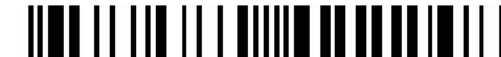

|| $\mid$

- |||||||||||| $\mid$

$9{ }_{788570}{ }_{422248}$ 